SØREN LANGAGER, OLE ROBENHAGEN, ANNEMARIE HØJMARK OG PETER ALLERUP

\title{
SOCIALPFADAGOGIK I BOTILBUD FOR VOKSNE MED VARIG NEDSAT PSYKISK FUNKTIONSEVNE
}

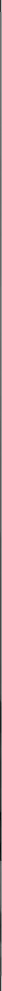





\section{Socialpædagogik i botilbud for voksne med varig nedsat psykisk funktionsevne}

Søren Langager, Ole Robenhagen, Annemarie Højmark og Peter Allerup 
Titel: Socialpædagogik i botilbud for voksne med varig nedsat psykisk funktionsevne

Forfattere: Søren Langager, Ole Robenhagen, Annemarie Højmark og Peter Allerup

(C) 2009 Forfatterne og DPU, Aarhus Universitet

1. udgave

Omslag og grafisk design: Knud Holt Nielsen

Kopiering tilladt med tydelig kildeangivelse

ISBN 978-87-7430-061-8; 978-87-7507-331-3 (elektronisk udgave)

DOI 10.7146/aul.53.42

Publikationen er udgivet i serien 'Socialpædagogisk faglighed og voksne med psykisk/fysisk handicap' (serieredaktør: Søren Langager) under DPU's Forskningsprogram 'Social- og specialpædagogik i inkluderende perspektiv'. 


\section{I ndhold}

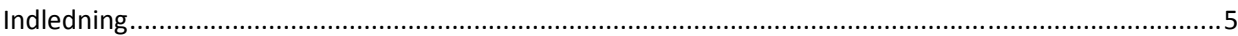

Kapitel 1. Botilbud, velfærdspolitik og socialpædagogiske problemstillinger .......................................10

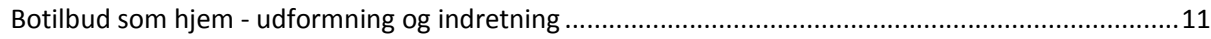

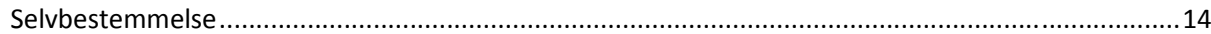

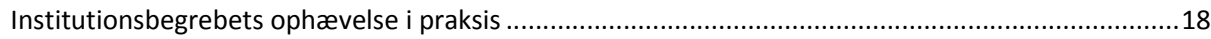

Den faglige selvforståelse, trivsel og opkvalificeringsstrategier .......................................................19

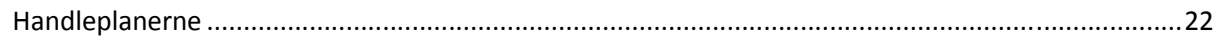

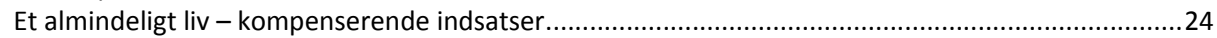

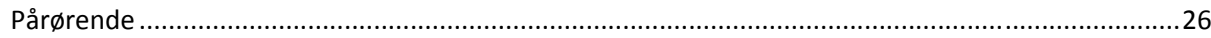

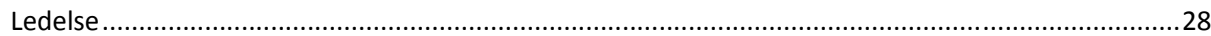

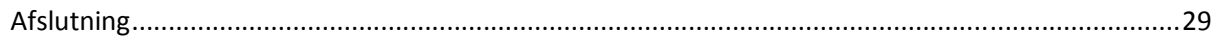

Kapitel 2. Medarbejderprofiler og medarbejdernes overordnede syn på arbejdet................................31

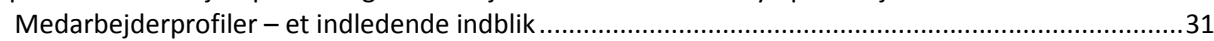

Arbejdspladserne og medarbejdernes karakteristik af beboerne/brugerne........................................36

Medarbejdernes overordnede syn på arbejdet. 'Tilfredshedsbarometer' og oplevelse af

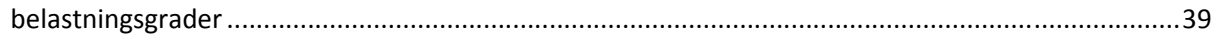

Kapitel 3. Det gode liv i egen bolig, etiske dilemmaer og vanskelige beboere. Myte eller fakta? .............43

Pejlemærker på 'et godt liv' i egen bolig ....................................................................................43

Synspunkter på det daglige arbejde, herunder etiske dilemmaer, vanskelige beboere og samarbejdet

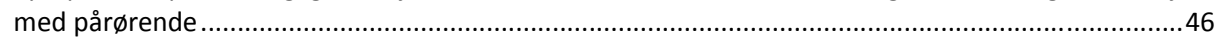

Kapitel 4. Kontaktsomhed - en antropologisk feltberetning fra et bo- og dagtilbud ..............................59

"Ja, for jeg skal jo ikke mangle noget" siger Oline ..........................................................................61

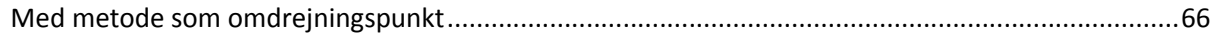

På 'hjemmedagen' klipper vi negle, renser $\emptyset$ rer og bliver vejet ..................................................... 70

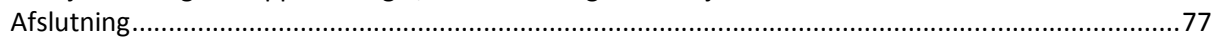

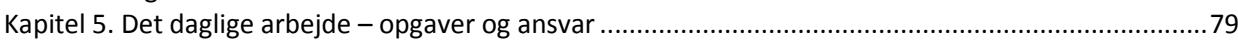

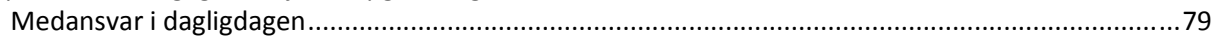

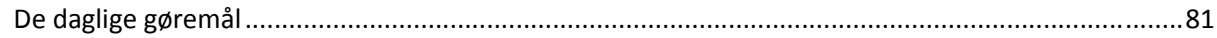

Oplevelse af vanskelige omsorgsopgaver i det daglige arbejde? ...................................................84

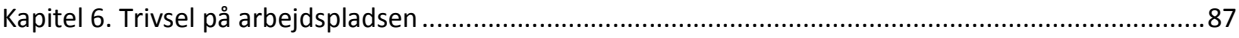

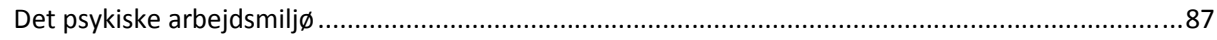

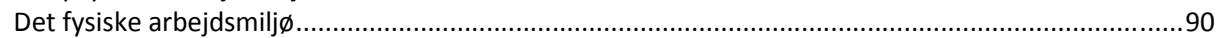

Trivsel, men også ønske om forandring i arbejdet ...........................................................................91

Kapitel 7. Arbejdsvilkår, kompetenceudvikling og medarbejdernes uddannelses- og erfaringsbaggrund 94

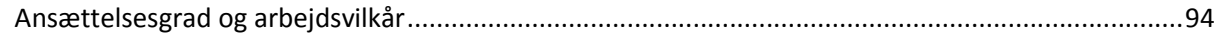

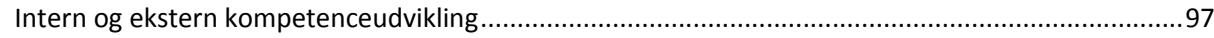

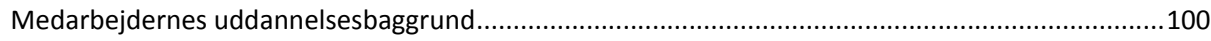

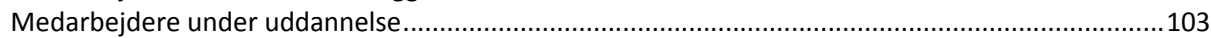

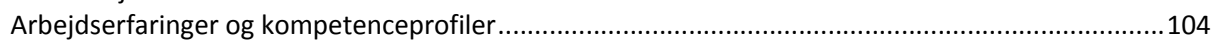

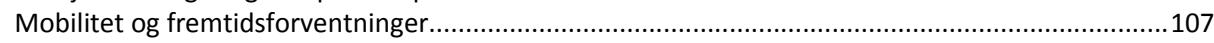

Kapitel 8. Synspunkter på fagligt udviklingsarbejde, ledelse og organisation......................................109

Prioritering af faglige udviklingsinitiativer i botilbud................................................................109

Medarbejdernes vurdering af ledelse og organisation i botilbud ..................................................111

Synspunkter på vigtige fokusområder i indsatsen for voksne med psykisk handicap.......................114

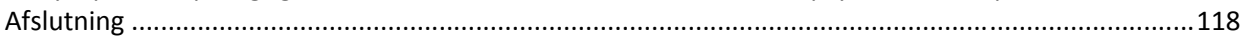

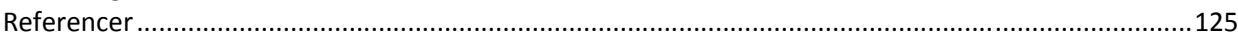

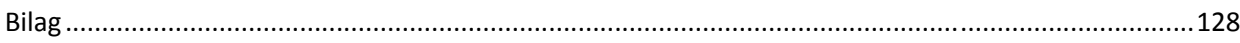

Bilag 1. Metoder og analyser i forbindelse med sp $\varnothing$ rgeskemadataindsamlingen ............................129

Bilag 2. Om det antropologiske feltstudie .............................................................................. 138

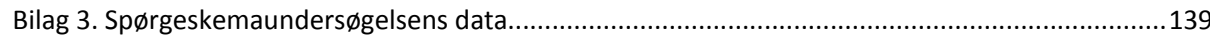




\section{I ndledning}

"Selvom institutionsbegrebet for voksne ikke længere findes i lovgivningen, bliver botilbud ofte omtalt som institutioner. Det hænger sammen med, at det i praksis har været vanskeligt at ændre tilbuddenes karakter, herunder personalets og beboernes samt det omkringliggende samfunds grundlæggende opfattelse af botilbud som institutioner. Denne opfattelse afspejles derfor i kulturen i mange botilbud." (Socialministeriet 2007:4).

Således $\mid \varnothing d$ en af udmeldingerne fra en arbejdsgruppe nedsat af Socialministeriet i kølvandet på de sager om omsorgssvigt, der efter TV2's udsendelse "Er du 'åndssvag'?" i februar 2007 rullede i medierne. Arbejdsgruppen kom med en række anbefalinger til kompetenceudvikling og fagligt kvalitetsløft inden for bo- og dagtilbud for voksne med varig fysisk eller psykisk nedsat funktionsevne, og rapporten 'Veje til et godt liv i egen bolig. Fokus på etik, værdigrundlag og kompetenceudvikling i botilbud for mennesker med handicap og sindslidelser m.fl.' (Socialministeriet 2007) blev et af baggrundspapirerne for det udbud på foreløbig 24 mio. kr., som Indenrigs- og Socialministeriet via satspuljemidler i efteråret 2009 udmeldte til praksisforankret fagligt udviklingsarbejde i botilbud. Udbuddets overordnede formål er "at skabe bedre livsvilkår for beboere $i$ botilbud gennem kvalitets- og kompetenceudviklingsinitiativer målrettet botilbuddenes medarbejdere og ledelse." (Indenrigs- og Socialministeriet 2009).

Publikationen 'Socialpædagogik i botilbud for voksne med varig nedsat psykisk funktionsevne ${ }^{\prime 1}$ kan forhåbentligt - sammen med de øvrige 4 udgivne publikationer i DPU's nye serie 'Socialpædagogisk faglighed og voksne med psykisk/fysisk handicap' ${ }^{2}$ - være til inspiration i det faglige udviklingsarbejde i bo- og dagtilbud rundt om i landet i de kommende år.

Selvom udgivelsestidspunktet må siges at være 'timet', er det tilfældigt heldigt, for tilblivelsen af undersøgelsen af pædagoger og omsorgsmedhjælpere i botilbud har en

\footnotetext{
${ }^{1}$ Der er mange betegnelser for målgruppen i spil, og hvad det mest 'fagpolitisk korrekte' er, varierer. Den juridiske betegnelse 'voksne med varig nedsat psykisk funktionsevne', 'voksne udviklingshæmmede' (som anvendes i Indenrigs- og Socialministeriets puljebeskrivelse), 'voksne med udviklingshæmning' (som har været hyppig de seneste år) eller 'voksne psykisk handicappede' (som er gængs i international handicapforskning). I denne og de øvrige publikationer (se note 2 ) har vi valgt at anvende forskellige betegnelser om ikke i flæng, så dog lidt tilfældigt afhængig af den kontekst, målgruppen optræder i.

2 * Hur (2009) Frigørelsens magt - pædagogiske roller i relation til frie, udviklingshæmmede voksne,

* Højmark (2009). Om tilsætning og opfindsomhed - en pædagogisk antropologisk undersøgelse om begrundelser i socialpædagogisk arbejde med voksne med udviklingshæmning i botilbud.

* Kofod og Jensen (2009). Organisationsudvikling og socialpædagogisk praksis i bo- og dagtilbud for voksne udviklingshæmmede.

* Robenhagen, Langager, Højmark og Allerup (2009). Den daglige forskel - omsorgsmedhjælpere i bo- og dagtilbud for voksne med varig nedsat fysisk eller psykisk funktionsevne.

Publikationerne kan downloades fra www.dpu.dk/ssip/ebog
} 
langt historie bag sig. Så lang, at projektet startede før navne som Strandvænget, Bostedet Sjælør, Tokanten m.fl. blev kendt i den brede offentlighed.

I efteråret 2006 henvendte FOA's (Fag og Arbejde) Pædagogiske Sektion sig til DPU med ønsket om en kortlægning af arbejdsvilkår og arbejdsmiljø for FOA-organiserede omsorgsmedhjælpere ansat i bo- og dagtilbud for voksne med psykisk eller fysisk handicap. Et arbejdsområde, hvorom der stort set ikke findes forskningsbaseret empirisk viden. Henvendelsen byggede på tidligere erfaringer med samarbejder mellem FOA og DPU om kortlægning af arbejdsvilkår mv. for pædagogmedhjælpere i daginstitutioner og SFO/fritidshjem ${ }^{3}$.

Da DPU har socialpædagogik som et højt prioriteret forskningsområde via etableringen af forskningsprogrammet SSIP (Social- og specialpædagogik i inkluderende perspektiv), som er forskningsenheden bag projektet, udvidedes aftalen til ikke kun at omfatte FOA-organiserede omsorgsmedhjælpere på landsplan, men også en 'totalunders $\varnothing$ gelse' af pædagoger og omsorgsmedhjælpere ansat i botilbud inden for et afgrænset område, Københavns Kommune ${ }^{4}$.

Projekt 'Socialpædagogik og bo- og dagtilbud for voksne udviklingshæmmede' med de to delprojekter - et om FOA-organiserede omsorgsmedhjælpere på landsplan og 'Københavnerundersøgelsen' med deltagelse af pædagoger og omsorgsmedhjælpere igangsattes, og efter forberedende interview med 'garvede' medarbejdere i bo- og dagtilbud og konstruktion af et spørgeskema som grundlag for det empiriske fokus, var kortene lagt tilrette i efteråret 2007.

På det tidspunkt var området på grund af de mange mediesager og påbegyndte kommunalt initierede akutundersøgelser så 'overophedet', at vi besluttede at udskyde den praktiske gennemførsel af selve spørgeskemaundersøgelserne, idet formålet hermed ikke er at 'gå efter sensationerne', men at bidrage med solid empirisk forankret viden om det daglige arbejde i bo- og dagtilbud for voksne med udviklingshæmning.

Undersøgelsen lå således 'brak' til 2008, og i april gennemførtes spørgeskemaunders $\varnothing$ gelsen rettet mod omsorgsmedhjælpere på landsplan, mens unders $\varnothing$ gelsen blandt pædagoger og omsorgsmedhjælpere løb af stablen i september 2008.

Publikationen her angår alene 'Københavnerundersøgelsen's, og den omfatter tre hoveddatakilder. Først og fremmest en omfattende kvantitativ spørgeskemaunders $\varnothing$ gelse

\footnotetext{
${ }^{3}$ Bryderup, Langager og Robenhagen (2000) og Allerup, Langager og Robenhagen (2004). Projekterne er tilbage fra den tid, hvor FOA Pædagogisk Sektion var den selvstændige fagforening PMF (Pædagogisk Medhjælper Forbund), og 'DPU- forskningsgruppen' var forankret i DPI (Danmarks Pædagogiske Institut) og Danmarks Pædagogiske Universitet.

4 'Københavnerundersøgelsen' er koncentreret om botilbud til voksne med psykisk udviklingshæmning. Tilbud primært rettet mod fysisk handicappede er derfor ikke medtaget.

${ }^{5}$ Den landdækkende omsorgsmedhjælperunders $\varnothing$ gelse er rapporteret i Robenhagen, Langager, Højmark og Allerup (2009).
} 
med deltagelse af 245 pædagoger og omsorgsmedhjælpere og 15 ledere ansat i bo- og dagtilbud i Københavns Kommune ${ }^{6}$, suppleret med kvalitative antropologiske feltstudier i et bo- og dagtilbud, og endelig dokumentlæsning med gennemgang og analyse af centrale rapporter og 'policy-papers' inden for området efter Servicelovens ikrafttræden i 1998.

Spørgeskemaundersøgelsens fokus er det daglige arbejde i botilbud for voksne udviklingshæmmede. Hvilke arbejdsopgaver har de ansatte pædagoger og omsorgsmedhjælpere i praksis, hvilke rutiner er der på bostedet, hvordan opleves det fysiske og psykiske arbejdsmiljø, og hvilke erfaringer har medarbejderne med pædagogiske udfordringer i form af 'vanskelige beboere', 'etiske dilemmaer', 'krævende pårørende' med videre.

Undersøgelsen giver også en detaljeret beskrivelse af de to medarbejdergrupper, pædagoger og omsorgsmedhjælpere samlet og hver for sig. Hvem er de, set ud fra parametre som alder, køn, uddannelsesbaggrund, anciennitet inden for området og erfaringer fra andre pædagogiske arbejdsområder.

Endelig angår en række spørgsmål mere vurderende og tolkende sider af den socialpædagogiske faglighed i botilbud. Hvilke synspunkter og holdninger har medarbejderne til 'gode indsatser' for beboerne/brugerne, og hvilke faglige udviklingsveje og kompetenceudviklingsområder mener de især bør prioriteres højt?

En intention om at kortlægge de mere 'uspektakulære' sider af det socialpædagogiske arbejde i botilbud for voksne med udviklingshæmning, som kan bidrage med solid empirisk viden om og indsigt i de daglige rutiner i botilbuddene og de faglige kvalifikationer, kompetencer og erfaringer, medarbejderne repræsenterer. Ikke 'kun' som samlet medarbejdergruppe, men undervejs differentieret $\mathrm{i}$ komparative analyser mellem uddannede pædagoger og omsorgsmedhjælpere typisk uden en mellemlang videregående pædagoguddannelse.

Kortlægningen og analysen af socialpædagogisk faglighed i botilbud for voksne udviklingshæmmede vil blandt andet undersøge om det indledningsvis rejste problem om at "det i praksis har været vanskeligt at ændre tilbuddenes karakter, herunder personalets ... grundlæggende opfattelse af botilbud som institutioner" holder stik, og rapporten er disponeret i otte kapitler.

\footnotetext{
${ }^{6}$ Svarprocenten er ikke oppe på de 'magiske' 85 \%, og således ikke i statistisk forstand repræsentativ, men indtrykket er, at der har været tale om en - tiden og medieophedningen taget i betragtning - en acceptabel svarprocent på omkring $60 \%$. Her kan sammenlignes med den unders $\varnothing$ gelse, som Københavns Kommune iværksatte i starten af 2008 (og som var medvirkende årsag til, at DPU undersøgelsen blev sat på 'stand by' i en længere periode, idet formålene nok var forskellige, men begge inkluderer spørgeskemaunders $\varnothing$ gelse), trods adskillige svarrykkere ikke nåede over en svarprocent på 36 blandt medarbejdere i de involverede botilbud i Københavns Kommune (Nirás Konsulenterne 2008). Se bilag 1 for præsentation og analyse af DPU undersøgelsens datagrundlag.
} 
Kapitel 1 er dokumentgennemgang og analyse af centrale rapporter og 'policypapers' gennem de sidste ti år. Hvad er tematiseret, beskrevet og analyseret siden 'Lov om social service' trådte i kraft i 1998 og ophævede institutionsbegrebet og 'pålagde' alle borgere at være udviklingsindstillede og hermed nydefinerede de socialpædagogiske indsatser som professionel støtte hertil uden at give køb på varetagelsen af de basale omsorgsfunktioner.

Herefter følger kapitel 2, som introducerer spørgeskemaundersøgelsen og tegner en overordnet profil af de deltagende pædagoger og omsorgsmedhjælpere. Samtidig præsenteres nogle af undersøgelsens overordnede 'konklusioner', som i de følgende kapitler uddybes og nuanceres.

Kapitel 3 tager fat i nogle af 'de store spørgsmål' og inddrager især spørgsmål af vurderende tilsnit, idet de deltagende pædagoger og omsorgsmedhjælpere bliver bedt om at tage stilling til en række spørgsmål omkring synspunkter på det daglige arbejde, etiske dilemmaer, 'vanskelige beboere', og pejlinger på 'det gode liv' i botilbud.

I kapitel 4 skiftes synsvinkel og datagrundlag, idet målet her er at se på dagligdagen i bosteder med 'den udefrakommendes' øjne. Et antropologisk feltstudie fra et bo- og dagtilbud, hvor der gives bud på, hvordan samspillet mellem beboere og pædagogiske medarbejdere fungerer, og hvilke kommunikations- og interaktionsformer, der ser ud til at være i spil i dagligdagen i bo- og dagtilbud.

Så følger kapitel 5 og 6, der giver et detaljèret indblik i de daglige arbejdsopgaver og hvorvidt der er situationer, hvor det pædagogiske omsorgsarbejde især opleves vanskeligt? Spørgsmål herom kædes sammen med det generelle billede af medarbejdernes trivsel på arbejdspladsen, såvel med hensyn til det fysiske som det psykiske arbejdsmiljø.

I kapitel 7 tages tråden fra kapitel 2 op igen. I dette kapitel udfoldes en detaljeret karakteristik af medarbejdernes ansættelsesvilkår, uddannelsesmæssige og erfaringsmæssige baggrunde og ikke mindst i hvilket omfang, de løbende indgår i faglige kompetenceudviklingskurser mv. i det botilbud, de er ansat i.

Mens især kapitel 7 er meget 'datatungt' med en række faktuelle opgørelser, vendes blikket i det afsluttende kapitel 8 på ny mod mere holdningsprægede spørgsmål, idet der her tegnes et billede af, hvor medarbejderne især mener, der er grund til at vægte fagligt og organisatorisk udviklingsarbejde i botilbud for voksne med udviklingshæmning.

Endelig følger en kortere afslutning og tre bilag med beskrivelser og overvejelser over spørgeskemaundersøgelsens datagrundlag og det antropologiske feltstudie og som bilag 3 alle de grunddata, som spørgeskemaundersøgelsen rummer. Undervejs i teksten er der en del henvisninger til dette bilag, idet kun dele af materialet er inddraget $\mathrm{i}$ 
de enkelte kapitler, og her i flere tilfælde i bearbejdet form. Med bilag 3 er det muligt for interesserede at dykke ned i de mange data og uddrage andre dele heraf, end vi har valgt undervejs.

Bortset fra kapitel 1 og 4 er kapitlerne 'tal-tunge' med ind imellem lange tabeller og mange procenttal, som hører den kvantitativt funderede spørgeskemagenre til. Vi har valgt at lade tallene stå i deres 'rene form' og ikke forsøge at 'pædagogisere' med fikse, men også ofte noget uoverskuelige grafiske fremstillinger.

Til gengæld har vi arrangeret datamaterialet tematisk, således at alle kapitler kan læses hver for sig og i vilkårlig rækkefølge alt efter læserens særlige interesser. Og mens især kapitlerne 5, 6 og 7 er præget af mange tabeller, er de i kapitlerne 2, 3 og 8 ikke (helt) så dominerende. Samtidig er fremstillingen så vidt muligt i en form, hvor man så at sige 'kan læse henover' selve tabellerne, idet vi i den omgivende tekst trækker de vigtigste data frem integreret i teksten.

Tilbage er - her indledningsvist - at sige tak til FOA for $\varnothing$ konomisk st $\varnothing$ tte og den tekniske support fra LFS og FOA med at finde frem til og formidle spørgeskemaer mv. til medarbejdere og ledere, og så naturligvis en stor tak til de 15 ledere og 245 pædagoger og omsorgsmedhjælpere, der afsatte den lille times tid, det tager at besvare spørgeskemaet." 


\section{Kapitel 1}

\section{Botilbud, velfærdspolitik og socialpædagogiske problemstillinger}

Siden institutionsbegrebets ophævelse i 1998 og indførsel af individuelle botilbud efter 'Lov om social service', har der været interesse for, problematiseringer af og bekymringer om, hvordan lovgrundlaget fortolkes og indsatsen udmøntes over for voksne med udviklingshæmning i botilbud. Hjemmet, med de muligheder for at imødekomme individets ret til selvbestemmelse, privatliv mv. (jf. Menneskerettigheder, Handicapkonvention \& Servicelov ${ }^{7}$ ), er etableret som ideal, og er dermed den 'nye' ramme for det individuelt tilrettelagte pædagogiske arbejde om at imødekomme den hjælp- og st $\varnothing$ ttebeh $\varnothing$ vende, rettighedshavende borgers behov.

Konsekvensen af at adskille bolig og service, så den nødvendige støtte kan ydes uanset boform, er ikke ligetil. I den socialpædagogiske praksis har medarbejderne deres daglige gang og udvirker deres professionalisme (fortolkning af lovgrundlaget) $i$ borgerens eget hjem, med både borgerens rettigheder om privatliv derhjemme, selvbestemmelse og hans ret til at modtage den nødvendige, ofte meget tætte og ikke altid erkendte behov for omsorg som samtidige omdrejningspunkter. Intet er givet på forhånd, som i en mere institutionaliseret ramme, hvor afstukne rammer og strukturer angiver retningslinjerne i en 'kollektiv livsform'.

Det var nye udfordringer, man stod overfor, særligt fordi institutionsbegrebets ophævelse ikke alene var ophævelse af et begreb - altså med henblik på nye måder at tænke tanker om boformer på, men en proces bestående i konkrete skift for beboere og professionelle i det levede hverdagsliv. Skift, der fordrer anderledes fortolkninger i selve dagligdagens handlinger om, hvordan mødet med den rettighedshavende og omsorgsbehøvende beboer jf. lovmaterialet skal/kan gøres af ansatte i mødet med beboeren i beboerens eget hjem. Og nye udfordringer og muligheder for de voksne med udviklingshæmning til et liv i højere grad end hidtil på egne præmisser.

Som følge af institutionsbegrebets ophævelse via Serviceloven er der foretaget forskellige unders $\varnothing$ gelser/evalueringer, og i den sammenhæng er der gennem de seneste ti år udarbejdet flere rapporter om forholdende for de voksne med udviklingshæmning i botilbud. ${ }^{8}$ Den første rapport (PLS Rambø|l 2001) vedrører de spæde erfaringer med $\S$

7 Som COWI/SUS rapporten (2002:88) gør opmærksom på, giver loven ingen anvisning på, hvordan principperne udmøntes i praksis. Dermed bliver fortolkninger/udmøntningerne af lovgivningen interessant at følge.

8 Det er forskelligt, hvordan de voksne med udviklingshæmning i botilbud omtales i de forskellige rapporter. Nogle bruger betegnelsen handicappede, andre udviklingshæmmede. Det er også forskelligt, om der tales om borgeren, beboeren eller brugeren. Derfor er der tale om 'en blandingsform' her i 
111 handleplaner, og herudover blev det dels relevant at spørge ind til det pædagogiske og organisatoriske i en forandringstid/forandringsproces, for at beskrive og analysere indsatsen omkring overgangen fra institutionsbegreb til individuelt botilbud, som er sammenfattet i en tværgående evaluering (Socialministeriet $2003^{9}$ ), dels er de pårørendes oplevelser unders $\emptyset$ gt (Center for Kvalitetsudvikling 2008), dels selve boligforholdene (CLH 2008; Socialpædagogerne 2009), dels, efter 'sagerne' om omsorgssvigt og nedværdigende behandling af voksne med udviklingshæmning rundt omkring i flere af landets botilbud i starten af 2007, en interesse for etiske aspekter ved socialpædagogikken (Socialministeriet 2007; Etikos 2007), og endelig en st $\varnothing$ rre almen interesse/bekymring for de udviklingshæmmedes trivsel i botilbud i Københavns Kommune (Nirás Konsulenterne 2008).

Disse forskelligt rettede rapporter peger på adskillige generelle satsningsområder, dilemmaer og faglige og politisk skiftende og vedvarende problematikker om, hvordan nogle af samfundets svageste borgere imødekommes på deres rettigheder almenmenneskeligt og etisk, såvel som i forhold til de målsætninger om 'afinstitutionalisering', samfundet har på deres vegne. De tendenser, der ad den vej kan fremanalyseres, sammenfattes her i kapitlet som en form for overordnet 'status om bevægelser i hovedproblemstillinger', før analysen i de følgende kapitler af nærværende projekts resultater og indsigter fremstilles. For der sker vedvarende forandringer i udtryk og fortolkninger gennem årene fra Serviceloven var forholdsvis ny ved den første rapport i 2001 til i dag, hvor der er flere års konkrete erfaringer blandt pædagoger, omsorgsmedhjælpere og beboere med at have arbejde og have hjemme i botilbud.

\section{Botilbud som hjem - udformning og indretning}

I Socialministeriets sammenfattende rapport fra 2003 ser man med positivt blik på selve byggeriet/ombygningen af botilbud til voksne med udviklingshæmning, som det har forløbet indtil da. Et byggeri man konstaterer allerede var sat i værk før lovens vedtagelse - det vil sige fra 1980 med udlægningen af Særforsorgen.

Seks år senere - i 2009 - konstateres et efterslæb, som betyder, at skulle den påbegyndte udvikling have været fulgt op, skulle der have været investeret $1.1 \mathrm{mia}$. kr. mere end tilfældet er til nybyggeri og renovering (Socialpædagogerne 2009:3) ${ }^{10}$. Samlet

kapitlet. De fleste af de nævnte rapporter beskæftiger sig i фvrigt med botilbud mv. ud fra lovgivningens afgrænsninger og omfatter derfor også voksne sindslidende m.fl.

9 I denne tværgående evaluering er inddraget rapporten fra COWI/SUS (2002), som dog sammen med PLS Rambøll (2001) også er medtaget særskilt her i kapitlet, idet de hører til blandt periodens væsentligste evalueringer.

10 CLH fremfører, at den planlagte kapacitetsændring i kommunerne er på 71 \%; men at det i praksis (medregnet ombygning og nedlæggelse) betyder en reel kapacitetsudvidelse på 218 boliger. Heraf etableres maximalt 71 efter Serviceloven, resten efter Almenloven (CLH 2008:18). 
set kan man konstatere, at den positive tilgang ved starten af implementeringen af individuelle botilbud, på ingen måde har holdt i årene fremefter. Det konstateres da også senest her i 2009, hvor det for eksempel opgøres, at 35 \% af alle voksne mennesker med handicap bor i en bolig uden eget bad (Socialpædagogerne 2009:6). Med en vis usikkerhed anslår CLH (2008:16), at 18 ud af 69 adspurgte kommuner angiver fysiske faciliteter, som den eller en af de mest almindelige grunde til at en borger afslår et botilbud. Her i afsnittet ser vi på, hvordan botilbuddene, under en vinkel om fysiske rammer, har det.

De pårørende er for størstedelens vedkommende positivt stemte over for botilbuddenes fysiske rammer; men det bemærkes hertil, at analysen af data viser, at jo større boformen er målt på antallet af beboere, jo mindre tilfredse er de pårørende med stedets fysiske rammer (Center for Kvalitetsudvikling 2008:26). Det kan vel tænkes, at store botilbud, altså med mange beboere og dermed mange lejligheder/værelser, giver oplevet indtryk af, at opholde sig i institutionaliserede og institutionaliserende rammer, uanset personalets bestræbelser på at yde den enkelte beboer en individuel indsats.

I COWI/SUS rapporten (2002:51) konstaterer man, at beboernes værelser mange steder er for små. Det betyder ifølge rapporten, at meget liv kommer til at blive levet i de mindre private fælleslokaler. I CLH's analyse fra 2008 af status på botilbudområdet nuanceres problemet om boligernes udformning præcist i den henseende: "Det er vigtigt at tage hensyn til, hvordan boligerne grænser op til fællesarealerne, og hvordan boligerne er adskilt, blandt andet med henblik på at sikre borgerens ret til privatliv" (CLH 2008:34) - Ifølge Socialpædagogernes undersøgelse har $52 \%$ af boligerne egen indgang (Socialpædagogerne 2009:6) - Det vil med 'omvendt fortegn' sige, at 12.700 voksne handicappede, går direkte fra deres bolig ud i et fællesareal (ibid.:9).

Problemet er, at intentionen om at borgeren skal have 'et almindeligt privat livs muligheder' ikke imødekommes på grund af botilbuddenes størrelse og indretning. "Jo mindre grad af selvvalg m.h.t. rum (hvor man opholder sig) og relationer (hvem man er sammen med), jo sværere er det at betragte sin bolig som et egentligt hjem" (COWI/SUS 2002:46). På den måde kan man sige, at problemerne omkring indretning og størrelse både vedrører, hvor meget liv der leves i fællesarealerne, fordi værelserne/lejlighederne er for små til, at beboernes aktiviteter kan foregå der inde, og at opgrænsning til fællesarealer kan betyde uinviteret besøg og forstyrrende støj mv. ${ }^{11}$

I 2009 gøres følgende status i en problematisering af, at botilbuddene er mangelfulde set som 'beboerens eget hjem' - her i forhold til beboerens hjem som arbejdsplads:

11 "Over to tredjedele af medarbejderne og over en tredjedel af de pårørende har oplevet at beboere mistrives som følge af andre beboeres gøren og laden" (Nirás Konsulenterne 2008:155). 
"Mere end $63 \%$ eller mere end 10.700 voksne handicappede lever med, at botilbuddets kontor er placeret i deres fællesboligareal. 54 \% eller mere end 9.100 må leve med, at personalets faciliteter, f.eks. toiletter, er placeret i det fællesboligareal. For $43 \%$ eller mere end 7.200 voksne handicappede ligger personalets mødelokale dør og dør med det fællesboligareal" (Socialpædagogerne 2009:9).

Ligeledes problematiseres det generelt gennem rapporterne, at toilet- og badeforholdene mange steder er utidssvarende derved, at de er for små til at rumme beboernes $n \varnothing d v e n d i g e$ hjælpemidler og det relevante antal hjælpere. Endvidere er toilet og bad ofte delt mellem flere beboere. Det kan for eksempel betyde $k \varnothing$-konflikter og problemer omkring forskellige hygiejnestandarter mellem beboerne, som ikke er værdige forhold for den enkelte. 13 ud af 67 kommuner vurderer at 'ingen' eller kun 'enkelte' af deres botilbud efter Serviceloven har eget bad \& toilet i 2008 (CLH 2008:28).

Også Nirás Konsulenterne problematiserer, at beboernes værelser og badefaciliteter er for små eller utilstrækkelige til at dække beboernes behov (Nirás Konsulenterne 2008:130, 135). Således tillægges specifikt pædagogiske problematikker, der kan følge af for små forhold. "Det gælder især i forhold til beboere, der har behov for at trække sig tilbage til en privatsfære, beboere der har behov for at udfolde sig fysisk, og beboere, der er ved at lære at bo alene" at det pædagogiske arbejdes vilkår forringes, når de fysiske rammer ikke er tilstrækkelige i størrelse, eller på andre måder ikke imødekommer beboerens behov, fremfører Nirás undersøgelsen (Nirás Konsulenterne 2008:127). Næsten hver tredje medarbejder finder ikke de fysiske rammer gode, fordi de oplever dårligt indeklima og nedslidte bygninger (ibid.:116), og fordi de oplever, beboere mistrives på grund af de fysiske rammer (ibid.:126). "Ledere og medarbejdere på flere botilbud giver samstemmende udtryk for, at de oplever, at trange fysiske rammer i flere sammenhænge er uforenelige med beboerens fysiske og/eller psykiske problemstillinger" (ibid.:127). Med reference til SFI-undersøgelsen 'Handicap og samfundsdeltagelse' (SFI 2008) markerer CLH, at "... $9 \%$ af de adspurgte beboere med handicap vurderer at have 'problemer med boligen', det vil sige at komme omkring og benytte boligens faciliteter" (CLH 2008:28) på grund af boligens lille størrelse. Det fremføres, at mistrivsel dels gælder rammerne om den daglige omsorg og pleje (Nirás Konsulenterne 2008:127); men dels også at dårlige fysiske rammer har konsekvenser for, hvorvidt beboerne trives i relation til passende fritidsaktivitetsmuligheder inde og udendørs (ibid.:145).

I 2008 er det en pointe, at utilstrækkelige fysiske rammer fører til nogle af de tilfælde af magtanvendelse, som finder sted over for beboerne. $57 \%$ ledere og $50 \%$ medarbejdere oplever faktisk, at de fysiske rammer 'i nogen grad' eller 'høj grad' øger sandsynligheden for magtanvendelse (Nirás Konsulenterne 2008:61). Det øger de faglige frustrationer for medarbejderne, at de fysiske rammer ikke kan reguleres med pæda- 
gogiske virkemidler. På den måde udføres det pædagogiske arbejde 'på trods' af de fysiske rammer mere end i samspil hermed (ibid.:63-64, 128).

I udmøntningen af Satspuljeaftalen 2004-06 skal utilstrækkelige boliger forbedres (Socialministeriet 2007:10); imidlertid konstateres i 2009, at "Det gale er, at de satspuljemidler, der blev afsat til boligpakken (oktober 2002), ikke er blevet brugt til at ombygge de dårligste enkelt botilbud, som det var sigtet" (Socialpædagogerne 2009:8).

Mens Socialministeriets rapport fra 2007 antager det synspunkt, at 'det gode liv' ikke $n \varnothing d v e n d i g v i s ~ f ø l g e r$ direkte af en god bolig, er 'Socialpædagogernes' pointe (Socialpædagogerne 2009:3), at gode fysiske rammer ganske enkelt giver trivsel. I 2009 har omkring 50 \% (eller 8.400) af alle med handicap i botilbud, ifølge Socialpædagogernes rapport, ikke indflydelse på deres egen dagligdag: Hvornår de vil spise, i bad, gøre rent, se tv etc. (ibid.:8) på grund af utilstrækkelige boligforhold, og undersøgelsen viser, at "Dobbelt så mange voksne handicappede i botilbud over $30 \mathrm{~m}^{2}$ med eget bad, køkken og indgang har fuld indflydelse på boligens indretning og deres egen dagligdag" sammenlignet med handicappede i botilbud på højst $30 \mathrm{~m}^{2}$ uden eget bad og køkkenfaciliteter (ibid.). Således er den seneste konklusion, at boligens størrelse og indretning har direkte konsekvens for borgerens muligheder for at udøve sin lovbestemte ret til selvbestemmelse og privatliv.

\section{Selvbestemmelse}

Det er status i 2003 (Socialministeriet 2003), at de voksne med udviklingshæmning placeres i ledige boliger fortrinsvis efter 'den tomme plads princip', snarere end efter borgerens ret til valg af boform og medbeboere. I 2008 giver visiteringen sig udslag i pædagogiske problemer, ikke alene med hensyn til relevante faglige kvalifikationer hos personalet, fordi beboergruppen i det enkelte botilbud kan være meget forskelligartet, men også blandt beboerne. Konflikter "opstår ... oftest mellem beboere med differentierede diagnoser og adfærdsmønstre. Ledere og medarbejdere oplever det på baggrund heraf som særligt problematisk, at nogle beboere fejlvisiteres" (Nirás Konsulenterne 2008:154). CLH rapporten fremfører at "det særligt [er] inde for visse målgrupper, at der er mangel på botilbud" (CLH 2008:7). En vurdering der kan tyde på, at der efterhånden visiteres mere bevidst end efter 'den tomme plads princip'; men det ændrer ikke på, hvorvidt borgeren har haft indflydelsesmulighed. Hertil kommer også undersøgelsens markering af, at der er meget lille mulighed for at sige nej til et tilbud (det anslås at i 34 \% af tilfældene, vil borgeren kun få ét tilbud inden for det første år (ibid.:15)), hvorfor det første tilbud ofte accepteres (ibid.:14). Samtidig fremføres det dog, at det også sker forholdsvis ofte, at en borger takker nej til et botilbud (ibid.:15).

Deltagelsesmuligheder i hverdagens gøremål vurderes samlet set positivt i de 'familieprægede boligformer', man beskriver botilbuddene som i de første år efter servicelo- 
vens ikrafttræden ${ }^{12}$. Man vurderer dog, at der er meget langt igen, før man rigtigt kan tale om selvbestemmelse, brugerindflydelse og magt over eget liv. Hertil er det omfattende problem, at "hverken beboere ... pårørende eller personale har konkret og indgående kendskab til beboernes rettigheder" (Socialministeriet 2003:19). Det anføres, at der ikke er særlig meget opmærksomhed på brugernes rettigheder (COWI/SUS 2002:59). I Socialministeriets rapport fra 2007 fastslås det, at der er behov for "Mere skarpt fokus på beskyttelse af beboernes grundlæggende rettigheder. Det er derfor centralt at få skærpet opmærksomheden på, at beboere i botilbud har samme rettigheder som alle andre borgere i Danmark" (Socialministeriet 2007:17), og derfor med behov for undervisning af personalet i de grundlæggende rettigheder (ibid.:27-28).

Hertil er det væsentligt at være opmærksom på, at COWI/SUS rapporten (2002:21$22,53)$ gør opmærksom på, at mange ting i dagligdagen foregår på medarbejdernes præmisser og dermed kan siges at være i strid med beboernes selvbestemmelsesret. Således tales der om beboerne i deres nærvær ${ }^{13}$, botilbuddene bærer præg af at være medarbejdernes arbejdsplads ${ }^{14}$, medarbejderne har stor indflydelse på indretningen ${ }^{15}$, medarbejderne står for dagligdagens tidsstrukturering, og de har deres gang i lejligheder/værelser, når beboerne ikke er hjemme. Endvidere kan medarbejderne ikke tilstrækkeligt tegn-til-tale, selvom det er mange beboeres oftest benyttede kommunikationsform

Grad af selvbestemmelse afgøres i høj grad af personalets holdning og fokus på selvbestemmelse (ibid.:51) og af medarbejdernes opmærksomhed over for 'mindsteindgrebsprincippet'. I 2002 oplever man, at det er personalets normer vedrørende sund kost, bordskik, rengøring og hygiejne, der danner grundlag for de regler, der følges i botilbuddene, snarere end beboernes selvvalg gør det (ibid.:54). Og der ses en

$12 \mathrm{Jf}$. rapporterne henviser det familieprægede særligt til mulighed for at deltage i hverdagens praktiske gøremål efter beboernes formåen og interesse (COWI/SUS 2002:52). Mens den 'negative' side af sagen kan siges at vedrøre deling af badeværelse og andre faciliteter med folk, man reelt ikke er i familie med og manglende respekt for beboerens værelse/lejlighed som beboerens private hjem derved, at personalet og andre beboere uinviteret færdes derinde (COWI/SUS 2002:53).

13 "Generelt oplever brugere og pårørende, at brugerne bliver behandlet med respekt og som voksne mennesker. Men der er også brugere og pårørende, der oplever, at der bliver talt ned til brugeren, eller at der bliver talt hen over hovedet på brugerne fra personalets side" (COWI/SUS 2002:56).

14 "For brugere, der har brug for massiv støtte, har en af de negative erfaringer været, at hjemmet netop får karakter af institution. Boligens karakter af privathed og autonomi forsvinder og bliver i stedet arbejdsplads for et skiftende antal hjælpere" (COWI/SUS 2002:102). Problemet om at botilbuddet bærer præg af at være medarbejdernes arbejdsplads mere end beboernes hjem, er fortsat problematiseret i 2007: "Nogle botilbud kan være mere præget af at være arbejdsplads for personalet end beboernes hjem. Det kan bl.a. skyldes, at muligheder i personalets arbejdstidsregler ikke udnyttes i tilstrækkelig omfang, sådan at personalets arbejdstidstilrettelæggelse i unødigt omfang er til hinder for beboernes udfoldelsesmuligheder" (Socialministeriet 2007:16-17).

15 । 2008 er udtrykkes til gengæld fra medarbejdere og pårørende side stor tilfredshed med beboernes mulighed for at indrette deres bolig/værelse, som af konsulenterne vurderes at have et meget individuelt præg (Nirás Konsulenterne 2008:132). 
tendens til, at hverdagen er styret af praktiske og rationelle løsninger (ibid.:55) ${ }^{16}$. I Nirás rapporten behandler man temaet om formelle fora for brugerinddragelse (Nirás Konsulenterne 2008:kap.5) og konkluderer, at man mange steder er nået langt med for eksempel brugerråd og fællesmøder; men at dette også indebærer problemer, fordi beboerne ofte har svært ved at repræsentere hinanden og pædagogisk opleves at 'være et helt andet sted'. Ofte må der i mødet med den enkelte beboer gives valg mellem få alternativer.

Problemerne vedrører tilsyneladende ikke manglende vilje hos medarbejderne, men nærmere manglende tid og metodiske principper, fremføres det i 2002: "Generelt bliver brugerne betragtet som mennesker med ressourcer, der hele tiden kan udvikles, og personalet formulerer da også et ønske om at inddrage brugerne mest muligt i beslutninger der vedrører dem selv. Men personalet nævner ofte, at de mangler tid til at arbejde bevidst og systematisk med metoder og principper for, hvorledes med-og selvbestemmelse kan konkretiseres og udvikles" (COWI/SUS 2002:54). Men også selve visitationsprocessen, som udgangspunkt for det pædagogiske arbejde i det enkelte botilbud, har indflydelse: "... der er behov for at man i visitationen i langt højere grad tager udgangspunkt i borgerens ønsker og behov frem for i den verden, der er og i de tilbud, der nu engang er til stede ... væk fra tænkning i pakkeløsninger" (Etikos 2007:30). Således er der flere niveauer i spil i arbejdet med at sikre borgeren - beboeren i botilbud de individuelt bedste selvbestemmelsesmuligheder.

Generelt problematiseres det sammenfattende, at det konkrete pædagogiske arbejde i botilbud ligger $i$ et spændingsfelt mellem beboerens selvbestemmelsesret og en potentiel risiko for professionel omsorgssvigt, eller mellem individualisering og omsorgssvigt (COWI/SUS 2002:26,98,103,106,107; Nirás Konsulenterne 2008:49). "Udfordringen for den enkelte medarbejder består således $i$ at balancere mellem på den ene side hensynet til den personlige frihed og selvbestemmelsesret, og på den anden side pligten til at yde individuel omsorg" (Nirás Konsulenterne 2008:58). Konklusionen i starten af perioden er, at der ikke mangler vilje til at st $\varnothing$ tte beboerens selvbestemmelse; men at det er en proces med mange nuancer for de professionelle at arbejde med. Der er etablerede magtforhold (COWI/SUS 2002:103), relativt få erfaringer 'på begge sider' (ibid.:104), uafstemte forventninger til hinanden (ibid.), og på beboerens side behov for selvindsigt til at forstå sig som støttebehøvende (ibid.). Det pointeres over midten af perioden, at "For meget selvbestemmelse ville kunne føre til ensomhed og isolation" (Etikos 2007:30); mens man i 2008 behandler problematikken omkring temaet magtanvendelse i forhold til omsorgspligten (Nirás Konsulenterne 2008: kap.6) i naturlig forlængelse af 'sagerne' i 2007 om omsorgssvigt og nedværdigende behandling af

16 Ifølge PLS Rambø|l (2001:114) er der i handlingsplaner en "svag tendens til, at målene bliver enklere og går mere tæt på praktisk mål i dagligdagen, jo sværere nedsat funktionsevne brugeren har" - en relevant pointe, hvis praksis har snæver sammenhæng med handlingsplanerne. 
voksne med udviklingshæmning. "Ifølge medarbejderne er det særligt kravsituationer fx vedrørende beboernes hygiejne eller sengetider, der skaber konflikter" (ibid.:150151).

I 2007 understreges det, at der må arbejdes med en balance i praksis mellem "... beboerens individuelle rettigheder og hensynet til, at beboerne bor i et fællesskab med andre" (Socialministeriet 2007:10). Fællesskabet har ikke været markeret i de tidligere rapporter fra 2002 \& 2003 og kan således siges, at være en udvikling i fortolkningen af lovgrundlaget om beboerens rettigheder $\mathrm{i}$ egen bolig både på politisk og praktisk niveau, hvor der før var mest fokus på 'suveræn ret til et individualiseret tilbud'. Rapporten understreger dog senere, at hjælpen skal være endnu mere individrettet mod beboerens mulighed for et liv på egne præmisser, end det på det tidspunkt ses ${ }^{17}$, og at der findes mange muligheder herfor (ibid.:20). Konkret tales der om at give valgmuligheder og arbejde med kommunikation, der kan fremme beboerens udtryksmuligheder og medborgerkompetencer. Der skelnes mellem kategorierne selvbestemmelse, brugerinddragelse og brugerindflydelse i 2007 (ibid.:20-21).

Når det kommer til brugerindflydelse bredt betragtet i 2008, er det både medarbejderes og lederes opfattelse, at medarbejderne nu kender til beboerens rettigheder til indflydelse. Det vil sige beboerens direkte indflydelses- og selvbestemmelsesret i de lokale botilbud (Nirás Konsulenterne 2008:41) ${ }^{18}$, hvilket må siges at være en udvikling i positiv retning i forhold til tidligere rapporters problematiseringer. $87 \%$ af medarbejderne peger på den daglige kontakt mellem medarbejder og beboer som en måde, beboerne har mulighed for indflydelse, men at det nødvendigvis, med en svær - og måske sværere og sværere målgruppe for det pædagogiske arbejde gør sig gældende, at "... medarbejderne i forhold til brugerindflydelse ofte er nødt til at tolke på beboernes ønsker og behov, fordi beboerne mangler sprog, og at et godt personligt kendskab til beboerne derfor er en forudsætning for, at brugerindflydelse kan finde sted" (Nirás Konsulenterne 2008:45). Således er det ikke uvæsentligt at forstå brugerindflydelse ud fra den enkelte beboers funktionsmåde i et 2008 perspektiv. Beboerindflydelse på fælles og egen sag giver ny anledning til trivsel "... der er sket en stor kulturændring fra

17 I Etikos 2007 hedder det "Det er målet at vi skal bevæge os fra velmenende kollektivisering til anerkendelse af individualiteten" (Etikos 2007:29) således kan der, med en 'sidestilling' af kollektivisering ('vi tænkning') og institutionalisering, siges at være tale om en intention om den modsatte bevægelse end Socialministeriet (2007) med deres markering om fællesskab, som forstås anderledes end en institutionaliserende strategi. Det skal nævnes, at retorikken er skiftende, og at fokus ligger forskelligt i de forskellige rapporter på henholdsvis 'erfaringsbaseret erkendelse af 'det muliges kunst' \& 'det ideelle', forstået som en mere 'idealistisk tilgang'. I 2008 fremhæves følgende erfaring "De [beboerne] har ikke valgt at bo sammen, men de har lært at tilpasse sig svære vilkår" i form af meget blandede - og ikke altid hensigtsmæssige beboersammensætninger (Nirás Konsulenterne 2008:27).

18 "Tendensen er ... at medarbejdernes erklærede viden om beboernes ret til indflydelse stiger, jo længere de har arbejdet med målgruppen" (Nirás Konsulenterne 2008:43). 
tidligere, hvor man stort set ikke tænkte i brugerinddragelse" (ibid.:51) er status i 2008. ${ }^{19}$

\section{Institutionsbegrebets ophævelse i praksis}

Ser man på status, når det drejer sig om institutionsbegrebets ophævelse i den pædagogiske praksishverdag, ser den samlende rapport (Socialministeriet 2003) skeptisk på tingenes tilstand i 2003. Der peges på, at især en påkrævet proces hos aktørerne (ansatte, pårørende og beboere ${ }^{20}$ ) om at ændre holdninger, værdier og vaner, udgør en barriere for den fulde implementering af de socialpolitiske intentioner ${ }^{21}$. I $2003 \emptyset$ nsker beboerne mere tid med deres kontaktperson/medarbejderne, mens det samtidig fremhæves, at hjælpen er blevet mere individuelt tilpasset (og dermed mindre standardiseret), sådan som det netop er lovens intention. COWI/SUS (2002:20) går nærmere ind i boligformerne og fremfører, at jo mindre bo-enhederne er, i videre omfang er institutionsbegrebet ophævet, når det angår hverdagens rutiner, samværs- og samtaleformer. Men status vedrører også at "Det er personalet, der beslutter, hvad brugerne skal have støtte til; vi er bevidste om, hvorfor de bor her - og hvad de har brug for" som en medarbejder citeres (Socialministeriet 2003:18). I 2007 tales der om 'st $\varnothing$ ttet beslutningstagen', så man sikrer, at hjælpen ydes med respekt for den enkeltes selvbestemmelse med afsæt i spørgsmålet "Hvordan ved vi, at det er det, beboeren vil" (Socialministeriet 2007:22), mens man i 2008 problematiserer for små enheder for risiko for blandt andet mindre faglig omsorg end ønskeligt (CLH 2008:23).

Centralt i en holdnings-, værdi- og vaneændring står de sammenhørende rettigheder og pligter, som loven giver om service og ydelser, der kan afhjælpe skævvridning i forhold til reelt at have 'et liv så tæt på det almindelige som muligt'. Det konkluderes tidligt i processen, at der hvor processen både foregår nedefra og op og oppefra og ned, er man i 2003 kommet længst. Det viser sig, at især behov for døgndækning medvirker til problemer med at slippe institutionstankegangen, og at beboernes grad af mobilitet og verbalt sprog ligeledes har indflydelse herpå (COWI/SUS 2002:52).

I 2007 (Socialministeriet 2007:4) bliver det fremhævet, at botilbud ofte stadig omtales som institutioner, fordi det i praksis har været svært at ændre botilbuddenes karakter, og dermed den grundlæggende opfattelse af botilbud som institution. Det er også i

19 "Hovedparten af medarbejderne angiver ... at de 'i nogen grad' eller 'i høj grad' mener, at medarbejdernes forhold til beboerne er kendetegnet ved respekt for individuelle 'ønsker og behov (98\%), anerkendende kommunikations og dialogformer (97\%), omsorg og nærvær (98\%), og anstændighed (97\%)" (Nirás Konsulenterne 2008:149).

20 "Brugeren skal ... opdage og erobre et privatliv - blive bruger i sin egen verden" (COWI/SUS 2002:46). 21 I både de daværende amter og i kommunerne "er der tale om en usikkerhed hos de professionelle overfor, hvorledes man indgår i en ligeværdig dialog med brugere ...[for brugeren kan] oplevelser af afmagt og krænkelser ... ikke altid undgås" (COWI/SUS 2002: 28). 
2007, det spørges, om man overhovedet er moden til at bryde med institutionstankegangen (Etikos 2007:30). Spørgsmålet afvises dog, fordi der nødvendigvis skal gøres op med institutionstankegangen (ibid.) qua institutionsbegrebets ophævelse og beboerens etiske betingende og lovmæssigt forankrede ret til selvbestemmelse og privatliv. Ikke desto mindre en tankegang man altså ikke oplever, der er gjort op med på dette tidspunkt. I praksis viser det manglende opg ør sig ifølge Etikos undersøgelse som 'tvangskollektivisering' af beboerne i det pædagogiske arbejde i botilbuddene (ibid.:31). I 2007 spørges der således til etisk stillingtagen, værdiforankring og kompetenceudvikling, som praktiske fundamenter for de professionelle hjælpere (Socialministeriet 2007), for at komme væk fra en 'institutionskultur' til det ideelle 'gode liv i egen bolig' i botilbuddene. Sådan har det ikke været gennem hele processen og retningen i kvalificering af indsatsen ændrer sig generelt med de forskellige foki, der er i processen. Det er temaet i næste afsnit.

\section{Den faglige selvforståelse, trivsel og opkvalificeringsstrategier}

I Socialministeriets opsamlende evalueringsrapport fra 2003 konstateres det, at forskellige faggrupper qua deres faglige selvforståelse har forskellige tilgange (og dermed forskellige succeskriterier) i forhold til at ophæve institutionsbegrebet i praksis hvad angår definition af beboerens behov og holdninger til grænser mellem selvbestemmelse og omsorgssvigt (Socialministeriet 2003). Der efterspørges både metodeudvikling, efteruddannelse og tværfaglig erfaringsudveksling. Og så peges der på, at det sundhedsfaglige personale mangler socialpædagogisk indsigt ${ }^{22}$.

Det fremhæves i 2001 (PLS Rambøll:141-142) og 2003, at blandt andre pædagogiske medarbejdere oplever, at dokumentation/skriftligt arbejde er vanskeligt. Det er både fordi det ikke er tradition i faget, hedder det, og fordi det tager tid væk fra den egentlige opgave som defineres 'at være sammen med beboerne'. I 2008 problematiseres det fortsat, at oplevelsen er, at medarbejderne bruger "... mere og mere tid på at lave dokumentationsarbejde, som tager tiden fra arbejdet med beboerne" (Nirás konsulenterne 2008:14) ${ }^{23}$. I Socialministeriets rapport fra 2007 bemærkes, at Serviceloven ikke er formidlet med henblik på personalets tilrettelægges af det daglige arbejde, og at en sådan 'praksisrettet omformulering af idealerne' findes påkrævet, så medarbejderne på et mere handlingsrettet grundlag kan tage de faglige udfordringer op, loven foreskriver (Socialministeriet 2007:15). I Etikos rapport (2007) er praktisk forankring gennemgående et ønske/tema, når det drejer sig om implementering af 'det gode liv i egen bolig'. I Nirás Konsulenternes undersøgelse (2008:29) understreges det meget

22 COWI/SUS (2002:24) peger dog også på den modsatte pointe, og i Etikos (2007:26) peges der på at de uuddannede omsorgsmedhjælpere har særligt brug for fagligt løft (ændring af adfærd). Tværfaglige aspekter af den karakter tages ikke op i de efterfølgende rapporter.

23 "Endvidere oplever mange en mistro og mistænkeliggørelse af deres arbejde, blandt andet som følge af stigende krav til dokumentation og skriftlighed" (Nirás Konsulenterne 2008:24). 
kraftigt, at der i deres perspektiv er vidtgående mangler på området i forhold til at beskrive - eller kunne beskrive, hvilke pædagogiske strategier/metoder der arbejdes efter både på ledelses- og medarbejderniveau.

COWI/SUS $(2002: 23,99)$ fastslår, at institutionsbegrebets ophævelse har ført til en st $\varnothing$ rre faglig bevidsthed hos personalet, fordi der i en botilbud-organisering er $\varnothing$ gede krav til fleksibilitet og omstillingsparathed sammenlignet med, hvad der er, når hverdagen er baseret på institutionaliserede rutiner. Men som tidligere nævnt problematiseres det samtidig i 2002, at hverdagen netop stadig er præget af praktiske og rationelle løsninger - et levn fra institutionstiden. I 2007 (Etikos 2007:18) at 'den manglende ophævelse af institutionsbegrebet' har stor betydning. Således kan det tolkes, at man oplever at være nået kortere, men vide/have erfaret mere i 2007 end i 2003?

CLH peger på, at der hersker en opfattelse om, at det kræver et vist beboergrundlag at opretholde både fornuftig økonomi og tilstrækkeligt personalegrundlag (med henblik på udveksling og fagligt niveau uanset sygdom og personaleudskiftning) (CLH 2008:23). Altså, kan man sige, et rationale om at indrette sig ud fra personalenormering og fællesydelser til beboerne som gruppe, frem for til den enkelte beboers ret til et individuelt tilbud? Det kan spørges i den forbindelse, om man så ikke arbejder med kollektivisering og standardisering af ydelser? Samtidig gør rapporten dog også opmærksom på, at der ligger pædagogiske årsager og erfaringer til grund for rationalet: "Det [at få beboere boede sammen] fungerede dårligt ifølge respondenterne fra kommunen, idet de [beboerne] i sidste ende blev mere isolerede og fik mindre faglig omsorg på grund af den personalemæssige begrænsning" (ibid.).

Hvor der tidligere var tale om nødvendig metodeudvikling og efterspørgsel efter efteruddannelse, tales der i 2007 mere konkret om nødvendig nedefra-voksende refleksion over etiske og værdimæssige dilemmaer hos den enkelte og i fagfællesskabet som det, der kan kvalificere og udvikle indsatsen ${ }^{24}$ (Socialministeriet 2007:25) om at "... arbejde på en etisk forsvarlig måde og i overensstemmelse med servicelovens principper om selvbestemmelse" (ibid.:26). Og at "Endelig er det en udfordring i sig selv, at viden om etik og værdigrundlag hos den enkelte leder eller medarbejder ikke altid slår igennem $i$ den pågældendes adfærd og handlinger" (Socialministeriet 2007:17). Således er der bekymring for fagligheden i forståelsen af forholdet mellem teori/ideal og praksis. I Etikos rapport (2007:12) påpeges det, at det ses som væsentligt, at det værdigrundlag der arbejdes med, har udgangspunkt i den enkelte borgers værdier. Man går altså på dette tidspunkt både 'bredt til værks' og ønsker et nationalt generelt, alment og praktisk operationelt formuleret arbejds/værdigrundlag (praksisrettet fortolkning af Ser-

24 Det påpeges, at det er dialog, vidensdeling og formidling af tavs viden, der skal løfte faggruppens kompetencer og skabe ny viden (Socialministeriet 2007:26). Frigivelse af tavs viden er også et aspekt i Etikos (2007:26) diskussion af kompetenceudvikling som noget, der kan ændre praksis positivt. 
viceloven), og helt 'nært til værks' således, at værdierne er lokalt forankret helt tæt på den individuelle borger i botilbud.

I Etikos (2007:18) konkluderer man, at Iøsningen primært ligger i læring i tæt forbundethed med praksis "... en opkvalificering af personalet. Dog ikke i en traditionel opkvalificering i form af efteruddannelse og kurser, men i høj grad også i form af læring i praksis, at uddannelsen af personalet foregår i praksis" (Etikos 2007:19).

Nirás Konsulenterne spørger decideret til behov for efteruddannelse på ganske bestemte områder (Nirás Konsulenterne 2008:118). Derfor er det ikke muligt at identificere, om der stadig er tale om det skifte i medarbejdernes og ledernes holdninger vedrørende henholdsvis 'klassisk' uddannelsesmæssig opkvalificering og praksisnær fagrefleksion, som kunne identificeres i udviklingen i de tidligere rapporter fra 20022007. I 2008 er det nye tiltag fra forvaltningen, normering og tid, der opleves som barriere for at opfylde medarbejdernes identificerede behov for faglig udvikling (ibid.:120, 124).

Et andet aspekt omkring fagligheden angår rekruttering og fastholdelse af fagligt kompetente medarbejdere. Det er generelt i rapporterne, at dette aspekt problematiseres, fordi det er vanskeligt at undgå en endog temmelig kraftig gennemstrømning af faste medarbejdere og stort og skiftende vikarindtag. Gennemstrømningen vurderes at være større, end det er ønskeligt både med henblik på beboernes trivsel og kollegiale og faglige aspekter. "Arbejdsglæden er forsvundet. Rekrutteringen af medarbejdere er vanskelig ... det er meget vigtigt, at arbejdsglæden og den faglige stolthed genoplives" (Etikos 2007:17). Det gøres jf. Etikos rapport ved at opkvalificere medarbejderne til at håndtere dobbeltfunktionen i botilbud mellem 'hjem og arbejdsplads' (ibid.:19). Hos Nirás Konsulenterne peges på, at der skal gøres en stor indsats for at stille det socialpædagogiske arbejde i et bedre lys og med henblik på et bedre image efter den heftige, kritiserende medieomtale i forbindelse med sagerne i 2007 (Nirás Konsulenterne 2008:166-167). Der peges også på, at organisering i teams giver medarbejderne større ejerskab af arbejdet, og at det betyder bedre fastholdelse af gode og velkvalificerede medarbejdere (ibid.:18).

I 2008 påpeges konsekvensen, at der er øget sandsynlighed for magtanvendelse hos nye medarbejdere og vikarer både på grund af dårligere kendskab til den enkelte beboer og til retningslinierne for magtanvendelse (Nirás Konsulenterne 2008:61-62). Det kan således have fatale konsekvenser for beboeren at leve med den kraftige gennemstrømning, der må konstateres at være en realitet inden for området. En beboer citeres: "Hver gang må jeg starte forfra, fordi der kommer nye, og når de ikke kan forstå mig, skal jeg forklare mit liv hver gang. Det har jeg opgivet"(ibid.:149). 
Også de pårørende problematiserer personaleressourcerne (Center for Kvalitetsudvikling 2008:29), idet der angives en tendens til en oplevelse af, at der ikke er tid og ressourcer nok til den enkelte beboer i den nuværende normering. Der er imidlertid forskel på, hvordan arbejdspresset opleves af medarbejderne selv og forstås af ledelsen. Således mener otte ud af ti ledere (79\%), at medarbejderne har en passende arbejdsbelastning, mens fire ud af ti medarbejdere (41\%) føler sig stressede, og $51 \%$ oplever, at de har for travlt til at $\emptyset$ se deres opgaver fagligt forsvarligt (Nirás Konsulenterne 2008:113). Igen peges der på, at en del af dette skyldes høje dokumentationskrav, men også mere plejekrævende opgaver med beboerne og vikarindtag er medvirkende faktorer (ibid.:114).

\section{Handleplanerne}

Handleplanerne skal styrke det individuelle tilbud til borgeren med beskrivelse af formålet med indsatsen (udviklingsperspektivet), så rammen om indsatsen bliver gennemskuelig for de ansvarshavende og forudsigelig og overskuelig for borgeren og forholder sig til borgerens faktiske ønsker, behov og situation. Altså et redskab til bedre at forstå og handle over for borgeren som aktivt subjekt i sit eget liv, frem for som passivt objekt for professionel behandling. Dette problematiseres dog som udgangspunkt: "Faktuelle forhold om hvem der har været med til udarbejdelsen af planen, hvordan målene er koordineret, og hvordan indsatsen skal følges op, fremgår forholdsvis tydeligt ... Men det er straks vanskeligere at aflæse i hvor høj grad målene også tager udgangspunkt i borgerens ønsker og livssituation" (Socialministeriet 2003:32). PLS Rambøll (2001:10) konkluderer, at metodeudvikling til brugerinddragelse i handlingsplanen er i gang, med efterlyser 'mekanismer' til opsamling og spredning af nye metoder. I 2008 er det ledernes opfattelse, at beboerne ikke er beskrevet godt nok, når de flytter ind i botilbuddet (Nirás Konsulenterne 2008:27) og heraf følger pædagogiske problemer "... fejlplacerede beboere kan give anledning til store udfordringer ... at man som medarbejder ikke føler sig fagligt klædt på til at håndtere en bestemt målgruppe, som man opfatter ligger på kanten af den primære målgruppe for botilbuddet ..." (ibid.). Men Nirás Konsulenterne problematiserer også, at der er høj grad af forskel på de enkelte beboeres og botilbuds pædagogiske handleplaner i form af udstrækning, dybde, omfang og formulering (ibid.:32) ${ }^{25}$, eftersom nogle er overordentligt solide, mens andre er særdeles mangelfulde. Således er der ikke alene tale om problemer, der kan skyldes ringe visitationsproces (altså social handlingsplan), men også problemer

25 Det angives som problemløsende på magtanvendelsesproblematikker og dermed på beboerens selvbestemmelsesret, hvis handlingsplanen baserer sig på beskrivelser og observationer af beboerens adfærd, således at fejlfortolkninger af beboerens signaler, i videre omfang end det er tilfældet, undgås (Nirás Konsulenterne 2008:62). 
der kan bunde i manglende eller løse retningslinjer for udarbejdelse af operationelle handleplaner (PLS Rambø|l 2001:38).

Som arbejdsredskab er handleplanen et væsentligt skridt væk fra at møde beboeren med institutionaliserende standardiserede handlingsformer. I 2003 er det dog ikke opfattelsen, at 'den sociale handleplan' sådan rigtigt anvendes i den konkrete daglige indsats (Socialministeriet 2003:32) ${ }^{26} .24 \%$ af kommuner med over 20.000 indbyggere har formuleret individuelle handleplaner i 2001. Det samme har $3 \%$ af kommuner med under 10.000 indbyggere; mens det gør sig gældende for $32 \%$ af de daværende am$\operatorname{ter}^{27}$ (PLS Rambøll 2001:26). Det vurderes, at der er stor usikkerhed om, hvad en § 111handleplan egentligt er for en størrelse. "Evalueringen peger på, at der hersker stor usikkerhed - eller i det mindste meget divergerende fortolkninger - af hvad en $\S 111$ plan er, og hvad den skal anvendes til" (PLS Rambøll 2001:7 se også s.64), og at det præger arbejdet med handleplanerne og implementeringen i praksis. Der arbejdes ikke systematisk med at tilbyde planerne og arbejdet foregår meget lokalt: Det er erfaringen i 2001 og 2003, at det oftest er medarbejdere (kontaktpædagogen) ude i selve botilbuddet, der tager initiativ til udarbejdelse af handleplaner (Socialministeriet 2003:28; PLS Rambø|| 2001:53,55,94,131). Således er der tale om 'pædagogiske handlingsplaner'.

Samtidig er det et problem, at "Undersøgelsen viser, at sagsbehandlerne inviteres med til handleplansmøderne men næsten aldrig deltager" (Socialministeriet 2003:28). En pointe der kan ses i forhold til problematiseringen om faggrupperne og tværfagligheden ovenfor. I 2003 vurderes det, at samarbejdet med andre aktører end sagsbehandlerne (f.eks. pårørende, specialkonsulenter mv.) heller ikke spiller nogen større rolle (ibid.; PLS Rambøl| 2001:117). Man kan på den baggrund udlede, at det er medarbejdere tæt på beboerens daglige liv, der fortrinsvis er initiativtagere og opfølgere omkring beboerens ret til en sammenhængende gennemskuelig indsats jf. hans behov struktureret/fastholdt via en handlingsplan. I 2008 oplever de fleste medarbejdere og ledere dog et generelt godt samarbejde med eksterne samarbejdspartnere omkring beboerne (Nirás Konsulenterne 2008:35). Altså en udvikling i positiv retning.

Det fremhæves, at der er stor forskel på graden af beboerinddragelse i begyndelsen af perioden. Handleplanen er i høj grad decentralt funderet (PLS Rambøll 2001:83),

26 "Der er stadigvæk en klar tendens til, at planerne stadig er de professionelles plan og bærer præg af at være skrevet og udarbejdet af de professionelle med hensyn til såvel målformuleringerne som indholdet af planerne" (PLS Rambøll 2001:40)

27 Det fremføres i CLH rapporten, at omstruktureringen fra amtsligt til kommunalt ansvar giver 'udvekslingsproblemer', hvor borgere bor uden for deres egen kommune eller visiteres til anden kommune, fordi alle pladser i egen kommune er optaget (delvist) af borgere, der egentligt hører til i andre kommuner (CLH 2008:8). "Gennemsnitligt er der 42,6\% af kommunernes botilbudsvisiterede borgere, der bor uden for kommunen, gennemsnitligt 39,7 af kommunens botilbud er beboet af borgere fra andre kommuner" (ibid.). 
som kan give anledning til meget forskelligartede udformninger og strategier, og det understreges, at det er en stor pædagogisk udfordring, at inddrage beboere med meget vidtstrakt udviklingshæmning (ibid.:85,87). I 2001 problematiseres det, at "ingen af respondenterne vurderer, at planen som brugerens drømmeplan eller en kontrakt mellem bruger og system er planens mest vigtige funktion" (PLS Rambøll 2001:101). Denne væsentlige markering finder vi ingen opfølgning på i de senere rapporter. En markering der vedrører om handleplanen mest udtrykker værdier og udviklingsønsker om medarbejdernes eller beboerens levede liv. Men det er væsentligt, at i 2008 vurderer $88 \%$ af medarbejderne beboerindflydelsen på handleplanen som tilfredsstillende (Nirás Konsulenterne 2008:48), og således kan det tænkes, at der er udviklet bedre pædagogiske måder til at inddrage beboerne.

I 2001 vurderer forstanderne, at $20 \%$ af forældrene er med i planudarbejdelsesprocessen (PLS Rambø|l 2001:58). De pårørende svarer i 2008 for 80 \% vedkommende, at de oplever, at personalet arbejder bevidst med beboerens handleplan. Tilfredsheden er imidlertid st $\varnothing r s t$, jo ældre den pårørende er, og jo sjældnere den pårørende besøger beboeren (Center for Kvalitetsudvikling 2008:42). Det bemærkes, at spørgsmål vedrørende handlingsplan har pårørendeundersøgelsens laveste svarprocent på 83. Det kan skyldes, at de pårørende simpelthen ikke har tilstrækkeligt kendskab til beboerens handleplan til at $\varnothing$ nske at besvare spørgsmålet (ibid.).

\section{Et almindeligt liv - kompenserende indsatser}

Mennesker med udviklingshæmning har ifølge Serviceloven ret til kompenserende ydelser (en helhedsorienteret sammenhængende indsats) heriblandt personlig hjælp og pleje, socialpædagogisk støtte, ledsageordning og samværs- og aktivitetstilbud med henblik på et 'liv så tæt på det almindelige som muligt' - individuelt tilpasset og uafhængig af boform.

I 2003 peges der på, at det er et komplekst lovgrundlag, der skal håndteres, og at det betyder, at indsatsen ikke bliver så koordineret og helhedspræget, som det er ønskelig. Men det pointeres også, at lovgivningen lever op til sit formål ved at lægge rammerne for de handicapkompenserende ydelser (Socialministeriet 2003), og at loven medvirker til en ny synliggørelse af brugernes differentierede behov (COWI/SUS 2002:22) ${ }^{28}$. Det er konklusionen i 2002 (ibid.:58), at støtten er mere individuelt tilpasset/mindre standardiseret end tidligere, men at brugeren kun i lille omfang inddrages $i$ beslutninger vedrørende støttens karakter. Brugerne får generelt "den praktiske støt-

28 "Mange ledere - på begge områder - oplever, at de økonomiske rammer er blevet strammere over de seneste år. Ifølge en del af lederne skyldes dette, at der ikke følger tilstrækkelige ressourcer med nye beboere ved indflytning, og at de økonomiske og personalemæssige ressourcer ikke modsvarer beboernes reelle behov." (Nirás Konsulenterne 2008:21). 
te, de har brug for i hverdagen, men flere efterlyser mere tid til at tale med den enkelte bruger ... Brugerne får tilsyneladende ikke tilstrækkelig støtte til at bearbejde følelsesmæssige forhold og får ej heller tid nok til at finde ud af, hvad man gerne vil" (ibid.:58). Altså problematiseres særligt det socialpædagogiske i indsatsen - det daglige samspil, der inddrager, st $\varnothing$ tter og kvalificerer selvbestemmelsen.

I 2008 er status, at beboerne generelt får den individuelle hjælp og støtte, de har brug for. Det er $86 \%$ af medarbejdernes vurdering (Nirás Konsulenterne 2008:141). Som barriere i hverdagen ses særligt personalenormeringen. Men i 2009 er status, at kun lidt mindre end $27 \%$ voksne handicappede "... tildeles den nødvendige støtte og hjælp til kompensation for deres funktionsnedsættelse som en individuel ydelse ... næsten $73 \%$ voksne handicappede i botilbud får støtten og hjælpen som en normering til flere beboere" (Socialpædagogerne 2009:9). Det kan tænkes at det 'kollektive' aspekt, der her fremføres har konsekvenser for, hvor i hvor høj grad den enkelte har indflydelse på sine muligheder for et selvstændigt, privat liv med meningsfulde aktiviteter - og i hvor høj grad boligen i hverdagslivet minder om en institution ${ }^{29}$.

Kompenserende indsatser vedrører i høj grad beboerens mulighed for og støtte til at være del af et socialt meningsfuldt netværk. 'Et almindeligt liv' leves af mange voksne med udviklingshæmning i mindre bo-enheder blandet ind mellem områdets $\emptyset$ vrige bebyggelse, mens andre bor i større samlede mere synlige enheder. Begge dele problematiseres 'frem og tilbage' i de forskellige rapporter. Særligt fremtrædende står generelt set problematiseringen af, at "Udflytningen fra institutioner til egne boliger kan imidlertid risikere $i$ et opbrud af etablerede netværk, en isolation fra omverdenen og en ensomhedsfølelse, der usynliggør handicappede brugere og berøver dem mulighed for i fællesskab at formulere ønsker og krav" (COWI/SUS 2002:38-39). Altså, hvor de voksne med udviklingshæmning $f ø r$ ( $i$ institutionerne) havde hinanden som socialt omdrejningspunkt og dermed 'et almindeligt liv', har de måske nu ingen?

Et andet aspekt vedrørende 'et almindeligt liv' er beboerens mulighed for individuelt meningsfulde aktiviteter i og uden for botilbud. I 2002 vurderes det, at det generelt står dårligere til med udadrettede aktiviteter, jo mere ledsagerkrævende beboeren er. Således konkluderes det i 2002 (COWI/SUS:56), at mange aktiviteter for de svagest fungerende foregår i samme kendte cirkler og grupper. I 2008 er man meget opmærksom på, at beboerens trivsel har med tilbud om passende aktiviteter at gøre (Nirás Konsulenterne 2008:138,141) og fremfører, at botilbuddenes strukturelle rammer kan virke begrænsende herfor (ibid.:143). Trods generel tilfredshed udtrykker $41 \%$ af medarbejderne, at de oplever at beboere 'af og til' eller 'ofte' mistrives som følge af, at de ikke kan tilbydes egnede (motiverende, interessante) aktiviteter (ibid.:145). Tilsvaren-

29 En sådan strategi forsvares som tidligere nævnt i CLH (2008:23) med henvisning til risiko for mindre faglig omsorg på grund af personalemæssige begrænsninger, når botilbuddene er for små. 
de tal gør sig gældende i forhold til passende aktiviteter for beboeren uden for botilbud (ibid.:147). Det kan være dagtilbud, der er tilpassede meget plejekrævende brugere, såvel som meningsfulde aktiviteter for den enkelte på dagtilbuddene, der er problemet.

\section{Pårørende}

De pårørende ses generelt som en væsentlig ressource, der ligger inde med en stor viden om beboerens historie, præferencer, relationer, kommunikation mv. ${ }^{30}$ | 2007 understreges det, at det er "ressourcer, der venter på at blive anvendt" (Socialministeriet 2007:29), hvis ellers rollefordelingen mellem pårørende og professionelle angående ansvar og gensidige forventninger bliver bedre afstemt. "Når det fremgår præcist af afgørelserne [visitationsprocessen], hvilken hjælp beboerne har krav på, kan noget konfliktstof mellem pårørende og personalet undgås, fordi en klar beskrivelse af indsatsen kan være forventningsafstemmende" (Socialministeriet 2007:30). Også i Etikos rapport (2007:12-16) vægtlægges rolledefinitioner og rolleerkendelse mellem beboeren, professionelle og pårørende således, at de pårørende kan være præcist pårørende/netværk for beboeren frem for 'advokater' for, om borgeren får den rette og rettighedsmæssige hjælp og støtte. Det er vigtigt, at " ... personalet ikke ser sig selv som netværkserstattere, men i højere grad som rettighedsopretholdere, således at de pårørende kan koncentrere sig om at være nærværende pårørende. Derfor skal de [ansatte] blive bedre til at opretholde borgerens grundlæggende rettigheder, hvilket fordrer et større kendskab til de grundlæggende rettigheder" (Etikos 2007:13). Således er det, ud over en klar og gennemskuelig rollefordeling, igen bevidsthed om og god udmøntning af rettighederne, der peges på som barriere for at løse den sociale og pædagogiske opgave i botilbud - her når det står i relation til forholdet til de pårørende, som er en del af det socialpædagogiske arbejde i borgerens hjem i botilbud.

I 2008 kommer den landsdækkende pårørendeundersøgelse (Center for Kvalitetsudvikling 2008), hvor 1000 pårørende til beboere i 59 regionale boformer har givet deres tilfredshedsgrad til kende. 75\% svarer, at opholdet i boformerne for handicappede er 'enestående' eller 'godt'. Det begrundes særligt i, at de pårørende føler sig velkomne i botilbuddene (ibid.:33) og at de oplever, at der er en god atmosfære og tryghed for beboeren, som mødes med respekt og omsorg (ibid.:4, 18,19,28.34). Tilfredsheden er generelt størst, jo ældre beboeren og den pårørende er, og jo længere beboeren har boet på boformen (ibid.). Og der ses en "... moderat tendens til, at jo længere en medarbejder har arbejdet inden for feltet, jo større sandsynlighed er der for, at vedkommende har kendskab til de kommunale retningslinier [om pårørendeinddragelse]" (Nirás Konsulenterne 2008:97).

30 I pårørende undersøgelsen fra 2008 svarer 80 \% af de pårørende at personalet interesserer sig for deres erfaring og viden om beboeren (Center for Kvalitetsudvikling 2008:37). 
På den mindre tilfredse side ses svar, der vedrører personaleressourcerne: Der er stor personaleudskiftning og mange vikarer, som de pårørende ikke bliver gjort bekendte med, gør de opmærksom på. Det har konsekvenser for, hvor udadrettet personalet kan tillade sig at være i forhold til aktiviteter med beboerne, oplever de pårørende (Center for kvalitetsudvikling 2008: 4, 25, 29, 39) ${ }^{31}$. Aktiviteter er et af de pårørendes særlige kritikpunkter, og det markeres også med tyngde, at stor udskiftning i personalet $\emptyset$ ger utryghedsoplevelser for både beboer og pårørende (ibid.:39).

Pædagogisk fremføres det, at "Dårlige resultater er ikke nødvendigvis tegn på problemer med pleje eller pasning. Boformen kan have en anden pædagogik, end de pårørende ønsker, eller der kan være juridiske forhold, der ikke stemmer overens med de pårørendes forventninger" (Center for Kvalitetsudvikling 2008:17). Således kan en overenskomst, på baggrund af den ovenfor omtalte forventningsafstemning, have trange kår, hvis målet er mere samarbejde og mere tilfredse pårørende ${ }^{32}$. Rapporten konkluderer, at der er plads til forbedring, hvad angår inddragelse af pårørende, eftersom 30-40 \% af de pårørende angiver, at de kun 'i nogen grad' inddrages tilstrækkeligt i beboerens liv (ibid.:35). Mens Nirás Konsulenternes (2008:97) rapport fremhæver, at der er stigende fokus på inddragelse af de pårørende, fremgår det også, at hver tiende pårørende 'slet ikke' eller 'i ringe grad' oplever et godt forhold med personalet (ibid.:99).

Et væsentligt dilemma er her i spil set ud fra 'et pædagogisk perspektiv på de pårørende'. En pædagogisk udfordring i arbejdet med voksne med udviklingshæmning i botilbud vedrører nemlig, at "Særligt opleves det som en stor udfordring at balancere mellem respekten for beboerens selvbestemmelse og medarbejdernes tavshedspligt $i$ den forbindelse - og de pårørendes ønske om indflydelse og medbestemmelse" (Nirás Konsulenterne 2008:98). Det er således ikke altid i beboerens egen interesse, at pårørende har stor indflydelse på, hvorledes hans liv leves. Det kan være et aspekt medarbejderne har for øje omkring beboerens ret til privatliv og selvbestemmelse, som giver de pårørende en dårligere oplevelse af samarbejdet, end der 'reelt' er tale om (ibid.:157). Der er en tendens til, at de pårørende, der ofte besøger botilbuddet - og dermed har det bedste kendskab hertil - er mindre tilfredse end gennemsnittet" (Nirás Konsulenterne 2008:106).

I den landsdækkende pårørendeundersøgelse er det en del af hovedresultatet at "jo ældre beboere og pårørende er, jo mere tilfredse er de med boformen ... personer, der personligt har kontakt med og kendskab til de regionale boformer for handicappede,

31 Det er i det store hele de samme indvendinger, der gør sig gældende i Nirás Konsulenternes undersøgelse (2008:100). Herudover peges der på mangelfuld mulighed for at have indflydelse på valg af kontaktperson og dagligdagsindflydelse (ibid.:103).

32 I rapporten opfordres det enkelte botilbud til at tage hånd om overensstemmelser mellem pårørendes forventninger og botilbuddets ydelser (Center for Kvalitetsudvikling 2008:17). 
er godt tilfredse med den service der ydes af regionerne " (Center for kvalitetsudvikling 2008:6). Men i de særskilte spørgsmål er tendensen gentagne gange: "jo mindre de pårørende besøger beboeren, jo mere tilfredse er de med boformens hjælp til at udvikle evner og kompetencer" (ibid.:21) og "jo ældre beboeren er, og hvis den pårørende besøger beboeren mindre end en gang om måneden, jo mere tilfredse er de pårørende med mængden af aktiviteter" (ibid.:25); "Jo ældre beboeren er, og hvis de bes $\varnothing$ ger beboeren mindre end en gang om måneden, er de mere tilfredse med antallet af personaler" (ibid.:29); igen ift. handleplan (ibid.:42).

\section{Ledelse}

I 2002 (COWI/SUS 2002:88) er temaet ledelse behandlet som et emne om, hvorvidt kommuner og amter lever op til Servicelovens bestemmelser, og man konkluderer, at Serviceloven er et skub til den igangværende udvikling af institutionsbegrebets ophævelse. I COWI/SUS rapporten fra 2002 og Socialministeriets rapport fra 2003 lægges der vægt på det kommunale og amtskommunale samarbejde. På den måde ligger fokus på visitation og social handlingsplan.

På samarbejdsniveau mellem forvaltning og botilbud hedder det i 2008, at "Selvom de fleste ledere og medarbejdere oplever, at botilbuddet har et fornuftigt samarbejde med forvaltningen, så fremhæves der mange steder også en 'vi-dem"' (Nirás Konsulenterne 2008:34). Det påpeges, at tilbagemelding på magtanvendelsesindberetninger er et af de områder, hvor samarbejdet med forvaltningen ikke er optimalt. Der opleves gråzonetilfælde i forhold til retningslinierne for magtanvendelse og langsom tilbagemelding på indberetninger (ibid.:71). Også i forhold til handlingsplanerne inddrages ledelsesniveauet."Det er alfa og omega, at ledelsen i kommunerne og amtskommunerne begynder at prioritere arbejdet med §111-planer, såfremt disse skal udarbejdes - og på et tilfredsstillende kvalitativt niveau. Der kan skubbes på fra medarbejdernes side, men ledelsen skal være parat til at afse de nødvendige tidsmæssige og økonomiske ressourcer og prioritere arbejdet med §111-planer" (PLS Rambøll 2001:145).

Først i Socialministeriets rapport fra 2007 (Socialministeriet 2007:23-25) behandles emnet 'den pædagogiske ledelse'. Det vægtlægges, at lederen er det pædagogiske personales ledelse, som samtidigt skal håndtere roller i forhold til politikere og forvaltning, og til medarbejderne og medarbejdernes forhold med beboerne. Der peges (formentligt efter 'sagerne' i vinteren 2007) på ledernes behov for kompetenceudvikling til at sætte etik og værdier på dagsorden (ibid.:25). I Etikos (2007:19-24) står det centralt, at ledelse er et relationelt anliggende: Lederen har sammen med de andre aktører på botilbudsområdet det endelige ansvar for en ordentlig værdiforankring, så det ikke er 'tilfældige værdier efter forgodtbefindende', der er det praktiske arbejdes grundlag. Man kan således sige, at der peges på ledelsens ansvar for en ordentlig implemente- 
ringsmulighed i den pædagogiske praksis af forvaltningens politikker. Hver tiende medarbejder kunne tænke sig en bedre opfølgning fra deres nærmeste ledelse (Nirás Konsulenterne 2008:72) i forbindelse med indberetninger. På den måde problematiseres forholdet mellem ledelse og medarbejdere altså også.

I Nirás Konsulenternes rapport (2008:12-25) er ledelse behandlet både i forhold til forvaltnings- og botilbudsniveau. På forvaltningsniveau er status, at en tredjedel af de adspurgte kritiserer forvaltningens strukturering for at være præget af mange udskiftninger på chefniveau, og at udviklingstiltag ikke følges til dørs i Københavns Kommune. Således er det fortsat problematiseret, at der ikke er sammenhæng mellem de udviklingsaktiviteter, der tages initiativ til ovenfra og implementeringsmuligheder i den pædagogiske praksis i botilbuddene, præcist ligesom i de tidligere rapporter fra botilbuddenes første år efterspurgte. "Det handler om, at man på bostederne ofte oplever, at tiltag fra forvaltningen ikke hænger sammen med den hverdag, man har på bostederne" (Nirás Konsulenterne 2008:13) og 'arbejdsro' efterspørges (ibid.:14). På botilbudsniveau er medarbejdere og ledelse i 2008 enige om, at der er klare retningslinier og procedurer for arbejdet, men begge parter stiller sig også positive overfor og peger på nødvendigheden af udvikling (ibid.:16-17).

\section{Afslutning}

Samlet er indtrykket fra gennemgangen af rapporterne fra 2001 til 2009, at det sociale og socialpædagogiske område om voksne med udviklingshæmning i botilbud både er kendetegnet ved udviklingsmulighed og udviklingsbehov. Det gælder altså, at der peges på muligheder for at forbedre indsatsen helt fra forvaltningsniveau - hvor udviklingsbehovet vedrører, at udbuddet og tilstanden/standarden af de konkrete botilbud lader meget tilbage at $\emptyset$ nske, og der ifølge rapporterne savnes sammenhæng mellem tiltag og tempi i det konkrete pædagogiske arbejde, over det sociale/sagsbehandlingsniveauet om visitation - hvor der ifølge rapporterne kunne visiteres med større følsomhed over for den enkelte borger og botilbuddenes beboersammensætning. Og endelig til det pædagogiske niveau hvor højt refleksionsbehov over beboerens ret til selvbestemmelse, privatliv, omsorg og støtte er nøglepunkter.

Rapporterne giver indtryk af, at udviklingsbehovet hænger nøje sammen med de nye opgaver, der følger af at skulle tilbyde reelle individuelle tilbud om socialpædagogisk støtte uanset boform til den enkelte borger. Heraf følger sociale og pædagogiske udfordringer ikke bare om andre, ikke institutionelle, måder at tænke på, men særligt nye måder at handle på i selve mødet med den enkelte voksne med udviklingshæmning og i udformningen af indsatsen sammen med borgeren/beboeren.

Således er det tydeligt, at de sociale og pædagogiske udfordringer ikke er stoppet med omlægningen fra institution til botilbud, idet der er dukket (nye) dilemmaer og udfordringer op, som ikke alene kan Iøses af 'teoretisk vej', men skal udvikles, perspek- 
tiveres og løses i den konkrete kommune/region, i det konkrete botilbud, præcist i møderne og erfaringer med $m \varnothing$ derne med de konkrete borgere/beboere og via konkret fokus på og understøttelse af området helt overordnet. 


\section{Kapitel 2}

\section{Medarbejderprofiler og medarbejdernes over- ordnede syn på arbejdet}

Efter forrige kapitels gennemgang af centrale undersøgelser efter Servicelovens ikrafttræden inden for området bo- og dagtilbud til voksne med psykisk/fysisk handicap, samler interessen i de følgende kapitler sig om de 245 pædagoger og omsorgsmedhjælpere, som indgår i den spørgeskemaundersøgelse, der i efteråret 2008 gennemf $\varnothing$ tes blandt botilbud i Københavns Kommune. ${ }^{33}$ I fokus er deres oplevelse af dagligdagen, synspunkter på arbejdsområdet og holdninger til, hvor professionsudvikling inden for området især bør vægtes.

\section{Medarbejderprofiler - et indledende indblik}

Spørgeskemaunders $\varnothing$ gelsens deltagere fordeler sig med 176 pædagoger og 66 omsorgsmedhjælpere, hvilket betyder, at under en tredjedel (27 \%) ikke har en pædagogisk uddannelse. Ikke overraskende er der en overvægt af kvindelige medarbejdere, men andelen af mandlige medarbejdere er dog sammenlignet med andre omsorgsområder ganske høj, nemlig samlet $28 \%$ og altså lidt mere end hver fjerde, og blandt omsorgsmedhjælperne er næsten fire ud af ti mænd (39\%), som det fremgår af tabel $4:^{34}$

Tabel 4. Køn

\begin{tabular}{|l|c|c|}
\hline Køn & $\begin{array}{c}\text { Kvinder } \\
\text { i \% }\end{array}$ & $\begin{array}{c}\text { Mænd } \\
\text { i \% }\end{array}$ \\
\hline Alle & 72 & 28 \\
\hline Pædagoger & 76 & 24 \\
\hline Omsorgsmedhjælpere & 61 & 39 \\
\hline
\end{tabular}

\footnotetext{
${ }^{33}$ I undersøgelsen er ikke medtaget 'rene' dagtilbud, men et par af de deltagende botilbud har integreret dagtilbud, og medarbejderne her deltager. Det er dog et fåtal, det drejer sig om, som det fremgår senere i kapitlet. I alt er det $2 \%$, der udelukkende arbejder i dagtilbuddet, mens $5 \%$ har arbejdsopgaver såvel i døgn- som dagdelen, og resten - $93 \%$ - arbejder udelukkende i døgndelen. I rapporten anvendes derfor generelt udtrykket botilbud, mens dagtilbud omtales under svarmønstre, der direkte inddrager denne del af tilbuddenes samlede indsats. Se i $\varnothing$ vrigt Bilag 1 for beskrivelse af unders $\varnothing$ gelsens datagrundlag mv.

${ }^{34}$ Nummerering af tabeller følger spørgeskemaets oprindelige nummerering og er således ikke i kronologisk orden. Grunden hertil er, at det så er muligt at gå mere i dybden med data (inklusive de mange data, der ikke er direkte medtaget i teksten) ved at se de korresponderende tabeller i bilag 3. I forbindelse med tabellerne skal også nævnes, at de er bygget op, så de samlede procenttal - enten vandret eller lodret - i alt er 100, men da der er afrundet til hele tal, er det ikke usædvanligt, at summen lander på 99 eller 101. Der er altså ikke tale om en fejl i de tilfælde, summen ikke er præcis $100 .$.
} 
Mens der inden for eksempelvis daginstitutionsområdet er en høj repræsentation af helt unge mænd og stort set kun kvinder i aldersgruppen over 40 år, ${ }^{35}$ ser fordelingen mere jævn ud inden for botilbudsområdet. Her fordeler de mandligemedarbejdere sig aldersmæssig med lidt over halvdelen under de 40 år (57\%) og mere end fire ud af ti mænd (43\%) er således over 40 år.

I en anden sammenhæng er der dog en markant aldersforskel at spore, idet der er en klar overvægt af 'ældre' pædagoger og 'yngre' omsorgsmedhjælpere. Det fremgår af følgende tabel:

Tabel 5. Alder

\begin{tabular}{|l|c|c|c|c|c|c|c|c|c|}
\hline Alder & $\begin{array}{c}\mathbf{2 0 -} \\
\mathbf{2 5} \\
\mathbf{i} \%\end{array}$ & $\begin{array}{r}\mathbf{2 6 -} \\
\mathbf{3 0} \\
\mathbf{i} \%\end{array}$ & $\begin{array}{c}\mathbf{3 1 -} \\
\mathbf{3} \\
\mathbf{i} \%\end{array}$ & $\begin{array}{r}\mathbf{3 6} \\
\mathbf{4 0} \\
\mathbf{i} \%\end{array}$ & $\begin{array}{c}\mathbf{4 1 -} \\
\mathbf{4 5} \\
\mathbf{i} \%\end{array}$ & $\begin{array}{c}\mathbf{4 6 -} \\
\mathbf{5 0} \\
\mathbf{i} \%\end{array}$ & $\begin{array}{c}\mathbf{5 1 -} \\
\mathbf{5 5} \\
\mathbf{i} \%\end{array}$ & $\begin{array}{c}\mathbf{5 6 -} \\
\mathbf{6 0} \\
\mathbf{i} \%\end{array}$ & $\begin{array}{c}\mathbf{6 1 -} \\
\mathbf{6 5} \\
\mathbf{i} \%\end{array}$ \\
\hline Alle & 10 & 17 & 10 & 10 & 14 & 13 & 9 & 13 & 4 \\
\hline Pædagoger & 5 & 16 & 8 & 9 & 14 & 12 & 12 & 18 & 6 \\
\hline $\begin{array}{l}\text { Omsorgs- } \\
\text { medhjælpere }\end{array}$ & 23 & 17 & 15 & 11 & 14 & 16 & 2 & 2 & 0 \\
\hline
\end{tabular}

Mens 21 \% af pædagogerne er i aldersgruppen 20-30 år, er der dobbelt så mange (40 \%) i denne aldersgruppe blandt omsorgsmedhjælperne. Blandt medarbejdere over 50 år er situationen omvendt og endnu mere udtalt. Mens $36 \%$ af pædagogerne er over 50 år, er det kun $4 \%$ af omsorgsmedhjælperne, der tilhører denne aldersgruppe.

Beskrevet på en anden måde er meget få pædagoger under 25 år (5\%) og 25 \% over 55 år, mens det modsatte gør sig gældende blandt omsorgsmedhjælpere, hvor næste en fjerdedel (23\%) er under 25 år og blot $2 \%$ over 55 år.

Den gennemsnitligt relativt høje alder, hvor samlet over halvdelen (53\%) er over 40 år indikerer, at der er tale om en erfaren medarbejdergruppe. Det holder dog ikke umiddelbart stik, hvis der ses på længden af ansættelse på den nuværende arbejdsplads. Kun halvdelen af alle medarbejdere (52\%) angiver at have været ansat på botilbuddet $\mathrm{i}$ mere end 3 år, og en fjerdedel ( $23 \%$ ) har været ansat i mindre en 1 år, jf. følgende tabel:

\footnotetext{
${ }^{35}$ Bryderup, Langager og Robenhagen 2000.
} 
Tabel 11. Længde af din nuværende ansættelse

\begin{tabular}{|l|c|c|c|}
\hline $\begin{array}{l}\text { Længde af nuværende ansæt- } \\
\text { telse? }\end{array}$ & $\begin{array}{c}\text { Pædagoger } \\
\text { i \% }\end{array}$ & $\begin{array}{c}\text { Omsorgs- } \\
\text { medhjælpe- } \\
\text { re } \\
\text { i \% }\end{array}$ & $\begin{array}{c}\text { Alle } \\
\text { i \% }\end{array}$ \\
\hline Under 6 måneder & 10 & 8 & 10 \\
\hline Fra 6 måneder til under 1 år & 12 & 15 & 13 \\
\hline Fra 1 år til under 2 år & 14 & 27 & 17 \\
\hline Fra 2 år til under 3 år & 6 & 12 & 8 \\
\hline Fra 3 år til under 5 år & 11 & 17 & 12 \\
\hline Fra 5 år til under 10 år & 24 & 14 & 21 \\
\hline Fra 10 år til under år 20 år & 23 & 7 & 19 \\
\hline Fra 20 år og opefter & 0 & 0 & 0 \\
\hline
\end{tabular}

Selvom hver fjerde pædagog (24\%), som det fremgår af tabel 5, er over 55 år, har ingen haft '20 års jubilæum' på arbejdspladsen og kun knap halvdelen (47 \%) har mere end 5 års anciennitet på bo- eller dagtilbuddet.

Ses på anciennitetsforskelle mellem omsorgsmedhjælpere og pædagoger er mønstret, at der ikke er den stor forskel i procentdelen, der har mindre end 1 års ansættelse, mens der er betydeligt færre omsorgsmedhjælpere end pædagoger, der har mere end 5 års ansættelse på stedet bag sig, henholdsvis en femtedel (21\%) af omsorgsmedhjælperne og som nævnt ovenfor næste halvdelen (47\%) af pædagogerne.

Til gengæld viser en særkørsel, at der samlet set ikke er markante forskelle mellem køn og anciennitet. $39 \%$ af de kvindelige medarbejdere mod $43 \%$ af de mandlige har under 2 års ansættelse på stedet bag sig, men i den anden ende $42 \%$ kvinder og $35 \%$ mænd har været ansat her mere end 5 år.

Til det samlede billede af arbejdserfaringer inden for botilbud hører dog, at der kan være tale om stor 'rotation', således at medarbejderne nok er relativt nye på det aktuelle botilbud, men samlet set har arbejdet inden for området i mange år. Eventuelt forstærket af omstruktureringer som følge af Servicelovens indførelse i 1998 og strukturreformen i 2007.

Her peger svarmønstre fra et andet spørgsmål (tabel 33, se Bilag 3) på, at det er tilfældet for en del især pædagogers vedkommende. Her oplyser knap hver femte (18 $\%$ ), at de har mere end 20 års erfaring inden for området bag sig (mod $7 \%$ af omsorgsmedhjælperne), $40 \%$ af alle pædagoger (mod $11 \%$ af omsorgsmedhjælperne) har mere end 10 års samlet anciennitet. I den anden ende af anciennitetsspektret er det præcist halvdelen af omsorgsmedhjælperne, der har mindre end 4 års samlede arbejdserfaringer inden for området bag sig, mod en fjerdedel af pædagogerne. 
Selvom der ikke er nogen entydig sammenhæng mellem alder og anciennitet inden for arbejdsområdet efterlader ovennævnte tabeller indtrykket af et professionsområde, hvor der er relativt mange pædagoger, der trods en høj alder ikke har så mange års arbejde inden for botilbud bag sig, og at en del således påbegynder arbejde inden for området i en sen alder, mens der er en del 'yngre' omsorgsmedhjælpere, der stopper efter få års arbejde. ${ }^{36}$

Med hensyn til civilstand tegner der sig - den relativt høje gennemsnitsalder taget i betragtning - et overraskende billede. Kun lidt over halvdelen (52 \%) oplyser at de er 'Gift eller samboende', og der er dermed næsten lige så stor en del af medarbejderne, der enten beskriver sig selv som 'Enlig (evt. bofællesskab)' (35 \%) eller 'Bor alene, men har fast kæreste' (13\%), og der er en større andel omsorgsmedhjælpere end pædagoger, der markerer 'singlestatus' (55\% omsorgsmedhjælpere mod $48 \%$ pædagoger), men ikke større end der statistisk set for begge faggrupper er en meget høj procentdel, der bor 'single' sammenlignet med 'det normale' i Danmark som helhed. ${ }^{37}$

Det overraskende høje antal medarbejdere, der har angivet at de bor alene, kunne selvom aldersfordelingen ikke peger i denne retning - tolkes som mange i faste tilkaldevikariater med relativt kortvarige ugentlige timetal, medarbejdere der eventuelt studerer sideløbende med arbejdet i botilbud, men det er ikke tilfældet.

Det personale med pædagogiske funktioner i dagligdagen, der deltager i unders $\varnothing$ gelsen er henholdsvis fastansatte, fast tilkaldevikar og længerevarende vikariater, og fordelingen er som følger:

Tabel 1B. Ansættelsesform

\begin{tabular}{|l|c|c|c|}
\hline Ansættelsesform & Alle & $\begin{array}{c}\text { Antal pædago- } \\
\text { ger } \\
\text { i } \%\end{array}$ & $\begin{array}{c}\text { Antal omsorgs- } \\
\text { medhjælpere } \\
\text { i } \%\end{array}$ \\
\hline Fastansat & 89 & 96 & 69 \\
\hline Vikar: Fast tilkaldevikar & 6 & 0 & 23 \\
\hline $\begin{array}{l}\text { Vikar: Længerevarende } \\
\text { vikariat }\end{array}$ & 5 & 4 & 8 \\
\hline
\end{tabular}

\footnotetext{
${ }^{36}$ Sammenholdes dette indtryk med parallelunders $\emptyset$ gelsen omkring omsorgsmedhjælpere på landsplan (Robenhagen, Langager, Højmark og Allerup 2009) viser der sig markante forskelle. I denne spørgeskemaunders $\varnothing$ gelse (hvor de FOA/LFS-organiserede omsorgsmedhjælpere fra Københavnerunders $\varnothing$ gelsen er inkluderet) er svarmønstrene på spørgsmål om alder og anciennitet blandt omsorgsmedhjælpere inden for bo- og dagtilbudsområdet, at næsten halvdelen (47 \%) er over 50 år (mod 4 \% i København), at $50 \%$ har mere end 5 års anciennitet på samme arbejdsplads (mod 21 \% i København) og endeligt at 43 \% har mere end 10 års samlede arbejdserfaringer inden for området mod 13 \% i København.

${ }^{37}$ I aldersgruppen 20 til 59 år bor samlet set $19 \%$ af alle mænd og $14 \%$ af alle kvinder alene (2009 tal). Nyt fra Danmarks Statistik 2009.
} 
Næsten alle (96\%) af pædagogerne er fastansatte, mens det gælder for lidt mere end to ud af tre omsorgsmedhjælpere (69\%), men der er en fjerdedel ( $23 \%)$ af omsorgsmedhjælperne, der er faste tilkaldevikarer, og det er især blandt denne gruppe, at studerende med sideløbende job skal findes.

Med hensyn til ugentlig arbejdstid er det et fåtal (hvor mere løse tilkaldevikarer som nævnt ikke er med), der er på et lavt ugentligt timetal:

Tabel 12. Ugentlig arbejdstid

\begin{tabular}{|l|c|c|c|}
\hline Ugentlig arbejdstid & Pædagoger & $\begin{array}{c}\text { Omsorgs- } \\
\text { medhjælpe- } \\
\text { re } \\
\mathrm{i} \%\end{array}$ & Alle \\
\hline Op til 19 timer & 1 & 15 & 4 \\
\hline Mellem 20 og 27 timer & 3 & 5 & 4 \\
\hline Mellem 28 og 31 timer & 5 & 7 & 6 \\
\hline Mellem 32 og 36 timer & 11 & 20 & 13 \\
\hline 37 timer eller mere (fuld tid) & 80 & 54 & 73 \\
\hline
\end{tabular}

Tre ud af fire medarbejdere (73\%) er fuldtidsansat, og kun $4 \%$ ansat i mindre end 20 timer ugentligt (og af dem stort set alle omsorgsmedhjælpere).

Det samlede billede er således, at der er tale om en medarbejdergruppe, for hvem jobbet er den primære beskæftigelse, og selvom 'kun' 80 \% er fuldtidsbeskæftigede, er det et fåtal ( $8 \%)$, der ikke er tilfredse med den aktuelle ansættelsesgrad. Blandt de ikke tilfredse er det fifty-fifty blandt omsorgsmedhjælperne om de ønsker flere eller færre ugentlige arbejdstimer, mens de pædagoger, der har sat kryds ved 'nej til tilfredshed med nuværende timetal' alle markerer, at de ville foretrække et lavere ugentligt timeantal. ${ }^{38}$

Yderligere to karakteristika omkring de deltagende omsorgsmedhjælpere og pædagoger skal afslutningsvist i denne korte personprofil nævnes.

Først at den 'etniske sammensætning' er en smule lavere end befolkningssammensætningen i Københavnsområdet, idet samlet 13 \% svarer 'ja' til at de 'har anden etnisk baggrund end dansk', mens $85 \%$ svarer 'nej' og $2 \%$ 'ønsker ikke at svare'. ${ }^{39}$ Bag de 13 \% 'ja-svar' gemmer sig en fordeling, hvor hver tiende pædagog svarer 'ja', mens det er lidt over hver femte (22\%) af omsorgsmedhjælpergruppen.

Dernæst spørgsmålet: 'Er du medlem af en fagforening?' Samlet svarer 87 \% 'ja', mens $11 \%$ svarer 'nej' og $2 \%$ 'Ønsker ikke at svare'. Bag denne samlede svarfordeling er en relativ stor forskel mellem de to faggrupper, idet kun $4 \%$ af pædagogerne svarer, at de ikke er fagligt organiserede, mens det samme gælder en tredjedel (32\%) af om-

\footnotetext{
${ }^{38}$ Se Bilag 3, tabel 13 og $13 \mathrm{~A}$.

${ }^{39}$ । 2005 havde $19 \%$ af kommunens befolkning anden etnisk baggrund end dansk, men ses på arbejdsstyrken havde 10,8\% anden etnisk baggrund (Københavns Kommune 2005).
} 
sorgsmedhjælperne. En særkørsel af datamaterialet med sammenholdning af 'Længde af nuværende ansættelse' og nej-svarerne viser ikke uventet, at en stor del af de ikkeorganiserede skal findes blandt de nyansatte. $40 \%$ har været ansat (nuværende ansættelse) i under 1 år, $20 \%$ mellem 1 og 2 år, men der er trods alt $16 \%$ af de ikke organiserede, der har været ansat på samme arbejdsplads i mere end 5 år.

\section{Arbejdspladserne og medarbejdernes karakteristik af beboer- ne/ brugerne}

Hvilke beboer-/brugergrupper arbejder omsorgsmedhjælperne og pædagogerne så sammen med, og under hvilke botilbudsformer? I unders $\varnothing$ gelsen deltager medarbejdere fra 22 forskellige botilbud i Københavns Kommune. Det drejer sig om botilbud oprettet efter $\S 108$ og $\S 107$ i 'Lov om social service', mens to steder har tilknyttet dagtilbud (\$103).

I rapporten er de delt op i tre grupperinger: ${ }^{40}$

- Botilbud med integreret dagtilbud

- Botilbud

- Bofællesskaber, opgangsfællesskaber og solistboliger

Langt den overvejende del af deltagerne i unders $\varnothing$ gelsen arbejder udelukkende i d $\varnothing$ gntilbud (93\%), og kun $2 \%$ arbejder alene i dagtilbud, mens $6 \%$ har arbejdsopgaver i begge afdelinger af deres arbejdssted. Fælles er, at ni ud af ti har daglige arbejdsopgaver $\mathrm{i}$ forhold til voksne med udviklingshæmning, og for en dels vedkommende samtidig med voksne med andre funktionsvanskeligheder.

En oversigt over de grupperinger af voksne (hvor en del af beboerne har sammensatte vanskeligheder, eksempelvis udviklingshæmning med 'psykiatrisk overbygning' eller såvel psykiske som fysiske funktionsnedsættelser), der er medarbejdernes kontaktflade, er: ${ }^{41}$

- Voksne med udviklingshæmning $90 \%$ af alle medarbejdere

- Voksne med psykiske problemer (eks. autisme) $52 \%$ af alle medarbejdere

- Voksne fysisk handicappede $30 \%$ af alle medarbejdere

- Voksne senhjerneskadede $10 \%$ af alle medarbejdere

- Andre ${ }^{42}$ $9 \%$ af alle medarbejdere

\footnotetext{
${ }^{40}$ Undervejs inddrages datakørsel på udsnit af det samlede materiale delt op i mere 'traditionelle' botilbud (uden dagtilbud) i den ene gruppe, og bofællesskaber, opgangsfællesskaber og solistboliger i den anden.

${ }^{41}$ I tabel 2, bilag 3 er mere detaljerede opgørelser.

${ }^{42}$ I skriftlige bemærkninger nævnes her bl.a. demente og scleroseramte
} 
Beboernes/brugernes grad af handicap og funktionsnedsættelser er naturligvis meget varierende, dels fra person til person, dels fra botilbud/afdeling til botilbud, men det er muligt at lave en samlet profil over omsorgsmedhjælpernes og pædagogernes egne vurderinger af beboerne/brugernes funktionsniveau med hensyn til verbal kommunikation, fysisk mobilitet og selvhjulpenhed, idet de i et spørgsmål blev bedt om at plotte ind på en 10-trins skala fra lav til høj.

Samles kategorierne i lav (1-3), middel (4-7) og høj (8-10) tegner der sig følgende billede: ${ }^{43}$

Tabel 3A. Vurdering af den overvejende del af dine beboere/brugeres funktionsniveau i forhold til verbal kommunikation

\begin{tabular}{|l|c|c|c|}
\hline & $\begin{array}{c}\text { Lav } \\
\%\end{array}$ & $\begin{array}{c}\text { Middel } \\
\%\end{array}$ & $\begin{array}{c}\text { Høj } \\
\%\end{array}$ \\
\hline Alle & 37 & 42 & 22 \\
\hline
\end{tabular}

Tabel 3B. Vurdering af den overvejende del af dine beboere/brugeres funktionsniveau i forhold til fysisk mobilitet

\begin{tabular}{|l|c|c|c|}
\hline & $\begin{array}{c}\text { Lav } \\
\%\end{array}$ & $\begin{array}{c}\text { Middel } \\
\%\end{array}$ & $\begin{array}{c}\text { Høj } \\
\%\end{array}$ \\
\hline Alle & 15 & 41 & 43 \\
\hline
\end{tabular}

Tabel 3C. Vurdering af den overvejende del af dine beboere/brugeres funktionsniveau i forhold til selvhjulpenhed

\begin{tabular}{|l|c|c|c|}
\hline & $\begin{array}{c}\text { Lav } \\
\%\end{array}$ & $\begin{array}{c}\text { Middel } \\
\%\end{array}$ & $\begin{array}{c}\text { Høj } \\
\%\end{array}$ \\
\hline Alle & 48 & 40 & 12 \\
\hline
\end{tabular}

Her er tale om subjektive vurderinger, og 'middel' kategorien rummer en talkategori mere end høj/lav, men samlet giver det et indtryk af, at det især på spørgsmålet om selvhjulpenhed, at der er mange svar i den lave ende af skalaen, og mens der generelt er stor overensstemmelse mellem omsorgsmedhjælpernes og pædagogernes vurderinger, er den største forskel mellem de to personalegrupper på netop dette spørgsmål, hvor $55 \%$ af omsorgsmedhjælperne vurderer beboernes selvhjulpenhed som lav $\bmod 47 \%$ af pædagogerne.

En anden Tabel 3 opgørelse er måske mere interessant end den samlede, nemlig om der er markante forskelle i vurderinger af beboernes funktionsniveau blandt personale i botilbud (i mere traditionel forstand) sammenlignet med de mindre enheder i form af bofællesskaber/opgangsfællesskaber/solistboliger.

En særkørsel giver her følgende resultat:

\footnotetext{
${ }^{43}$ I tabel 3A-C, bilag 3, er den mere detaljerede oversigt.
} 
Tabel 3As. Vurdering af den overvejende del af dine beboere/brugeres funktionsniveau i forhold til verbal kommunikation

\begin{tabular}{|l|c|c|c|}
\hline & $\begin{array}{c}\text { Lav } \\
\%\end{array}$ & $\begin{array}{c}\text { Middel } \\
\%\end{array}$ & $\begin{array}{c}\text { Høj } \\
\%\end{array}$ \\
\hline Botilbud & 31 & 49 & 20 \\
\hline $\begin{array}{l}\text { Bofællesskaber } \\
\text { mv. }\end{array}$ & 3 & 73 & 24 \\
\hline
\end{tabular}

Tabel 3Bs. Vurdering af den overvejende del af dine beboere/brugeres funktionsniveau i forhold til fysisk mobilitet

\begin{tabular}{|l|c|c|c|}
\hline & $\begin{array}{c}\text { Lav } \\
\%\end{array}$ & $\begin{array}{c}\text { Middel } \\
\%\end{array}$ & $\begin{array}{c}\text { Høj } \\
\%\end{array}$ \\
\hline Botilbud & 12 & 50 & 38 \\
\hline $\begin{array}{l}\text { Bofællesskaber } \\
\text { mv. }\end{array}$ & 0 & 29 & 71 \\
\hline
\end{tabular}

Tabel 3Cs. Vurdering af den overvejende del af dine beboere/brugeres funktionsniveau i forhold til selvhjulpenhed

\begin{tabular}{|l|c|c|c|}
\hline & $\begin{array}{c}\text { Lav } \\
\%\end{array}$ & $\begin{array}{c}\text { Middel } \\
\%\end{array}$ & $\begin{array}{c}\text { Høj } \\
\%\end{array}$ \\
\hline Botilbud & 47 & 51 & 2 \\
\hline $\begin{array}{l}\text { Bofællesskaber } \\
\text { mv. }\end{array}$ & 10 & 68 & 23 \\
\hline
\end{tabular}

Botilbud med integreret dagtilbud er som nævnt ikke med i denne datakørsel, og det forklarer, at der eksempelvis er færre beboere med lav mobilitet end i den samlede oversigt (idet de typisk er på de større botilbud med dagtilbud), men ellers viser sammenligningen mellem botilbud og bofællesskaber mv., at beboerne i bofællesskaber mv. generelt vurderes med betydeligt højere funktionsniveau end i botilbud. Kun $3 \%$ vurderes at have lavt verbalt kommunikationsniveau mod $31 \%$ i botilbud, og med hensyn til selvhjulpenhed vurderes $10 \%$ at have et lavt funktionsniveau mod $47 \%$ i botilbuddene.

Lav-middel-høj kategorierne er relative forstået på den måde, at der ikke spørges til vurderende sammenligninger i forhold til 'normaltfungerende personer', men i forhold til et generelt fysisk og psykisk omsorgsbehov, og her vurderes behovet altså større i de mere traditionelle botilbud sammenlignet med de mindre bofællesskaber mv.

I næste kapitel dykkes mere specifikt ned i medarbejdernes oplevelser af beboernes måder at fungere i dagligdagen i de bosammenhænge, de indgår i, men først - og afslutningsvist i kapitlet her - skal ses på, om omsorgsmedhjælperne og pædagogerne oplever høje eller lave belastningsgrader i det daglige arbejde, og om de alt i alt er tilfredse med det arbejde, de har? 


\section{Medarbejdernes overordnede syn på arbejdet. 'Tilfredsheds- barometer' og oplevelse af belastningsgrader}

En uomgængelig del af undersøgelser, der har fokus på blandt andet arbejdsmiljø og arbejdsvilkår, er at spørge ind til graden af tilfredshed med jobbet som helhed, og om der opleves større eller mindre belastninger forbundet med det daglige virke.

I spørgeskemaet er en lang række konkrete spørgsmål, der går tæt på de daglige arbejdsopgaver og oplevelse af trivsel i det daglige arbejde. Svarmønstrene beskrives indgående i kapitler 5 og 6, men som rammesætning for de følgende kapitler drages allerede her 'konklusionerne' i form af svarfordelinger på spørgsmålene af typen: "Alt i alt, er du så ...".

Når det drejer sig om botilbud til voksne med udviklingshæmning må tolkning af svarmønstre på spørgsmål om tilfredshed i det daglige arbejde reflektere det massive pres, der generelt har ligget på de professionelle inden for dette område siden de mange mediesager rullede i kølvandet på Bastard Films dokumentarprogram 'Er du åndssvag?' i februar 2007. Et pres på professionen, der kan tænkes at skabe 'forsvarshandlingsmønstre' med overdreven tilfredshed med arbejdet, men på den anden side også give sig udslag i erklæret utilfredshed med arbejdsvilkårene med adresse til ledelse, forvaltning og politikerne som ansvarlige for 'det umulige' i at udføre godt pædagogisk arbejde på grund af fysiske rammer, normering, visitationsprocedurer, mv.

Med dette in mente er de samlede svarmønstre fra deltagerne i undersøgelsen på de fire 'konkluderende' nøglespørgsmål således:

Tabel 24. Tilfredshed med det nuværende arbejde?

\begin{tabular}{|l|c|c|c|c|}
\hline $\begin{array}{l}\text { Er du alt i alt tilfreds med } \\
\text { dit nuværende arbejde? }\end{array}$ & $\begin{array}{c}\text { Ja, i høj } \\
\text { grad } \\
\text { Antal i \% }\end{array}$ & $\begin{array}{c}\text { Ja, i nogen } \\
\text { grad } \\
\text { Antal i \% }\end{array}$ & $\begin{array}{c}\text { Nej, kun i } \\
\text { mindre } \\
\text { grad } \\
\text { Antal i \% }\end{array}$ & $\begin{array}{c}\text { Nej, slet } \\
\text { I kke } \\
\text { Antal i \% }\end{array}$ \\
\hline $\begin{array}{l}\text { Det daglige arbejde med } \\
\text { beboerne/brugerne }\end{array}$ & 63 & 30 & 6 & 1 \\
\hline Arbejdsbetingelserne & 36 & 46 & 16 & 2 \\
\hline
\end{tabular}

En svarfordeling som i tabel 24 efterlader ingen tvivl om, at spørges omsorgsmedhjælpere og pædagoger om deres tilfredshed i det daglige konkrete arbejde sammen med beboerne/brugerne, er den høj. Kun $7 \%$ udtrykker mere eller mindre utilfredshed, og næste to tredjedele erklærer sig 'i høj grad' tilfredse, og svarfordelingen er praktisk talt identisk for de to medarbejdergrupper. Lidt flere pædagoger er 'i høj grad' tilfredse (65 $\%$ ) end omsorgsmedhjælperne (59 \%) men det udlignes af et større antal 'ja, i nogen 
grad' blandt omsorgsmedhjælperne, således at $6 \%$ af dem udtrykker utilfredshed mod $7 \%$ af pædagogerne. ${ }^{44}$

'Tilfredshedsbarometret' er knapt så højt, når spørgsmålet angår arbejdsbetingelserne, men tendenser er også her en overvægt på 'ja-siden' med 36 \% der i høj grad er tilfredse og næsten halvdelen (46\%) der i nogen grad udtrykker tilfredshed. Og stor utilfredshed - som nok er det vigtigste procenttal her - er nede på kun 2 \%. Det gælder for begge medarbejdergrupper, som svarer stort set identisk på spørgsmålet (3 \% flere omsorgsmedhjælpere er 'i nogen grad' tilfredse og tilsvarende $3 \%$ pædagoger er ' $\mathrm{i}$ mindre grad' tilfredse).

I forbindelse med spørgsmålet var der mulighed for at give det en skriftlig kommentar med på vejen, og 30 deltagere gjorde det. Her er typiske bemærkninger:

- Alt for meget arbejde og for lidt tid.

- Vi har meget travlt, mange arbejdsopgaver.

- For dårlig normering.

- Antallet af medhjælpere er steget voldsomt og øger byrden på de fagligt uddannede.

- Lønnen adskiller sig ikke fra almenområdet - hvorfor risikere vold?

I forbindelse med spørgsmålene om oplevelsen af fysiske eller psykiske belastninger samler interessen sig især omkring hvor mange, der oplever dette i nogen eller $h \varnothing j$ grad, og her er det omkring hver fjerde medarbejder, der svarer 'ja' til, at arbejdet opleves som 'noget' eller 'meget' fysisk og psykisk belastende:

Tabel 20. Oplevelse af det psykiske arbejdsmiljø som helhed.

\begin{tabular}{|l|c|c|}
\hline $\begin{array}{l}\text { Oplever du alt i alt at dit } \\
\text { arbejde er psykisk bela- } \\
\text { stende? }\end{array}$ & $\begin{array}{c}\text { Nej, ikke psykisk bela- } \\
\text { stende eller kun lidt } \\
\text { psykisk belastende } \\
\text { Antal i \% }\end{array}$ & $\begin{array}{c}\text { Noget eller meget } \\
\text { psykisk belastende }\end{array}$ \\
\hline Alle & 73 & Antal i \% \\
\hline
\end{tabular}

Tabel 22. Oplevelse af det fysiske arbejdsmiljø som helhed

\begin{tabular}{|l|c|c|}
\hline $\begin{array}{l}\text { Oplever du alt i alt at dit } \\
\text { arbejde er fysisk bela- } \\
\text { stende? }\end{array}$ & $\begin{array}{c}\text { Nej, ikke fysisk bela- } \\
\text { stende eller kun lidt fy- } \\
\text { sisk belastende } \\
\text { Antal i \% }\end{array}$ & $\begin{array}{c}\text { Noget eller meget fysisk } \\
\text { belastende } \\
\text { Antal i \% }\end{array}$ \\
\hline Alle & 75 & 25 \\
\hline
\end{tabular}

Hvorvidt en fjerdedel, der oplever arbejdet fysisk og psykisk belastende vurderes som mange eller få, afhænger af synsvinklen. For en del vil det umiddelbare svar være mange, men på den anden side måske færre end forventet, hvad angår såvel det psykiske arbejdsmiljø (med det ovenfor nævnte 'stormvejr' området har været inde i) som

\footnotetext{
${ }^{44}$ Se de detaljerede opgørelser i bilag 3.
} 
det fysiske (med mange fysisk krævende omsorgsopgaver, der er i forbindelse med en del beboere).

Der er kun små forskelle i svarfordelingen mellem pædagoger og omsorgsmedhjælpere, idet lidt flere omsorgsmedhjælpere oplever arbejdet fysisk belastende (30\% mod $24 \%$ blandt pædagoger), mens lidt flere pædagoger oplever arbejdet psykisk belastende (28\% mod $24 \%$ blandt omsorgsmedhjælpere), og identificeres andelen, der 'slet ikke' oplever belastning, drejer det sig om $33 \%$ i forbindelse med det fysiske, og $14 \%$ i forhold til det psykiske arbejdsmiljø. ${ }^{45}$

En sidste 'tilfredshedspejling' skal medtages her, nemlig en del af svarmønstrene på spørgeskemaets allersidste spørgsmål, der angår forventninger til fremtiden. Her er inddraget et af de 'klassiske' spørgsmål, nemlig "Hvad tror du, du laver om 3 år?" (tabel 35). Svar herpå kan give en pejling på eventuelle ønsker om at skifte arbejdsområde og/eller arbejdsplads.

På spørgsmålet svarer næsten halvdelen af pædagogerne (46\%), at de tror de fortsat arbejder i det botilbud, de i dag er ansat, mens andre $26 \%$ svarer, at de tror de "arbejder inden for området, men et andet sted". Næsten tre ud af fire pædagoger har således en forventning om, at de også om tre år arbejder i botilbud til voksne med udviklingshæmning, og da spørgeskemaunders $\varnothing g e l s e n$ gennemførtes før krisetendenser og et stigende arbejdsløshedstal satte ind, skal forklaringen på dette svarmønster først

\footnotetext{
${ }^{45}$ Spørgsmålene bag tabellerne 24, 20 og 22 er identiske med den tidligere nævnte parallelle landsdækkende omsorgsmedhjælperunders $\varnothing$ gelse, og det er derfor muligt at sammenligne svarmønstrene. Resultatet er tankevækkende, idet der trods relative store forskelle i $ø \varnothing n$, alder, anciennitet og i den landsdækkende unders $\emptyset$ gelse kun deltagelse af omsorgsmedhjælpere, som er spredt over hele landet (og i vid udstrækning i landområder og mindre byer), er der i svarfordelingerne i alle tre tabeller tale om særdeles stor overensstemmelse. Den højeste procentforskel er fire og typisk forskellene 1-2 \%, jf. nedenstående tabeller fra den landsdækkende unders $\emptyset$ gelse med deltagelse af 377 omsorgsmedhjælpere:
}

\begin{tabular}{|c|c|c|c|c|}
\hline $\begin{array}{l}\text { DK Tabel 24. Er du alt i alt tilfreds } \\
\text { med dit nuværende arbejde? }\end{array}$ & $\begin{array}{c}\text { Ja, i høj grad } \\
\text { Antal i \% }\end{array}$ & $\begin{array}{c}\text { Ja, i nogen } \\
\text { grad } \\
\text { Antal i \% }\end{array}$ & $\begin{array}{c}\text { Nej, kun i } \\
\text { mindre grad } \\
\text { Antal i \% }\end{array}$ & $\begin{array}{c}\text { Nej, slet ikke } \\
\text { Antal i \% }\end{array}$ \\
\hline $\begin{array}{l}\text { Det daglige arbejde med beboer- } \\
\text { ne/brugerne }\end{array}$ & 65 & 31 & 3 & 1 \\
\hline Arbejdsbetingelserne & 34 & 49 & 15 & 3 \\
\hline $\begin{array}{l}\text { DK Tabel 20. Oplevelse af det } \\
\text { psykiske arbejdsmiljø som helhed }\end{array}$ & \multicolumn{2}{|c|}{$\begin{array}{c}\text { Nej, ikke eller kun lidt psykisk } \\
\text { belastende Antal i \% }\end{array}$} & \multicolumn{2}{|c|}{$\begin{array}{c}\text { Noget eller meget psykisk bela- } \\
\text { stende. Antal i \% }\end{array}$} \\
\hline $\begin{array}{l}\text { Oplever du alt i alt at dit arbejde er } \\
\text { psykisk belastende? }\end{array}$ & \multicolumn{2}{|c|}{72} & \multicolumn{2}{|c|}{28} \\
\hline $\begin{array}{l}\text { DK Tabel 22. Oplevelse af det } \\
\text { fysiske arbejdsmiljø som helhed }\end{array}$ & \multicolumn{2}{|c|}{$\begin{array}{l}\text { Nej, ikke eller kun lidt fysisk } \\
\text { belastende. Antal i \% }\end{array}$} & \multicolumn{2}{|c|}{$\begin{array}{l}\text { Noget eller meget fysisk bela- } \\
\text { stende. Antal i \% }\end{array}$} \\
\hline $\begin{array}{l}\text { Oplever du alt i alt at dit arbejde er } \\
\text { fysisk belastende? }\end{array}$ & \multicolumn{2}{|c|}{71} & \multicolumn{2}{|c|}{29} \\
\hline
\end{tabular}


og fremmest findes $\mathrm{i}$, at der er tale om en medarbejdergruppe, der oplever sig dedikeret til den type job, de aktuelt varetager. ${ }^{46}$

Knap så høje procenttal finder man hos omsorgsmedhjælperne, men det er her trods alt halvdelen (49\%), der tror de arbejder inden for samme område, fordelt med 39 \% på samme sted og $10 \%$ på en anden tilsvarende arbejdsplads. ${ }^{47}$

Samlet tegner der sig et billede af en i det store og hele tilfreds medarbejderstab inden for botilbud til voksne med udviklingshæmning og/eller fysiske handicap, og tillige en 'trofast' medarbejdergruppe uden de store planer om at droppe arbejdsområdet for at søge helt nye græsgange.

Det antyder umiddelbart, at der blandt en stor del af de deltagende pædagoger og omsorgsmedhjælpere er en stemning af at udføre arbejdet godt (eller i det mindste tilfredsstillende) og at genvordigheder med egensindige eller 'genstridige' beboere o.l. muligvis ikke opleves helt så markant, som det af og til fremstilles i medier og internt i professionsmiljøet. Herom handler næste kapitel.

\footnotetext{
${ }^{46}$ Yderligere kan tilføjes, at $8 \%$ er i en så høj alder, at de tror/ved, at de om 3 år har afsluttet deres aktive arbejdsliv og er efterlønnere eller pensionister, så samlet er det kun hver femte, der tror de er under videregående uddannelse, på barsel, i en anden type arbejde eller 'laver noget helt andet'.

${ }^{47}$ Af andre muligheder tror her $20 \%$ at de er under uddannelse til pædagog eller andet, mens $22 \%$ tror de har andet arbejde uden for botilbudsområdet.
} 


\section{Kapitel 3}

\section{Det gode liv i egen bolig, etiske dilemmaer og vanskelige beboere. Myte eller fakta?}

Mens det senere kapitel 5 giver et detaljeret indblik i hvilke praktiske arbejdsopgaver og pædagogiske funktioner, medarbejderne i botilbud konkret har, er temaet i kapitel 3 indblikket i, hvordan pædagoger og omsorgsmedhjælpere som helhed oplever det daglige arbejde, de beboere, de arbejder (sammen) med og deres arbejdspladskultur $\mathrm{i}$ forhold til de krav og forventninger, der rummes i kraft af lovgivningen, beboernes væremåder og pårørendes medinddragelse. Subjektive synspunkter og individuelle professionelle erfaringer er således i centrum, og målet er at formidle indblikket i, hvordan medarbejderne oplever deres daglige professionelle arbejde som ansatte i et botilbud og de beboere/brugere, de møder.

\section{Pejlemærker på 'et godt liv' i egen bolig}

Som omtalt i kapitel 1 var Socialministeriet i 2007 udgiver af rapporten 'Veje til et godt liv i egen bolig'. Anledningen var en reaktion på de 'afsløringer' af omsorgssvigt og 'forråelse' i botilbud, som prægede medierne i årets første måneder, og rapporten er et policy-paper udarbejdet af en arbejdsgruppe med deltagelse af repræsentanter fra $\mathrm{KL}$, Danske Regioner, de centrale personaleorganisationer (SL, FOA og 3F), DSI og Socialministeriet.

I rapporten opridser arbejdsgruppen blandt andet en række pejlemærker for et godt liv i botilbud (side 10ff), altså forslag til en form for 'kvalitetsindeks' bestående af 11 pejlemærker for om en beboer "har mulighed for et godt liv på egne præmisser $i$ botilbud" (side 5). Ni af pejlemærkerne dannede i lettere sprogligt revideret form grundstammen i et af spørgeskemaets mange spørgsmål ('politisk bevågenhed' udladedes, da det ikke direkte angår dagligdagen i botilbud, og 'rumme forskellighed og håndtere forskellig rummelighed' ligeså, da det forekom en anelse for kryptisk formuleret). ${ }^{48}$

Spørgsmål 10 formuleredes således: "I rapporten 'Veje til et godt liv i egen bolig' opridses en række pejlemærker for beboernes "mulighed for et godt liv på egne præmisser i botilbud." Hvor vil du indplacere det botilbud/den afdeling, du er tilknyttet, $i$ forhold til graden af målopfyldelse på følgende spørgsmål?" De samlede svarfordelinger er:

\footnotetext{
${ }^{48}$ I kapitel 8 vendes tilbage til et andet spørgsmål formuleret med reference til 'Veje til et godt liv i egen bolig'.
} 
Tabel 10. Bostedets muligheder for at skabe gode rammer om beboernes dagligliv ${ }^{49}$

\begin{tabular}{|c|c|c|c|c|c|}
\hline $\begin{array}{l}\text { Bostedets muligheder for at skabe go- } \\
\text { de rammer om beboernes dagligliv }\end{array}$ & $\begin{array}{c}\text { Me- } \\
\text { get } \\
\text { høj } \\
\text { Antal } \\
\text { i \% }\end{array}$ & $\begin{array}{c}\text { Høj } \\
\text { Antal } \\
\text { i \% }\end{array}$ & $\begin{array}{c}\begin{array}{c}\text { Mid- } \\
\text { del }\end{array} \\
\begin{array}{c}\text { Antal } \\
\text { i } \%\end{array} \\
\end{array}$ & $\begin{array}{l}\text { Antal } \\
\text { i \% }\end{array}$ & $\begin{array}{c}\text { Me- } \\
\text { get } \\
\text { lav } \\
\text { Antal } \\
\text { i \% }\end{array}$ \\
\hline $\begin{array}{l}\text { Beboernes selvbestemmelse og indflydelse } \\
\text { på eget liv }\end{array}$ & 17 & 37 & 27 & 11 & 8 \\
\hline $\begin{array}{l}\text { Beboernes oplevelse af at have eget hjem } \\
\text { og privatliv ("råderum og roderum") }\end{array}$ & 23 & 31 & 25 & 11 & 9 \\
\hline $\begin{array}{l}\text { Beboernes muligheder for at kommunikere } \\
\text { på egne betingelser }\end{array}$ & 21 & 45 & 23 & 7 & 4 \\
\hline $\begin{array}{l}\text { Beboernes daglige stimuli: Udfordringer i } \\
\text { forhold til individuelle ønsker og behov }\end{array}$ & 10 & 29 & 46 & 12 & 3 \\
\hline $\begin{array}{l}\text { Beboernes indflydelse på, hvor de bor og } \\
\text { hvem de bor sammen med }\end{array}$ & 3 & 8 & 17 & 18 & 54 \\
\hline Beboernes oplevelse af tryghed i hjemmet & 19 & 42 & 28 & 8 & 3 \\
\hline $\begin{array}{l}\text { Bostedets evne til at skabe plads til spon- } \\
\text { tanitet i hverdagen med beboerne/brugerne }\end{array}$ & 6 & 24 & 44 & 17 & 8 \\
\hline $\begin{array}{l}\text { En kultur på arbejdspladsen præget af } \\
\text { åbenhed og respekt samt etik og værdier }\end{array}$ & 29 & 44 & 18 & 5 & 3 \\
\hline $\begin{array}{l}\text { Faglighed i den pædagogiske indsats som } \\
\text { helhed }\end{array}$ & 27 & 44 & 20 & 6 & 2 \\
\hline
\end{tabular}

Et blik nedover tabellen peger på, at når pædagoger og omsorgsmedhjælpere skal beskrive deres botilbuds 'rummelighed' og egen faglighed og arbejdspladskultur, er 'kvaliteten' høj, og kun under to spørgsmål er andelen af 'under middel' svar ('lav' eller 'meget lav') over $20 \%$, nemlig i spørgsmålet om plads til spontanitet i hverdagen (25 \%), og så - ikke helt uventet - på spørgsmålet om brugernes indflydelse på valg af egen bolig. Et af de centrale spørgsmål i lyset af Servicelovens intentioner, og i undersøgelsen her bekræftes det underskud af muligheder i forbindelse med eget valg af bolig, som er beskrevet i kapitel 1. Næsten tre ud af fire medarbejdere (72 \%) sætter kryds ved 'under middel' svarmulighederne, og blot $11 \%$ over.

Men på de $\varnothing$ vrige spørgsmål er svarmønstrene omvendte. Drejer det sig om 'faglighed' og en arbejdsplads præget af 'åbenhed og respekt samt etik og værdier', mener knapt hver tredje, at den er 'meget høj', og over $70 \%$ at den er 'over middel' (mens kun $8 \%$ mener den er under).

\footnotetext{
${ }^{49}$ I denne og de følgende tabeller, der angår medarbejdernes vurderinger og synspunkter, er kun medtaget svardata fra dem, der tager aktivt stilling til spørgsmålene, dvs. kolonnerne 'Ved ikke' og 'Denne faktor er ikke relevant for mig' (ift. mine arbejdsopgaver) er 'neutraliseret'. I tabellen her ligger procentdelen 'Ved ikke' typisk på 0 eller 1, og kun i et tilfælde er den over $2 \%$, nemlig på spørgsmålet om beboernes indflydelse på, hvem de vil bo sammen med. Her er andelen $7 \%$, formentligt fordi de pågældende respondenter kun har sporadisk indsigt i denne problemstilling. I bilag 3 er samtlige data opgjort i de respektive tabeller.
} 
Kun under et af spørgsmålene (udover spontanitet og boligvalg) er andelen af svar 'middel' eller derunder over $50 \%$, nemlig 'Udfordringer i forhold til individuelle $\emptyset$ nsker og behov' (61 \%), og selv på spørgsmålet 'Beboernes selvbestemmelse og indflydelse på eget liv', der kan siges at have et vist 'slægtskab' med spørgsmålet om indflydelse på eget boligvalg, er barometret 'over middel' (54 \%).

Sammenlignes svarmønstre fra henholdsvis pædagoger og omsorgsmedhjælpere (se bilag 3) er der ingen markante forskelle. Slås kategorier sammen i 'høj', 'middel' og 'lav' er forskellene stort set alle på under fire procentpoint, og kun under tre spørgsmål er variationen under svarkategorien over middel ('meget $h \varnothing j / h ø j$ ') over fem procent, nemlig spørgsmålet om 'Beboernes daglige stimuli' (udfordringer), hvor 40 \% pædagoger mod 34 \% omsorgsmedhjælpere mener den er 'over middel', på spørgsmålet om botilbuddets evne til at skabe spontanitet, hvor pædagogerne også er de mest positive i deres selvforståelse (33 \% 'meget $h \varnothing j / h ø j$ ' mod $24 \%$ blandt omsorgsmedhjælpere), og så endelig spørgsmålet om beboernes oplevelse af tryghed, hvor rollerne er bygget om, idet $70 \%$ af omsorgsmedhjælperne her mener den er 'meget høj' eller 'høj', mens 'kun' $58 \%$ af pædagogerne mener det samme.

Det samlede billede er, at når medarbejderne i de 22 deltagende botilbud spørges ind til deres egen vurdering af deres botilbuds 'status' i forhold til 9 af de 11 pejlemærker for beboernes mulighed for et godt liv på egne præmisser, som arbejdsgruppen bag rapporten 'Veje til et godt liv i egen bolig' er nået frem til som centrale, er der ingen 'alarmklokker' som ringer. Generelt vurderes botilbudskulturens indfrielse af pejlemærker som disse 'højt' og 'meget højt', og kun på to pejlemærker vurderes 'under middel' til at være over $25 \%$, og især retten til eget boligvalg er her højdespringeren med 72 \% under 'middel' - og her må tages med i vurderingen, at det er et af de spørgsmål, hvor det enkelte botilbud næppe i sig selv og af sig selv har de store muligheder for at ændre vilkårene for beboernes mobilitet.

Svarmønstrene i tabel 10 giver umiddelbart forventning om, at når der dykkes lidt tættere ned i dagliglivet i botilbuddene og spørges ind til pædagogerne og omsorgsmedhjælpernes vurdering af 'vanskelige situationer', problematiske beboere og etiske dilemmaer i dagligdagen, er situationen knap så dyster, som mediernes beskrivelser af forholdene på enkelte situationer kan give indtryk af, eller som nogle af de problembeskrivelser, der cirkulerer i socialpædagogiske kredse, antyder. Hvordan dette forholder sig i forhold til udvalgte temaer, er emnet i næste afsnit. 


\section{Synspunkter på det daglige arbejde, herunder etiske dilem- maer, vanskelige beboere og samarbejdet med pårørende}

Forud for udarbejdelsen af de af spørgeskemaets spørgsmål, der har fokus på medarbejdernes synspunkter og vurderinger af indsatsen i botilbud og samspillet mellem beboere og pædagogisk personale og beboerne imellem gennemførtes en række interviewsamtaler med 'garvede' medarbejdere inden for området for at identificere, hvordan 'vanskelige beboere', etiske dilemmaer og andre særlige kendetegn ved dagligdagen i botilbud italesættes i personalegrupperne.

Herudfra konstrueredes en række 'erfaringsorienterede' konkrete spørgsmål, dels af karakteren "Hvad er dit synspunkt på ...?" med svarspektret 'enig-uenig', dels beskrivelser af en række pædagogisk 'vanskelige pædagogiske' med svarspektret 'oftesjældent' forekommende, og endelig nogle spørgsmål omkring oplevelsen af 'psykisk belastende' situationer med svarspektret 'i høj grad-slet ikke'.

I alt mere en 30 konkrete underspørgsmål til stillingtagen, og det er svarmønstrene på disse, der på de følgende side er 'brudt op' og tematiseret i syv grupperinger:

- Etiske dilemmaer?

- Omsorg og trivsel

- De daglige rutiner

- Ud af huset aktiviteter

- Aggressive beboere og fysiske konflikter

- Samarbejde med de pårørende

- Samarbejde og kontinuitet i det pædagogiske arbejde

\section{Etiske dilemmaer?}

Man skal ikke opholde sig længe i botilbudsmiljøer til voksne med udviklingshæmning eller læse sig ind på området, før begrebet 'etiske dilemmaer' popper op. Typisk beskrevet som en slags juridisk 'spin-off', idet 'Lov om social service' med tilhørende vejledninger på samme tid pålægger den pædagogisk handlende et omsorgsansvar (den nødvendige omsorg skal varetages, om nødvendigt med magt), og en samtidig anerkendelse af beboerens/brugerens suveræne integritet (der må ikke handles mod 'borgerens udtrykte interesse'), og denne dobbelte fordring til professionel handlen udmøntes så i et dilemma. En populær definition på et etisk dilemma inden for arbejdet med voksne med udviklingshæmning lyder således: "Der kan opstå et etisk dilemma, så snart du har pligt til at gøre mere end én ting. Når du har mere end én pligt, er der mulighed for, at pligterne kommer i konflikt med hinanden. Når du opfylder den ene pligt umuliggør du den anden - og omvendt." (Kayser 2005:13).

Spørges direkte til, om medarbejderne ofte oplever 'etiske dilemmaer' er svaret klart bekræftende. $40 \%$ er 'helt enige' i, at det gør de ofte, mens $45 \%$ er 'delvist enige', og kun 15 \% er 'uenig' eller 'helt uenig', som det fremgår af uddraget af tabel 25. 
Tabel 25. Synspunkter på den pædagogiske dagligdag (uddrag)

\begin{tabular}{|l|c|c|c|c|}
\hline $\begin{array}{l}\text { Synspunkter på den pædagogiske daglig- } \\
\text { dag }\end{array}$ & $\begin{array}{c}\text { Helt } \\
\text { enig } \\
\text { Antal i } \\
\%\end{array}$ & $\begin{array}{c}\text { Delvis } \\
\text { enig } \\
\text { Antal i } \\
\%\end{array}$ & $\begin{array}{c}\text { Uenig } \\
\text { Antal i } \\
\%\end{array}$ & $\begin{array}{c}\text { Helt } \\
\text { uenig } \\
\text { Antal i } \\
\%\end{array}$ \\
\hline $\begin{array}{l}\text { I dagligdagen oplever personalet ofte 'etiske } \\
\text { dilemmaer' mellem forskellige pædagogiske } \\
\text { hensyn ift. den enkelte beboer/bruger (f.eks. } \\
\text { beboer/brugers krav om 'usund mad' og pæ- } \\
\text { dagogisk omsorgspligt) }\end{array}$ & 40 & 45 & 12 & 3 \\
\hline
\end{tabular}

Ses der efter eventuelle forskelle i svarmønstre mellem omsorgsmedhjælper- og pædagoggruppen er der en markant større andel omsorgsmedhjælpere (23\%), der er 'uenig' eller 'helt uenig' sammenlignet med pædagoggruppen (12\%). Næsten dobbelt så mange (i procent) omsorgsmedhjælpere kan ikke nikke genkendende til, at der ofte forekommer 'etiske dilemmaer' i det daglige arbejde. Det kan skyldes en anden opgaveprofil (se kapitel 5), eller at det er et af de områder, hvor den pædagogiske faglige professionsforståelse er forskellig mellem pædagogiske uddannede og ikke-uddannede. En mulig tolkning, der bestyrkes, når andelen, der svarer 'ved ikke' tages med. I tabeller som tabel 25 er som tidligere nævnt kun de medarbejdere, der tager aktivt stilling til spørgsmålene, medtaget i tabellen, der således er korrigeret for 'ved ikke', og på spørgsmålet om 'etiske dilemmaer' er den andel blandt omsorgsmedhjælperne, der svarer 'ved ikke' den tredje største, nemlig 17 \% (mod 4 \% blandt pædagogerne).

Men hvad så med eventuelle forskelle mellem de mere 'traditionelle' botilbud og de mindre bofællesskaber mv.? På ny 'renset' for 'ved ikke' (henhv. 3 og 8 \%) er andelen fra begge døgntilbudskategorier, der er 'delvist enige' $38 \%$, men der er stor forskel på andelen, der er 'helt enige'. 59 \% i bofællesskaber mv. er 'helt enige' i, at de ofte står med 'etiske dilemmaer' mod $42 \%$ blandt personalet i botilbud, og i den anden ende af skalaen er således 20 \% fra botilbud, der er 'uenig eller helt uenig' mod kun 3 \% fra bofællesskaber mv. Et forsigtigt bud på en mulig forklaring på disse forskelle kan være en højere grad af en 'institutionaliseret dagligdag' i de typisk lidt større botilbud som ikke kræver så mange ad hoc beslutninger, hvor der er flere mulige valg at træffe og dermed mulighed for at stå i etiske dilemmaer. En tolkning der bestyrkes af, at i den samlede tabel er der lavere andel 'helt enig' (40\%) end i de to grupperinger i særkørslen, og i den er som tidligere nævnt kun medtaget 'rene' botilbud, hvilket betyder, at botilbud med integreret dagtilbud ikke er med, og de hører til blandt de botilbud $\mathrm{i}$ unders $\varnothing$ gelsen, der er størst. 


\section{Omsorg og trivsel}

Et andet spørgsmål kan indirekte knyttes sammen med oplevelsen af 'etiske dilemmaer'. Generelt kan antages, at jo højere grad af refleksiv kognitiv kapacitet og verbal kommunikationsberedskab en beboer/bruger besidder, desto flere situationer i det daglige samspil med flere valgmuligheder vil finde sin løsning i aktiv kommunikativ dialog mellem medarbejder og bruger, og omvendt, jo mindre verbalt og refleksivt, brugeren har mulighed for at kommunikere, desto flere valg og beslutninger, må medarbejderen træffe på et af den pædagogiske professions vanskeligste områder: tolkning af $\varnothing$ nsker og interesser på brugerens vegne uden at de direkte kan verificeres af hende.

Under et af spørgsmålene om psykiske belastninger i det daglige arbejde spørges ind til, om det opleves som en psykisk belastning, at der er vanskeligheder forbundet med at tolke beboerens/brugerens ønsker og behov på grund af kommunikative vanskeligheder. Svarmønstrene peger dog ikke i retning, af at der opleves massive vanskeligheder hermed:

Tabel 21. Belastende psykiske faktorer i arbejdet (uddrag)

\begin{tabular}{|l|c|c|c|c|}
\hline $\begin{array}{l}\text { Belastende psykiske faktorer i } \\
\text { arbejdet }\end{array}$ & Slet ikke & $\begin{array}{c}\text { I mindre } \\
\text { grad } \\
\text { Antal i \% }\end{array}$ & $\begin{array}{c}\text { I nogen } \\
\text { grad } \\
\text { Antal i \% }\end{array}$ & $\begin{array}{c}\text { I høj } \\
\text { grad } \\
\text { Antal i \% }\end{array}$ \\
\hline $\begin{array}{l}\text { Svært at tolke beboerne/brugernes } \\
\text { ønsker og behov pga. kommunika- } \\
\text { tionsvanskeligheder }\end{array}$ & 22 & 41 & 27 & 10 \\
\hline
\end{tabular}

Lidt over en femtedel (22\%) mener 'slet ikke' at eventuelle tolkningsvanskeligheder opleves psykisk belastende, mens kun $10 \%$ i den anden ende svarer 'i høj grad', og samlet svarer næsten to tredjedel (63\%) 'slet ikke' eller kun 'i mindre grad'.

Dette indtryk kan sammenholdes med den tidligere inddragne tabel 3, hvor samlet 37 \% beskrev beboernes verbale kommunikation til at ligge i 'den lave ende' af skalaen fra 1 til 10, men her kunne iagttages store forskelle på henholdsvis botilbud (uden dagtilbud) hvor $41 \%$ vurderer den verbale kommunikation i den lave ende mod blot $3 \%$ inden for bofællesskaber mv. Ses efter tilsvarende forskelle mellem de to grupper i forhold til tabel 21 viser der sig en mindre forskel. Mens $26 \%$ i botilbud svarer 'slet ikke' er det 32 \% i bofællesskaber mv., mens - i den anden ende af spektret - 9 \% i botilbud svarer 'i høj grad' mod $0 \%$ i bofællesskaber mv. Da procenttallene her ligger under det samlede (10\%) kan udledes, at det er i botilbud med tilknyttede dagtilbud, der er den højeste andel, der svarer 'i høj grad', men samlet peger svarmønstrene på, at det ikke opleves som et meget stort og psykisk belastende problem at tolke beboernes ønsker og behov.

En anden central side af den daglige omsorg og beboertrivsel er spørgsmål omkring, hvorvidt der opleves at være den 'nødvendige tid' til samvær, omsorg og hensyn til de 
enkelte beboere, og om beboerne opleves at trives sammen. Tabel 25 rummer nogle spørgsmål herom:

Tabel 25. Synspunkter på den pædagogiske dagligdag (uddrag)

\begin{tabular}{|c|c|c|c|c|}
\hline $\begin{array}{l}\text { Synspunkter på den pædagogiske daglig- } \\
\text { dag }\end{array}$ & $\begin{array}{c}\text { Helt } \\
\text { enig } \\
\text { Antal } \\
\text { i \% }\end{array}$ & $\begin{array}{c}\text { Del- } \\
\text { vis } \\
\text { enig } \\
\text { Antal } \\
\text { i } \%\end{array}$ & $\begin{array}{c}\text { Uenig } \\
\begin{array}{c}\text { Antal i } \\
\%\end{array}\end{array}$ & $\begin{array}{c}\text { Helt } \\
\text { uenig } \\
\text { Antal i } \\
\%\end{array}$ \\
\hline $\begin{array}{l}\text { I almindelighed er der den nødvendige tid til } \\
\text { den daglige omsorg i forhold til de enkelte } \\
\text { beboere/brugere }\end{array}$ & 23 & 49 & 22 & 6 \\
\hline $\begin{array}{l}\text { I dagligdagen tages der tilpas hensyn til den } \\
\text { enkelte beboer/brugers individuelle ønsker } \\
\text { mht. mad, privatliv, mv. }\end{array}$ & 30 & 52 & 13 & 5 \\
\hline $\begin{array}{l}\text { På bostedet/afdelingen tages der tilstrækkeligt } \\
\text { hensyn til de enkelte beboeres/brugeres indi- } \\
\text { viduelle livsrytmer og daglige rutiner }\end{array}$ & 36 & 50 & 11 & 3 \\
\hline $\begin{array}{l}\text { De beboere/brugere, der lige nu er på boste- } \\
\text { det/dagtilbuddet, fungerer som helhed godt } \\
\text { sammen med hinanden i dagligdagen }\end{array}$ & 17 & 43 & 26 & 14 \\
\hline
\end{tabular}

En del pædagoger og omsorgsmedhjælpere - $28 \%$ - er 'uenig' eller 'helt uenig' i, at der i det daglige er den nødvendige tid til omsorgen for de enkelte beboere, men næsten lige så mange ( $23 \%$ ) er 'helt enige' $\mathrm{i}$, at der er den nødvendige tid til rådighed, og halvdelen (49 \%) er således 'delvist enige'. Lidt mere positivt er indtrykket, når der spørges til, om der tages tilpasse hensyn til de enkelte beboeres individuelle livsrytmer, rutiner og konkrete ønsker til for eksempel mad. Omkring hver tredje medarbejder mener her, at der fuldt ud tages individuelt tilpassede hensyn, mens halvdelen er 'delvist enige'. I den anden ende af skalaen er det $18 \%$, der er helt eller delvist uenige $\mathrm{i}$ at der tages tilpasse hensyn til individuelle ønsker, og $14 \%$ tilsvarende i forhold til hensyn til beboernes livsrytme og rutiner.

Mere negativ er vurderingen af beboernes trivsel indbyrdes. Betydeligt færre pædagoger og medarbejdere (17\%) er her 'helt enige' $i$, at beboerne som helhed fungerer godt sammen, mens næsten lige så mange (14 \%) er helt uenige heri og en fjerdedel (26\%) delvist uenige, men det samlede billede er, at flertallet (60\%) er helt eller delvist enige $i$, at beboerne fungerer godt sammen med hinanden i dagligdagen.

En anden pejling af beboernes trivsel i det daglige er, om mange beboere opleves at isolere sig eller virker 'fraværende' eller måske fysisk skader sig selv.

Selvom de fleste pædagoger og omsorgsmedhjælpere på disse spørgsmål svarer sjældent eller meget sjældent, er det dog en ganske stor del, der svarer 'ofte', som det fremgår af tabel 26: 
Tabel 26. Pædagogisk 'vanskelige situationer' (uddrag)

\begin{tabular}{|l|c|c|c|c|}
\hline Pædagogisk 'vanskelige situationer' & $\begin{array}{c}\text { Meget } \\
\text { ofte } \\
\text { Antal i } \\
\%\end{array}$ & $\begin{array}{c}\text { Ofte } \\
\text { Antal i } \\
\%\end{array}$ & $\begin{array}{c}\text { Sjæl- } \\
\text { dent } \\
\text { Antal i } \\
\%\end{array}$ & $\begin{array}{c}\text { Meget } \\
\text { sjæl- } \\
\text { dent } \\
\text { Antal i } \\
\%\end{array}$ \\
\hline $\begin{array}{l}\text { Beboerne, som isolerer sig alt for meget på } \\
\text { eget værelse/lejlighed }\end{array}$ & 8 & 33 & 43 & 16 \\
\hline $\begin{array}{l}\text { Beboere/ brugere som virker 'fraværende' } \\
\text { (apatiske) og er svære at komme i kontakt } \\
\text { med }\end{array}$ & 3 & 27 & 46 & 24 \\
\hline $\begin{array}{l}\text { Beboere/ brugere som fysisk skader sig selv } \\
\text { ('selvskadende virksomhed') }\end{array}$ & 6 & 27 & 37 & 30 \\
\hline
\end{tabular}

Fire ud af ti medarbejdere oplever, at de arbejder i bosteder, hvor der er beboere, som ofte eller meget ofte isolerer sig for meget i 'privaten', og kun $16 \%$ mener, at det sker 'meget sjældent'. Under spørgsmål som dette skal med, at der ikke 'blot' spørges til om det opleves at ske ofte eller sjældent, men om det - hvis det sker ofte - opleves som en pædagogisk 'vanskelig situation', som der underforstået bør arbejdes pædagogisk for at imødegå, og dette ser - vurderet ud fra svarfordelingen - ud til at være hyppigt forekommende.

Knapt så ofte opleves det at være en pædagogisk vanskelig situation, når det drejer sig om en eller flere beboere, som virker mentalt fraværende og svære at komme i kontakt med, men der er dog tale om en relativ $h \emptyset j$ andel medarbejdere, der sætter kryds ved 'ofte' eller 'meget ofte'; nemlig knap en tredjedel (30\%, mens en fjerdedel svarer 'meget sjældent'), og når der spørges ind til, om der er beboere, der direkte er tilbøjelige til selvskadende virksomhed, er procentdelen af medarbejdere, der svarer ofte eller meget ofte oppe på en tredjedel (33\%) eller lidt flere end dem, der svarer 'meget sjældent' (30\%).

Et samlet billede på otte spørgsmål, der angår omsorg og trivsel, der kan tolkes på flere måder. Et flertal pædagoger og omsorgsmedhjælpere mener, at der i det store og hele er tid til den daglige individuelt rettede omsorg, at der tages tilstrækkelige hensyn til de enkelte beboeres egenhed mv., men på den anden side er der tale om relativt høje andele, der markerer i 'den negative ende'. Over en tredjedel oplever kommunikationsvanskeligheder ifm. tolkning af beboernes ønsker og behov som mere eller mindre psykisk belastende, omkring hver femte mener, der burde være mere tid til den enkelte beboer i det daglige, fire ud af ti medarbejdere markerer, at det daglige samspil beboerne imellem ikke er gnidningsfrit, og samme andel oplever beboerisolation som et pædagogisk problem. Endeligt beskriver omkring en tredjedel, at apatiske beboere og beboere, der er tilbøjelige til at skade sig selv fysisk er ofte eller meget ofte forekommende. 


\section{De daglige rutiner}

Dagligdagen på bostederne rummer som i ethvert andet hjem en række dagligt tilbagevendende begivenheder med spisning, hygiejne og nattes $\varnothing \mathrm{vn}$ som nogle af de, der ofte høres omtalt som problematiske i forhold til nogle beboere i botilbud. Beboere, der har svært ved at overholde de uskrevne regler omkring spisebordet, eller som har vanskeligt ved at følge daglige rutiner omkring at gå i seng og stå op.

En række spørgsmål handler om, hvorvidt sådanne dagligdags situationer opleves vanskelige i pædagogisk henseende, og det samlede indtryk af otte situationsspørgsmål er, at dagligdagen i al almindelighed ikke er domineret af store problemer i så henseende:

Tabel 26. Pædagogisk 'vanskelige situationer' (uddrag)

\begin{tabular}{|l|c|c|c|c|}
\hline Pædagogisk 'vanskelige situationer' & $\begin{array}{c}\text { Meget } \\
\text { ofte } \\
\text { Antal i } \\
\%\end{array}$ & $\begin{array}{c}\text { Ofte } \\
\text { Antal i } \\
\%\end{array}$ & $\begin{array}{c}\text { Sjæl- } \\
\text { dent } \\
\text { Antal i } \\
\%\end{array}$ & $\begin{array}{c}\text { Meget } \\
\text { sjæl- } \\
\text { dent } \\
\text { Antal i } \\
\%\end{array}$ \\
\hline $\begin{array}{l}\text { Måltiderne (eksempelvis beboere/brugere, } \\
\text { som ikke vil spise det, der er på bordet, går til } \\
\text { og fra bordet o.l.) }\end{array}$ & 7 & 23 & 43 & 28 \\
\hline $\begin{array}{l}\text { Beboer/brugerønsker om mad m.v. 'mellem } \\
\text { måltiderne', som ikke kan imødekommes }\end{array}$ & 6 & 14 & 47 & 33 \\
\hline $\begin{array}{l}\text { Gå i seng situationer (eksempelvis hvis beboe- } \\
\text { ren ikke vil gå i seng) }\end{array}$ & 3 & 13 & 49 & 35 \\
\hline $\begin{array}{l}\text { Stå op situationer (eksempelvis hvis beboeren } \\
\text { ikke vil stå op) }\end{array}$ & 2 & 18 & 46 & 33 \\
\hline $\begin{array}{l}\text { 'Nattevandringer' (eksempelvis står op midt } \\
\text { om natten og forstyrrer andre beboere) }\end{array}$ & 3 & 22 & 43 & 32 \\
\hline $\begin{array}{l}\text { Modstand mod hygiejneomsorg (bade, børste } \\
\text { tænder m.m. sammen med beboeren) }\end{array}$ & 5 & 25 & 41 & 28 \\
\hline Modstand mod at tage lægeordineret medicin & 2 & 6 & 38 & 54 \\
\hline $\begin{array}{l}\text { Beboere/brugere som kræver at få udleveret } \\
\text { egne penge, som vurderes vil blive 'klattet } \\
\text { væk' }\end{array}$ & 3 & 12 & 33 & 52 \\
\hline
\end{tabular}

Omkring spisning - enten problemer rundt om spisebordet eller beboere der ønsker 'mellemmåltider', der ikke kan efterkommes - opleves som meget sjældent forekommende af omkring en tredjedel af medarbejderne (28\% og $33 \%$ ), og 'sjældent' af knapt halvdelen (43\% og $47 \%$ ). Samlet markerer $71 \%$, at problemer under de fælles måltider kun undtagelsesvist giver anledning til pædagogisk vanskelige situationer, mens $80 \%$ mener tilsvarende omkring uindfrielige beboerønsker om mellemmåltider. Kun 7 \% sætter kryds ved, at problematiske spisesituationer er 'meget ofte' forekommende.

Når spørgsmålene angår natterutiner er andelen, der ofte oplever problemer i den forbindelse endnu mindre. $3 \%$ mener, der 'meget ofte' er vanskeligheder i tilknytning til at gå i seng og og $2 \%$ omkring stå op rutiner, mens $3 \%$ ofte oplever 'nattevan- 
dring $^{\prime 50}$, og i den anden ende af skalaen er det mere end tre ud af fire pædagoger og omsorgsmedhjælpere, der mener pædagogiske vanskelige situationer er sjældent eller meget sjældent forekommende.

Et næsten tilsvarende billede tegner sig, når spørgsmålet angår den daglige hygiejneomsorg og eventuelt vanskelige situationer omkring tandbørstning, badning mv. Her er dog en lidt større andel - $30 \%$ - der mener at der ofte eller meget ofte er pædagogisk vanskelige situationer, men fortsat altså en majoritet på 70 \% der oplever, at problemer i den forbindelse er undtagelser.

Endelig er der i denne 'buket' af spørgsmål i forbindelse med de daglige rutiner et omkring et tema, som ikke sjældent gøres til genstand for et 'etisk dilemma' i case-beskrivelser, nemlig beboernes råderet over egne penge. Det er deres egne og principielt har de dispositionsretten, men på den anden side er der for mange beboeres vedkommende erfaringer med, at de ikke kan styre den daglige økonomi selv og derfor risikerer at 'klatte' pengene væk, hvis de har dem i hånden.

Ud af det samlede antal svar, er der her to tredjedel af medarbejderne, der har erfaringer i forhold hertil (34 \% svarede 'Ikke aktuelt for mig/ved ikke'), og at dømme efter svarmønstrene, er pædagogisk vanskelige situationer i forholdelse med 'privatøkonomisk forvaltning' ikke hyppigt forekommende. Mere end halvdelen (52 \%) mener problemer er meget sjældent forekommende og kun $3 \%$, at de 'meget ofte' er, og samlet oplever $85 \%$ at dette $\varnothing$ konomiske anliggende sjældent eller meget sjældent giver anledning til problemer.

Samlet et billede af de daglige rutiner inden for spisning, døgnrytme, hygiejne, medicin og lommepenge der ikke i massiv grad opleves at give de store pædagogiske problemer i dagligdagen på bostederne. Men der er trods alt en del - omkring $30 \%$ ift. spisesituationer og hygiejneomsorg, og 16-25\% omkring soverutiner - der noterer at der ofte eller meget ofte er pædagogisk vanskelige situationer i den forbindelse.

\section{Ud af huset aktiviteter}

Et andet dagligdagsanliggende skal kort berøres. Er det medarbejdernes erfaringer, at beboerne generelt gerne vil have flere ture mv. 'ud af huset', og opleves de i almindelighed tilfredse med deres daglige arbejde/aktiviteter i de dagtilbud, de er tilknyttet enten i tilknytning til botilbuddet eller ude i byen?

To spørgsmål angår dette:

\footnotetext{
${ }^{50}$ Her erindres om, at medarbejdere, der eksempelvis aldrig har nattevagt, ikke er med i tabellen. På spørgsmålet om 'nattevandring' er således udeladt den tredjedel af det samlede antal besvarelser, hvor krydset er sat ved 'lkke aktuelt for mig/ved ikke'.
} 
Tabel 25. Synspunkter på den pædagogiske dagligdag (uddrag)

\begin{tabular}{|c|c|c|c|c|}
\hline $\begin{array}{l}\text { Synspunkter på den pædagogiske daglig- } \\
\text { dag }\end{array}$ & $\begin{array}{l}\text { Helt } \\
\text { Enig } \\
\text { Antal } \\
\text { i \% }\end{array}$ & $\begin{array}{l}\text { Del- } \\
\text { vis } \\
\text { enig } \\
\text { Antal } \\
\text { i \% }\end{array}$ & $\begin{array}{l}\text { Uenig } \\
\text { Antal i } \\
\%\end{array}$ & $\begin{array}{c}\text { Helt } \\
\text { uenig } \\
\text { Antal i } \\
\%\end{array}$ \\
\hline $\begin{array}{l}\text { Beboerne/brugerne synes, at der godt måtte } \\
\text { være flere aktiviteter ud af huset (byture, ud- } \\
\text { flugter, m.v.) }\end{array}$ & 39 & 42 & 17 & 2 \\
\hline $\begin{array}{l}\text { Beboerne/brugerne er alle eller næsten alle } \\
\text { glade for det dagtilbud, de er tilknyttet }\end{array}$ & 52 & 43 & 4 & 1 \\
\hline
\end{tabular}

Her tegnes et klart billede af, at beboerne ønsker flere ture ud af huset. Fire ud af ti medarbejdere er 'helt enige' i, at der set fra beboernes synspunkt godt måtte være flere byture, udflugter, mv., og kun $2 \%$ er 'helt uenig' heri. Samlet er det over fire femtedele ( $81 \%$ ) der er helt eller delvist enig i, at det er aktiviteter, der med fordel kan opprioriteres, hvis beboernes $\emptyset$ nsker i videst muligt omfang skal imødekommes.

Parallelt hermed er det et klart indtryk fra medarbejdernes side, at beboerne er glade for, at de er engagerede i daglige aktiviteter i de dagtilbud, de er tilknyttet. Over halvdelen er helt enige $\mathrm{i}$ at beboerne er glade herfor, og samlet er $95 \%$ helt eller delvist enige herom, mens kun $1 \%$ er helt uenig.

\section{Aggressive beboere og fysiske konflikter}

Magtanvendelse er et emne, der fylder meget såvel i professionsfaglige snakker om dagligdagen i botilbuddene, som i tilsynsrapporter, ministerielle udmeldinger og medierne.

I spørgeskemaet er ikke spurgt ind til om medarbejderne mener, der er for mange tilfælde af unødig magtanvendelse på deres arbejdsplads, idet det næppe med mening kan generaliseres på tværs af de forskellige botilbud, men der er en række spørgsmål om, hvorvidt der opleves situationer med aggressive beboere, hvor fysisk magtanvendelse kan være aktuel.

Først et centralt spørgsmål i den forbindelse, nemlig hvor sjældent eller hyppigt medarbejderne på tværs af de 22 deltagende botilbud "oplever at komme i situationer, hvor de må overveje eventuelt at bruge fysisk magtanvendelse"? 
Tabel 25. Synspunkter på den pædagogiske dagligdag (uddrag)

\begin{tabular}{|l|c|c|c|c|}
\hline $\begin{array}{l}\text { Synspunkter på den pædagogiske daglig- } \\
\text { dag }\end{array}$ & $\begin{array}{c}\text { Helt } \\
\text { enig }\end{array}$ & $\begin{array}{c}\text { Del- } \\
\text { vis } \\
\text { enig } \\
\text { Antal } \\
\text { Antal } \\
\text { i \% }\end{array}$ & $\begin{array}{c}\text { Untal i } \\
\%\end{array}$ & $\begin{array}{c}\text { Helt } \\
\text { uenig } \\
\text { Antal i } \\
\%\end{array}$ \\
\hline $\begin{array}{l}\text { Det er meget sjældent, personalet oplever at } \\
\text { komme i situationer, hvor de må overveje } \\
\text { eventuelt at bruge fysisk magtanvendelse }\end{array}$ & 48 & 31 & 14 & 7 \\
\hline
\end{tabular}

På spørgsmålet om en sådan overvejelse over at måtte gribe til fysisk magtanvendelse er svarmønstret, at det er sjældent. Samlet er fire ud af fem medarbejder helt eller delvist enig i at det er meget sjældent, der opstår en situation, hvor det kan være aktuelt, og kun 7 \% er 'helt uenig' og dermed indikerer, at det er en hyppigt opstående situation.

En relativt sjældent forekommende situation, hvor konklusionen på svarfordelingen afhænger af hvilken optik, der lægges ned over spørgsmålet, for det kan fremføres, at fysisk magtanvendelse er en så indgribende begivenhed at selv ganske få tilfælde, hvor en medarbejder overvejer at måtte gøre det, er for mange, og der er samlet en femtedel af medarbejderne (21\%) der ikke mener, at det er 'meget sjældent' forekommende.

Hvordan det så ser ud, når der spørges lidt bredere ind til konfliktsituationer og hyppighed af aggressive beboere (altså uden det direkte knyttes sammen med om det kan resultere i direkte fysisk magtanvendelse)?

Tabel 26. Pædagogisk 'vanskelige situationer' (uddrag)

\begin{tabular}{|l|c|c|c|c|}
\hline Pædagogisk 'vanskelige situationer' & $\begin{array}{c}\text { Me- } \\
\text { get } \\
\text { ofte } \\
\text { Antal } \\
\mathrm{i} \%\end{array}$ & $\begin{array}{c}\text { Ofte } \\
\text { i \% } \%\end{array}$ & $\begin{array}{c}\text { Sjæl } \\
\text { dent } \\
\text { Antal } \\
\mathrm{i} \%\end{array}$ & $\begin{array}{c}\text { Meget } \\
\text { sjældent } \\
\text { Antal i \% }\end{array}$ \\
\hline $\begin{array}{l}\text { Konflikter eller optræk til konflikter mellem } \\
\text { beboere/brugere som kræver pædagogisk ind- } \\
\text { griben }\end{array}$ & 19 & 34 & 32 & 15 \\
\hline $\begin{array}{l}\text { Beboere/ brugere som er aggressive og svære } \\
\text { at få dæmpet ned }\end{array}$ & 9 & 34 & 39 & 18 \\
\hline $\begin{array}{l}\text { Fysiske konflikter mellem en beboer/bruger og } \\
\text { personale }\end{array}$ & 5 & 17 & 42 & 36 \\
\hline $\begin{array}{l}\text { Beboere/brugere, som tiltager sig 'urimelige } \\
\text { rettigheder' i fællesarealerne }\end{array}$ & 12 & 30 & 38 & 20 \\
\hline
\end{tabular}

Indtrykket af svarmønstrene i de fire spørgsmål, der indgår i tabel 26 er, at der er en del konflikter mellem beboerne, der kræver pædagogisk indgriben, men at det er relativt sjældent at de fører til fysiske konflikter mellem beboer og pædagog eller omsorgsmedhjælper.

Hver femte medarbejder (19\%) mener at der 'meget ofte' er konfliktfyldte situationer beboerne imellem, som kræver pædagogisk indgriben, og lægges hertil dem, der 
svarer 'ofte', er det samlet over halvdelen af medarbejderne (53\%), der mener konfliktsituationer er ofte eller meget ofte forekommende mod $15 \%$, der svarer 'meget sjældent'. Andelen af medarbejdere, der ofte eller meget ofte oplever at fysiske konflikter med en beboer forekommer, er betydeligt mindre, men på ingen måde lille, idet op mod en fjerdedel ( $22 \%$ ) sætter deres kryds ved disse to svarmuligheder, mens en god tredjedel (36\%) mener, at det er meget sjældent forekommende.

Tilsvarende er der tale om relativt høje procenttal medarbejdere, der oplever at nogle beboere ofte eller meget ofte har en aggressiv adfærd eller opfører sig 'urimeligt' med hensyn til takt og tone i fællesarealerne, idet mere end to ud af fem medarbejdere (43\%) sætter kryds ved de to svarkategorier ifm. 'aggressive beboere' og en tredjedel (32 \%) på spørgsmålet om der er "beboere, som tiltager sig 'urimelige rettigheder' i fællesarealerne".

I hvor høj grad konflikter, urolige/aggressive beboere og eventuelt voldelige situationer i dagligdagen direkte opleves som psykisk belastende er her nærliggende at inddrage.

Her er svarmønstrene på tre spørgsmål i den sammenhæng følgende:

Tabel 21. Belastende psykiske faktorer i arbejdet (uddrag)

\begin{tabular}{|l|c|c|c|c|}
\hline $\begin{array}{l}\text { Belastende psykiske faktorer i } \\
\text { arbejdet }\end{array}$ & Slet ikke & $\begin{array}{c}\text { I mindre } \\
\text { grad } \\
\text { Antal i \% }\end{array}$ & $\begin{array}{c}\text { I nogen } \\
\text { grad } \\
\text { Antal i \% }\end{array}$ & $\begin{array}{c}\text { I høj } \\
\text { grad } \\
\text { Antal i \% }\end{array}$ \\
\hline $\begin{array}{l}\text { Beboerne/brugerne er uroli- } \\
\text { ge/voldsomme }\end{array}$ & 18 & 36 & 28 & 17 \\
\hline Trusler om vold & 35 & 37 & 17 & 10 \\
\hline Udsat for vold & 39 & 36 & 13 & 11 \\
\hline
\end{tabular}

En relativ stor andel medarbejdere bemærker 'slet ikke' psykiske belastninger i forhold til urolige/voldsomme beboere (18\%) eller oplevelse af trusler om vold (35\%), men i den anden ende af spektret er også en ganske stor andel medarbejdere, der 'i høj grad' oplever psykiske belastninger ift. urolige/voldsomme beboere (17\%) eller trusler om vold (10\%).

Det tredje spørgsmål er her lidt mere direkte, nemlig hvor mange der oplever at udsathed for voldelig adfærd fra beboerside opleves psykisk belastende. Fire ud af ti (39 \%) svarer 'slet ikke', som antyder, at de aldrig har været udsat herfor, mens det er omkring en fjerdedel (24\%), der i 'nogen' eller 'høj' grad oplever at 'være udsat for vold' som en psykisk belastende del af arbejdet.

Et samlet indtryk af problemstillinger i forbindelse med konflikter og eventuel voldelige episoder i dagligdagen er at de ikke er massivt dominerende, men dog på ingen måde kan negligeres. At over en femtedel af de deltagende pædagoger og omsorgsmedhjæl- 
pere er uenige eller helt uenige i, at situationer, hvor de må overveje muligheden for fysisk magtanvendelse er meget sjældent forekommende må vurderes som mange. Tilsvarende med de mere end $50 \%$ af medarbejderne, der oplever at konflikter eller optræk til konflikter beboerne imellem er ofte eller meget ofte forekommende, og endelig at lidt under halvdelen (45 \%) oplever urolige eller voldsomme beboere i 'nogen' eller 'høj' grad som en psykisk belastende del af det daglige arbejde.

\section{Samarbejde med de pårørende}

I kapitel 1 berørtes spørgsmålet om samarbejde med pårørende via resultater fra andre undersøgelser, og det fremgik, at samarbejdet $\mathrm{i}$ al almindelighed ser ud til at fungere ganske godt, dog med tendensen til, at jo nærmere indblik i dagligdagen, de pår $\varnothing$ rende har, desto højere tendens til mindre tilfredshed med de vilkår, deres pårørende lever under i botilbuddet.

I spørgeskemaundersøgelsen her er spurgt ind til samarbejdet med pårørende under tre af spørgsmålene, og når det (som her) er pædagoger og omsorgsmedhjælpere, der skal vurdere samarbejdsrelationerne, tegner der sig ikke de store problemer. Som det fremgår af tabel uddraget nedenfor markerer $90 \%$ af alle adspurgte medarbejdere, at de oplever at de "pårørende til beboere/brugere påskønner alle eller næsten alle den indsats, vi yder i dagligdagen", og kun $2 \%$ er helt uenige heri.

Tabel 25. Synspunkter på den pædagogiske dagligdag (uddrag)

\begin{tabular}{|l|c|c|c|c|}
\hline $\begin{array}{l}\text { Synspunkter på den pædagogiske daglig- } \\
\text { dag }\end{array}$ & $\begin{array}{c}\text { Helt } \\
\text { enig }\end{array}$ & $\begin{array}{c}\text { Delvis } \\
\text { enig } \\
\text { Antal i i } \\
\%\end{array}$ & $\begin{array}{c}\text { Uenig } \\
\%\end{array}$ & $\begin{array}{c}\text { Helt } \\
\text { uenig }\end{array}$ \\
$\begin{array}{l}\text { Antal i } \\
\%\end{array}$ & $\begin{array}{c}\text { Antal i } \\
\%\end{array}$ \\
\hline $\begin{array}{l}\text { eller nærende til beboere/ brugere påskønner alle } \\
\text { dagen }\end{array}$ & 40 & 50 & 7 & 2 \\
\hline
\end{tabular}

Et er om de pårørende opleves som rimeligt tilfredse med bostedet, noget andet om de kan være 'vanskelige' at samarbejde med eller skulle tage tilpasse hensyn til. Her er svarmønstrene knapt så entydige:

Tabel 26. Pædagogisk 'vanskelige situationer' (uddrag)

\begin{tabular}{|l|c|c|c|c|}
\hline Pædagogisk 'vanskelige situationer' & $\begin{array}{c}\text { Meget } \\
\text { ofte }\end{array}$ & $\begin{array}{c}\text { Ofte } \\
\text { Antal i } \\
\%\end{array}$ & $\begin{array}{c}\text { Sjæl- } \\
\text { dent } \\
\%\end{array}$ & $\begin{array}{c}\text { Meget } \\
\text { sjæl- } \\
\text { dent } \\
\text { Antal i } \\
\%\end{array}$ \\
$\begin{array}{l}\text { Antal i } \\
\%\end{array}$ \\
\hline $\begin{array}{l}\text { Pårørende som udtrykker forventninger/krav, } \\
\text { der ikke kan indfries }\end{array}$ & 4 & 19 & 47 & 30 \\
\hline
\end{tabular}

Næsten en fjerdedel af medarbejderne (23 \%) oplever 'ofte' eller 'meget ofte' at pårørende har forventninger eller udtrykker krav, som af den ene eller anden grund ikke 
kan indfries, men det er dog en mindre gruppe end den, der mener at dettte 'meget sjældent' sker (30\%), og lægges hertil dem, der svarer 'sjældent', er det næsten fire ud af fem medarbejdere (77 \%), der 'sjældent' eller 'meget sjældent' oplever pædagogisk vanskelige situationer i samarbejdet med de pårørende.

På den baggrund er det forventeligt, at samarbejdet med pårørende ikke i nævneværdig grad udgør en psykisk belastning i arbejdet, men her er svarmønstret - når der spørges ind til om pårørende opleves at 'kræve' for meget - knap så klart:

Tabel 21. Belastende psykiske faktorer i arbejdet (uddrag)

\begin{tabular}{|l|c|c|c|c|}
\hline $\begin{array}{l}\text { Belastende psykiske faktorer i } \\
\text { arbejdet }\end{array}$ & Slet ikke & $\begin{array}{c}\text { I mindre } \\
\text { grad } \\
\text { Antal i \% }\end{array}$ & $\begin{array}{c}\text { I nogen } \\
\text { grad } \\
\text { Antal i \% }\end{array}$ & $\begin{array}{c}\text { I høj } \\
\text { grad } \\
\text { Antal i \% }\end{array}$ \\
\hline Pårørende kræver for meget & 41 & 34 & 16 & 8 \\
\hline
\end{tabular}

Der er en stor andel (41\%), der 'slet ikke' finder, at "pårørende kræver for meget", men i den anden ende af spektret er der trods alt en fjerdedel (24 \%) der i 'nogen' eller 'høj' grad sætter deres kryds ved, at de pårørende opleves krævende.

\section{Samarbejde og kontinuitet i det pædagogiske arbejde}

En sidste facet omkring synspunkter på det daglige arbejde i botilbud skal med i denne omgang, nemlig hvordan pædagoger og omsorgsmedhjælpere oplever samarbejdet mellem døgn- og dagtilbuddene, og i hvilken grad, der opleves kontinuitet i dagligdagen, hvad angår personalebemandingen.

Hvad angår samarbejde med dagtilbuddene ser der generelt ikke ud til at være de store problemer. Kun 8 \% er 'uenig' eller 'helt uenig' i at "samarbejde og praktisk koordinering mellem bostedet og dagtilbuddene fungerer i det daglige godt", mens halvdelen (54 \%) er delvist enige og 38 \% erklærer sig helt enige heri, jf. første spørgsmål i uddraget fra tabel 25:

Tabel 25. Synspunkter på den pædagogiske dagligdag (uddrag)

\begin{tabular}{|l|c|c|c|c|}
\hline $\begin{array}{l}\text { Synspunkter på den pædagogiske daglig- } \\
\text { dag }\end{array}$ & $\begin{array}{c}\text { Helt } \\
\text { enig } \\
\text { Antal i } \\
\%\end{array}$ & $\begin{array}{c}\text { Delvis } \\
\text { enig } \\
\text { Antal i } \\
\%\end{array}$ & $\begin{array}{c}\text { Uenig } \\
\text { Antal i } \\
\%\end{array}$ & $\begin{array}{c}\text { Helt } \\
\text { uenig } \\
\text { Antal i } \\
\%\end{array}$ \\
\hline $\begin{array}{l}\text { Samarbejde og praktisk koordinering mellem } \\
\text { bostedet og dagtilbuddene fungerer i det dag- } \\
\text { lige godt }\end{array}$ & 38 & 54 & 7 & 1 \\
\hline $\begin{array}{l}\text { I almindelighed er der en god balance mellem } \\
\text { fast gennemgående personale og tilkaldevika- } \\
\text { rer }\end{array}$ & 47 & 39 & 10 & 3 \\
\hline $\begin{array}{l}\text { Der er for ofte perioder, hvor sygdom, ubesat- } \\
\text { te stillinger o.a. medfører et for stort gennem- } \\
\text { træk af vikarer på bostedet/afdelingen i dag- } \\
\text { ligdagen }\end{array}$ & 28 & 32 & 24 & 16 \\
\hline
\end{tabular}


Endnu større tilfredshed er der som helhed på spørgsmålet om balancen mellem fast personale og tilkaldevikarer. Her er næsten halvdelen (47\%) 'helt enige' i, at der er en god balance mod $13 \%$ er 'uenig' eller 'helt uenige', og $39 \%$ 'delvist enige'.

Et knapt så positivt indtryk er der, når det drejer sig om den daglige medarbejderkontinuitet. Blandt medarbejdere i botilbud høres ofte snakker om et uafladeligt gennemtræk af mere eller mindre løse vikarer pga. personalemangel, sygdom mv., og nok bekræftes dette billede i et af spørgsmålene i spørgeskemaet, men i knap så massiv grad, som umiddelbart kunne forventes ud fra de indtryk, der dannede sig, da de forberedende interviewsamtaler og materialestudier gennemførtes forud for udarbejdelsen af spørgeskemaet.

Et flertal svarer bekræftende på at "der er for ofte perioder, hvor sygdom, ubesatte stillinger o.a. medfører et for stort gennemtræk af vikarer på bostedet/afdelingen $i$ dagligdagen" (60\% er helt eller delvist enige heri), men der er trods alt ikke flere end en god fjerdedel ( $28 \%$ ) der mener sig 'helt enig' heri, mens - i den anden ende af spektret - $16 \%$ er 'helt uenig', og samlet fire ud af ti medarbejdere er således mere eller mindre uenig i, at der for ofte er for stort gennemtræk af vikarer på det bosted, de arbejder.

'Det gode liv i egen bolig, etiske dilemmaer og vanskelige beboere. Myte eller fakta?' var overskriften på kapitel 3, og mange facetter uden entydige konklusioner har været inddraget undervejs. På flere områder peges der af medarbejderne på problematiske sider i det daglige arbejde med beboerne, men samtidig efterlader de mange svarmønstre også et indtryk af en generel positiv stemning omkring det daglige arbejde fra hovedparten af de deltagende pædagoger og omsorgsmedhjælpere.

Hvilket billede tegner der sig så, når en 'fremmed kommer på besøg' og har som opgave at nedskrive sine indtryk af dagliglivet på et botilbud med tilknyttet dagtilbud? Det er temaet i kapitel 4. 


\title{
Kapitel 4
}

\section{Kontaktsomhed - en antropologisk feltberet- ning fra et bo- og dagtilbud}

\author{
Onsdag formiddag.
}

Det er første feltarbejdsdag og rundvisningen er lige afsluttet i Dagtilbuddet. Jeg kigger mig nysgerrigt omkring i gangen. Der er store vinduer og hvide vægge med rækker af magnetiske 'klokkestrenge' af små udskiftelige laminerede billeder: kaffe, guitar, pause, arbejdsbord, vaske hænder, spise frokost og så videre. Én streng under hvert navn med en ny rækkefølge af ikoner for aktiviteter. Jeg følger gangen rundt om hjørnet, forbi en masse døre, ind i kantinen. Der er tre lange rå træborde med stole omkring og en vogn med service, frugtskåle på køkkenbordet og et køleskab. Ved siden af et par malerier hænger der en række æsker med gummihandsker i alle størrelser.

Jeg hilser på en af pædagogerne ${ }^{51}$, som spørger, om jeg ved meget om autisme; men så kommer Bodil ${ }^{52}$ ind. Hun går direkte og målrettet over til mig. To pædagoger følger med. Der er $10 \mathrm{~cm}$ mellem vores næser, Bodils og min. Hun kigger mig direkte i $\varnothing j n e n e$ og spørger, hvad jeg hedder. Det fortæller jeg. Hun siger "Annemarie. Vi kender ikke hinanden". Nej det gør vi ikke. Hun taler hurtigt og hektisk. Jeg tror, hun er endnu tættere på nu. En af pædagogerne siger "Bodil - hvem er du med? Du er med Marit!". Bodil stirrer stadig fast på mig "Bodil du er med Marit" gentager pædagogen. Bodil vil snakke mere, så hun siger igen, at vi ikke kender hinanden. Pædagogen Marit siger "Bodil Kom. Du Er Med Marit". Det interesserer ikke Bodil. Hun hører det vist slet ikke. Hendes udelte opmærksomhed er hos mig. Jeg drejer mig lidt væk. Kigger i stedet på Marit. Endnu en pædagog kommer til. Hun siger til sin kollega, at hun vil prøve fra den anden side: "Bodil. Du er med Marit. Kom". Nu vender Bodil sig om mod Marit og går med raske skridt med hende ind i det tilstødende rum. Bodil skal til at holde pause.

Mit første møde med de mennesker der lever deres arbejds- og hverdagsliv i min felt drejede sig om kontakt ${ }^{53}$. Kontakt blev et gennemgående tema i min daglige gang $i$

\footnotetext{
${ }^{51}$ I feltberetningen omtaler jeg de ansatte som medarbejderne eller pædagoger. Der er flere forskellige faggrupper repræsenteret i Bo- og Dagtilbud, men jeg skelner ikke mellem disse i mine benævnelser, for mit generelle indtryk er, at der ikke i praksis skelnes mellem pædagogisk uddannede og medarbejdere med andre uddannelser i det daglige arbejde med brugerne/beboerne og i konstruktion af arbejdsplaner.

${ }^{52}$ Af hensyn til tavshedspligt og den enkeltes privatliv er alle brugere, beboere og medarbejdere anonymiseret med opfundne navne. Medarbejderne med navne der begynder med $\mathrm{M}$ og beboere/brugere med navne der begynder med $B$.

${ }^{53}$ Fra Politikens Nudansk Ordbog: Opslag: Kontakt = det at være i en tilstand el. en situation, hvor man er i stand til at udveksle information, holdninger, følelser el.lign. med andre = Berøring, Forbindelse ... det at forskellige ting berører hinanden ... bekendtskab med en person ... også om selve personen.
} 
felten. Men kontakt har forskellige udtryk, former og mange formål. Og kontakt kan være initieret, besvaret, hørt, set, omtolket eller ignoreret af forskellige mennesker i felten. Som mit første møde med felten viser, vil Bodil gerne i kontakt med mig. Hun kontakter mig på sin direkte facon med et fast blik og opklarende spørgsmål, og hun opnår så sandelig min opmærksomhed. For jeg er første dag, på det yderst tidlige tidspunkt af mit feltarbejde, uvidende om, at Bodils kontakt er uønsket af medarbejderne med deres pædagogiske strategier, og jeg snakker med hende, netop fordi hun har kontaktet mig så tydeligt ved at gå helt hen til mig og undersøge, hvem jeg er.

Medarbejderne kontakter derimod Bodil, som slet ikke har øje for dem og det de vil med hende. Hun har kun øje for den nye Annemarie med skriveblokken, som hun ved, hun ikke kender endnu. De må være tre mand høj om at få kontakt med hende, før det lykkes en af dem at aflede hendes opmærksomhed fra mig og få hende til at følge med Marit ind og holde pause. Her i Dagtilbud kan pause ikke forstås som at tale med mig. Det har jeg allerede lært.

Jeg er i felten i to uger. Min tid fordeler jeg tilnærmelsesvis ligeligt mellem Dagtilbuddet, og Botilbuddene 5. sal og 7. sal. Morgen, middag, aften og alle tider der imellem. Min viden får jeg gennem roller i felten (Wadel 1991), som er relationer mellem os (Hastrup 2003), der opstår og bliver tilgængelige gennem aflæsning og afprøvning af muligheder i konkrete sociale sammenhænge - For eksempel en maleaktivitet med Bitten og Beate på 5. sal, en lyd og en hånd fra Birger der viser mig 'følg med vi to skal lave te', eller mens vi sidder og spiser. Eller ved pludselig kontakt på 7. sal: et spontant knus fra den autistiske kvinde Bea, arm i arm med lydløse Benny på en gåtur ved havnen, trukket af sted af Bo ind i lejligheden for at læse i hans piktogrammappe for 'syttende gang' den eftermiddag. Ved brud på konventionerne i Dagtilbud: en lidt for lang og snaksom stund med Betty, som efter planen skal arbejde selvstændigt ved sit arbejdsbord. Roller bliver også tilgængelige ved, at jeg får en udpeget af medarbejderne: Det kan være en anvisning på, hvordan jeg skal forholde mig klogt i en særlig sammenhæng sammen med særlige mennesker. Og som i indledningen ovenfor bliver jeg konstant min egen informant (Wadel 1991) i mange af de roller, jeg efterhånden har i felten.

Fordi alt i min felt har med kontakt at gøre, og kontakt er så mangesidig en handlingsform af individuel og fælles karakter, har jeg benævnt det tema, som min feltberetning er centreret omkring kontaktsomhed. Det er én historie om måder, man er sammen på og dermed om socialpædagogik. Efterhånden som jeg i min vekselvirkning mellem teori, metode og data (Wadel 1991), har fået indblik i og fornemmelse, baseret på timers samvær, af hverdagsliv i bo- og dagtilbud, har jeg som feltforskningsstrategi forfulgt kontaktsomhed opmærksomt (Marcus 1998). Ved direkte deltagelse og ved tilstræbt tilbagetrukket observation. Senere, i min analyse hjemme ved skrivebordet, 
har jeg undersøgt mønstre i kontaktsomhed i det daglige liv og den daglige pædagogiske praksis som beboere, brugere og medarbejdere åbnede for mig. Tak for jeres åbenhed på hver jeres måde, skal I alle sammen have.

Kontaktsomhed udtrykker hverdagsliv i bo- og dagtilbud. Både når det er med højt humør og lystbetonet, når det er stille, afslappet eller dovent, og når nogen er ked af det eller meget vred. Kontaktsomhed er både en henvendelse, og det er en respons på en henvendelse. Det er både hverdagsliv og pædagogik, det er socialt og det er helt alene i verden.

\footnotetext{
$\rightarrow$ Beboerne på 7. sal er færdige med at spise morgenmad. De samles i de lysebrune lænestole omkring sofabordet. Et par stykker har taget jakker på. En af pædagogerne er ved at pakke tasker med madkasser og dagbøger med overleverende informationer.

Bo rejser sig op og stiller sig foran Bea. Han strækker hånden frem mod hende og så peger han ud ad vinduet. Han siger en spørgende mmm-lyd. Jeg er spændt: Skal de snakke sammen? Bea vender sig væk og trækker begge ben op under sig i stolen. Bo kigger sig omkring. Vi er tre ansatte og en antropolog, der har overværet Bo og Beas kontakt. Han vender sig mod Mikkel og lægger begge hænder på hans skuldre. Øjenkontakt. Det er de to. Så begynder han at lave tegn igen - Antropologen kan identificere tegn for 'kaffe', 'spise' og 'ude' mellem hinanden. Mikkel siger: "Hent din mappe Bo, jeg forstår ikke alle de tegn". Bo går med raske skridt ud af stuen. Han siger høje brummende Åmåmåmlyde, mens han går. $\leftarrow$
}

\section{"Ja, for jeg skal jo ikke mangle noget" siger Beate}

På 5. sal bor syv voksne udviklingshæmmede/fysisk handicappede mennesker. Det er et bofællesskab 'på godt og ondt'. Her lever beboerne deres liv før og efter arbejde, i fritid og weekender, $i$ et hjem der både er den enkeltes eget og delt med de $\varnothing v$ rige beboere - Nogle holder man af, andre er det sværere at være i stue med - og så er der et antal ansatte. Det er de faste, kontaktpersonerne og alle vikarerne. For en periode også antropologen.

Beboerne har hver sin etværelses lejlighed med bad. Ordet værelse er bandlyst. De bor på en sal (ikke en afdeling), og de har fællesfaciliteter i form af stue, altan til at slikke solskin, køkken og spisestue. Men man kan godt spise i lejligheden. Hvis de vil være sig selv, er det til lejligheden, beboerne søger hen. Det oplever feltarbejderen ofte om aftenen. Som Britta efter en snak siger, "Nu har jeg ikke mere at sige, vil du køre mig i lejligheden?”. En af pædagogerne kommer til hjælp. Antropologen har ikke 'kørekort' til den elektriske kørestol. Straks efter er Brian i gang med at organisere aftenkaffe til alle fra bakken på spisebordet. Han kører ind til Britta med hendes personlige plastkrus med te og den rette mængde mælk til, at hun kan drikke den med sugerør. Lidt efter er han tilbage. Han vil også hælde kaffe op til Beate, som ryger på gangen. Birthe pakker chokolade ud. Hun synes, der skal hygges ekstra om kaffen i aften. 
Kontaktsomhed mellem beboerne på 5. sal er en central del af dagligdagen, det finder jeg hurtigt ud af. Somme tider er den ukompliceret og understøttende af det fordragelige liv sammen og side om side, ligesom ved aftenkaffen jeg har beskrevet ovenfor og i situationen her:

$\rightarrow$ Birthe er lige stået op. Birger sidder i lænestolen og bladrer i et ugeblad. Det vender på hovedet. Den ellers fåmælte Birthe, som plejer at svare med lyde, siger "Godmorgen Birger". Men den næsten $\mathrm{d} \emptyset$ ve Birger hører ikke noget. Birthe siger ja til at blive kørt helt over til ham af Marianne, som har hørt hendes morgenhilsen. Så får Birger øje på Birthe, og de to giver hinanden et lille kindkys, før de et splitsekund efter igen er hver for sig - i gang med henholdsvis blad og at beslutte sig for morgenmad. $\leftarrow$

En fordragelig 'hverdagstone' karakteriserer kontakten mellem beboerne på 5 . sal. Andre gange er samværet mellem beboerne helt anderledes spændt:

\footnotetext{
$\rightarrow$ Beate har hjemmedag. Hun skal til tandlægen senere, og har haft en morgen præget af bekymring og tristhed. Brian venter på sin bus som er forsinket. Han har ventet i over en time med jakke på og tasken pakket. Han glæder sig til at komme af sted og er blevet utålmodig og pirrelig over for indblanding i situationen. Nu skal den bus bare komme, det er tydeligt at se på Brian: Han tager igen og igen opstilling foran elevatoren. Han hænger med hovedet - Han ligger faktisk hen af kørestolsbordet foran sig. Han siger irriteret " $\varnothing v-\varnothing v-\varnothing v "$.

Beate får måske tankerne om tandlægen lidt på afstand ved sin optagethed af Brians situation: "Skal vi ringe efter bussen, Brian, skal vi det?"

Brian siger stille hen for sig, at han har glædet sig sådan til at komme af sted.

Beate: Han [chaufføren $\mathrm{AH}$ ] kan ikke gøre for, at han er sent på den.

Brian: LAD nu VAERE for helvede!

Beate: Det kan han ikke gøre for, at han er.

Marianne: Lad være med at blande dig i det, Beate

Beate skuler ud til Brian på gangen, men siger ikke mere om det nu. $\leftarrow$
}

Som feltuddragene viser, er kontaktsomhed på 5. sal nogen at være sammen med, og det er nogens liv at forholde sig til. Det er tydeligt, at beboerne følger nøje med i hinandens liv, og de glæder sig over gode nyheder, ligesom de også underst $\varnothing$ tter og forstærker stemninger hos hinanden.

For eksempel er de andre meget opmærksomme på Beate, der skal til tandlægen, og flere af dem viser pædagogerne, at de godt er klar over det. Enten med tegn, lyde eller ord. Det giver anledning til at medarbejderne bekræfter situationen, hvormed de ligeledes viser, at de er klar over og anerkender emnets væsentlighed. Det sker for eksempel også ved mindet om en faldsituation på badeværelset for flere måneder siden, som aktualiseres via overhøring af en samtale om en ny sele i et løfteredskab inde hos en helt anden beboer. 
Måske bruger medarbejderne situationen pædagogisk ved at udtrykker en generel holdning, der kan berolige: Bitten har peget på sin kæbe og på Beate, som uden for vinduerne tager af sted med Manja til tandlægen, og sagt "Nej, nej, nej". Michael bekræfter Bittens aflæsning af situationen og svarer "Nej, Beate gider ikke rigtig til tandlægen, hun er lidt ked af det, men det er jo kun en tandlæge". Og han tilføjer en almindelig nedtoning af bekymringen: "Det er jo noget alle skal, have tjekket sine tænder en gang imellem, og I har jo prøvet det før. Har du ikke prøvet det Bitten?". Det bekræfter Bitten med en 'ja-lyd'. "Mange gange, ik'os'?" konkluderer Michael.

Men det er også delte glæder på hinandens vegne, der præger det kontaktsomme liv: Birgitte der henter sin guitar og kvitterer med at 'give et nummer', efter at den ellers helt stille Birger strålende siger "Hurra Hurra" over oplæsningen af et feriepostkort fra sin familie. Eller da dagen endelig oprinder, hvor Birthe skal have sin ny elkørestol, er det næsten alle, der giver udtryk for det om morgenen og kommenterer, at det er i dag. Gentagne gange bliver det bekræftet af medarbejderne. Næste dag bliver stolen omtalt i flatterende vendinger vedrørende dens gode fodst $\varnothing$ tter og den slags 'insiderkendskab’ om sådan et køretøjs fortræffeligheder. Alle glæder sig på Birthes vegne og følger udviklingen med at få stolen 'i hus'.

Som fremstillet ovenfor er medarbejderne en stor og uomgængelig del af hverdagen på 5. sal, hvor 5 ud af 7 beboere er kørestolsbrugere og alle har brug for hjælp og støtte til helt basale dagligdags gøremål så som at komme op af sengen, at blive barberet, vasket, få mad og så videre. Men ikke mindst i forhold til en kvalificeret daglig kontakt der imødekommer den enkeltes behov for samhørighed med og forståelse fra andre mennesker.

Antropologen oplever situationer, hvor en sådan kontakt med medarbejderne er præget af taknemmelighed og meget stor tålmodighed over for samværets karakter og muligheder. Beboerne accepterer, at der også skal laves organisatoriske ting i medarbejdernes arbejdstid, ligesom andre beboere pludselig kan kræve pædagogens opmærksomhed, hvorfor kontakten 'definitivt' eller for en stund må ophøre. Lidt efter sker der noget andet. Nyt samvær, ny kontakt. Sådan er det kontaktsomme liv på 5 . sal.

Det er for eksempel når Bitten kommer til stuen og kører hen til bordet. Hun har ikke et decideret talesprog, men anvender be- og afkræftende lyde og venter som oftest roligt på, at nogen har tid til at være sammen med hende. Bitten kan lide at kigge i sit dameblad, og det ved medarbejderne. Da hun ikke selv bladrer, har hun brug for at nogen sætter sig og læser med hende. Når de afbrydes, venter hun stille - måske læser de videre senere, måske sker der ikke mere, eller måske kommer der en anden og læser med hende: "Den der taske Bitten, kan du lide den?" "Ja", "Det er også lige din rosa 
farve". Det kan være de joker ved at Bitten peger på en sjov frisure i bladet og så på Michaels hår, og han siger "Det kunne du tænke dig hva' Bitten, at jeg skulle se sådan ud? - Du kan lige tro nej". Bitten ler stort, nu har de rigtig snakket sammen. Eller Birgitte der vil have tændt for TV, men må vente til Britta er blevet kørt ind i lejligheden: "Hvor er du tålmodig" siger Martin, da han kommer tilbage. "Ja" svarer Birgitte og sætter sig til rette og siger veltilfreds "Aj ja-ja ja-ja", da det er Snurre Snup der vises.

Selvom det overordnede indtryk er, at det næsten har 'egenskabskarakter' hos beboerne at ventet tålmodigt og taknemmeligt på samvær og nær menneskelig kontakt, kan der også siges at være antydning af en 'træning i at udsætte behov' i det daglige samspil mellem medarbejdere og beboere. Til tider anes altså en pædagogik om, at forholde sig tålmodigt og afventende og udskyde ønsker og behov:

\footnotetext{
$\rightarrow$ Britta har vist både pædagog og antropolog et fødselsdagskort, hun skal sende til sin besøgsven. Vi beundrer kortet, mens Britta får tøj på, og pædagogen bekræfter, at de har været ude at købe det på Brittas hjemmedag. De fortæller, at de skal skrive det senere i dag. Britta glæder sig tydeligt til den gode aktivitet: Hun siger "Ja" og smiler meget. Hun søger øjenkontakt og spørger, om jeg har forstået. Det har jeg. Inde i stuen vil Britta tale mere om kortet. Igen bekræftes aftalen. Nogle timer senere spørger Britta pædagogen, om de skal skrive kortet. Pædagogen siger, "Du behøver ikke at spørge hele tiden, jeg har sagt til dig, at vi nok skal gøre det". Britta bliver stille og beder lidt efter om at blive $k \varnothing r t$ ind i lejligheden. $\leftarrow$
}

Over for en taknemmelig og afventende 'grundholdning' og en glimtvis antydning i praksis af en træning $\mathrm{i}$ at udskyde behov for kontakt, er der også en mentalitet, der handler om at 'forbruge' de ansatte som et personale i eget hjem, der gør sig gældende på 5. sal.

Det er den form for kontaktsomhed, der har givet afsnittet om kontaktsomhed på 5. sal sin titel. For antropologen fornemmer, at det mønster grundlæggende er pædagogisk initieret af en helt basal opfattelse af dels, at det er beboerens hjem, det pædagogiske arbejde foregår $\mathrm{i}, \mathrm{og}$ dels at den $\mathrm{n} \varnothing \mathrm{dvendige}$ tid med den enkelte, så snart pædagogen er på egen hånd med beboeren, prioriteres. Og at det mønster - underliggende eller tydeligt - i vid udstrækning er til stede i mange typer af kontaktsomt samvær. Det foregår i form af en respektfuld tilstedeværelse i beboerens liv og hjem hos dem, som ikke benytter talesprog, mens de som taler, som det fremgår herunder, selv fremmer sådan en kontaktsomhedsform.

\footnotetext{
$\rightarrow$ Beate og jeg er de eneste i stuen. Beate vil gerne ud at ryge. Hun kører fra bord til bord og kigger sig om. Hun ser på mig og siger "Hvor er ekstra-lighteren?". Jeg ved faktisk ikke, hvor nogen ting er ud over de selvindlysende, så jeg siger, at det er jeg ikke klar over, men at Manja bare er nede på kontoret, så vi kan nemt spørge hende, når hun kommer igen om lidt. Beate svarer ikke først, men kører ud af stuen. I døråbningen standser hun op, vender sig om, kigger på mig og siger, "Ja, for jeg skal jo ikke mangle noget". $\leftarrow$
} 
Generelt kan man sige, at Beate tematiserer et mønster i kontaktsomhed på 5. sal, som sammen med de andre kontaktformer jeg har præsenteret ovenfor, er meget typisk. Det er en type situationer jeg, som min egen informant, ofte oplever mig impliceret i i den hverdag, jeg så vidt muligt forsøger at komme tæt ind i. Men det er et meget vidtspændende mønster - det er alt fra ikke at skulle mangle en lighter og derfor muligheden for at nyde sin eftermiddagscigaret, til at være sikker på at få lagt vasketøj sammen eller strøget skjorten til en planlagt tur i byen, eller til at få den nødvendige hjælp med at få skåret sin mad ud og få salt og peber på:

\footnotetext{
$\rightarrow$ Brian har hjemmedag. Han har sovet længe og har valgt et langt, langt bad. Nu inviterer han antropologen til at spise frokost sammen med sig. Merete siger, "Jamen så må jeg jo ned og lave en hel masse spejlæg". Brian og jeg sidder side om side. Merete og Birger på den anden side. Brian vil have skåret sin mad ud. Merete rejser sig. Men Brian siger, "Annemarie gør det". Så det gør jeg. Han griner af, at det tager mig lidt tid. Jeg er ikke vant til at udskære flotte bidder til andre. Men han siger "Annemarie, hun er god nok", og han beder mig hente salt og peber på emhættehylden i køkkenet. $\leftarrow$
}

Det er situationer med mulighed for nær kontaktsomhed om praktiske gøremål. Men sagtens af mere pædagogisk karakter om aktivitet, deltagelse og selvhjulpenhed: "Nu har jeg fyldt din vaskemaskine, så kan du bare tænde på knappen, når du er færdig med badet", lyder det eksempelvis.

Mønstret eller typen af situationer rummer også, at beboerne ikke skal mangle omsorg, når de er kede af det, vrede, eller bange for noget. "Prøv at mærke jeg holder fast på dig" siger Merete, da Britta er bekymret for at glide på gulvet ved afklædningstid. Og som sådan kan kontaktsomheden være en tryghedsstrategi, som medarbejderne imødekommer især i tosomhedssammenhænge:

$\rightarrow$ Beate er trist. Hun skal til tandlægen senere. Hun og jeg sidder i gangen, da Michael kommer forbi. Hun kigger op på ham og siger, "Det er noget rigtig møg, jeg skal til tandlæge i dag". Hun er ked af det, græder lidt. Han siger, at det er godt at få efterset bisserne og at hun jo har gode tænder. Han holder hende i hånden. De har god tid. Snakker længe om det. Han prøver at forstå, hvad hun er bekymret for: tanken om det eller selve situationen. Endelig får hun stille udtrykt at "Jeg synes, det er pinligt". Michael siger, at det er det helt bestemt ikke, for alle også han selv går til eftersyn engang imellem. Hun liver op, tænker lidt. De er helt stille sammen, og der kommer et lille smil. De holder i hånden lidt endnu. Da hun ikke er så ked af det mere, foreslår Michael, at de bruger ventetiden til noget rart. Han spørger, om Beate vil være med til at male. De siger indforstået "Deal" til hinanden og hun ler opmuntret. $\leftarrow$

Kontaktsomhed på 5. sal er nøje at følge hinandens liv, og det er medarbejdernes kendskab til den enkelte beboer. Det er at fremme livet, så det bliver sammen, og foregribe $f \varnothing r$ kontakt bliver ubekvemt for nogen. Det er, at de er sammen om at kende 
og huske højdepunkterne i hverdagen: Den gode madpakke, ønskekoncerten i radioen søndag, damebladet torsdag, bestemme-mad-dagen i weekenden, beboermødet om et par uger, find fem fejl og en god stabil besøgsven ... og de fælles oplevelser foreviget på væggene i form af fotos af alle, der spiser is eller har solbriller på ved stranden. Medarbejderne er et 'link' til livet uden for Botilbud - det er Michael, der forsikrer, at det er almindeligt at gå til tandeftersyn, det er cafébesøget hvor bardamen aer på kinden, anden dag de dukker op, oplæsningen af et postkort om familiens ferietur, og det er historier om medarbejdernes hverdagsliv: Meretes frække kat, Michaels sofa, Martins flytning, Margretes studie ... Nysgerrigt spørges og lyttes der og tænkes efterfølgende.

\section{Med metode som omdrejningspunkt}

Deltagerobservation i Dagtilbud er både ukompliceret og vanskeligt. Det er ukompliceret og ligetil at falde ind i fra dag til dag, fordi hverdagen i stor udstrækning er karakteriseret ved den samme ret forudsigelige karakter $\mathrm{i}$ form af struktur og metoder, der gentager sig og gentager sig og gentager sig. Det er vanskeligt, fordi den deltagerobserverende tilstedeværelse i sig selv er et brud på forudsigeligheden og strukturen. Jeg måtte derfor finde måder at være der på, som kunne give mig den fornødne viden netop tilegnet på en deltagerobserverende måde, samtidig med at jeg ikke ville skabe kaos og uorden ved min deltagende tilstedeværelse.

Jeg tillærte mig hurtigt den vane at være 'høflig på en dagtilbudsmåde'. Det vil sige ikke kigge direkte og ikke hilse på brugerne, så jeg ikke kom til at distrahere og bryde med de omgangsformer og arbejdsformer, der gælder i Dagtilbud. Og det blev en væsentlig iagttagelse for mig, at jeg ligesom medarbejderne hurtigt begyndte at forholde mig sådan. Efter kun nogle få timer, havde jeg lært en 'hel masse' om kontaktsomhed og de pædagogiske metoder, og jeg begyndte i en vis udstrækning at kopiere dem i min omgang med brugerne - Forstærket af instruktioner fra medarbejderne om hvordan jeg skulle forholde mig klogt i forhold til forskellige brugere, var det næsten umuligt ikke at reproducere medarbejdernes praksis i en vis udstrækning.

For at forstå hvad jeg var i gang med og for at arbejde med min deltagerobservation, brød jeg også ind imellem forsigtigt med det, jeg godt vidste, var det tilrådede:

\footnotetext{
$\rightarrow$ Betty laver perleplader. Ved de andre borde sidder Bea og sorterer nogle småting og Bjarne med sin kugleramme. Bag afskærmningen Britt med sortering af glasbrikker. Betty vender sig om, da jeg kigger ind ad døren: "Bor du?", spørger hun. "Jeg bor i Århus". "Århus" gentager hun. Ja, siger jeg og trækker en stol over til hendes arbejdsbord. Hun skubber en perleplade over til mig. Jeg tager imod invitationen, og mens vi sætter perler på plader, får vi en lille snak. Efter et stykke tid bliver der stille. Men så siger Britt "Hjemmedag" inde bag sin skærm. Det får Bea til at grine, mens Betty også siger hjemmedag. Så begynder de at sige lyde, Betty og Britt, på skift. Frem og tilbage snakker de sådan sammen. Sådan går det lidt. Vi bytter perler imens Betty og jeg. Hun vil gerne have de røde og hun
} 
giver mig de grønne. Så kommer Marit ind. Der bliver helt stille. Marit spørger om Betty er færdig. "Nej". Hun laver videre - så det gør jeg også. Men så får jeg at vide, at jeg skal flytte mig væk fra bordet ud af syne. "Betty du skal ud og se på dit skema nu", siger Marit. $\leftarrow$

Analysen af feltmaterialet gør det muligt analytisk at udskille to styrende principper vedrørende kontaktsomhed, som ser ud til at gøre sig gældende i dagtilbud. Det ene drejer sig om, at medarbejderne i dagtilbud kan siges at have en stærkt virkende forståelse af, at brugerne (voksne med autisme / udviklingshæmning), har behov for vedvarende struktur og forudsigelighed for at fungere. Derfor bør brugerens opmærksomhed være rettet mod arbejdsopgaverne. Forståelsen af brugernes særlige behov er altså med til at styre hvilke former for kontaktsomhed, der værdisættes og søges fremmet i Dagtilbud. Det andet princip, der regulerer kontaktsomheden, drejer sig om, at medarbejderne baserer deres praksis på en høj metodebevidsthed, som de er fælles om at opretholde via deres måde at være sammen med brugerne og strukturere brugernes dag. Kontaktsomheden er altså også styret af de forskrifter for kontaktsomhed, som metoden underst $\varnothing$ tter og giver mulighed for. I praksis er der ikke tale om en adskillelse i de to principper. Det er således udtryk for en formidlingsmæssig analytisk skelnen.

En af de måder det første princip bliver tydeligt på, ja konkret eksemplificeret for feltarbejderen, er i mit første møde med felten, som jeg beskrev i indledningen. Mønstret er også tydeligt i følgende situation, hvor jeg ved min blotte tilstedeværelse giver anledning til ikke planlagt kontaktsomhed. Det bryder princippet om koncentreret at være uafledelig fra arbejdsopgaven, som underst $\varnothing$ tter strukturen:

\footnotetext{
$\rightarrow$ Jeg går ind i værkstedet. Bahood, som sidder med et puslespil, vender sig om. Han fornemmer nok, at der foregår noget bag ham. Han ser mig som så mange gange før, men i dag rejser han sig op og laver kyssemund og smask-lyd. Straks får han et fortrydende udtryk i ansigtet. Han vender sig straks om mod væggen igen og tager et stykke papir frem. Magda kommer hen til ham. De læser højt og langsomt sammen i hans Social Story: "Jeg kysser og krammer ikke i dagtilbud". Han bliver rost for at takle situationen så godt og fortsætter med sit puslespil. Resten af dagen er jeg luft for ham. $\leftarrow$
}

Som sådan er kontaktsomhed også en form for samarbejde: Brugeren og pædagogen samspiller. Der er noget at give positiv respons på, fordi brugeren følger den pædagogiske strategi, når han selv regulerer sig efter dagtilbuddets struktur om at arbejde koncentreret ved at læse sin Social Story, og han får bekræftende kontakt med sin pædagog derved.

Umiddelbar, spontan kontaktsomhed er ikke kun noget der fremprovokeres af udefrakommende. Det er et gennemgående tema i mine feltnoter, at der reguleres via et løbende fors $\varnothing \mathrm{g}$ på at undgå kontakt, som afbryder strukturen, mens kontaktsomhed der understøtter strukturen er værdsat. For eksempel skal hver gerne passe sin egen mad til frokost. Nogen må have et æggeur til at indordne sig tiden afsat til aktiviteten, 
sådan at de spiser i stedet for at snakke eller lade sig aflede på andre måder, andre må spise med deres pædagog i enerum. Nogen udfylder bare situationen på tiltænkt vis. Man kan sige, at der foregår en 'øvelse i og gentagelse af uafbrudt koncentration om strukturen'. I min notesbog har jeg skrevet: "Bent bliver hurtigt færdig med at drikke sin te. Han rejser sig. "Smadder godt Bent", siger Mia "Så går vi ind og kigger på dit skema". Bent er allerede på vej. Eller: "Det var flot Benny, hvis du er færdig må du rydde op" som det ofte lyder som respons på spisning, der har forløbet planmæssigt i ro og koncentration om netop 'at spise'.

Uønsket kontakt opstår somme tider, når forskellige brugere samtidigt skal lave forskellige ting i det samme rum eller med udsyn til nogle andre, der er i gang med at lave noget andet. Engang imellem undgås kontakt og eventuel gensidig forstyrrelse ved simpelthen at placere brugerne med ryggen til hinanden eller med afskærmning med skillevægge, engang imellem er det ikke muligt, og så kan kontaktsomme situationer som følgende pludselig foregå:

\footnotetext{
$\rightarrow$ Bente er ved at spise frugt med Mads. Bag hende kører Bahood på kondicykel. Det bemærker Bente: "Det er Bahood. Hej Bahood" siger hun. Bahood, der lige har læst Social Story ('På kondicyklen er jeg god til at være stille og jeg bliver ved til uret ringer'), svarer ikke. Bente spørger Mads, om Bahood kan lide hende, eller om han slår. Mads siger, at alle i dagtilbud kan lide Bente, og at Bahood ikke slår, hvis hun ikke slår, og at det de hellere skal snakke om er, at hun får spist sin frugt. Bente er ikke helt færdig med at snakke om Bahood og siger hej flere gange. Mads snakker om Bentes frugt og når hun er stille lidt, at hun er god til at sidde og spise frugt i stedet for at sige hej hele tiden. Efterhånden gentager Bente, at hun er god til det, men tilføjer snart efter, at hun bare kigger på de andre. $\leftarrow$
}

Som sådan fortolkes brugernes kontaktsomme handlinger i Dagtilbud i nogen udstrækning som kontrast til selvstændighed, der værdsættes stærkt: "Han har jo arbejdet selvstændigt, han fik bare støtte, fordi det var for svær en opgave" rationaliseres det efter en situation, hvor en pædagog har været involveret i brugerens arbejdsopgave, ligesom Mads var det i Bentes spisningsaktivitet ovenfor.

Hvis brugeren er for(kert) kontaktsom - det vil sige er kontaktsom om noget andet end det, der er meningen, er brugeren ikke koncentreret og derfor afledelig fra det, der er opgaven/aktiviteten/arbejdet. Det kan være såvel pause, frugtspisning, frokost, som arbejdsbord eller i spontan glæde at synge med på en sang, mens man cykler kondicykel, eller at sige hej til en forbipasserende, mens man spiser frugt. Det er eksempler på brud på rutinen, og det vil sige på den forståelse af brugergruppen, som er gældende i Dagtilbud, der således 'medbestemmer' situationen - men også på medarbejdernes faglige viden om, hvad der er bedst for brugeren jf. deres metodebevidsthed og brugergruppedynamikker. 
Der kan identificeres forskellige grader af fortolkninger af brugernes gavn (profitering) af dagtilbuddets pædagogik som jeg fornemmer, at man er meget opmærksom på på et diskursivt niveau. Hermed mener jeg, at fortolkningerne af brugernes gavn egentlig ikke giver anledning til decideret at ændre praksis bortset fra i 'nødsituationer', hvor man er stærkt underbemandende for eksempel på grund af kursus og sygdom eller i særlige forhandlingslignende situationer. Det kan være Bruno der siger "Ikke nu. Bagefter." til at læse piktogram, fordi han kan huske rækkefølgen og derfor allerede ved, at han skal til at løse en bestemt rækkefølge af opgaver. Eller tre brugere som kommer på tur til en café i Tivoli, fordi fysioterapi og ridning er aflyst på grund af efterårsferien.

Der kan på baggrund af analysen af feltmaterialet identificeres følgende fire kategorier for grader af gavn: 1) De klart profiterende: for hvem det er kendetegnende, at deres hverdag altid har været organiseret meget struktureret, og er det alle deres steder, 2) De vurderede profiterende: dem for hvem metoden og tilgangen til dem er 'ny' og positivt ændre noget for dem, men vist nok mestendels er en praksis særligt knyttet til deres liv i Dagtilbud. 3) De måske profiterende: dem for hvem det er godt jf. deres autistiske karakteristika, men hvor graden af struktur eller metodens gennemførselskonsekvens kunne være anderledes Iøs, hvis man havde andre ressourcer eller en mere ensartet brugergruppe. Praksis er specielt knyttet til deres liv i Dagtilbud. 4) Dem, som egentligt skulle have været mødt med en ganske anden pædagogisk tilgang. Det kan være fejlvisiterede brugere.

Med det andet princip om metodebevidshed, der gør sig gældende i Dagtilbud, kan det være problematisk at være kontaktsom. I min notesbog har jeg skrevet om fredagsbilledlotteriet, hvor flere brugere samles: "Brikken viser et billede, der får Betty til at tænke på fastelavn. Hun spørger, hvornår det er. Maria siger, at det er om vinteren; men at nu skal de ikke snakke men spille. Banko siger Mia. Jaaah glæder Britt sig på hendes vegne og rækker tommelfingeren op i luften i retning mod Mia".

Selvom det altså umiddelbart lyder som om kontakt og dermed det 'at være social' undgås for enhver pris, kan man også sige, at den pædagogiske metode netop er karakteriseret ved en $h \varnothing j$ kontaktsomhedsgrad i mellem de forskellige opgaver. Det er i form af en ufravigelig struktur om, 'hvilken medarbejder brugeren er med'. Spørgsmål om Hvem er du med? eller Os to? er således typiske vendinger til daglig, der besegler 'vores tos sikre kontaktsomhed', om den vedvarende aktivitet brugeren gerne skal være i: "Så er han da aktiveret", lyder det, da Bjarne tager initiativ til at række ud efter en kop kaffe på bordet foran en pædagog, som sidder og skriver dagbog. Hun venter nær ved ham, til han har drukket ud, så følges de hånd i hånd ud af kantinen. Videre til næste aktivitet.

Bevidstheden om at være med nogen kan siges at være en beskyttende foranstaltning mod kaosoplevelser, for eksempel i det medarbejderne kalder kravsituationer, 
hvor bestemte opgaver skal løses jf. piktogramrækken. Men det er også en sikkerhed om, at der er en der straks tager over og tager ansvar, hvis det hele bliver for overvældende. Her i en såkaldt 'kædereaktion':

\footnotetext{
$\rightarrow$ Bea og Marit kommer gående på gangen. Bea siger højt "NEJ!" og slår sig selv hårdt i hovedet og stamper i gulvet. "Nej" siger hun igen, og da Marit siger, at hun ikke forstår, men at Bea nu skal 'have arbejdsbord', tager hun sin stol, løfter den og giver slip. Bang. Hun slår sig i hovedet igen. Marit henter Maria, som måske forstår, hvad Bea er vred over. Imens er Britt inde bag afskærmningen gået $i$ gang med at kaste med gummidyrene i sin sorteringsopgave. Hun bider i et af dem og i sine fingre. Maria beder Marit tage sig af Britt. Britt er vred og kaster flere gummidyr. Hun har rejst sig og skramler voldsomt med sin stol. I mellemtiden er Bea blevet forstået. Hun sidder veltilfreds i gang med sin arbejdsopgave. Pædagogen får Britts opmærksomhed. "Kig på mig" siger hun og forklarer, at "Det var Bea, der var vred. Det har ikke noget med dig at gøre". Lidt efter stiller Britt sin arbejdsopgave på plads og de to går sammen ud i gangen for at læse næste piktogram. $\leftarrow$
}

Når situationen er klaret, og alt igen er som det plejer, kan den daglige kontakt fortsætte. Nyt piktogram, ny arbejdsopgave: Lytte til musik, arbejdsbord, frugt, pause, dække bord, frokost, kaffe, og så videre. Alt sammen tæt fulgt, støttet eller observeret af den pædagog, brugeren er sammen med i dag. Så vidt muligt respektfuldt undgås det at forstyrre, distrahere eller afbryde de øvrige brugere med forskellige grader af behov for struktur, forudsigelighed, ro og orden i tilværelsens mange daglige udfordringer.

Kontaktsomhed i Dagtilbud er at imødekomme den enkelte bruger inden for flere samtidigt fungerende systemer: Brugerens, pædagogikkens/metodens og brugerforståelsens. For det første vedrørende brugeren, så har den enkelte indarbejdede rutiner og præferencer, som giver mening og holdepunkter i tilværelsen. Det er særligt for disse mennesker, hvis liv for de flestes vedkommende er præget af deres grad af autistisk funktionsforstyrrelse. Det kræver godt kendskab til den enkelte at være kontaktsom på brugerens præmisser. For det andet er det pædagogikkens/metodens med 1) overbevisninger om brugernes behov for og gavn af metoden. 2) viden om og erfaring med 'hvad der virker' på teoretisk og praktisk niveau, og 3) organisatoriske nødvendigheder bestemt af personaleressourcer og foranstaltninger den pågældende dag. Og for det tredje den gældende forståelse af de behov, en funktionsnedsættelse giver anledning til, som giver visse muligheder for kontaktsomhed, mens andre er uønskede.

\section{På 'hjemmedagen' klipper vi negle, renser ører og bliver vejet}

På 7. sal bor seks beboere. Deres hverdag er opdelt i hjemmeliv og dagtilbud. For tre af beboernes vedkommende ligger dagtilbuddet $\mathrm{i}$ huset, og er det samme, som jeg har skrevet om ovenfor. 
Hjemmelivet på 7. sal er præget af høj grad af kontaktsomhed. Det kræves der, når seks mennesker skal leve sammen og hver for sig med hver deres individuelle behov og præferencer. Alle beboere har behov for massiv støtte og hjælp til de fleste af hverdagens gøremål - hver på deres måde. Hver beboer har sin egen etværelses lejlighed, og for enden af gangen ligger det fælles køkken, opholdsrummet og stuen. Her spiser beboerne sammen, ser 'Nana' på DVD eller sidder og venter på den eftertragtede kaffe, holder øje med madlavningen i køkkenet, kigger blade eller dækker bord.

Det er min fortolkning, at der foregår så forskelligartet og situationsafhængig kontaktsomhed som der gør, netop fordi medarbejderne helt grundlæggende betragter 7 . sal som beboernes hjem, hvor der ligesom i alle andre menneskers hjem foregår forudsete og rutiniserede ting, såvel som uforudsete begivenheder opstår og kræver omstilling lige nu. Det er opdukkede situationer, der netop naturligt indtræffer, når flere mennesker lever deres liv sammen som beboere i et slags bofællesskab og med nødvendige medarbejdere til stede alle døgnets 24 timer, med de udfordringer det kan give menneskeligt og som pædagogisk ressource.

En så åben og fleksibel praksis i rammen 'hjem' indebærer, at kontaktsomheden kan være en stor udfordring i det daglige pædagogiske arbejde, hvor beboerne for hovedpartens vedkommende hovedsagligt bruger lyde og tegn og kun i mindre omfang et talesprog, hvis de overhovedet gør det.

Holdningen om ressourcen forbundet med beboernes liv sammen bruges i hverdagens pædagogik. Som Mille siger "Jeg venter med at servere morgenmad, til alle har badet færdig, for det er noget af det sociale, vi kan bidrage med at de får - at de sidder her og spiser sammen - men du vil sikkert opleve, at nogle af de andre gør det helt anderledes". Og det må jeg sande. Nogle dage er det alle på én gang, med pædagogen der 'serverer' for hver enkelt, andre dage er det enkeltvis og beboerne selv, der så vidt det er en individuel mulighed øser op.

Det er, ligesom i alle $\varnothing v$ rige situationer fra bad til tur, ikke entydigt på nogen helt bestemt måde, den enkelte medarbejders kontakt med beboeren foregår. Det er for eksempel Bea, som med den ene pædagog får rakt tøjet, så det kommer til at vende rigtigt, mens hun med en anden selv tager det rigtigt på, mens de er sammen om at koncentrere sig om, at det er det at tage tøj på, det drejer sig om nu og her. Men det kan sagtens være, at situationerne kommer til at ligne hinanden, fordi medarbejderne har et indgående kendskab til den enkeltes præferencer, styrker og indsatområder, og fordi beboerne selv viser, at de foretrækker noget bestemt. For eksempel når Bo hen på eftermiddagen henter en af medarbejderne eller feltarbejderen og med tegn viser, han vil have redt hår, eller Bea løfter armen for den ny vikar, fordi hun gerne vil have deodorant på, inden hun skal hen til håndvasken og have børstet tænder. 
Eftersom beboernes handicap er autistisk relateret, er kontaktsomhed i høj grad noget, der indebærer medarbejdernes deltagelse. Når det er beboerens initiativ, består kontakten ofte i en kontant forsikring om, at tingene skal ske på den måde, som man kan forvente eller har fået stillet i udsigt, således at en aftale bekræftes, eller en rutine bestyrkes ved gentagelsen: "Ja Bo, i morgen når du vågner, skal du have kakao, men først skal du have aftensmad og kaffe og så skal du sove".

Herunder er det Britt, som hver aften får et bad, der vil vide om hun også i aften kommer i bad. Samtidig tager hun initiativ til en snak om, hvem hun kan regne med er der sammen med hende både $\mathrm{i}$ aften og på hendes hjemmedag, og hun deltager i samtalen i køkkenet sådan, at hun får den attraktive opgave at slukke for opvaskemaskinen, når den bipper:

$\rightarrow$ Mogens og Majken aftaler 'det praktiske': hvem der skal ordne madpakker og hvem der skal gå tur sammen med beboerne. Britt kommer ud i køkkenet. Hun spørger om aftenbad. Majken siger, at det skal hun få, inden hun skal sove. Så vil Britt høre, hvem hun er sammen med på sin hjemmedag. Det er Mogens, som bekræfter, at de to jo har aftalt, at de skal i FætterBR og købe noget. "Ja" siger Britt højt med bekræftende armbevægelser og et stort nik med hele kroppen.

Britt kigger intenst på Majken: Hjælpe mig? Anden dag?

Majken: Ja jeg kommer igen i morgen Britt

Britt: Ja. Dig og mig nu?

Majken: Ja Britt, det er dig og mig nu

Britt konstaterende: Hjemmedag Mogens.

Majken: Har du spurgt Mogens?

Britt: Ja

Britt bliver i køkkenet. Hun siger "Biiip" og de aftaler, at det er hende, der skal slukke på knappen, når maskinen siger bip. $\leftarrow$

Men det kan også sagtens være der 'jokes' i en situation, uden at det skaber kaos og brud for beboeren:

\footnotetext{
$\rightarrow$ Bea er i gang med sit aftenbad. Majken hjælper med at skylle sæben af under armene. Bea slukker for vandet og siger "I morgen".

Majken: Ja, det er Beas hjemmedag i morgen, og så skal vi på café, har vi aftalt.

Bea siger en hel masse lyde, hun snakker vist om sin hjemmedag, tror jeg. Hun ser glad ud. Lidt efter siger hun mellem alle lydene "dessert".

Majken: Ja, jeg tror det er is

Bea: NEJ!

Majken: Nåhh Bea, kan du bedre lide kage måske?

Bea: Jah!! Ł
}

Ofte henvender beboerne sig altså til medarbejderne - direkte eller indirekte - for at opnå kontakt om noget, der er vigtigt at få bekræftet eller for at snakke, lave aftaler eller bare være sammen i en situation. Det kan være, Britt kommer hen og snakker om 
noget, hun har oplevet med netop den pædagog: "Drikkedunk. Iskold mælk" siger hun og så får de en snak: "Ja du fik iskold mælk i drikkedunken, men nu er den til opvask." "Biiip" siger Britt og får indforstået svaret: "Ja Britt, når opvaskemaskinen er færdig, må du hjælpe med at slukke, når den siger bip", eller Børge vil høre, hvad vi snakker om, for at få forsikret at alt er, som det skal være: "Nej, det er ikke dig vi snakker om Børge" eller "Vi snakker om, at du er sød Børge" - "Nå" siger han og går tilbage i lejligheden. Eller Bea kommer hen til feltarbejderen og siger "Krammer", og så er det det, vi gør.

Som i feltuddraget ovenfor med samtale om Beas hjemmedag, er det ofte beboeren der pludselig siger noget, der er kontaktsomt, eller kan fortolkes som anledning til kontakt. Medarbejderne griber lydhørt situationen og gør noget ud af det med tilføjelser og uddybninger, der er afpasset den enkeltes behov og formåen: "Når du har taget tøj på, skal du redde seng og bagefter er der morgenmad", siger Mille, da Benny står og ser spørgende på hende efter badet.

Men kontaktsomhed er også medarbejdernes initiativ. Så er det en samspilsform, der for eksempel er pædagogisk understøttende af selvhjulpenhed med støtte: Bea dækker bord, men afventer hele tiden Mogens instruktion: "Tager du handsker på?", "Kan du dele tallerkner rundt?" ... Samtidig kan kontakt initieret af medarbejderne indebære krav om at afbryde en uheldig rutine: "Bo, tag din tallerken med ud i opvaskemaskinen" afbryder pædagogen høje klagende lyde over den svære situation med at spise, eller når Benny forgæves skraber og skraber mere mad af den for længst tomme tallerken: "Den er tom Benny. Du må rejse dig, hvis du er færdig". Eller Børge, som rejser sig for at rette på ketchupflaskens placering på bordet, eller på feltarbejderes notesbog på stolen der åbenbart skal vendes om, for at ligge lige efter hans hoved: "Det er fint Børge, sæt du dig bare ned igen", lyder det.

Men det er også en individuel mulighed for nær, venlig, 'venskabelig' kontakt, som ligner nære forhold 'i verden uden for Botilbud'. Ofte foregår det, hvis medarbejderen er meget dygtig til tegn-til-tale. Men måske er det især i form af 'nære relationer i ualmindelige situationer'. Det er situationer, der fremmer beboerens kontaktsomhed og foregår særligt i tosomhed på badeværelset morgen og aften:

$\rightarrow$ Det er Britts morgenbad. Hun bruser sig. Martha kommer ind på badeværelset: Er det lidt for varmt vandet?

Britt: Ja.

Martha: Kan du skrue lidt ned så?

Det gør Britt og Martha siger, at Britt skal gøre sit hår vådt. Men Britt kigger Martha dybt i øjnene. Det er som om, der kun er de to i verden, og som om Britt næsten spejler sig i Martha, som lægger hovedet lidt tilbage for at vise Britt, at sådan skal hun få håret ind under bruseren. Britt gør som 
Martha gør og smiler. Martha tager hårshampoo og begynder at vaske Britts hår, mens Britt stadig ser nøje på Marthas ansigt. Martha laver shampoo-strithårs-frisure i Britts hår.

Martha: Prøv at se dig i spejlet. Ser du ikke sjov ud?

Britt kigger og griner, men hendes fokus er alligevel på Martha, på deres samvær. Hun skyller sit hår og Martha skyller efter. Hun gør klar med sæbeflasken og Britt siger "Sæbe"

Martha: Ja. Britt, hvis du slukker for vandet, så får du sæbeskum

Britt: Dig og mig?

Martha: Ja Britt det er dig og mig. $\leftarrow$

I den stille lørdagsstemning viser kontaktsomhed sig fra sit mest sigende mønster på 7 . sal: Det er som mulighed. Det betyder, at den er individuelt rettet, tilpasset den enkelte, svar på et behov, når det dukker op og lige inden for rækkevidde. Det kan være nogen, der kan bekræfte dagsrytmen (Bo), nogen at snakke med (Britt), en at ordne den gode madbakke med, stille følges med (Benny), nogen at få spontan glæde bekræftet fra, nogen der igen og igen husker på, at det er vigtigt at drikke vand (Bea), nogen der er som forventet at være sammen med (Børge), en der udtrykker en følelse som svar på en lyd (Bjørn).

Til tider er beboernes kontaktsomhed rettet mod andre beboere, enten konkret som i feltuddraget i slutningen af indledningen, hvor Bo kontakter Bea, eller ved gensidig påvirkning som giver anledning til kontaktsomhed. Det er for eksempel, når Bjørn er ude efter de andre beboeres mad og ikke tager et nej for et afslag, så det fortsætter og fortsætter med gensidig opmærksomhed, indtil alle er færdig med at spise. Eller når Bjørn og Britt pludselig skåler i kaffe.

I indledningen til afsnittet om kontaktsomhed her på 7. sal fremhævede jeg, at man grundlæggende arbejder med beboerens hjem som omdrejningspunkt i det pædagogiske arbejde, med de rutiner og den tryghed det indebærer for beboerne, sammen med en parathed til det uforudsigelige, det der opstår, de muligheder der byder sig, og de ting der forandrer en rutine: Det kan være en pludselig mulighed for en ledig bus, en påklædning i en nødvendig håndevending i stedet for med masser af tid, en ekstra beboer med ned i Netto, alle på en spontan tur på legepladsen før aftensmad ...

Overfor sådan en fleksibel pædagogik gør sig en sideløbende mere institutionel pædagogisk handlingsform gældende, som markerer, at det godt nok er hjemme for nogen med stor respekt for dette, men at det også er en arbejdsplads, hvor nogen er genstand for nogle andres arbejde.

Hjemmedagen er et eksempel herpå. Den i beboerens forståelse så eftertragtede hjemmedag, hvor noget særligt lækkert og forskelligt fra uge til uge kan ske: en favoritret til frokost, en tur i FætterBR eller lignende sammen med den pædagog, der er på arbejde, er også kilde til institutionalisering. Da den ny vikar skal 'læres op' på antropo- 
logens anden feltarbejdsdag, lyder det ude på badeværelset: "Om hjemmedagen får de klippet negle, renset ører og bliver vejet". Det er altså dagen for praktiske gøremål.

Men det tilstræbes samtidig, at det er kontakt med pædagogen på brugerens præmisser: "Det er Bjørns hjemmedag, hvordan kan vi bedst tilrettelægge det, så det er hans dag?" spørger Mille, som også skal nå at skrive et oplæg til et møde om en anden beboer og instruere en ny pædagog i medicinskabet. Således en pædagogik hvor der tænkes i kontaktsomt at give beboeren en hjemmedag på hans præmisser, samtidig med at alt det praktiske skal afvikles. Der skal ske noget beboeren vil, men samtidig er det med bestemte rutiner, som sikrer at vasketøj, ørerensning mv. bliver ordnet regelmæssigt. Så bliver beboeren arbejdsobjekt, hvilket også kan genkendes i måder at tale om arbejdet under arbejdet: "Jeg beder dem altid om at sætte foden på wcbrættet, det er en god balanceøvelse, som autister har rigtig godt af, og så skåner det min ryg", siger en af pædagogerne, som forklaring på hendes praksis i forbindelse med demonstration af 'tørring efter bad'.

Man kan måske tale om at organisatoriske nødvendigheder bliver til en institution i hjemmet og i arbejdet med beboeren, som netop ikke er fravigelige sådan som alt det andet, hvor man er åben over for alsidighed, forhandlinger, forventer det uventede, og dermed gør uendelige kontaktformer mulige. På den måde bliver hjemmedagen, og derfor i nogen udstrækning det pædagogiske, en institution mere end Botilbud på 7. sal er det - for det er nogens hjem.

Man kan sige, at i jo højere grad medarbejderne er i stand til at forstå og imødekomme beboerens kontakt - har den fornødne tid, ikke er nødt til at være optaget af noget andet i øjeblikket, ikke har en anden 'dagsorden' med kontakten i hovedet om, hvad der 'egentligt' ville være rigtig godt der foregik lige nu etc. - jo mindre tilbøjelig vil man være til at omtolke, ombruge, ignorere, ikke forstå, overse beboerens kontaktsomhed, til noget andet.

Herunder i de to tekstbokse er der dels tale om en meget velfungerende gensidig kontaktsomhed, som er et mønster i feltmaterialet, hvor beboeren 'pludselig kan kommunikere på et nyt meningsfuldt niveau', dels om en situation hvor der foregår en omtolkning af kontaktsomheden, som jeg ovenfor har antydet som mønster. Her brydes kontaktmuligheden, men gennemføres til sidst ved beboerens vedholdende arbejde med at få den ønskede konktakt til at lykkes. Men det er klart at en omtolkning godt kan være pædagogisk nødvendig og helt hensigtsmæssig for at bryde et uhensigtsmæssigt mønster, der er selvskadende eller umuligt at bryde for beboeren selv. Det kan også være nødvendigt at skabe en 'pause' for at have overskud til at gøre et nyt fors $\varnothing \mathrm{g}$ på at være en kontaktsom pædagog. 
Det er fredag eftermiddag. Britt og et par andre beboere er ved at drikke kaffe. Britt skåler med Bjørn. Hun vender sig om mod mig og siger "hjælpe mig?". "Hvad skal jeg hjælpe med?". Minna kommer ind i stuen med mere kaffe. Britt gentager "Hjælpe mig?" og ser på Minna.

Minna: Hvad skal jeg hjælpe dig med? Britt viser tegn for 'børste tænder' Minna: Ja, inden du skal sove [tegn], skal du have børstet tænder [tegn], og det vil jeg gerne hjælpe dig med [tegn]. Men først skal vi spise [tegn], og så skal vi have fredagsslik [tegn]. Britt spørger, om hun må drikke kaffe [tegn] i lejligheden [tegn]

Minna: Ja, du må drikke kaffe [tegn] og spise slik [tegn] i lejligheden. Og vil du så høre musik [tegn]?

Britt: Ja! Britt viser ja med hele kroppen.

Minna giver tegn om, at det er en aftale. Britt kommer frem med tommelfingeren og de trykker tommelfinger. Hun griner højt og smiler glad.
Det er torsdag morgen. Alle har spist morgenmad eller er ved det. Bjørn er for længst færdig. Han rejser sig fra en stol. Han har sit glas i hånden. Han er på vej mod køkkenet.

Mille afskærer ham vejen ved at lukke døren til i et snuptag. Bjørn vender sig om til sin stol igen.

Da døren lidt senere står åben igen, rejser Bjørn sig og dørlukningen gentager sig: "Bare ærgerligt Bjørn" siger Mille til Bjørn, som er så fokuseret på at spise, at han spiser bananer med skræl på, hvis han kan få fat i dem. Han har adgang forbudt til køkkenet. Bjørn vender om: Rød i hovedet, vrede lyde ned ad gangen. Pædagogerne snakker med de andre beboere. Lang tid efter kommer Bjørn tilbage med et glas vand. Han går helt hen tæt til Britt ved spisebordet, og de skåler fornøjet med hinanden. Pædagogen konstaterer: "Nå, Bjørn har hentet vand på sit badeværelse, gad vide om han har slukket igen". 


\section{Afslutning}

Når jeg sidder eller står i bussen i myldretiden, morgen eller tidlig eftermiddag på vej til min felt, er jeg spændt på, hvad dagen vil bringe. Hvordan skal jeg mon indgå i dagens kontaktformer? Vil jeg være i stand til og have mulighed for at være passende kontaktsom til at fatte, hvad der foregår?

Gennem byens pulsslag, tæt op af mange mennesker der taler mange sprog, bussen der dytter af fodgængere, der skynder sig over for rødt, med cyklister der suser af sted i deres grønne bølge, køer af biler, taxaerne, forbi de 'forevigede' unge stemmer med deres tegn på den gule mur om et nu mistet slags hjemme på Jagtvej 69, er jeg på vej mod nogle andre menneskers hjem og arbejdsplads. Et sted kendetegnet ved respekt for forskellighed, hvor man kan være den, man er, og udtrykke det på sin måde - med skæve kroppe, svære lyde, tegn og tale, sagte og højt, i vrede og glæde. København summer af liv. Her midt i byen går jeg ned ad vejen mod min felt, derinde kan livet synes stille - men med de mange kontaktformer og den udstrakte kontaktsomhed, jeg har fået lov at følge og være del i, er der så langt fra stille.

Eller jeg er på vej hjem eftermiddag eller aften. I eftertænksomhed: hvad ved jeg noget om i dag, som jeg ikke vidste i går. Hvilke nye spørgsmål og svar har jeg fået. Jeg glemmer næsten at stå af bussen. Ringer lidt sent med stopklokken, fyldt som jeg er med forskelligartede situationer og fors $\varnothing$ gsvise fortolkninger af sammenhænge mellem dagenes og ugernes oplevelser. For jeg er allerede under feltarbejdet sikker på, at kontaktsomhed er meget mere omfattende, end jeg har kunnet nå at erfare. Selv i min position med ret til at involvere mig dybt eller trække mig og bare kigge og opleve på afstand, og med mulighed for at forfølge situationer uden at være bundet af dagens forskellige gøremål og mange forskellige behov og kontaktformer, at få øje på og forholde mig til med handling sådan som medarbejderne.

Efter feltarbejdet og med timer bag skrivebordet og foran computeren må én konklusion - konklusionen på min historie om det socialpædagogiske arbejde, være, at der hele tiden foregår meget mere kontakt, mere kommunikation, at der bliver sagt og signaleret meget mere, end det er muligt at fange og forholde sig til i det omfattende, mangesidede og krævende pædagogiske arbejde, der hele tiden foregår i bo- og dagtilbud.

Fordi det ofte er enkelte ord eller et tegn der pludselig tales med og at disse ord eller tegn er del af noget mere. Endvidere er kommunikationen ofte ikke i hele sit udtryk udadvendt mod omverden eller en bestemt person i omgivelserne.

Men det ligner kontaktsomhed, og det er noget det er mulig at tage op, svare på og gøre til et kontaktsomt forhold, hvis man har $\varnothing$ je for det og ser muligheden i situationen, hvis man selv er kontaktsom, og hvis metoder og definitioner af den pædagogiske opgave tillader det. 
Det kræver et omfattende, nuanceret kendskab til den enkeltes kontaktformer og rigtig gode kigge-, lytte-, fortolknings- og ofte også 'gætteevner'.

Ofte er kontakten (hvis den fortolkes som sådan) altså ikke direkte forståelig for omverdenen.

Slet ikke hvis de mange forskellige medarbejdere, med de mange forskellige baggrunde, ikke har et omfattende kendskab til tegn-til-tale, der benyttes af rigtig mange beboere og brugere, som i den forstand er meget kontaktsomme over for omgivelserne, der gentagne gang må give fortabt. Ikke i mangel på vilje til at forstå og være kontaktsom med beboeren eller brugeren, men i afmagt må de opgive og lade kontaktmuligheden passere eller måske omforbruge den til noget andet.

Derforuden er kontakten ofte tidsmæssigt forskudt.

Det betyder, at kontaktfors $\varnothing \mathrm{g}$ kan vedrøre noget, der er sket flere timer forinden, men pludselig følges op langt senere. Måske med så stort tidsinterval at der er skiftet medarbejdere undervejs, eller at der simpelthen kommunikeres om noget, der foregår eller hører til i en helt anden sammenhæng for eksempel i hjemmet, som hører til i dagtilbud eller omvendt og derfor er uforståeligt for medarbejderne.

Det er under alle omstændigheder helt klart at tegn bliver brugt meget mere omfattende af brugere og beboere, end de bliver besvaret, opfattet eller forstået af medarbejderne. Som sådan, er der alene der store kommunikative udfordringer for medarbejderne, som ikke forstår. Problemet er, at det overføres til at være brugerens eller beboerens problem, for det er dem, som sidder tilbage uden at være blevet forstået og vel uden mulighed for at blive det. De kan ikke sige det på en anden måde. Der er kun de ord, lyde og tegn eller piktogrammer, der er til rådighed. Det kan føre til vrede, frustration, selvdestruktive handlinger eller simpelthen opgivelse og stille resignation.

Konklusionen på feltberetningen om kontaktsomhed i det socialpædagogiske arbejde, som i vidt omfang lykkes og er en væsentlig og helt grundlæggende del af livet i bo- og dagtilbud er, at det ligesom det er kontakt der oppebærer det, man netop kan i mange forskellige pædagogiske sammenhænge, på mange forskellige måder og med mange forskellige begrundelser, også er det, der er et pædagogisk problem, og derfor er der action må tages. Alle er kontaktsomme - humørfyldt og lystbetonet, stille, afslappet eller dovent, ked af det eller vred - Og de situationer fortolkes hele tiden. Kontaktsomhed er både en henvendelse, og det er en respons på en henvendelse. Det er både hverdagsliv når man bare 'er', og pædagogik når nogen vil nogen noget, og det er socialt, og det er helt alene i verden, når ingen forstår. 


\section{Kapitel 5}

\section{Det daglige arbejde - opgaver og ansvar}

Efter 'den udefrakommendes' subjektive beskrivelser af dagligdagen i bo- og dagtilbud, er temaet i kapitel 5 et mere 'nøgternt' indblik i medarbejdernes daglige gøremål i botilbuddene.

Hvilke konkrete arbejdsopgaver har de med hensyn til omsorgsaktiviteter og mere fritidsrettede aktiviteter såsom at se fjernsyn sammen med beboerne eller spille spil, og hvilket medansvar og pædagogisk vanskelige situationer opleves i det daglige, når omsorgsmedhjælpere og pædagoger skal vurdere det?

\section{Medansvar i dagligdagen}

Spørges medarbejderne ind til, hvilket omfang de personligt oplever medansvar for planlægning af de daglige omsorgsopgaver i forhold til beboerne, er svaret 'i høj grad'. Fire ud af fem medarbejdere ( 79 \%) svarer således, mens den sidste femtedel svarer ' $\mathrm{i}$ nogen grad', og kun $1 \%$ mener at de 'slet ikke' eller kun 'i ringe grad' har medansvar for planlægningen af den daglige omsorg.

Denne svarfordeling fremgår - sammen med fire andre spørgsmål om medansvar af tabel 15:

Tabel 15. I hvilket omfang har du medansvar for planlægning i forhold til beboere/brugere? ${ }^{54}$

\begin{tabular}{|l|c|c|c|c|}
\hline $\begin{array}{l}\text { I hvilket omfang har du medan- } \\
\text { svar for planlægning i } \\
\text { forhold til beboere/ brugere }\end{array}$ & $\begin{array}{c}\text { I høj } \\
\text { grad } \\
\text { Alle i \% }\end{array}$ & $\begin{array}{c}\text { I nogen } \\
\text { grad } \\
\text { Alle i \% }\end{array}$ & $\begin{array}{c}\text { I ringe } \\
\text { grad } \\
\text { Alle i \% }\end{array}$ & $\begin{array}{c}\text { Slet } \\
\text { I kke } \\
\text { Alle i \% }\end{array}$ \\
\hline I forhold til den daglige omsorg & 79 & 20 & 0 & 1 \\
\hline $\begin{array}{l}\text { I forhold til den daglige beskæfti- } \\
\text { gelse }\end{array}$ & 43 & 44 & 9 & 4 \\
\hline $\begin{array}{l}\text { I forhold til beboernes mulighed for } \\
\text { kommunikation på egne betingelser }\end{array}$ & 51 & 39 & 7 & 2 \\
\hline $\begin{array}{l}\text { I forhold til beboernes mulighed for } \\
\text { stimulering/udfordringer efter egne } \\
\text { ønsker/behov }\end{array}$ & 45 & 41 & 12 & 2 \\
\hline $\begin{array}{l}\text { I forhold til beboernes mulighed for } \\
\text { at træffe egne beslutninger }\end{array}$ & 48 & 39 & 11 & 2 \\
\hline
\end{tabular}

\footnotetext{
${ }^{54}$ Også i dette kapitel er svarkategorierne 'Denne faktor er ikke relevant for mig' og 'Ved ikke' neutraliseret i nogle af tabellerne, således at der kun er medtaget medarbejdere, der har erfaring ift. spørgsmålet og har taget aktivt stilling hertil. Se bilag 3 for den samlede svarfordeling.
} 
Det generelle indtryk af svarfordelinger på spørgsmål omkring medansvar i forhold til planlægning af de daglige aktiviteter sammen med beboerne og planlægning af 'individuelle udviklingsmuligheder' for beboerne (støtte til at de kan træffe egne beslutninger eller får muligheder for udfordringer der matcher deres ønsker og behov) er, at omkring halvdelen af medarbejderne mener de 'i høj grad' har aktivt medansvar for planlægning af sådanne pædagogiske indsatser, mens de fleste af de $\varnothing v$ vrige mener ' $i$ nogen grad', og kun omkring hver tiende medarbejder sætter kryds ved 'i ringe grad' eller slet ikke.

Tabel 15 er samlet for omsorgsmedhjælpere og pædagoger og på et spørgsmål omkring medansvar i forhold til planlægning er det relevant at se, om der her er forskelle i svarmønstrene blandt pædagoger og omsorgsmedhjælpere, især omkring hvorvidt der 'i høj grad' opleves medansvar.

Her viser det sig at være et af de spørgsmål, hvor der kan iagttages nogle af de mest markante forskelle blandt unders $\emptyset$ gelsens mange spørgsmål.

Bortset fra spørgsmålet om medansvar for planlægning 'I forhold til den daglige beskæftigelse', hvor der kun er 6 \% forskel på andelen af pædagoger og omsorgsmedhjælpere, der svarer 'i høj grad', er forskellene i de fire andre delspørgsmål mellem 20 og $30 \%$, jf. følgende uddrag af tabel 15 :

\begin{tabular}{|c|c|}
\hline $\begin{array}{l}\text { I hvilket omfang har du medan- } \\
\text { svar for planlægning i } \\
\text { forhold til beboere/ brugere }\end{array}$ & $\begin{array}{c}\text { I høj } \\
\text { grad } \\
\text { Antal i \% } \\
\end{array}$ \\
\hline \multicolumn{2}{|l|}{ I forhold til den daglige omsorg } \\
\hline Pædagoger & 85 \\
\hline Omsorgsmedhjælpere & 59 \\
\hline \multicolumn{2}{|l|}{$\begin{array}{l}\text { I forhold til den daglige beskæfti- } \\
\text { gelse }\end{array}$} \\
\hline Pædagoger & 44 \\
\hline Omsorgsmedhjælpere & 38 \\
\hline \multicolumn{2}{|l|}{$\begin{array}{l}\text { I forhold til beboernes mulighed for } \\
\text { kommunikation på egne betingelser }\end{array}$} \\
\hline Pædagoger & 59 \\
\hline Omsorgsmedhjælpere & 29 \\
\hline \multicolumn{2}{|l|}{$\begin{array}{l}\text { I forhold til beboernes mulighed for } \\
\text { stimulering/udfordringer efter egne } \\
\text { ønsker/behov }\end{array}$} \\
\hline Pædagoger & 50 \\
\hline Omsorgsmedhjælpere & 29 \\
\hline \multicolumn{2}{|l|}{$\begin{array}{l}\text { I forhold til beboernes mulighed for } \\
\text { at træffe egne beslutninger }\end{array}$} \\
\hline Pædagoger & 55 \\
\hline Omsorgsmedhjælpere & 32 \\
\hline
\end{tabular}


Vurderingen af en høj grad af medansvar for planlægning af de pædagogiske indsatser er således et af de områder, hvor forskelle viser sig mellem de to faggrupper, og mest overraskende er, at det også gælder i forhold til planlægning af 'den daglige omsorg', hvor der nok er et flertal blandt begge medarbejdergrupper, der svarer 'i høj grad', men med en margin mellem dem på $26 \%$, idet $85 \%$ af pædagogerne svarer således mod 'kun' $59 \%$ af omsorgsmedhjælperne.

\section{De daglige gøremål}

Et af de mere omfangsrige spørgsmål i undersøgelsen angår de daglige gøremål. I alt 24 underspørgsmål omkring omsorgsaktiviteter, praktiske aktiviteter og mere fritidsprægede aktiviteter, som samlet giver et meget konkret billede af, hvor ofte medarbejderne i dagligdagen er beskæftiget med diverse praktiske opgaver og fælles aktiviteter.

I modsætning til underspørgsmålet om medansvar er der her i langt hovedparten af underspørgsmålene marginale forskelle i svarmønstrene mellem pædagoger og omsorgsmedhjælpere. Især i forhold til de daglige praktiske omsorgsopgaver som at bistå med toiletbes $\varnothing$ g, ordne beboernes tøj o.l. er det noget, hovedparten af såvel pædagoger som omsorgsmedhjælpere deltager i dagligt ${ }^{55}$, og den samlede svarfordeling på 5 omsorgsspørgsmål er:

Tabel 16. Omfang af deltagelse i aktiviteter og opgaver? (uddrag)

\begin{tabular}{|l|c|c|c|c|}
\hline $\begin{array}{l}\text { I hvilket omfang } \\
\text { deltager du i føl- } \\
\text { gende aktiviteter } \\
\text { og opgaver? }\end{array}$ & $\begin{array}{c}\text { En eller fle- } \\
\text { re gange } \\
\text { om } \\
\text { dagen } \\
\text { Alle i \% }\end{array}$ & $\begin{array}{c}\text { Nogle } \\
\text { gange } \\
\text { om } \\
\text { ugen } \\
\text { Alle i \% }\end{array}$ & $\begin{array}{c}\text { Mindre } \\
\text { end én } \\
\text { gang om } \\
\text { ugen } \\
\text { Alle i \% }\end{array}$ & $\begin{array}{c}\text { Aldrig eller } \\
\text { har ikke } \\
\text { denne akti- } \\
\text { vitet } \\
\text { Alle i \% }\end{array}$ \\
\hline $\begin{array}{l}\text { A. Omsorgsrettede } \\
\text { aktiviteter }\end{array}$ & 71 & 17 & 7 & 6 \\
\hline $\begin{array}{l}\text { Omsorg ifm. bad og } \\
\text { personhygiejne }\end{array}$ & 61 & 9 & 3 & 28 \\
\hline $\begin{array}{l}\text { Omsorg som toilet- } \\
\text { besøg, bleskift o.l. }\end{array}$ & 58 & 10 & 7 & 25 \\
\hline $\begin{array}{l}\text { Hjælp til af- og på- } \\
\text { klædning }\end{array}$ & 60 & 26 & 11 & 3 \\
\hline $\begin{array}{l}\text { Ordner beboernes tøj } \\
\text { og lejlighed }\end{array}$ & 66 & 18 & 3 & 12 \\
\hline $\begin{array}{l}\text { Lægge beboere til at } \\
\text { sove/vækker dem }\end{array}$ & & &
\end{tabular}

Tabel 16 giver et indblik i, at de uomgængelige omsorgsrettede aktiviteter ikke uventet fylder en del i det daglige for hovedparten af medarbejderne, og at der er omkring en fjerdedel, der markerer, at de aldrig udfører omsorgsopgaver såsom bistand ved toi-

\footnotetext{
${ }^{55}$ I Bilag 3 er en oversigt delt op mellem de to faggrupper.
} 
letbesøg eller af- og påklædning, skyldes formentlig, at der her er tale om medarbejdere med specifikke funktioner eksempelvis i dagtilbud eller som nattevagt.

Lidt mere varieret er hyppigheden af daglige opgaver, når der spørges ind til en række praktiske aktiviteter og administrative opgaver.

Her er svarfordelingen på 9 delspørgsmål:

Tabel 16. Omfang af deltagelse i aktiviteter og opgaver? (uddrag)

\begin{tabular}{|l|c|c|c|c|}
\hline $\begin{array}{l}\text { I hvilket omfang } \\
\text { deltager du i føl- } \\
\text { gende aktiviteter } \\
\text { og opgaver? }\end{array}$ & $\begin{array}{c}\text { En eller fle- } \\
\text { re gange } \\
\text { om } \\
\text { dagen } \\
\text { Alle i \% }\end{array}$ & $\begin{array}{c}\text { Nogle } \\
\text { gange } \\
\text { om } \\
\text { ugen } \\
\text { Alle i \% }\end{array}$ & $\begin{array}{c}\text { Mindre } \\
\text { end én } \\
\text { gang om } \\
\text { ugen } \\
\text { Alle i \% }\end{array}$ & $\begin{array}{c}\text { Aldrig eller } \\
\text { har ikke } \\
\text { denne akti- } \\
\text { vitet } \\
\text { Alle i \% }\end{array}$ \\
\hline $\begin{array}{l}\text { C. Praktiske aktivi- } \\
\text { teter }\end{array}$ & 56 & 29 & 8 & 8 \\
\hline Madlavning & 66 & 20 & 9 & 5 \\
\hline $\begin{array}{l}\text { Oprydning i fælles- } \\
\text { arealer }\end{array}$ & 66 & 20 & 10 & 4 \\
\hline $\begin{array}{l}\text { Borddæk- } \\
\text { ning/afrydning }\end{array}$ & 38 & 24 & 24 & 14 \\
\hline $\begin{array}{l}\text { Opvask } \\
\text { Rengøring }\end{array}$ & 25 & 40 & 25 & 10 \\
\hline $\begin{array}{l}\text { Køber ind for bebo- } \\
\text { erne }\end{array}$ & 6 & 16 & 49 & 29 \\
\hline Reparationer & 50 & 30 & 13 & 6 \\
\hline $\begin{array}{l}\text { Administrative opga- } \\
\text { ver }\end{array}$ & 5 & 51 & 33 & 7 \\
\hline $\begin{array}{l}\text { Personalemøder og } \\
\text { lign. }\end{array}$ & 5 & & 7 & 5 \\
\hline
\end{tabular}

Praktiske arbejdsopgaver i tilknytning til spisning og oprydning i fællesarealer hører til de daglige gøremål for de fleste medarbejdere, og kun de færreste (mellem 12-16 \%) markerer, at de deltager heri mindre end en gang ugentligt eller aldrig.

Noget færre - men dog typisk omkring to tredjedele af medarbejderne - deltager som minimum 'nogle gange ugentligt' med opgaver som rengøring, indkøb for eller sammen med beboerne, og så selvfølgelig administrative opgaver (80 \%) og personalemøder (60 \%), og kun på spørgsmålet som pædagogen som 'handyman' med småreparationer, der det over halvdelen af medarbejderne, der mindre end en gang ugentligt eller aldrig udfører sådanne opgaver.

Kun under et af delspørgsmålene er der en markant forskel i svarfordelingen mellem pædagoger og omsorgsmedhjælpere, nemlig omkring de administrative opgaver, hvor der er langt flere pædagoger, for hvem det er noget, der laves en eller flere gange 
dagligt, nemlig $56 \%$ mod $33 \%$ blandt omsorgsmedhjælpere. Flertallet af pædagoger har således denne daglige funktion mod en tredjedel af omsorgsmedhjælperne, og ses der her på den anden ende af skalaen, er det kun $1 \%$ af pædagogerne, der sætter kryds ved 'mindre end en gang om ugen' eller 'aldrig' mod $27 \%$ - mere end en fjerdedel - af omsorgsmedhjælperne.

Den sidste gruppe af spørgsmål omkring dagligdagens gøremål er 10 delspørgsmål rettet mod mere fritidsprægede aktiviteter sammen med beboerne.

Svarmønstrene er her:

Tabel 16. Omfang af deltagelse i aktiviteter og opgaver? (uddrag)

\begin{tabular}{|l|c|c|c|c|}
\hline $\begin{array}{l}\text { I hvilket omfang } \\
\text { deltager du i føl- } \\
\text { gende aktiviteter } \\
\text { og opgaver? }\end{array}$ & $\begin{array}{c}\text { En eller fle- } \\
\text { re gange } \\
\text { om } \\
\text { dagen } \\
\text { Alle i \% }\end{array}$ & $\begin{array}{c}\text { Nogle } \\
\text { gange } \\
\text { om } \\
\text { ugen } \\
\text { Alle i \% }\end{array}$ & $\begin{array}{c}\text { Mindre } \\
\text { end én } \\
\text { gang om } \\
\text { ugen } \\
\text { Alle i \% }\end{array}$ & $\begin{array}{c}\text { Aldrig eller } \\
\text { har ikke } \\
\text { denne akti- } \\
\text { vitet } \\
\text { Alle i \% }\end{array}$ \\
\hline $\begin{array}{l}\text { B. Fritidsrettede } \\
\text { aktiviteter }\end{array}$ & 13 & 17 & 40 & 31 \\
\hline $\begin{array}{l}\text { Læser højt for bebo- } \\
\text { erne }\end{array}$ & 37 & 36 & 18 & 9 \\
\hline $\begin{array}{l}\text { Ser TV sammen med } \\
\text { beboerne }\end{array}$ & 5 & 17 & 43 & 34 \\
\hline $\begin{array}{l}\text { Spiller spil med be- } \\
\text { boerne (kort, me- } \\
\text { mory, o.l.) }\end{array}$ & 8 & 15 & 28 & 50 \\
\hline $\begin{array}{l}\text { Rytmik, bevægelse, } \\
\text { gymnastik, lege }\end{array}$ & 11 & 17 & 38 & 35 \\
\hline Musik, fællessang & 1 & 10 & 32 & 57 \\
\hline Tegning, maling & 3 & 7 & 32 & 58 \\
\hline $\begin{array}{l}\text { Andre aktiviteter, } \\
\text { f.eks. sy, arbejde } \\
\text { med perler, træ o.I. }\end{array}$ & 0 & 2 & 63 & 34 \\
\hline $\begin{array}{l}\text { Udeaktiviteter, gåtu- } \\
\text { re, køreture o.l. }\end{array}$ & 34 & 0 & 67 & 33 \\
\hline $\begin{array}{l}\text { Biograf, teater og } \\
\text { lign. }\end{array}$ & 0 & & & \\
\hline $\begin{array}{l}\text { Rejser med overnat- } \\
\text { ning }\end{array}$ & 0 & & & \\
\hline
\end{tabular}

Svarfordelingerne på skalaen mellem flere gange dagligt og mindre end en gang om ugen eller aldrig er her stort set modsat dem, der karakteriserer omsorgsrettede og praktiske aktiviteter.

Kun på to delspørgsmål - at se TV sammen med beboerne og være på gåture o.I. er der over en tredjedel af medarbejderne, der markerer det som en daglig aktivitet, og på næsten alle delspørgsmål er andelen, der svarer 'mindre end en gang ugentligt' 
eller aldrig højere end to tredjedele af samtlige svar, med tendens til en lille overvægt af pædagoger, der svarer mindre end en gang ugentligt mod en tilsvarende overvægt af omsorgsmedhjælpere, der her markerer 'aldrig' eller 'har ikke denne aktivitet'.

Den relativt lave aktivitetsgrad i forhold til en 'aktiv' fritid sammen med beboerne, må vurderes i forhold til, at en del af de mere kreative aktiviteter, der er spurgt ind til, er aktivitetstyper, en del beboere er beskæftiget med i dagtilbuddene, f.eks. maling, syning, musik og rytmik, eller udtrykt på en anden måde: Aktiviteter, der i andre sammenhænge betragtes som fritidsaktiviteter i modsætning til arbejdsaktiviteter, må for en del beboeres vedkommende snarere betegnes som arbejdsaktiviteter, der naturligt nok ikke betragtes som vigtige også at beskæftige sig med i fritiden på bostedet.

\section{Oplevelse af vanskelige omsorgsopgaver i det daglige arbej- de?}

En sidste type spørgsmål skal medtages i forbindelse med karakteristikken af det daglige arbejde på bo- og dagtilbuddene, nemlig om der er særlige arbejdsopgaver i forhold til beboerne/brugerne, der opleves vanskelige.

Ses der efter andelen af medarbejdere, der 'slet ikke' oplever de daglige omsorgsopgaver som vanskelige, er det lidt over en tredjedel (39\%), der svarer således ifm. den praktiske omsorg, en femtedel (21 \%) ift. at opleve at kunne 'ramme' passende stimulering og udfordringer for den enkelte beboer, og knap en femtedel (17 \%) i forhold til at kunne respondere på, hvad beboerne selv udtrykker af ønsker om udfordrende aktiviteter.

Den samlede svarfordeling på de tre spørgsmål er:

Tabel 17. Oplevelse af at arbejdet som vanskeligt i forhold til følgende områder

\begin{tabular}{|l|c|c|c|c|}
\hline $\begin{array}{l}\text { I hvilken grad opleves arbej- } \\
\text { det vanskeligt i forhold til føl- } \\
\text { gende områder }\end{array}$ & $\begin{array}{c}\text { I høj } \\
\text { grad } \\
\text { vanske- } \\
\text { ligt } \\
\text { Alle i \% }\end{array}$ & $\begin{array}{c}\text { I nogen } \\
\text { grad } \\
\text { vanske- } \\
\text { ligt } \\
\text { Alle i } \%\end{array}$ & $\begin{array}{c}\text { I mindre } \\
\text { grad } \\
\text { vanske- } \\
\text { ligt } \\
\text { Alle i \% }\end{array}$ & $\begin{array}{c}\text { Slet ikke } \\
\text { vanske- } \\
\text { ligt }\end{array}$ \\
Alle i \% \\
\hline $\begin{array}{l}\text { Den praktiske omsorg for beboe- } \\
\text { re/brugere }\end{array}$ & 3 & 29 & 30 & 39 \\
\hline $\begin{array}{l}\text { Omsorg i forhold til dine forvent- } \\
\text { ninger til passende stimule- } \\
\text { ring/udfordring }\end{array}$ & 10 & 35 & 34 & 21 \\
\hline $\begin{array}{l}\text { Omsorg i forhold til hvad beboer- } \\
\text { ne/brugerne selv ønsker af udfor- } \\
\text { dringer }\end{array}$ & 11 & 40 & 32 & 17 \\
\hline
\end{tabular}

I den modsatte ende af skalaen, er det de færreste medarbejdere (mellem 3\% og 11 $\%)$, der oplever de nævnte omsorgsdimensioner som 'i høj grad vanskelige' at indfri, men deles op i en slags +/- opdeling, er der trods alt en tredjedel (32\%), der sætter kryds ved at de oplever den daglige praktiske omsorg som 'i høj' eller 'nogen grad' 
vanskelig, mens mere end halvdelen (51 \%) i høj eller nogen grad oplever omsorgsopgaven i forhold til, hvad beboeren/brugerens selv ønsker af udfordringer, vanskelig.

Ses der efter forskellige svarmønstre mellem pædagogerne og omsorgsmedhjælperne, er der ikke - som på spørgsmålet om medansvar - markante forskelle mellem pædagogerne og omsorgsmedhjælperne, og tendensen er, at mens der på delspørgsmål tre stort set ikke er forskelle i andelene, der svarer 'i høj grad' eller 'slet ikke', er det lidt flere omsorgsmedhjælpere end pædagoger, der 'slet ikke' finder det vanskeligt ift. delspørgsmålene et og to, mod modsat lidt flere pædagoger, som her svarer 'i høj grad'. $^{56}$

En anden side af oplevelsen af 'vanskelige opgaver' er, om man som medarbejder i det daglige arbejde oplever en fortrolighed eller får indsigt i nogle problemer, beboeren vurderes at stå med, uden at man som pædagogisk udøvende umiddelbart ved, hvad man skal stille op med denne viden om 'den anden'.

Tabel 18 vedrører to delspørgsmål af denne type:

Tabel 18. 'Vanskelig viden' om beboere/brugere, du er tilknyttet

\begin{tabular}{|c|c|c|c|c|}
\hline $\begin{array}{l}\text { 'Vanskelig viden' om } \\
\text { beboere/ brugere, du er til- } \\
\text { knyttet }\end{array}$ & $\begin{array}{l}\text { Ofte } \\
\text { Alle i \% }\end{array}$ & $\begin{array}{l}\text { En gang } \\
\text { imellem } \\
\text { Alle i \% }\end{array}$ & $\begin{array}{l}\text { Sjældent } \\
\text { Alle i \% }\end{array}$ & $\begin{array}{l}\text { Aldrig } \\
\text { Alle i \% }\end{array}$ \\
\hline $\begin{array}{l}\text { Hvor ofte oplever du at få indsigt i } \\
\text { beboere/brugeres forhold, som du } \\
\text { ikke ved hvad du skal stille op } \\
\text { med? }\end{array}$ & 6 & 35 & 50 & 8 \\
\hline $\begin{array}{l}\text { Hvor ofte oplever du problemer i } \\
\text { forhold til dine beboere/brugere, } \\
\text { som du ikke ved hvad du skal } \\
\text { stille op med? }\end{array}$ & 8 & 41 & 46 & 5 \\
\hline $\begin{array}{l}\text { * Hvis du har svaret bekræftende } \\
\text { til et af de to foregående spørgs- } \\
\text { mål, har du da givet denne viden } \\
\text { videre til din leder, men oplevet at } \\
\text { informationen ikke er blevet taget } \\
\text { tilstrækkeligt alvorligt? }\end{array}$ & 11 & 19 & 22 & 48 \\
\hline
\end{tabular}

Et fåtal medarbejdere (6-8 \%) markerer at de 'ofte' får indsigt eller indblik i 'vanskelig viden', enten om en beboers personlige forhold eller i forholdet til beboeren, som de ikke umiddelbart ved, hvad de skal stille op med for at forandre situationen, og i den anden ende af skalaen er det et tilsvarende lavt antal medarbejdere (5-8\%), der svarer 'aldrig'. Deles igen op i +/- sider er det dog $41 \%$, der svarer 'ofte' eller 'en gang imellem' på spørgsmålet om hvor ofte de 'oplever at få indsigt i beboere/brugeres forhold, som du ikke ved hvad du skal stille op med?', mens halvdelen (49\%) svarer således ift.

\footnotetext{
${ }^{56}$ Se bilag 3 for fordelingen.
} 
at opleve 'problemer i forhold til dine beboere/brugere, som du ikke ved hvad du skal stille op med?'

På tillægsspørgsmålet til denne gruppe, om de så oplever ikke at få lydhørhed, hvis problemstillingen forelægges afdelingsledere, svarer halvdelen (48 \%) 'aldrig', men der er en tredjedel (30\%) for hvem denne oplevelse ikke er ukendt, og som derfor svarer 'ofte' (11\%) eller 'en gang imellem' (19\%).

Spørgsmål om 'vanskelig viden' kunne være en type, hvor forskelle mellem uddannede pædagoger og ikke-pædagoguddannede omsorgsmedhjælpere kunne vise sig i kraft af de pædagoguddannedes (forventelige) højere teoretiske faglige beredskab, der kan gøres aktiv i vanskelige situationer, men her er der kun helt marginale forskelle mellem de to faggrupper (mellem 1 og 3 \%) på de to yderspørgsmål 'ofte' og 'aldrig'.

Hvorvidt andre situationer i det daglige arbejde opleves enten psykisk eller fysisk belastende for mange medarbejdere er temaet i næste kapitel, der handler om trivselsspørgsmål. 


\section{Kapitel 6}

\section{Trivsel på arbejdspladsen}

I undersøgelser som nærværende er medarbejdernes karakteristik af arbejdsmiljøet på deres arbejdssted som nævnt i kapitel to uomgængelige, og i kapitel 6 går vi lidt mere i dybden med medarbejdernes beskrivelser af trivslen ud fra henholdsvis det psykiske og det fysiske arbejdsmiljø.

\section{Det psykiske arbejdsmiljø}

I spørgsmål 21 indgår en række typiske spørgsmål omkring oplevelse af belastende psykiske arbejdsrelaterede faktorer ${ }^{57}$, som med afsæt i svarkategorien 'Slet ikke', kan inddeles i tre grupperinger; en hvor mere end halvdelen svarer således, en anden hvor omkring en tredjedel svarer 'slet ikke', og endelig en tredje gruppering, hvor en fjerdedel eller derunder 'slet ikke' oplever belastende psykiske faktorer.

Den første gruppering er:

Tabel 21. Belastende psykiske faktorer i arbejdet (uddrag) ${ }^{58}$

\begin{tabular}{|l|c|c|c|c|}
\hline $\begin{array}{l}\text { Belastende psykiske faktorer i } \\
\text { arbejdet }\end{array}$ & $\begin{array}{c}\text { Slet ikke } \\
\text { Antal i \% }\end{array}$ & $\begin{array}{c}\text { I mindre } \\
\text { grad } \\
\text { Antal i \% }\end{array}$ & $\begin{array}{c}\text { I nogen } \\
\text { grad } \\
\text { Antal i \% }\end{array}$ & $\begin{array}{c}\text { I høj } \\
\text { grad } \\
\text { Antal i \% }\end{array}$ \\
\hline Utryghed i ansættelse & 77 & 13 & 7 & 2 \\
\hline $\begin{array}{l}\text { Manglende anerkendelse fra anden } \\
\text { faggruppe }\end{array}$ & 58 & 24 & 13 & 4 \\
\hline $\begin{array}{l}\text { Manglende støtte og hjælp fra kolle- } \\
\text { ger i belastede situationer }\end{array}$ & 54 & 30 & 13 & 4 \\
\hline $\begin{array}{l}\text { At arbejdet ikke er tilstrækkelig inte- } \\
\text { ressant og spændende }\end{array}$ & 54 & 31 & 13 & 2 \\
\hline $\begin{array}{l}\text { Jeg er usikker på hvad der forventes } \\
\text { af mig }\end{array}$ & 51 & 34 & 13 & 1 \\
\hline
\end{tabular}

Den kategori, der scorer højest på 'slet ikke', er spørgsmålet om utryghed i ansættelsen, og generelt må andelen af medarbejdere, der svarer 'i nogen' eller 'i høj' grad belastende på spørgsmål om oplevelsen af manglende professionsfaglig anerkendelse, manglende støtte og hjælp fra kolleger, uinteressant arbejde eller usikkerhed omkring

\footnotetext{
${ }^{57}$ Udover dem, der nævnes i kapitlet her, rummer spørgsmål 21 yderligere 5 spørgsmål om oplevelse af psykiske belastninger i det direkte arbejde med beboerne. De er inddraget i kapitel tre, således at der i oversigten her kun er medtaget mere klassiske spørgsmål om oplevelsen af psykiske arbejdsmiljøbelastninger.

${ }^{58}$ I dette kapitel er svarkategorien 'Denne faktor ikke relevant for mig' neutraliseret i gennemgangen af nogle af tabellerne. Se bilag 3 for den mere detaljerede opdeling.
} 
forventninger til arbejdsindsatsen, vurderes som relativt lav - mellem 9 og 17 \% samlet.

Ledes der efter eventuelle forskelle i svarmønstre mellem pædagoggruppen og omsorgsmedhjælpergruppen er der kun to spørgsmål, hvor der kan iagttages relative store variationer i andelen, der svarer 'slet ikke'; nemlig ifm. 'manglende anerkendelse fra anden faggruppe', hvor $58 \%$ af pædagogerne mod $41 \%$ af omsorgsmedhjælperne svarer således, og ift. tryghed i ansættelsen, hvor $80 \%$ af pædagogerne mod $68 \%$ af omsorgsmedhjælperne her sætter kryds ved 'slet ikke'.

Den næste gruppering med tre spørgsmål fordeler svarmønstrene sig med omkring en tredjedel, der svarer 'slet ikke', en tredjedel, der vælger svarmuligheden 'i mindre grad' og endelig den sidste tredjedel med kryds i svarkategoriene 'i nogen' eller 'i høj' grad:

\begin{tabular}{|l|c|c|c|c|}
\hline $\begin{array}{l}\text { Belastende psykiske faktorer i } \\
\text { arbejdet }\end{array}$ & Slet ikke & $\begin{array}{c}\text { I mindre } \\
\text { grad } \\
\text { Antal i \% }\end{array}$ & $\begin{array}{c}\text { I nogen } \\
\text { grad } \\
\text { Antal i \% }\end{array}$ & $\begin{array}{c}\text { I høj } \\
\text { grad } \\
\text { Antal i \% }\end{array}$ \\
\hline $\begin{array}{l}\text { Manglende mulighed for personlig } \\
\text { udvikling i arbejdet }\end{array}$ & 35 & 34 & 24 & 7 \\
\hline Samarbejde i personalegruppen & 33 & 36 & 17 & 13 \\
\hline Manglende fælles mål i arbejdet & 32 & 35 & 24 & 9 \\
\hline
\end{tabular}

De tre spørgsmål i midtergruppen med fokus på manglende mulighed for personlig udvikling, problemer i samarbejdet og oplevelsen af manglende fælles mål i arbejdet, har praktisk talt identiske svarfordelinger mellem omsorgsmedhjælpere og pædagoger.

Det gør sig derimod ikke gældende under alle delspørgsmål i den tredje gruppering der hvor belastende psykiske faktorer i arbejdet generelt vurderes højest. Her er andelen af omsorgsmedhjælpere, der 'slet ikke' oplever belastning en del større end for pædagoger på spørgsmålet omkring 'Mængden af arbejdsopgaver pr. dag' (her svarer $26 \%$ af omsorgsmedhjælperne således mod $11 \%$ af pædagogerne) og ifm. 'Vigtige beslutninger under tidspres' (hvor fordelingen er $26 \%$ mod $16 \%$ ).

Under andre spørgsmål som 'Stort ansvar' og 'Egne høje krav til arbejdspræstation' er der ingen større forskelle i svarmønstrene de to faggrupper imellem. 


\begin{tabular}{|l|c|c|c|c|}
\hline $\begin{array}{l}\text { Belastende psykiske faktorer i } \\
\text { arbejdet }\end{array}$ & Slet ikke & $\begin{array}{c}\text { I mindre } \\
\text { grad } \\
\text { Antal i \% }\end{array}$ & $\begin{array}{c}\text { I nogen } \\
\text { grad } \\
\text { Antal i \% }\end{array}$ & $\begin{array}{c}\text { I høj } \\
\text { grad } \\
\text { Antal i \% }\end{array}$ \\
\hline Modstridende krav i arbejdet & 26 & 36 & 25 & 12 \\
\hline Stort ansvar & 25 & 30 & 23 & 22 \\
\hline Egne høje krav til arbejdspræstation & 19 & 24 & 32 & 24 \\
\hline Vigtige beslutninger under tidspres & 19 & 39 & 31 & 11 \\
\hline Mængden af arbejdsopgaver pr. dag & 15 & 30 & 37 & 18 \\
\hline
\end{tabular}

Den tredje gruppering er som nævnt den, hvor færrest markerer 'Slet ikke' belastende, og hermed er der også en større andel i enden af oplevede psykiske belastninger, og samlet er der to spørgsmål, hvor over halvdelen af medarbejderne 'i høj grad' eller 'i nogen grad' oplever belastende psykiske faktorer i arbejdet; nemlig ' Mængden af arbejdsopgaver pr. dag' (55\%), 'Egne høje krav til arbejdspræstation' (56\%).

Disse to belastningsfaktorer er 'typisk' stress-relateret på hver sin måde, idet der såvel opleves for mange 'ydre' krav til arbejdsindsats som 'indre' krav til egne præstationer.

Det samlede billede af oplevelsen af arbejdsmiljøet som mere eller mindre psykisk belastende er - som også nævnt i kapitel $2^{59}$ - at omkring hver fjerde medarbejder oplever arbejdsmiljøet som noget eller meget psykisk belastende, mens hovedparten sætter kryds ved 'lidt psykisk belastende' og omkring en syvendedel mener ikke arbejdsmiljøet er psykisk belastende, med en overvægt af omsorgsmedhjælpere i sidstnævnte kategori.

I tabelform er fordelingen:

Tabel 20. Oplevelse af det psykiske arbejdsmiljø som helhed.

\begin{tabular}{|l|c|c|c|}
\hline $\begin{array}{l}\text { Oplever du alt i alt at dit arbejde } \\
\text { er psykisk belastende? }\end{array}$ & $\begin{array}{c}\text { Nej, ikke } \\
\text { psykisk bela- } \\
\text { stende } \\
\text { Antal i \% }\end{array}$ & $\begin{array}{c}\text { Lidt psykisk } \\
\text { belastende }\end{array}$ & $\begin{array}{c}\text { Noget eller } \\
\text { meget } \\
\text { psykisk bela- } \\
\text { stende } \\
\text { Antal i \% }\end{array}$ \\
\hline Alle & 14 & 59 & 27 \\
\hline Pædagoger & 11 & 61 & 28 \\
\hline Omsorgsmedhjælpere & 20 & 56 & 24 \\
\hline
\end{tabular}

\footnotetext{
${ }^{59}$ Da kapitel 2 præsenterede nogle overordnede 'konklusioner' er der lidt gentagne opgørelser i de mere detaljerede gennemgange af trivsel (kapitel 6) og personprofiler (kapitel 7).
} 


\section{Det fysiske arbejdsmiljø}

Vendes blikket mod det lidt mere håndgribelige fysiske arbejdsmiljø er der 11 delspørgsmål herom med svarmuligheden 'ja', 'nej' og 'ved ikke' i forhold til oplevede gener. De 11 delspørgsmål kan deles op i to næsten lige store grupperinger. En hvor et flertal svarer 'ja' til 'i generende grad', og en hvor et flertal svarer 'nej' hertil.

Grupperingen med overvægt af 'ja-svar' består af følgende spørgsmål:

Tabel 23. Forekommer nogle af de nedenstående faktorer i generende grad i dit arbejde

\begin{tabular}{|l|c|c|c|}
\hline $\begin{array}{l}\text { Forekommer nogle af de neden- } \\
\text { stående faktorer i generende } \\
\text { grad i dit arbejde? }\end{array}$ & $\begin{array}{c}\text { Ja } \\
\text { Antal i \% }\end{array}$ & $\begin{array}{c}\text { Nej } \\
\text { Antal i \% }\end{array}$ & $\begin{array}{c}\text { Ved ikke } \\
\text { Antal i \% }\end{array}$ \\
\hline Forstyrrende lyde, megen støj & 61 & 36 & 3 \\
\hline $\begin{array}{l}\text { Tunge løft eller andre belastende } \\
\text { arbejdsstillinger eller bevægelser }\end{array}$ & 60 & 38 & 2 \\
\hline For små arbejdslokaler & 60 & 38 & 2 \\
\hline For mange personer i samme rum & 55 & 40 & 5 \\
\hline Dårlig ventilation & 51 & 43 & 6 \\
\hline
\end{tabular}

Støj, belastende fysiske bevægelser og for små lokaler er de tre fysiske faktorer, som opleves mest generende i det daglige arbejdsmiljø, og generelt for ovenstående delspørgsmål som de, der følger i næste tabel gælder, at andelen af pædagoger, der svarer 'ja' til fysisk belastende arbejdsmiljø er lidt større end blandt omsorgsmedhjælperne, bortset fra under to spørgsmål, hvor andel af 'ja-svarere' er størst blandt omsorgsmedhjælpere, nemlig omkring 'Tunge løft eller andre belastende arbejdsstillinger eller bevægelser' og 'Mangelfuld rengøring' (hvor forskellen dog er minimal).

Den anden gruppering af delspørgsmål, hvor der er et flertal, der svarer 'nej' til generende fysisk faktorer, er: 


\begin{tabular}{|l|c|c|c|}
\hline $\begin{array}{l}\text { Forekommer nogle af de neden- } \\
\text { stående faktorer i generende } \\
\text { grad i dit arbejde? }\end{array}$ & $\begin{array}{c}\text { Ja } \\
\text { Antal i \% }\end{array}$ & Antal i \% & Antal i \% \\
\hline Træk i lokalet & 30 & 62 & 8 \\
\hline Mangelfuld rengøring & 40 & 56 & 3 \\
\hline For ringe sanitære forhold & 40 & 55 & 5 \\
\hline Ingen eller for få personalerum & 45 & 52 & 2 \\
\hline Temperaturforhold (varme/kulde) & 41 & 52 & 6 \\
\hline Tør luft & 36 & 51 & 12 \\
\hline
\end{tabular}

Det samlede indtryk af fysisk belastende faktorer i dagligdagen er - som under de psykisk belastende faktorer - at omkring en fjerdedel oplever det fysiske arbejdsmiljø som 'Noget eller meget fysisk belastende', jf. tabel 22:

Tabel 22. Oplevelse af det fysiske arbejdsmiljø som helhed

\begin{tabular}{|l|c|c|c|}
\hline $\begin{array}{l}\text { Oplever du alt i alt at dit arbejde } \\
\text { er fysisk belastende? }\end{array}$ & $\begin{array}{c}\text { Nej, ikke } \\
\text { fysisk } \\
\text { belastende } \\
\text { Antal i \% }\end{array}$ & $\begin{array}{c}\text { Lidt fysisk } \\
\text { belastende }\end{array}$ & $\begin{array}{c}\text { Noget eller } \\
\text { meget fy- } \\
\text { sisk bela- } \\
\text { stende } \\
\text { Antal i \% }\end{array}$ \\
\hline Alle & 35 & 40 & 25 \\
\hline Pædagoger & 35 & 41 & 24 \\
\hline Omsorgsmedhælpere & 33 & 37 & 30 \\
\hline
\end{tabular}

Her er der - igen sammenlignet med svarmønstre i forhold til psykisk arbejdsmiljø - en noget større andel, der ikke oplever generende fysiske belastninger, idet omkring en tredjedel har sat deres kryds ved denne mulighed.

\section{Trivsel, men også ønske om forandring i arbejdet}

Det samlede indtryk er sammenfattet under tabel 24 , hvor der spørges til tilfredshedsniveau frem for belastningsniveau. Her er et klart flertal 'i høj' eller 'i nogen grad' alt i alt tilfredse med arbejdsbetingelserne (der også indbefatter andet end direkte psykiske og fysiske belastningsfaktorer), mens mindre end hver femte medarbejder udtrykker mere eller mindre utilfredshed, som det fremgår af følgende tabel: 
Tabel 24. Er du alt i alt tilfreds med dit nuværende arbejde (uddrag)?

\begin{tabular}{|l|c|c|c|c|}
\hline $\begin{array}{l}\text { Er du alt i alt tilfreds med } \\
\text { dit nuværende arbejde } \\
\text { mht. arbejdsbetingelser- } \\
\text { ne? }\end{array}$ & $\begin{array}{c}\text { Ja, i høj } \\
\text { grad }\end{array}$ & $\begin{array}{c}\text { Ja, i nogen } \\
\text { grad } \\
\text { Antal i \% }\end{array}$ & $\begin{array}{c}\text { Nej, } \\
\text { kun i min- } \\
\text { dre grad } \\
\text { Antal i \% }\end{array}$ & $\begin{array}{c}\text { Nej, slet } \\
\text { I kke } \\
\text { Antal i \% }\end{array}$ \\
\hline Alle & 36 & 46 & 16 & 2 \\
\hline Pædagoger & 36 & 45 & 17 & 2 \\
\hline Omsorgsmedhjælpere & 36 & 48 & 14 & 2 \\
\hline
\end{tabular}

Krydses dette svarmønster med et andet spørgsmål om, hvorvidt de deltagende pædagoger og omsorgsmedhjælpere inden for det seneste år har overvejet at skifte job, er det umiddelbare indtryk af tilfredshed med det aktuelle arbejde lidt anderledes, idet et flertal blandt såvel pædagoger som omsorgsmedhjælpere svarer bekræftende på, at det har de overvejet:

Tabel 34. Ønske om personlig forandring i jobbet?

\begin{tabular}{|l|c|c|}
\hline $\begin{array}{l}\text { Har du inden for det seneste år } \\
\text { overvejet at finde et andet arbejde } \\
\text { eller søge en uddannelse? }\end{array}$ & $\begin{array}{c}\text { Ja } \\
\text { Antal i \% }\end{array}$ & $\begin{array}{c}\text { Nej } \\
\text { Antal i \% }\end{array}$ \\
\hline Pædagoger & 55 & 45 \\
\hline Omsorgsmedhjælpere & 64 & 36 \\
\hline
\end{tabular}

Her skal dog medtænkes, at det så at sige er 'gratis' at overveje, om der skulle være andre og mere attraktive jobmuligheder, men på grund af det supplerende spørgsmål til spørgsmål 34 - hvad vigtigste grunde til at overveje jobskifte i så fald er - giver svarene herpå et fingerpeg omkring hvad som først og fremmest kan være individuelle grunde til eventuelt aktivt at søge nye græsgange.

Deles her på ny op i to grupperinger - denne gang med begrundelser direkte relateret til det nuværende arbejde, og mere generelle begrundelser - er det omkring halvdelen af svarene, der kan relateres konkret til det nuværende arbejde, og her er det arbejdsklima, arbejdstider, arbejdsmæssige belastninger og oplevelsen af manglende anerkendelse, der dominerer, om end der er tale om relativt små procenttal under hver kategori: 
Tabel 34A. Hvis 'ja' til du har overvejet at finde et andet arbejde eller søge uddannelse. Hvad er da de 2 vigtigste grunde hertil?

\begin{tabular}{|l|c|}
\hline $\begin{array}{l}\text { De to vigtigste grunde til at over- } \\
\text { veje andet arbejde eller søge en } \\
\text { uddannelse }\end{array}$ & Alle \\
\hline $\begin{array}{l}\text { Pga. for mange konflikter og dårligt } \\
\text { arbejdsklima på arbejdspladsen }\end{array}$ & 10 \\
\hline For at få bedre arbejdstider & 9 \\
\hline Fordi arbejdet er for anstrengende & 8 \\
\hline $\begin{array}{l}\text { Fordi jeg oplever for lidt arbejdsmæs- } \\
\text { sig anerkendelse i offentligheden }\end{array}$ & 8 \\
\hline $\begin{array}{l}\text { Fordi jeg oplever for lidt arbejdsmæs- } \\
\text { sig anerkendelse internt }\end{array}$ & 4 \\
\hline Fordi arbejdet er for kedeligt & 4 \\
\hline Af hensyn til helbredet & 1 \\
\hline Manglende tryghed i ansættelsen & $52 \%$ \\
\hline SAMLET & \\
\hline
\end{tabular}

\begin{tabular}{|l|c|}
\hline $\begin{array}{l}\text { De to vigtigste grunde til at over- } \\
\text { veje andet arbejde eller søge en } \\
\text { uddannelse }\end{array}$ & Alle \\
\hline $\begin{array}{l}\emptyset \text { Ønske om nye udfordringer eller prøve } \\
\text { noget nyt }\end{array}$ & 28 \\
\hline For at påbegynde anden uddannelse. & 6 \\
\hline Andet: (skriv evt. hvad) $*$ & 5 \\
\hline Af hensyn til familien & 4 \\
\hline $\begin{array}{l}\text { For at påbegynde pædagoguddannel- } \\
\text { sen }\end{array}$ & 3 \\
\hline For at færdiggøre uddannelse & 2 \\
\hline $\begin{array}{l}\text { For at påbegynde Pædagogisk Assi- } \\
\text { stent Uddannelse (tidligere PGU) }\end{array}$ & 0 \\
\hline SAMLET & $48 \%$ \\
\hline
\end{tabular}

Tilkendegivelser fra hovedparten af såvel pædagoger som omsorgsmedhjælpere omkring en relativ $h \varnothing j$ grad af tilfredshed med det nuværende arbejdsmiljø, og overvejelser om at prøve noget andet, få bedre arbejdstider og et andet arbejdsklima er optakten til næste kapitel, hvor der følges op på personprofilerne fra kapitel 2 med lidt mere detaljerede beskrivelser af medarbejdernes arbejdsfunktioner, arbejdstider, uddannelsesbaggrund mv. 


\section{Kapitel 7}

\section{Arbejdsvilkår, kompetenceudvikling og med- arbejdernes uddannelses- og erfaringsbag- grund}

På de følgende sider tages tråden op fra kapitel 2's introducerende beskrivelse af medarbejdernes køns- og aldersfordeling, arbejdstider, anciennitet, mv.

Efter en gennemgang af arbejdstider og ansættelsesform, følger beskrivelsen af i hvilket omfang, medarbejdernes tilbydes interne eller eksterne faglige kurser. Herefter er fokus på deres uddannelsesbaggrund, herunder om der er mange medarbejdere, der har andre uddannelser bag sig end en pædagog- eller PGU-uddannelse, og hvad der karakteriserer deres arbejdsmæssige erfaringsbaggrund, hvor en del har været ansat inden for andre arbejdsområder forud for nuværende arbejde i bo- og dagtilbud. Endelig sluttes af med en kort beskrivelse af de deltagende pædagoger og omsorgsmedhjælperes fremtidsforventninger i erhvervsmæssig henseende - om de ser sig selv på vej andre steder hen.

Kapitlet er således præget af en række faktuelle oplysninger, hvorfor der ikke vil være så megen beskrivende og analyserende tekst mellem de statistiske oversigter.

Det kommer der til gengæld på ny i det afsluttende kapitel 8.

\section{Ansættelsesgrad og arbejdsvilkår}

Som det fremgår af tabel 12 er langt hovedparten af pædagogerne fuldtidsansat (80 $\%)$, mens det samme gælder for omkring halvdelen af omsorgsmedhjælperne (54\%), og ses der på den samlede andel, der arbejder mere end 31 timer ugentligt, er det 86 $\%$.

Tabel 12. Ugentlig arbejdstid

\begin{tabular}{|l|c|c|c|}
\hline Ugentlig arbejdstid & $\begin{array}{c}\text { Pædagoger } \\
\text { i \% }\end{array}$ & $\begin{array}{c}\text { Omsorgs- } \\
\text { medhjælpere } \\
\mathbf{i} \%\end{array}$ & $\begin{array}{c}\text { Alle } \\
\mathbf{i} \%\end{array}$ \\
\hline Op til 19 timer & 1 & 15 & 4 \\
\hline Mellem 20 og 27 timer & 3 & 5 & 4 \\
\hline Mellem 28 og 31 timer & 5 & 7 & 6 \\
\hline Mellem 32 og 36 timer & 11 & 20 & 13 \\
\hline 37 timer eller mere (fuld tid) & 80 & 54 & 73 \\
\hline
\end{tabular}

At der trods alt er en del - især omsorgsmedhjælpere - der ikke er fuldtidsansatte (heraf $15 \%$ af omsorgsmedhjælperne med under 20 ugentlige timer), afspejles ikke i utilfredshed med ansættelsesgraden. Kun $5 \%$ af omsorgsmedhjælpere og $9 \%$ af pæ- 
dagogerne tilkendegiver, at de ikke er tilfredse med deres aktuelle ansættelsesgrad, og vigtigt er her at bemærke, at de fleste af de 'ikke tilfredse' vil foretrække et lavere antal ugentlige arbejdstimer. I faktiske tal er det kun 2 omsorgsmedhjælpere ud af de 245 deltagende i undersøgelsen, der markerer $\emptyset$ nske om en $\varnothing$ get ansættelsesgrad ${ }^{60}$.

Et andet spørgsmål vedrørende arbejdsvilkår er om der er tale om faste eller varierende arbejdstider, enten i løbet af dagen, ugen eller fra måned til måned.

Her viser det sig - ikke overraskende - at langt hovedparten af medarbejderne har skiftende arbejdstider, som det fremgår af tabel 14:

Tabel 14. Varierende arbejdstid

\begin{tabular}{|l|c|c|c|}
\hline Varierende arbejdstid & $\begin{array}{c}\text { Pædagoger } \\
\mathbf{i} \%\end{array}$ & $\begin{array}{c}\text { Omsorgs- } \\
\text { medhjælpere } \\
\mathbf{i} \%\end{array}$ & $\begin{array}{c}\text { Alle } \\
\mathbf{i} \%\end{array}$ \\
\hline $\mathrm{Ja}$ & 95 & 85 & 92 \\
\hline $\mathrm{Nej}$ & 5 & 15 & 8 \\
\hline
\end{tabular}

Samlet har mere end ni ud af ti ansatte varierende arbejdstider. Flest pædagoger (95 $\%)$, og blandt omsorgsmedhjælperne er det en syvendedel, $15 \%$, der har faste arbejdstider, og det er formentlig her, de i faktiske tal 10 omsorgsmedhjælpere, der markerer, at de har fast nattevagt, skal findes ${ }^{61}$.

Et underspørgsmål i forbindelse med varierende arbejdstider er, om det er ugentligt eller sjældnere? Langt hovedparten af de medarbejdere, der har svaret 'ja' til varierende arbejdstider, har samtidigt sat kryds ved, at de forekommer ugentligt. Det drejer sig om $96 \%$ af pædagogerne og $87 \%$ af omsorgsmedhjælperne, og det er således et fåtal, der 'kun' har varierende arbejdstider fra uge til uge eller måned til måned ${ }^{62}$.

I faktiske antal svarer 8 pædagoger og 12 omsorgsmedhjælpere, at de har fast afteneller natarbejde. Tilsvarende er medarbejdere med 'varierende arbejdstid' spurgt ind til, om variationerne indbefatter aften- eller natarbejde?

Her er svarmønstrene:

\footnotetext{
${ }^{60}$ Bilag 3, tabel 13.

${ }^{61}$ Se bilag 3, tabel 14.A 1 og 14.A2.

62 Bilag 3, tabel 14B.
} 
Tabel 14D. Om aften eller natarbejde forekommer

\begin{tabular}{|l|c|c|c|}
\hline $\begin{array}{l}\text { Hvis 'ja' til varierende ar- } \\
\text { bejdstider, forekommer da } \\
\text { aften eller natarbejde? }\end{array}$ & Pædagoger & $\begin{array}{c}\text { Omsorgs- } \\
\text { medhjælpere } \\
\mathbf{i} \%\end{array}$ & Alle \\
\hline Ja til at aftenarbejde forekommer & 94 & 93 & 94 \\
\hline $\begin{array}{l}\text { Nej til at aftenarbejde forekom- } \\
\text { mer }\end{array}$ & 6 & 7 & 6 \\
\hline & & & \\
\hline Ja til at natarbejde forekommer & 25 & 45 & 30 \\
\hline Nej til at natarbejde forekommer & 75 & 55 & 70 \\
\hline
\end{tabular}

Svarmønstrene i tabel 14D viser, at aftenarbejde er forekommende som en del af arbejdsplanen for langt de fleste medarbejdere med varierende arbejdstider. Samlet gælder det for $94 \%$ af dem, og det er lige hyppigt for omsorgsmedhjælpere og pædagoger, mens forskellen mellem de to medarbejdergrupper viser sig under delspørgsmålet om periodisk natarbejde.

Her er det en fjerdedel af pædagogerne ( $25 \%$ ) der svarer 'ja' til at natarbejde forekommer mod op mod halvdelen (45 \%) af omsorgsmedhjælperne, og samlet er det 30 $\%$ af medarbejdere med varierende arbejdstider, der svarer 'ja' til at natarbejde forekommer.

Et sidste spørgsmål skal med i kortlægningen af den del af arbejdsvilkårene, der angår varierende arbejdstider; nemlig om variationen kan være i løbet af dagen, f.eks. at møde frem til morgenvækning og så igen hen på eftermiddagen, når beboerne kommer hjem fra aktiviteter i dagtilbuddene?

Tabel 14C. Flere arbejdsintervaller i løbet af dagen?

\begin{tabular}{|c|c|c|c|}
\hline $\begin{array}{c}\text { Hvis 'ja' til varierende ar- } \\
\text { bejdstider, forekommer da } \\
\text { flere arbejdsintervaller om } \\
\text { dagen? }\end{array}$ & Pædagoger & $\begin{array}{c}\text { Omsorgs- } \\
\text { medhjælpere }\end{array}$ & Alle \\
\hline Ja & 11 & 18 & 13 \\
\hline Nej & 89 & 82 & 87 \\
\hline
\end{tabular}

Det er sjældent, at flere arbejdsintervaller i løbet af én dag forekommer, idet samlet 87 $\%$ af medarbejdere med varierende arbejdstider svarer 'nej' hertil, men det må tilføjes, at det er et umiddelbart overraskende stort mindretal - $11 \%$ pædagoger og $18 \%$ omsorgsmedhjælpere, der svarer 'ja' til at denne form for opbrudt arbejdsdag kan forekomme. Hvor ofte er dog et ubesvaret spørgsmål, da der ikke var mulighed for at tilkendegive det under udfyldelsen af spørgeskemaet. 


\section{I ntern og ekstern kompetenceudvikling}

Næste gruppe spørgsmål handler om i hvilken grad, medarbejderne har mulighed for at deltage i kortere eller længerevarende faglige kompetenceudviklende kursusdage eller kursusforløb enten internt i botilbuddet eller via deltagelse i kurser mv. uden for matriklen.

Først det generelle spørgsmål; nemlig hvorvidt faglige kurser og efteruddannelse overhovedet er blevet udbudt som mulighed og hvor medarbejderen har deltaget?

Her er svarmønstrene:

Tabel 31. Kurser/efteruddannelse inden for det pædagogiske område

\begin{tabular}{|l|c|c|}
\hline $\begin{array}{l}\text { Har du deltaget i kur- } \\
\text { ser/ efteruddannelse inden for det } \\
\text { pædagogiske område? }\end{array}$ & Ja & Nej \\
\hline Alle & Antal i \% & Antal i \% \\
\hline Pædagoger & 75 & 25 \\
\hline Omsorgsmedhjælpere & 82 & 18 \\
\hline
\end{tabular}

Samlet svarer tre ud af fire medarbejdere 'ja' til at have deltaget i kurser eller efteruddannelse inden for det pædagogiske område. Her er der stor forskel i svarmønstrene mellem pædagoger og omsorgsmedhjælpere, idet langt flere pædagoger (82\%) end omsorgsmedhjælpere (56 \%) svarer 'ja', og det er således kun lidt over halvdelen af omsorgsmedhjælperne, der markerer at de har deltaget i faglige kompetenceudviklingskurser eller efteruddannelsesaktiviteter.

En række delspørgsmål om hvorvidt det er interne eller eksterne kurser, antal, længde mv. giver et lidt mere indgående indtryk af, hvilket volumen formaliserede faglige kompetenceudviklingsinitiativer har.

\section{Interne kurser}

Først interne kurser, hvor halvdelen af medarbejderne (51 \%) sætter kryds ved, at de har deltaget heri: 
Tabel 31A. Hvis 'ja' til kurser/efteruddannelse på det pædagogiske område, da hvilke? (uddrag)

\begin{tabular}{|c|c|c|c|}
\hline I nterne kurser: & $\begin{array}{c}\text { Ja } \\
\text { Antal af alle } \\
\text { deltagende } \\
\text { medarbejdere i } \\
\%\end{array}$ & $\begin{array}{c}\text { Ja } \\
\text { Antal af alle } \\
\text { deltagende } \\
\text { pædagoger i } \\
\%\end{array}$ & $\begin{array}{c}\text { Ja } \\
\text { Antal af alle } \\
\text { deltagende } \\
\text { omsorgsmed- } \\
\text { hjælpere i \% }\end{array}$ \\
\hline Faglige kurser & 51 & 59 & 30 \\
\hline $\begin{array}{l}\text { Organisatorisk/ samar- } \\
\text { bejde/ arbejdsmiljø eller } \\
\text { lignende kursus }\end{array}$ & 41 & 44 & 30 \\
\hline $\begin{array}{l}\text { Andre interne kurser, da } \\
\text { hvilke: * }\end{array}$ & 28 & 29 & 17 \\
\hline
\end{tabular}

* Blandt 'Andre interne kurser' nævnes medicingivning, hygiejne, PC, samarbejde, kommunikation, forflytninger, værdigrundlag, førstehjælp, neuropædagogik, konfliktløsning, teamarbejde, praktikvejlederuddannelse

Blandt de interne kurser er der flest pædagoger, der har deltaget i faglige kurser. Lidt færre har deltaget i kurser omkring samarbejde, arbejdsmiljø mm. Endelig er der en del der har deltaget $\mathrm{i}$ andre interne kurser. Antallet af omsorgsmedhjælpere der har deltaget $\mathrm{i}$ interne kurser er lavere end for pædagogerne, og for alle tre typer kurser er det under en tredjedel af omsorgsmedhjælperne, der har deltaget.

Ses der på antallet af kurser inden for det sidste år, tegner der sig følgende billede af det typiske antal kurser og volumen målt i antal timer:

Tabel 31B. (uddrag). Hvor mange interne kurser har du haft på det pædagogiske område inden for det sidste år, og hvad er (cirka) det samlede antal kursustimer?

\begin{tabular}{|l|c|c|}
\hline Antal interne kurser. & $\begin{array}{c}\text { Antal pædagoger } \\
\text { i \% }\end{array}$ & $\begin{array}{c}\text { Antal omsorgsmedhjælpe- } \\
\text { re } i \text { \% }\end{array}$ \\
\hline 1 & 50 & 55 \\
\hline 2 & 29 & 18 \\
\hline 3 eller flere & 21 & 27 \\
\hline
\end{tabular}

\begin{tabular}{|l|c|c|}
\hline $\begin{array}{l}\text { Antal timer i alt på in- } \\
\text { terne kurser }\end{array}$ & $\begin{array}{c}\text { Antal pædagoger } \\
\mathrm{i} \%\end{array}$ & $\begin{array}{c}\text { Antal omsorgsmedhjælpe- } \\
\text { re } \mathrm{i} \%\end{array}$ \\
\hline Op til 16 timer & 52 & 67 \\
\hline $17-32$ timer & 22 & 0 \\
\hline $33-64$ timer & 14 & 33 \\
\hline Over 64 timer & 12 & 0 \\
\hline
\end{tabular}

Et enkelt kursus og under 16 timers kursusvirksomhed inden for det sidste år er det hyppigste såvel blandt pædagoger som omsorgsmedhjælpere, men der er dog omkring 
en fjerdedel, der har været på 3 eller flere kurser i årets løb med samlet mere end 33 timers kursusvirksomhed, men her skal tages højde for, at det ikke er procenttal, der gælder de samlede medarbejdergrupper; kun den andel - jf. tabel 31 ovenfor - der markerer at de har været på internt kursus.

\section{Eksterne kurser og efteruddannelse}

Spørges ind til deltagelse i eksterne kurser/efteruddannelse generelt (altså ikke nødvendigvis inden for det seneste år), er det de færreste, der har deltaget i eksempelvis 3 ugers AMU-kurser (samlet $9 \%$ ), og det hyppigste med omkring en tredjedel medarbejdere (35\%), heraf flest pædagoger, er kortere kurser 'uden for huset'.

Tabel 31A. Hvis 'ja' til kurser/efteruddannelse på det pædagogiske område, da hvilke? (uddrag)

\begin{tabular}{|c|c|c|c|}
\hline Eksterne kurser: & $\begin{array}{c}\text { Ja } \\
\text { Antal af alle } \\
\text { deltagende } \\
\text { medarbejdere i } \\
\%\end{array}$ & $\begin{array}{c}\text { Ja } \\
\text { Antal af alle } \\
\text { deltagende } \\
\text { pædagoger i } \\
\%\end{array}$ & $\begin{array}{c}\text { Ja } \\
\text { Antal af alle } \\
\text { deltagende } \\
\text { omsorgsmed- } \\
\text { hjælpere i \% }\end{array}$ \\
\hline 3-ugers AMU-kursus & 9 & 10 & 6 \\
\hline Andet/ andre AMU-kurser & 17 & 20 & 11 \\
\hline $\begin{array}{l}\text { Andre eksterne pædagogi- } \\
\text { ske kurser, da hvilke:* }\end{array}$ & 35 & 39 & 24 \\
\hline $\begin{array}{l}\text { Længerevarende efter- } \\
\text { / videreuddannelse (f.eks. } \\
\text { Diplom eller Master) }\end{array}$ & 6 & 8 & 2 \\
\hline
\end{tabular}

* Blandt 'Andre eksterne pædagogiske kurser' nævnes psykiatri, introduktionskursus, personlig udvikling, demens, sikkerhed, førstehjælp, edb, magtanvendelseskursus, neuropædagogik, epilepsi, anerkendende relationer, Kbh. kommunes intro kursus, etisk kodeks, pædagogik - ikke magt.

På spørgsmål om eksterne kurser inden for det sidste år og på ny kun med svar fra de pædagoger og omsorgsmedhjælpere, der overhovedet har deltaget i kurser, er ét kursus også her det typiske, men sammenlignet med de interne kurser, er der tale om lidt længerevarende kursusvirksomhed, idet $60 \%$ fra begge medarbejdergrupper har deltaget i kurser i mere end 33 timer mod henholdsvis 26 \% pædagoger og 33 \% omsorgsmedhjælpere i forhold til de interne kurser. 
Tabel 31B. (uddrag). Hvor mange eksterne kurser har du haft på det pædagogiske område inden for det sidste år, og hvad er (cirka) det samlede antal kursustimer?

\begin{tabular}{|l|c|c|}
\hline Antal eksterne kurser & Antal pædagoger i \% & $\begin{array}{c}\text { Antal omsorgsmedhjælpe- } \\
\text { re i \% }\end{array}$ \\
\hline 1 & 62 & 57 \\
\hline 2 & 28 & 7 \\
\hline 3 eller flere & 10 & 36 \\
\hline
\end{tabular}

\begin{tabular}{|l|c|c|}
\hline $\begin{array}{l}\text { Antal timer i alt på eks- } \\
\text { terne kurser }\end{array}$ & $\begin{array}{c}\text { Antal pædagoger } \\
\text { i } \%\end{array}$ & $\begin{array}{c}\text { Antal omsorgsmedhjælpe- } \\
\text { re i \% }\end{array}$ \\
\hline Op til 16 timer & 26 & 20 \\
\hline 17-32 timer & 17 & 20 \\
\hline 33-64 timer & 26 & 50 \\
\hline Over 64 timer & 33 & 10 \\
\hline
\end{tabular}

Et andet mål for kompetence- og kvalifikationsprofil er de uddannelsesbaggrunde, medarbejderne har med sig ind i deres nuværende job, såvel de direkte professionsrettede pædagogiske uddannelser som andre uddannelser, der eventuel kan udgøre et erfaringsberedskab, der kan trækkes på i det daglige. Det handler næste afsnit om.

\section{Medarbejdernes uddannelsesbaggrund}

Ses først på en dedikeret pædagogisk uddannelsesbaggrund gælder det ikke overraskende praktisk talt alle pædagoger (99\%), men der er også $18 \%$ af omsorgsmedhjælperne, der sætter kryds ved en pædagogisk uddannelse, jf. tabel 28 :

Tabel 28. Pædagogisk uddannelse

\begin{tabular}{|l|c|c|}
\hline $\begin{array}{l}\text { Har du pædagogisk uddan- } \\
\text { nelse? }\end{array}$ & $\begin{array}{c}\text { Ja } \\
\text { Antal i \% }\end{array}$ & $\begin{array}{c}\text { Nej } \\
\text { Antal i \% }\end{array}$ \\
\hline Alle & 77 & 23 \\
\hline Pædagoger & 99 & 1 \\
\hline Omsorgsmedhjælpere & 18 & 82 \\
\hline
\end{tabular}

$18 \%$ omsorgsmedhjælpere svarer i faktisk antal til 11 omsorgsmedhjælpere, og i tabel 28A fremgår, at det først og fremmest angår PGU og Omsorgsassistent, som her medregnes som pædagogisk uddannelsesbaggrund blandt omsorgsmedhjælperne. 
Tabel 28A. Pædagogisk uddannelse

\begin{tabular}{|l|c|c|c|}
\hline Pædagogisk uddannelse & $\begin{array}{c}\text { Ja } \\
\text { Antal af alle } \\
\text { deltagende } \\
\text { medarbejdere i } \\
\%\end{array}$ & $\begin{array}{c}\text { Ja } \\
\text { Antal af alle } \\
\text { deltagende } \\
\text { pædagoger i }\end{array}$ & $\begin{array}{c}\text { Ja } \\
\text { intal af alle } \\
\text { deltagende } \\
\text { omsorgsmed- } \\
\text { hjælpere i \% }\end{array}$ \\
\hline $\begin{array}{l}\text { Uddannet pæda- } \\
\text { gog/ socialpædagog }\end{array}$ & 68 & 93 & 3 \\
\hline $\begin{array}{l}\text { Pædagogisk Grunduddan- } \\
\text { nelse (PGU) }\end{array}$ & 2 & 1 & 6 \\
\hline Læreruddannelse & 2 & 2 & 2 \\
\hline $\begin{array}{l}\text { Cand.pæd., master eller } \\
\text { lignende uddannelse }\end{array}$ & 2 & 2 & 2 \\
\hline $\begin{array}{l}\text { Anden pædagogik uddan- } \\
\text { nelse, da hvilken? } *\end{array}$ & 9 & 9 & 9 \\
\hline
\end{tabular}

* Omsorgsassistent nævnes af flere

For pædagogernes vedkommende har de uddannede alle en pædagogisk uddannelse. Et par stykker har endvidere en PGU. I faktisk antal er tre læreruddannet og et tilsvarende antal har en overbygning på den pædagogiske uddannelse. Endelig har femten en anden pædagogisk uddannelse. Blandt omsorgsmedhjælperne har to en pædagoguddannelse, fire en PGU, og der er en person, som er uddannet lærer og en anden har en overbygningsuddannelse på pædagoguddannelsen.

Hvorledes ser det ud, når der spørges til andre uddannelsesbaggrunde end en pædagogisk? Det må især forventes at gælde for omsorgsmedhjælpere, hvoraf nogle har arbejdet inden for andre erhvervssektorer inden de skiftede til omsorgsmedhjælpererhvervet.

Her er det samlede billede at halvdelen af omsorgsmedhjælperne tilkendegiver, at de har en anden uddannelse end en pædagogisk, men der er også en tredjedel af pædagogerne, der svarer således, hvilket indikerer, at et relativt stort antal medarbejdere har dobbelt uddannelsesbaggrund bag sig:

Tabel 29. Anden uddannelse end en pædagogisk uddannelse.

\begin{tabular}{|l|c|c|}
\hline $\begin{array}{l}\text { Har du en anden uddan- } \\
\text { nelse end en pædagogisk } \\
\text { uddannelse? }\end{array}$ & $\begin{array}{l}\text { Ja } \\
\text { Antal i \% }\end{array}$ & Antal i \% \\
\hline Alle & 38 & 62 \\
\hline Pædagoger & 33 & 67 \\
\hline Omsorgsmedhjælpere & 50 & 50 \\
\hline
\end{tabular}

Et 'naturligt' delspørgsmål er her hvilken? 
Tabel 29A. Art af anden uddannelse.

\begin{tabular}{|l|c|c|c|}
\hline $\begin{array}{l}\text { Hvis ja til anden uddan- } \\
\text { nelse, hvilken uddannelse } \\
\text { er der da tale om? }\end{array}$ & $\begin{array}{c}\text { Ja } \\
\text { Antal af alle } \\
\text { deltagende } \\
\text { medarbejdere i } \\
\%\end{array}$ & $\begin{array}{c}\text { Ja } \\
\text { Antal af alle } \\
\text { deltagende } \\
\text { pædagoger i i } \\
\%\end{array}$ & $\begin{array}{c}\text { Ja } \\
\text { Antal af alle } \\
\text { deltagende } \\
\text { omsorgsmed- } \\
\text { hjælpere i \% }\end{array}$ \\
\hline $\begin{array}{l}\text { Lang videregående ud- } \\
\text { dannelse (eks. universi- } \\
\text { tetsuddannelse) }\end{array}$ & 6 & 5 & 11 \\
\hline $\begin{array}{l}\text { Mellemlang videregående } \\
\text { uddannelse (eks. sygeple- } \\
\text { jerske) }\end{array}$ & 3 & 1 & 8 \\
\hline $\begin{array}{l}\text { Handels-/ kontor-/ service- } \\
\text { / håndværkeruddannelse } \\
\text { o.l. }\end{array}$ & 13 & 13 & 14 \\
\hline $\begin{array}{l}\text { Social- og Sundhedsassi- } \\
\text { stent (SoSu) }\end{array}$ & 3 & 3 & 5 \\
\hline Anden uddannelse $*$ & 14 & 14 & 15 \\
\hline
\end{tabular}

* Under 'Anden uddannelse' nævnes eksempelvis sygehjælper, zoneterapeut, psykoterapeut, NLP-massør.

Blandt pædagogerne har - i faktisk antal - otte personer en lang videregående uddannelse og to personer har en mellemlang uddannelse. En større gruppe af pædagoger har en praktisk uddannelse, mens en gruppe på fem personer har en kort uddannelse som Social- og Sundhedsassistent. Blandt omsorgsmedhjælperne er der syv personer med en lang videregående uddannelse, og fem personer med mellemlang videregående uddannelse. En kort uddannelse har ni personer, mens tre personer har en SoSu uddannelse.

Inden for andre pædagogiske arbejdsområder - f.eks. daginstitutioner ${ }^{63}$ - er mange medarbejderes erfaring, at deres ikke pædagogiske uddannelse er nyttig erfaringsbaggrund også i pædagogisk arbejde, og det samme indtryk tegner sig som inden for botilbudsområdet, hvor under en fjerdedel svarer 'nej' på et delspørgsmål herom:

Tabel 29B. Om den anden uddannelse opleves at kunne bruges i det pædagogiske arbejde

\begin{tabular}{|l|c|c|c|}
\hline $\begin{array}{l}\text { Hvis ja til anden uddan- } \\
\text { nelse, oplever du så at } \\
\text { kunne bruge denne i dit } \\
\text { pædagogiske arbejde }\end{array}$ & $\begin{array}{c}\text { Ja } \\
\text { Antal i \% }\end{array}$ & $\begin{array}{c}\text { Nej } \\
\text { Antal i \% }\end{array}$ & $\begin{array}{l}\text { Ved ikke } \\
\text { Antal i \% }\end{array}$ \\
\hline Alle & 68 & 24 & 8 \\
\hline Pædagoger & 71 & 24 & 5 \\
\hline Omsorgsmedhjælpere & 62 & 23 & 15 \\
\hline
\end{tabular}

\footnotetext{
${ }^{63}$ Se Bryderup, Langager og Robenhagen 2000.
} 


\section{Medarbejdere under uddannelse}

Et andet spørgsmål med relation til uddannelse er, hvorvidt mange medarbejdere er under uddannelse samtidigt med arbejdet i botilbuddet. Selvom unders $\emptyset$ gelsen ikke omfatter tilkaldevikarer og løsere ansatte omsorgsmedhjælpere, kan en del af dem, der som opgjort i tabel 12 som deltidsarbejdende (herunder eksempelvis de $15 \%$ omsorgsmedhjælpere med mindre en 19 ugentlige arbejdstimer) eventuelt være under samtidig uddannelse.

Det viser sig at gælde for næsten en tredjedel af omsorgsmedhjælperne:

Tabel 30. Er du under uddannelse

\begin{tabular}{|l|c|c|}
\hline Er du under uddannelse? & $\begin{array}{c}\text { Ja } \\
\text { Antal i \% }\end{array}$ & $\begin{array}{c}\text { Nej } \\
\text { Antal i \% }\end{array}$ \\
\hline Alle & 15 & 85 \\
\hline Pædagoger & 8 & 92 \\
\hline Omsorgsmedhjælpere & 31 & 69 \\
\hline
\end{tabular}

$31 \%$ omsorgsmedhjælpere og $9 \%$ pædagoger er under uddannelse samtidig med arbejdet i botilbud, og tabel 30A giver et overblik over hvilke typer uddannelse, der er tale om:

Tabel 30A. Hvis 'ja' til at du er under uddannelse, hvilken type uddannelse?

\begin{tabular}{|l|c|c|c|}
\hline $\begin{array}{l}\text { Hvis 'ja' til at du er under } \\
\text { uddannelse, hvilken type } \\
\text { uddannelse? }\end{array}$ & $\begin{array}{c}\text { Ja } \\
\text { Antal af alle } \\
\text { deltagende } \\
\text { medarbejdere i } \\
\%\end{array}$ & $\begin{array}{c}\text { Ja } \\
\text { Antal af alle } \\
\text { deltagende } \\
\text { pædagoger i i } \\
\%\end{array}$ & $\begin{array}{c}\text { Ja } \\
\text { Antal af alle } \\
\text { deltagende } \\
\text { omsorgsmed- } \\
\text { hjælpere i \% }\end{array}$ \\
\hline Pædagogisk uddannelse & 7 & 2 & 18 \\
\hline $\begin{array}{l}\text { Mellemlang videregående } \\
\text { uddannelse (eks. sygeple- } \\
\text { jerske) }\end{array}$ & 2 & 1 & 6 \\
\hline $\begin{array}{l}\text { Lang videregående ud- } \\
\text { dannelse (eks. universi- } \\
\text { tetsuddannelse) }\end{array}$ & 4 & 2 & 11 \\
\hline $\begin{array}{l}\text { Handels-/ kontor- } \\
\text { / serviceuddannelse }\end{array}$ & 1 & 0 & 2 \\
\hline Håndværkeruddannelse & 4 & 2 & 11 \\
\hline $\begin{array}{l}\text { Anden uddannelse, hvil- } \\
\text { ken: }\end{array}$ & 2 & 2 & 2 \\
\hline
\end{tabular}

De fleste omsorgsmedhjælpere, der er i gang med en uddannelse, er det i forhold til en pædagogisk uddannelse. Det drejer sig i faktiske tal om tolv personer ud af de seksog- 
tres, der deltager i undersøgelsen. En mindre gruppe er i gang med lang eller anden mellemlang uddannelse, mens kun to personer er i gang med praktiske uddannelser.

Blandt de pædagoger der er i gang med en uddannelse er fire i gang med en pædagogisk uddannelse, fem er $\mathrm{i}$ gang med en lang videregående uddannelse og fire er i gang med anden uddannelse $e^{64}$.

\section{Arbejdserfaringer og kompetenceprofiler}

En sidste brik i den faktuelt orienterede karakteristik af medarbejdere i botilbud til voksne med udviklingshæmning er medarbejdernes arbejdserfaringer forud for nuværende arbejdsplads, herunder hvorvidt disse erfaringer kan henregnes til en slags pædagogisk kompetenceprofil i kraft af, at erfaringerne stammer fra arbejde inden for andre pædagogiske og omsorgsrettede områder ${ }^{65}$.

Først repeteres tabel 11, der viser, at medarbejderne sammenlignet med alder samlet set har relativ kort anciennitet inden for den aktuelle arbejdsplads (jf. kapitel 2):

Tabel 11. Længde af din nuværende ansættelse

\begin{tabular}{|l|c|}
\hline $\begin{array}{l}\text { Længde af nuværende } \\
\text { ansættelse? }\end{array}$ & $\begin{array}{c}\text { Alle } \\
\text { Antal i \% }\end{array}$ \\
\hline Fra 3 år til under 5 år & 60 \\
\hline Fra 5 år til under 10 år & 21 \\
\hline Fra 10 år til under år 20 ar & 19 \\
\hline Fra 20 år og opefter & 0 \\
\hline
\end{tabular}

Under en femtedel (19 \%) har mere end 10 års anciennitet på nuværende arbejdsplads, og sammenlignes her med den samlede anciennitetsprofil alene inden for bo- og dagtilbud, hvor 40 \% markerer, at de har mere end ti år bag sig i bo- og dagtilbud arbejdsmæssigt, tydeliggøres, at der er tale om en medarbejdergruppe med langt længere deltagelse på arbejdsmarkedet end længden af nuværende ansættelse indikerer.

\footnotetext{
${ }^{64}$ Spørgsmålet om uddannelsesforløb samtidig med arbejdet i bo- og dagtilbud er i øvrigt et af de få områder, hvor svarmønstrene adskiller sig markant fra den landsdækkende omsorgsmedhjælperundersøgelse. I den angiver kun $6 \%$ af omsorgsmedhjælperne (mod $31 \%$ i'Københavnerunders $\varnothing g e l s e n ')$, at de er under uddannelse sideløbende med arbejdet. En forskel, der må ses i sammenhæng dels med at

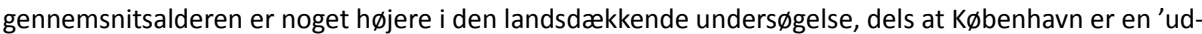
dannelsesby', som mange, der ønsker at uddanne sig, bosætter sig i af den årsag og derfor tager sideløbende arbejde her. Se Robenhagen, Langager, Højmark og Allerup (2009).

${ }^{65}$ I undersøgelsen er kun spurgt ind til tidligere erhvervserfaring inden for den pædagogiske og omsorgsrettede sektor. Hvorvidt en del har årelange erfaringer fra helt andre erhverv kan der således ikke svares på.
} 
Tabel 33. Samlet antal år ansat inden for området.

\begin{tabular}{|l|c|}
\hline $\begin{array}{l}\text { Samlet længde af an- } \\
\text { sættelse inden for om- } \\
\text { rådet voksne udvik- } \\
\text { lingshæmmede og/ eller } \\
\text { fysisk handicappede }\end{array}$ & Antal i \% \\
\hline Under 5 år & 35 \\
\hline Fra 5 år til under 10 år & 26 \\
\hline Fra 10 år til under 15 år & 13 \\
\hline Fra 15 år til under år 20 år & 7 \\
\hline Fra 20 år og opefter & 20 \\
\hline
\end{tabular}

Et mere nuanceret billede kan tegnes ud fra svarmønstrene i tabel 32, hvor der spørges ind til tidligere arbejdserfaringer i bredere betydning:

Tabel 32. Arbejdserfaringer inden nuværende job?

\begin{tabular}{|l|c|c|}
\hline $\begin{array}{l}\text { Har du haft andre arbejdserfarin- } \\
\text { ger/ job efter afsluttet sko- } \\
\text { le/ uddannelse, som ligger før dit } \\
\text { nuværende job? }\end{array}$ & $\begin{array}{c}\text { Ja } \\
\text { Antal i \% }\end{array}$ & $\begin{array}{c}\text { Nej } \\
\text { Antal i \% }\end{array}$ \\
\hline Alle & 88 & 12 \\
\hline Pædagoger & 89 & 11 \\
\hline Omsorgsmedhjælpere & 86 & 14 \\
\hline
\end{tabular}

Langt hovedparten (88 \%) af alle pædagoger og omsorgsmedhjælpere har andre arbejdserfaringer at trække på, eller udtrykt på en anden måde: Kun lidt flere end hver tiende medarbejder (12\%) har nuværende arbejdsplads som den første tilknytning til arbejdsmarkedet som voksen.

Differentieres de tidligere arbejdsmæssige erfaringer på forskellige arbejdsområder, er svarmønstrene: 
Tabel 32A. Hvis 'ja' til arbejdserfaringer, er det erfaringer fra det pædagogiske/omsorgsmæssige område?

\begin{tabular}{|c|c|c|}
\hline $\begin{array}{l}\text { Hvis 'ja' til arbejdserfaringer, er } \\
\text { det erfaringer fra det pædagogi- } \\
\text { ske/ omsorgsmæssige omrăde? }\end{array}$ & $\begin{array}{c}\text { Ja } \\
\text { Antal i \% }\end{array}$ & $\begin{array}{c}\text { Nej } \\
\text { Antal i \% }\end{array}$ \\
\hline \multicolumn{3}{|c|}{$\begin{array}{l}\text { Har du arbejdserfaringer som omsorgsmedhjælper, pædagog, mv. i for- } \\
\text { hold til voksne med udviklingshæmning og/ eller fysisk handicappede }\end{array}$} \\
\hline Alle & 73 & 27 \\
\hline Pædagoger & 77 & 23 \\
\hline Omsorgsmedhjælpere & 61 & 39 \\
\hline \multicolumn{3}{|c|}{ Har du arbejdserfaringer fra ældreplejen } \\
\hline Alle & 48 & 52 \\
\hline Pædagoger & 48 & 52 \\
\hline Omsorgsmedhjælpere & 47 & 53 \\
\hline \multicolumn{3}{|c|}{ Har du arbejdserfaringer fra SFO/ fritidshjem } \\
\hline Alle & 50 & 50 \\
\hline Pædagoger & 57 & 43 \\
\hline Omsorgsmedhjælpere & 33 & 67 \\
\hline \multicolumn{3}{|c|}{$\begin{array}{l}\text { Har du arbejdserfaringer fra daginstitution (vuggestue, børnehave eller } \\
\text { lign.) }\end{array}$} \\
\hline Alle & 82 & 18 \\
\hline Pædagoger & 87 & 13 \\
\hline Omsorgsmedhjælpere & 68 & 32 \\
\hline \multicolumn{3}{|l|}{ Andre erfaringer: da hvilke? $*$} \\
\hline Alle & 94 & 6 \\
\hline Pædagoger & 93 & 7 \\
\hline Omsorgsmedhjælpere & 95 & 5 \\
\hline
\end{tabular}

* Blandt 'Andre erfaringer' nævnes sygehjælper, klub, lærer, undervisning, vikar i børnehave, kunst/teater mm. Industri og hotel, kontor og hulledame, bh. Klasse. Uddannet inden for tøjbranchen, narkomaner, alkoholikere og anbragte børn, handicapmedhjælper, master uddannelse i pædagogik, pige i huset, butiksarbejde, arbejde med voksne skizofrene, borderline, misbrugere, spiseforstyrrelser.

Omkring to ud af tre pædagoger og omsorgsmedhjælpere har tidligere joberfaring inden for undersøgelsens målområde, hvilket stemmer godt overens med tabel 33.

De fleste medarbejdere har endvidere joberfaringer forud fra dagtilbudsområdet, men også erfaringer fra ældrepleje eller fra SFO/fritidsområdet er rigt repræsenteret blandt de $88 \%$ af medarbejderne, der har angivet at have joberfaringer, der ligger forud for nuværende ansættelse. 


\section{Mobilitet og fremtidsforventninger}

Afslutningsvist i kapitel 7 skal endnu engang inddrages det spørgsmål, der kan angive et indirekte mål for erhvervsmæssig mobilitet; nemlig hvorvidt medarbejderne i et treårigt fremtidsperspektiv ser sig selv som arbejdende på nuværende arbejdsplads?

Op mod halvdelen af pædagogerne (46 \%) svarer bekræftende herpå, og lægges det procenttal sammen med dem, der tror de fortsat arbejder $\mathrm{i}$ bo- og dagtilbud, men et andet sted, er andelen næste tre ud af fire pædagoger (72\%). Og lægges hertil de 8 \%, der tror eller ved, at de har nået en alder, hvor de forlader arbejdsmarkedet, er det kun hver femte pædagog (20\%), der forestiller sig, at de laver noget helt andet, er under uddannelse eller barselsorlov.

Tabel 35. Forventninger til fremtiden. Hvad tror du, at du laver om tre år?

\begin{tabular}{|l|c|}
\hline $\begin{array}{l}\text { Forventninger til fremtiden. Hvad tror du, at du } \\
\text { laver om tre år? Pædagoger }\end{array}$ & $\begin{array}{c}\text { Antal pædagoger i \% } \\
\mathrm{N}=155\end{array}$ \\
\hline Jeg arbejder på min nuværende arbejdsplads & 46 \\
\hline $\begin{array}{l}\text { Jeg arbejder inden for arbejdsområdet, men et andet } \\
\text { sted }\end{array}$ & 26 \\
\hline Jeg er under videreuddannelse & 6 \\
\hline Jeg har andet arbejde & 2 \\
\hline Jeg er på barsel & 8 \\
\hline Jeg er på efterløn eller pension & 6 \\
\hline Jeg laver noget helt andet & 6 \\
\hline
\end{tabular}

Helt så markant mht. til 'livslangt' arbejde inden for bo- og dagtilbud ser situationen ikke ud blandt omsorgsmedhjælperne, når de skal prøve at se tre år ud i fremtiden.

Men det er trods alt halvdelen (49\%), der forventer at arbejde på samme sted eller et tilsvarende. $20 \%$ (mod $6 \%$ pædagoger) tror eller ved, de vil være under uddannelse, mens en lille tredjedel ( $31 \%$ ) tror de har arbejde inden for et andet erhvervsområde eller i bredere forstand 'laver noget helt andet'. 


\begin{tabular}{|l|c|}
\hline $\begin{array}{l}\text { Forventninger til fremtiden. Hvad tror du, at du } \\
\text { laver om tre år? Omsorgsmedhjælpere }\end{array}$ & $\begin{array}{c}\text { Antal omsorgsmed- } \\
\text { hjælpere i \% } \\
\mathrm{N}=59\end{array}$ \\
\hline Jeg arbejder på min nuværende arbejdsplads & 39 \\
\hline $\begin{array}{l}\text { Jeg arbejder inden for arbejdsområdet, men et andet } \\
\text { sted }\end{array}$ & 10 \\
\hline Jeg går på professionshøjskole for at blive pædagog & 10 \\
\hline $\begin{array}{l}\text { Jeg går på Pædagogisk Assistent Uddannelse (tidligere } \\
\text { PGU) }\end{array}$ & 0 \\
\hline Jeg er under anden uddannelse & 10 \\
\hline Jeg har andet arbejde & 22 \\
\hline Jeg er på barsel & 0 \\
\hline Jeg er på efterløn eller pension & 0 \\
\hline Jeg laver noget helt andet & 9 \\
\hline
\end{tabular}

Samlet et indtryk af en medarbejdergruppe, der har mange års erfaring inden for den pædagogiske sektor og heraf mange inden for bo- og dagtilbudsområdet for voksne med varig psykisk funktionsnedsættelse.

En medarbejdergruppe, hvor der dog også - og især blandt omsorgsmedhjælperne - er en del, der er under sideløbende uddannelse eller som forventer at være det om tre år, men samlet set en meget stor andel blandt såvel pædagoger (72 \%) og omsorgsmedhjælpere (49\%), der forventer at være erhvervsaktive i bo- og dagtilbud også om tre år.

Det betyder, at hovedparten af de medarbejdere, der deltager i undersøgelsen, også vil være at finde blandt dem, der skal bidrage med fagligt udviklingsarbejde i de kommende år, og da erfaringsprofilen samtidig antyder, at der er tale om en medarbejdergruppe, hvor de fleste har erfaringer med, hvor 'skoen eventuelt trykker' faglig set $\mathrm{i}$ bo- og dagtilbud for voksne udviklingshæmmede, er det nærliggende at spørge ind til, hvordan fagligt udviklingsarbejde og organisationsudvikling med fordel kan prioriteres.

Det er temaet i næste kapitel. 


\section{Kapitel 8}

\section{Synspunkter på fagligt udviklingsarbejde, le- delse og organisation}

I dette sidste kapitel før afslutningen vendes blikket på ny mod mere holdningsorienterede spørgsmål, nemlig hvilke vurderinger og prioriteringer, de deltagende pædagoger og omsorgsmedhjælpere har i forhold til fagligt udviklingsarbejde i botilbuddet, hvad de væsentligste pædagogiske funktioner i botilbuddet vurderes at være, og hvorledes ledelse og organisation erfares i det botilbud, de er ansat.

\section{Prioritering af faglige udviklingsinitiativer $\mathrm{i}$ botilbud}

Med afsæt i de overvejelser over vigtige indsatsområder for fagligt udviklingsarbejde i botilbud for voksne med handicap, som arbejdsgruppen bag rapporten 'Veje til et godt liv i egen bolig' udarbejdede i $2007^{66}$, og med inddragelse af de fem fokusområder og konkrete udviklingsinitiativer, som Socialudvalget i Københavns Kommune besluttede i foråret $2007^{67}$, kom spørgeskemaets spørgsmål 27 til at rumme seks potentielt centrale faglige udviklingsområder, som medarbejderne blev bedt om at prioritere vigtigheden af. Ikke specificeret ift. egen arbejdsplads, men ud fra erfaringer og kendskab til området som helhed.

Spørgsmålet lød: "Hvilke to af nedenstående 6 mulige indsatsområder til styrkelse af bo- og dagtilbud mener du bør prioriteres højest ud fra dit kendskab til området som helhed?" Alle havde således mulighed for at sætte to krydser, som typisk giver mulighed for lidt større spredning i prioriteringerne sammenlignet med kun én valgmulighed, men at dømme efter svarmønstrene er der ikke tvivl om, hvad som vurderes som de to vigtigste indsatsområder:

\footnotetext{
${ }^{66}$ Jf. omtalen af rapporten i kapitel 1 og 3 (Socialministeriet 2007).

${ }^{67}$ Socialudvalget 2007.
} 
Tabel 27. Udviklingsinitiativer generelt inden for bo- og dagtilbud

\begin{tabular}{|l|c|c|}
\hline $\begin{array}{l}\text { Udviklingsinitiativer gene- } \\
\text { relt inden for bo- og dagtil- } \\
\text { bud. Prioritering fra 1 til 6 } \\
\text { ( 1 er højest rangeret) }\end{array}$ & $\begin{array}{c}\text { Alle } \\
\text { Prioritering i nummer }\end{array}$ & $\begin{array}{c}\text { Alle } \\
\text { Prioritering i \% }\end{array}$ \\
\hline $\begin{array}{l}\text { Faglighed, kompetenceudvikling } \\
\text { og efteruddannelse }\end{array}$ & 1 & $40 \%$ \\
\hline $\begin{array}{l}\text { Pædagogisk udvikling, holdnin- } \\
\text { ger og værdier }\end{array}$ & 2 & $36 \%$ \\
\hline Rekruttering og introduktion & 3 & $6 \%$ \\
\hline Arbejdets organisering & 4 & $6 \%$ \\
\hline $\begin{array}{l}\text { Bruger- og pårørendeinddragel- } \\
\text { se }\end{array}$ & 5 & $5 \%$ \\
\hline Ledelsesudvikling & 6 & \\
\hline
\end{tabular}

Tre fjerdedele af alle krydserne er sat ved henholdsvis 'Faglighed, kompetenceudvikling og efteruddannelse' (40 \%) og 'Pædagogisk udvikling, holdninger og værdier' (36 $\%)$. De resterende fire valgmuligheder må deles om den sidste fjerdel, og her ligger antallet af svar under de forskellige valgmuligheder så tæt, at det kun er fem krydser (ud af 473), der skiller prioritering nummer 3 fra nummer 6.

En meget markant udmelding fra medarbejderne om at faglige udviklingsinitiativer først og fremmest bør prioritere de ansattes kompetenceudvikling og efteruddannelse med særligt fokus på pædagogik holdninger og værdier i arbejdet, mens mere organisations- og ledelseskompetenceudviklende initiativer vurderes som langt mindre vigtige med ledelsesudvikling på sidste prioritetsplads.

Ses der på forskelle i prioriteringer mellem pædagoger, omsorgsmedhjælpere og ledere i København ${ }^{68}$, og medtages resultater fra den landsdækkende omsorgsmedhjælperundersøgelse ${ }^{69}$, er der ikke de store forskelle. Alle fire grupperinger har 'Faglighed, kompetenceudvikling og efteruddannelse' og 'Pædagogisk udvikling, holdninger og værdier' på to klare første- og andenprioritetspladser (lederne har pædagogik, holdninger og værdier $\varnothing$ verst, mens de tre medarbejdergrupper har faglighed og kompetenceudvikling som første prioritet), jf. følgende oversigt:

\footnotetext{
${ }^{68}$ Som tidligere nævnt udfyldte lederne et mindre spørgeskema, hvori nogle af spørgsmålene var identiske med spørgsmål i medarbejderskemaet.

${ }^{69}$ Robenhagen, Langager, Højmark og Allerup (2009).
} 
Tabel 27s. Udviklingsinitiativer generelt inden for bo- og dagtilbud

\begin{tabular}{|l|c|c|c|c|}
\hline $\begin{array}{l}\text { Udviklingsinitiativer gene- } \\
\text { relt inden for bo- og dagtil- } \\
\text { bud. Prioritering fra nummer } \\
\mathbf{1} \text { til 6 }\end{array}$ & $\begin{array}{c}\text { Ledere i } \\
\text { Køben- } \\
\text { havn }\end{array}$ & $\begin{array}{c}\text { Pædago- } \\
\text { ger i Kø- } \\
\text { benhavn }\end{array}$ & $\begin{array}{c}\text { Omsorgs- } \\
\text { med- } \\
\text { hjælpere } \\
\text { i Køben- } \\
\text { havn }\end{array}$ & $\begin{array}{c}\text { Omsorgs- } \\
\text { med- } \\
\text { hjælpere } \\
\text { på lands- } \\
\text { plan }\end{array}$ \\
\hline $\begin{array}{l}\text { Faglighed, kompetenceudvikling } \\
\text { og efteruddannelse }\end{array}$ & 2 & 1 & 1 & 1 \\
\hline $\begin{array}{l}\text { Pædagogisk udvikling, holdnin- } \\
\text { ger og værdier }\end{array}$ & 1 & 2 & 2 & 2 \\
\hline Rekruttering og introduktion & 5 & 5 & 3 & 4 \\
\hline Arbejdets organisering & 4 & 6 & 4 & 3 \\
\hline $\begin{array}{l}\text { Bruger- og pårørendeinddragel- } \\
\text { se }\end{array}$ & 6 & 4 & 5 & 6 \\
\hline Ledelsesudvikling & 3 & 3 & 6 & 5 \\
\hline
\end{tabular}

Ses der efter variationer på de følgende fire prioriteringer har ledere og pædagoger 'Ledelsesudvikling' på tredje pladsen, mens københavnske omsorgsmedhjælpere har den som sidste prioritet. Omsorgsmedhjælpere på landsplan har 'Arbejdets organisering' på tredjepladsen, mens pædagogerne i København har den til sidst, men der er som nævnt så små forskelle i antallet af krydser i de fire svarkategorier, at der ikke kan uddrages klare konklusioner på variationerne i prioritering 3 til 6.

\section{Medarbejdernes vurdering af ledelse og organisation i botilbud}

Den lave prioritering af vigtigheden af organisations- og ledelsesudvikling blandt medarbejderne antyder, at det er et aspekt af det daglige arbejde, der ikke volder de helt store problemer eller er genstand for kritik fra medarbejderside.

Som helhed - på tværs af de deltagende botilbud - peger svarmønstrene i spørgsmål 19, der er det spørgsmål i spørgeskemaet, der mest direkte angår medarbejdernes vurdering af organisation og ledelse, da heller ikke i retning af massiv utilfredshed med den måde, botilbuddet er ledet og organiseret: 
Tabel 19. Oplevelse af ledelse og organisering af bo-/dagtilbuddet

\begin{tabular}{|c|c|c|c|c|}
\hline $\begin{array}{l}\text { Oplevelse af ledelse og orga- } \\
\text { nisering af bo-/ dagtilbuddet }\end{array}$ & $\begin{array}{l}\text { Slet ikke } \\
\text { Antal i \% }\end{array}$ & $\begin{array}{l}\text { I mindre } \\
\text { eller no- } \\
\text { gen } \\
\text { grad }^{70} \\
\text { Antal i \% }\end{array}$ & $\begin{array}{l}\text { I høj grad } \\
\text { Antal i \% }\end{array}$ & $\begin{array}{c}\text { Ved ikke } \\
\text { / ønsker } \\
\text { ikke } \\
\text { at svare } \\
\text { Antal i \% }\end{array}$ \\
\hline $\begin{array}{l}\text { Måden bo-/ dagtilbuddet som hel- } \\
\text { hed ledes på er for uprofessionel }\end{array}$ & 57 & 35 & 5 & 2 \\
\hline $\begin{array}{l}\text { Der er for langt fra 'gulvet' til le- } \\
\text { delsen af bo-/dagtilbuddet }\end{array}$ & 51 & 42 & 6 & 2 \\
\hline $\begin{array}{l}\text { Der er for lidt selvstændighed } \\
\text { (uddelegering af ansvaret) til de } \\
\text { enkelte enheder/afdelinger på bo- } \\
\text { /dagtilbuddet }\end{array}$ & 71 & 23 & 2 & 4 \\
\hline $\begin{array}{l}\text { Organiseringen af bo-/ dagtilbud- } \\
\text { det i de nuværende afdelin- } \\
\text { ger/enheder er ikke så hensigts- } \\
\text { mæssig, som den kunne være }\end{array}$ & 35 & 50 & 5 & 9 \\
\hline $\begin{array}{l}\text { Der er for lidt opmærksomhed } \\
\text { omkring vigtigheden af at introdu- } \\
\text { cere/'oplære' nye medarbejdere } \\
\text { (fastansatte og vikarer) grundigt } \\
\text { til deres nye job }\end{array}$ & 47 & 43 & 8 & 2 \\
\hline
\end{tabular}

Et relativt beskedent antal medarbejdere - mellem $2 \%$ og $8 \%$ - markerer, at de 'i høj grad' er utilfredse med måden botilbuddet er organiseret, mens flertallet 'slet ikke' mener at stedet ledes uprofessionelt (57\%), eller at der er for langt fra 'gulv til ledelse' (51\%), eller at der er for lidt uddelegering af ansvar, som hele $71 \%$ svarer 'slet ikke' til.

Kun i to ud af de fem spørgsmål er andelen af helt tilfredse medarbejdere under 50 $\%$, nemlig i spørgsmålet om hvorvidt bostedet kunne organiseres bedre med hensyn til strukturering af afdelinger mv., hvor en tredjedel (35 \%) 'slet ikke' oplever problemer med strukturen, og i forbindelse med måden, nye medarbejdere introduceres på stedet (47\% svarer her 'slet ikke' problemer).

Svarfordelingerne ovenfor er som nævnt for alle botilbud, og på spørgsmål om ledelse og organisation er det nærliggende at se efter, om det skulle vise sig større variationer mellem medarbejdere i større botilbud og mindre bofællesskaber mv. enheder.

Deles svarene på de fem spørgsmål op i henholdsvis botilbud (uden dagtilbud) og bofællesskaber mv., tegner der sig følgende fordeling:

\footnotetext{
${ }^{70}$ Svarmulighederne 'I mindre grad' og 'I nogen grad' er her slået sammen. Se bilag 3 for den mere udspecificerede fordeling.
} 
Tabel 19s. Oplevelse af ledelse og organisering af bo-/dagtilbuddet

\begin{tabular}{|c|c|c|c|c|}
\hline $\begin{array}{l}\text { Oplevelse af ledelse og orga- } \\
\text { nisering af bo-/ dagtilbuddet }\end{array}$ & $\begin{array}{l}\text { Slet ikke } \\
\text { Antal i \% }\end{array}$ & $\begin{array}{l}\text { I mindre } \\
\text { eller no- } \\
\text { gen } \\
\text { grad } \\
\text { Antal i \% }\end{array}$ & $\begin{array}{l}\text { I høj grad } \\
\text { Antal i \% }\end{array}$ & $\begin{array}{c}\text { Ved ikke } \\
\text { / ønsker } \\
\text { ikke } \\
\text { at svare } \\
\text { Antal i \% } \\
\end{array}$ \\
\hline \multicolumn{5}{|l|}{$\begin{array}{l}\text { Måden bo-/dagtilbuddet som hel- } \\
\text { hed ledes på er for uprofessionel }\end{array}$} \\
\hline Botilbud (uden dagtilbud) & 59 & 33 & 5 & 3 \\
\hline Bofælleskaber mv. & 58 & 40 & 3 & 0 \\
\hline \multicolumn{5}{|l|}{$\begin{array}{l}\text { Der er for langt fra 'gulvet' til le- } \\
\text { delsen af bo-/dagtilbuddet }\end{array}$} \\
\hline Botilbud (uden dagtilbud) & 60 & 34 & 5 & 2 \\
\hline Bofælleskaber mv. & 41 & 54 & 5 & 0 \\
\hline \multicolumn{5}{|l|}{$\begin{array}{l}\text { Der er for lidt selvstændighed } \\
\text { (uddelegering af ansvaret) til de } \\
\text { enkelte enheder/afdelinger på bo- } \\
\text { /dagtilbuddet }\end{array}$} \\
\hline Botilbud (uden dagtilbud) & 68 & 28 & 3 & 2 \\
\hline Bofælleskaber mv. & 89 & 8 & 0 & 3 \\
\hline \multicolumn{5}{|l|}{$\begin{array}{l}\text { Organiseringen af bo/dagtilbuddet } \\
\text { i de nuværende afdelin- } \\
\text { ger/enheder er ikke så hensigts- } \\
\text { mæssig, som den kunne være }\end{array}$} \\
\hline Botilbud (uden dagtilbud) & 37 & 47 & 8 & 8 \\
\hline Bofælleskaber mv. & 27 & 60 & 0 & 14 \\
\hline \multicolumn{5}{|l|}{$\begin{array}{l}\text { Der er for lidt opmærksomhed } \\
\text { omkring vigtigheden af at introdu- } \\
\text { cere/'oplære' nye medarbejdere } \\
\text { (fastansatte og vikarer) grundigt } \\
\text { til deres nye job }\end{array}$} \\
\hline Botilbud (uden dagtilbud) & 56 & 36 & 6 & 2 \\
\hline Bofælleskaber mv. & 51 & 47 & 0 & 3 \\
\hline
\end{tabular}

Ses nedover de mange procenttal, er der med hensyn til dem, der markerer 'i høj grad' problemer for begge gruppers vedkommende lave procentandele, med lidt færre fra bofællesskaber mv. (heraf $0 \%$ på tre af spørgsmålene), men mere interessant er de relativt store forskelle i 'slet ikke' svarmønstrene, hvor forskellene i tre af spørgsmålene er ganske store, helt op til $21 \%$ og med udslag til begge sider.

På spørgsmålet om der er for langt fra 'gulvet til ledelsesniveauet' markerer $60 \%$ af medarbejderne i botilbud 'slet ikke' mod 'kun' 41 \% fra bofællesskaber mv., mens det modsatte mønster gør sig gældende, når der spørges ind til om der opleves for lidt selvstændighed i det daglige arbejde. Her svarer næsten ni ud af ti (89 \%) fra bofælles- 
skaber mv. 'slet ikke', mens andelen fra botilbud er en del lavere (men fortsat de fleste), nemlig $68 \%$.

\section{Synspunkter på vigtige fokusområder $\mathrm{i}$ indsatsen for voksne med psykisk handicap}

Fra spørgsmål om erfaringer omkring organisation og ledelse lokalt vendes blikket i den sidste tabel, der indgår i afrapporteringen, på ny mod de overordnede faglige vurderinger af, hvad som vurderes vigtigst $\mathrm{i}$ den konkrete indsats for og med beboerne/brugerne.

Med reference til 'Lov om social service' formuleredes spørgeskemaets spørgsmål 9 således: "Lovbemærkningerne til serviceloven peger på forskellige delmål med indsatsen. Hvilke 2 af nedenstående 5 delmål i den daglige indsats mener du bør være højest prioriterede på det bosted/afdeling/dagtilbud, hvor du arbejder?".

Igen var der således mulighed for at sætte to krydser og svarfordelingen er her betydeligt mere jævn end i Tabel 19. Den samlede svarfordeling er:

Tabel 9. Prioritering af delmål med indsatsen i bo- og dagtilbud

\begin{tabular}{|l|c|c|}
\hline $\begin{array}{l}\text { Prioritering af delmål med indsatsen i } \\
\text { bo- og dagtilbud }\end{array}$ & $\begin{array}{c}\text { Alle } \\
\text { Prioritering i tal }\end{array}$ & $\begin{array}{c}\text { Alle } \\
\text { Prioritering i \% }\end{array}$ \\
\hline Udvikling af en positiv identitet & 1 & $28 \%$ \\
\hline Ydelse af den nødvendige omsorg & 2 & $22 \%$ \\
\hline $\begin{array}{l}\text { Mestring af aktiv livsudfoldelse i samspil med } \\
\text { andre }\end{array}$ & 3 & $18 \%$ \\
\hline $\begin{array}{l}\text { Opøvelse af færdigheder, som kan kompen- } \\
\text { sere for den nedsatte funktionsevne }\end{array}$ & 4 & $7 \%$ \\
\hline $\begin{array}{l}\text { Skabelse af forståelse og rummelighed i det } \\
\text { omgivende samfund }\end{array}$ & 5 & \\
\hline
\end{tabular}

De to højest prioriterede delmål er 'Udvikling af en positiv identitet' (28 \%) og 'Ydelse af den nødvendige omsorg' (25\%). Prioriteringer af botilbuddenes to vigtigste opgaver, som føjer sig direkte ind i servicelovens to 'ben', hvad angår indsatsen for hjælp- og støttetrængende borgere; nemlig på den ene side at bidrage til borgerens individuelle udvikling med respekt for borgerens integritet, og på den anden side at træde til og yde den omsorg og pleje, borgeren vurderes at have behov for.

En indikator på, at servicelovens 'ånd' er blevet en integreret del af den socialpædagogiske faglige opgaveforståelse, der gør sig gældende blandt pædagoger og omsorgsmedhjælpere i botilbud for voksne med psykisk handicap; endda i en sådan grad, 
at omsorgsopgaven viger førstepladsen for målsætningen om at støtte den enkelte borger til udvikling af en positiv identitet og dermed understøtte individets oplevelse af at være en 'borger i udvikling' mod højere grad af selvstændighed og integritet. ${ }^{71}$

Svarfordelingen mellem de fire højest prioriterede delmål er dog relativ jævn, for den tredje højest prioriterede er at underst $\varnothing$ tte beboerens/brugerens 'mestringskompetence' med $22 \%$ svar i denne kategori. Mestringsbegrebet har tematisk slægtskab med 'identitetsbegrebet' og karakteriserede sammen med beslægtede begreb som 'empowerment' et af nøglebegreberne i den faglige opgaveforståelse i 1980'erne under eksempelvis 'Det Kan Nytte' projekterne, men har altså i undersøgelsen her måttet vige prioritet til den aktuelle velfærdspolitiske ideologi om borgeren som individ og 'herre i eget hus' snarere end som deltager i selvforvaltende fællesskaber.

Det fjerdehøjeste prioriterede delmål - kompenserende indsatser (18 \%) - har i modsætning til mestringsbegrebet aner tilbage til den 'klassiske' institutionsperiode med blandt andet systematisk ADL-træning som central socialpædagogisk omsorgsopgave, og således markerer Tabel 9 glidninger i prioriterede delmål med indsatsen i botilbud mv., der er i pagt med tidens tendenser inden for socialpolitik og socialpædagogik, med den tankevækkende lave prioritet, den femte og sidste valgmulighed - 'Skabelse af forståelse og rummelighed i det omgivende samfund' - indtager med prioritering fra blot $7 \%$ af de deltagende pædagoger og omsorgsmedhjælpere.

Den lave faglige prioritet som den samfundsmæssige dimension indtager, modereres muligvis, hvis der ses på forskelle i prioriteringer mellem forskellige medarbejdergrupper via en særkørsel af data opdelt på henholdsvis pædagoger og omsorgsmedhjælpere i københavnerunders $\emptyset$ gelsen, ledere i København og endelig den landsdækkende omsorgsmedhjælperundersøgelse.

Her ser prioriteringerne således ud:

\footnotetext{
${ }^{71}$ I 'Frigørelsens magt - pædagogiske roller i relation til frie, udviklingshæmmede voksne' (Hur 2009) er denne problematik udfoldet.
} 
Tabel 9s. Prioritering af delmål med indsatsen i bo- og dagtilbud

\begin{tabular}{|l|c|c|c|c|}
\hline $\begin{array}{l}\text { Prioritering af delmål med } \\
\text { indsatsen i bo- og dagtilbud }\end{array}$ & $\begin{array}{c}\text { Ledere i } \\
\text { Køben- } \\
\text { havn }\end{array}$ & $\begin{array}{c}\text { Pædago- } \\
\text { ger i Kø- } \\
\text { benhavn }\end{array}$ & $\begin{array}{c}\text { Omsorgs- } \\
\text { med- } \\
\text { hjælpere } \\
\text { i Køben- } \\
\text { havn }\end{array}$ & $\begin{array}{c}\text { Omsorgs- } \\
\text { med- } \\
\text { hjælpere } \\
\text { på lands- } \\
\text { plan }\end{array}$ \\
\hline Udvikling af en positiv identitet & 1 & 1 & 1 & 2 \\
\hline $\begin{array}{l}\text { Ydelse af den nødvendige om- } \\
\text { sorg }\end{array}$ & 3 & 3 & 2 & 1 \\
\hline $\begin{array}{l}\text { Mestring af aktiv livsudfoldelse } \\
\text { i samspil med andre }\end{array}$ & 2 & 2 & 4 & 3 \\
\hline $\begin{array}{l}\text { Opøvelse af færdigheder, som } \\
\text { kan kompensere for den ned- } \\
\text { satte funktionsevne }\end{array}$ & 4 & 4 & 3 & 4 \\
\hline $\begin{array}{l}\text { Skabelse af forståelse og rum- } \\
\text { melighed i det omgivende sam- } \\
\text { fund }\end{array}$ & 5 & 5 & 5 & 5 \\
\hline
\end{tabular}

Svarfordelingerne rykker ikke markant ved det billede, der tegnes i foregående tabel, men der er dog interessante forskelle, når der ses på variationer mellem de deltagende grupperinger.

Først og fremmest, at omsorgsmedhjælperne på landsplan som den eneste gruppering har den grundlæggende omsorgsopgave som højeste prioritet, mens såvel ledere som pædagoger i København placerer den som tredjeprioritet (sammenlignet med forrige tabel er mestringsperspektivet rykket op som anden prioritet), og da det 'klassiske' kompenserende perspektiv for omsorgsmedhjælpere i København er prioriteret en tak højere end de $\varnothing$ vrige grupperinger, giver det samlet et tendensbillede af, at pædagoger og ledere især vurderer den individuelle positive identitetsdannelse, 'borgerudviklingsstøtte' og mestringstematikken højest, mens omsorgsmedhjælperne som helhed er mere 'rodfæstede' i socialpædagogiske grundlæggende omsorgsforståelse og kompenserende træningstilgange, når de vigtigste elementer i indsatsen for og med beboerne/borgerne skal karakteriseres.

Én vurdering af vigtigste delmål i indsatsen på tværs af grupperingerne er der dog enighed om. Alle grupperinger har "Skabelse af forståelse og rummelighed i det omgivende samfund" som lavest prioriterede delmål, og for alles vedkommende med en relativ stor procentmargin op til de fire $\emptyset$ vrige svarkategorier.

Den radikale handicappolitiske agenda om $n \varnothing d v e n d i g h e d e n$ at arbejde for et inkluderende samfund, hvor fokus ikke i så høj grad er de handicappedes normaliserede selvhjulpenhed, men samfundets villighed til at indrette sig, så der er plads til og respekt for alle borgere uanset handicap eller andre funktionsvanskeligheder, er i dag ikke højt prioriteret, hvis det vurderes ud fra svarmønstre fra pædagoger, omsorgsmedhjælpere og ledere i botilbud. En simpel forklaring kan være, at der via spørgeskemaet først og fremmest er spurgt ind til dagligdagen $i$ botilbud og arbejdsopgaver- 
ne her, men - på den anden side - kunne netop tendensen til 'privatisering' af boligen for voksne med psykisk handicap og ønsket om at skabe boliger og bomiljøer integreret i det pulserende nærmiljø, som ligger i tidens socialpolitiske paroler, afspejles i en $\emptyset$ get professionsfaglig interesse for at prioritere aktiv påvirkning af lokalmiljøet rundt om botilbuddene og i bredere perspektiv den samfundsmæssige parathed til at inkludere eller i det mindste rumme borgere med handicap i så høj grad som muligt.

Et sådant fagprofessionelt fokus vil ikke være ude af trit med tidens tendenser, hverken den nationale inklusionsideologi eller de internationale 'policy-papers' på området, hvoraf Danmark så sent som i maj 2009 ratificerede den seneste inden for feltet, 'FN's konvention om rettigheder for personer med handicap', som indleder den følgende afslutning. 


\section{Afslutning}

I maj 2009 ratificerede et enigt dansk Folketing 'FN's konvention om rettigheder for personer med handicap' oprindeligt formuleret i 2006. Heri kan læses i Artikel 19:

\section{"Artikel 19. Retten til et selvstændigt liv og til at være inkluderet i samfundet}

Deltagerstaterne anerkender, at alle personer med handicap har lige ret til at leve $i$ samfundet med samme valgmuligheder som andre, og skal træffe effektive og passende foranstaltninger til at gøre det lettere for personer med handicap fuldt ud at nyde denne rettighed samt fuldt ud at blive inkluderet og deltage i samfundet, herunder ved at sikre:

a) at personer med handicap har mulighed for at vælge deres bopæl, samt hvor og med hvem de vil bo, på lige fod med andre og ikke er forpligtet til at leve i en bestemt boform,

b) at personer med handicap har adgang til et udvalg af støttetilbud $i$ hjemmet og på boligområdet samt andre lokale støttetilbud, herunder den nødvendige personlige bistand for at kunne leve og være inkluderet i samfundet samt for at forebygge isolation fra eller udskillelse af samfundet,

c) at samfundets tilbud og faciliteter til den almene befolkning er tilgængelige for personer med handicap på lige fod med andre og tager hensyn til deres behov."

(FN's konvention om rettigheder for personer med handicap, 2009).

'Lov om social service' er - med hensyn til synet på psykisk handicappede borgere og deres bo-rettigheder - ideologisk og politisk meget tæt på de standarder, FN konventionen forpligtiger de ratificerende lande på.

Men resultater fra unders $\varnothing$ gelsen blandt medarbejdere i botilbud bestyrker indtrykket af, at vi i Danmark i praksis er langt fra at realisere FN Konventionens artikel 19, stk. a). Der er 'på papiret' frit boligvalg for voksne psykisk handicappede, men i realiteternes verden er valgmulighederne små, når de vurderes af professionelle inden for området. Spørgeskemadeltagernes vurdering af beboernes "indflydelse på, hvor de bor og hvem de bor sammen med" er ubetinget det spørgsmål, hvor der er flest svar i 'den negative ende', idet tre fjerdedele af alle svar er i kategorierne 'lav' eller 'meget lav', og hvor 'meget lav' alene repræsenterer over halvdelen af alle svarene.

Men dette svarmønster må - når der ses ud over samtlige svarfordelinger, der angår vurderinger af, hvordan botilbuddet i det daglige løser de pædagogiske udviklings- og omsorgsopgaver - betragtes som undtagelsen.

Et indtryk, der dannede sig undervejs i gennemgang og tolkning af de mange og varierende spørgsmål, som kredser om synspunkter på 'den gode indsats', erfaringer 
med beboere, kolleger og ledelse, vurderinger af botilbuddenes pædagogiske kultur og det psykiske og fysiske arbejdsmiljø, kan benævnes 'trefjerdedels-tendensen'.

De forskellige typer af sådanne spørgsmål er typisk bygget op med en skala fra positiv til negativ - 'helt enig - helt uenig' eller 'i høj grad - slet ikke' eller 'meget høj - meget lav' osv. - og et helhedsindtryk er, at der typisk i mange svarfordelinger er op mod tre fjerdedele i 'den positive ende', og en fjerdedel i den 'negative ende'. Med en del undtagelser, naturligvis, og typisk med mange af de positive vurderinger markeret som meget positive, mens det er en lille del af de negative vurderinger, der er meget negative.

Svarfordelingerne på et af undersøgelsens centrale spørgsmål, nemlig medarbejdernes sammenfattende vurdering af belastninger $\mathrm{i}$ arbejdet er et eksempel herpå, idet andelen, der markerer at de oplever arbejdet "Noget eller meget psykisk belastende", er $27 \%$ (og tilsvarende $25 \%$ i forbindelse med fysisk belastende), mens tre fjerdedele svarer 'Nej, ikke eller kun lidt' til henholdsvis psykisk og fysisk belastende.

Hvilken konklusion, der kan drages af svarfordelinger som ovennævnte, afhænger af synsvinklen.

På den ene side kan med vægt fremhæves, at en fjerdedel af en medarbejderstab, der oplever det daglige arbejde som 'noget eller meget' psykisk og fysisk belastende er mange, og her især hvis det tilføjes, at tilfredshedsundersøgelser ofte falder relativt positivt ud.

På den anden side giver svarfordelingen ikke et generelt indtryk af en medarbejdergruppe under massivt pres ift. deres pædagogiske arbejde inden for et område, der som nævnt flere gange har været under pres af såvel medier som politikere og kommunalforvaltningerne. Denne konklusion underst $\varnothing$ ttes endvidere af svarmønstrene på det overordnede spørgsmål om de deltagende pædagoger og omsorgsmedhjælpere 'alt i alt' er tilfredse med deres nuværende arbejde. $63 \%$ svarer 'ja, i høj grad' i forhold til det daglige arbejde med beboerne, 30 \% 'i nogen grad' og kun $7 \%$ markerer her svar under en af de to mulige 'nej-kategorier'. Helt så positiv er svarfordelingen i forhold til arbejdsbetingelserne dog ikke (36 \% i høj grad og $46 \%$ i nogen grad), og det er en lille femtedel - $18 \%$ - der er på 'negativsiden'.

Hertil kan lægges billedet af, at der ikke kan spores tendenser til en massiv flugt fra arbejdsområdet bo- og dagtilbud for voksne psykisk handicappede. Tre fjerdedele af pædagogerne forventer at arbejde samme sted eller i et tilsvarende bo- og dagtilbud om tre år (mod halvdelen af omsorgsmedhjælperne), og da spørgerunden gennemførtes $f \varnothing r$ arbejdsløsheden som følge af krisetendenser i samfundet viste stigende tendens, kan en mulig forklaring ikke findes i forventninger om, at det ville være vanskeligt at finde job i andre erhverv. 
Udfoldes nogle af indtrykkene fra spørgeskemaunders $\varnothing$ gelsen, kan der sammenfattende peges på følgende.

Selvom det overordnede indtryk af oplevelse af belastninger i arbejdet som nævnt følger 'trefjerdedels-tendensen', viser der sig på detailspørgsmål om arbejdsmiljø, trivsel og arbejdsmæssige belastninger nogle sider, der opleves mere belastende end andre.

Blandt psykiske belastninger vejer især 'mængden af arbejdsopgaver pr. dag' og 'egne høje krav til arbejdspræstation' tungt, idet et flertal af medarbejderne her er på 'negativsiden' ('i nogen eller høj grad', henholdsvis 55 \% og 56 \%), men også psykiske belastninger som oplevelse af 'stort ansvar' og at skulle tage 'vigtige beslutninger under tidspres' er blandt de mere markante psykiske belastninger ${ }^{72}$.

Ses der på fysisk belastende gener i arbejdet er det især forstyrrende lyde/megen st $\varnothing$, tunge løft/belastende arbejdsstillinger og for små arbejdslokaler, der opleves at forekomme i generende grad, idet seks ud af ti medarbejdere svarer 'ja' hertil ${ }^{73}$.

Oplevelsen af psykisk belastende situationer kan også spores i det daglige pædagogiske arbejde med beboerne.

Mere end halvdelen af medarbejderne oplever, at konflikter med beboerne eller optræk til konflikter beboerne imellem er 'ofte' eller 'meget ofte' forekommende, og lidt under halvdelen oplever urolige eller voldsomme beboere i 'nogen' eller 'høj' grad som en psykisk belastende del af det daglige arbejde, mens det er en fjerdedel, der $\mathrm{i}$ 'nogen' eller 'høj' grad oplever at 'være udsat for vold' som en psykisk belastende del af arbejdet.

Alligevel er det generelle billede, at svarmønstrene på de mange andre spørgsmål vedrørende det pædagogiske arbejde i botilbuddene efterlader indtrykket af en generel positiv stemning omkring det daglige arbejde for langt hovedparten af de deltagende pædagoger og omsorgsmedhjælpere. En del af 'myterne' omkring vanskelige beboere og problemfyldte spisesituationer, modvilje mod praktisk hjælp og støtte i den daglige hygiejneomsorg, krævende pårørende, mv., kan ikke genfindes i svarmønstrene, når der ses efter det store flertals vurderinger, og et fåtal (3 \%) oplever 'i høj grad' den praktiske omsorg vanskelig mod - i den anden ende - $69 \%$, der her svarer 'slet ikke' eller kun 'i mindre grad' vanskeligt.

\footnotetext{
${ }^{72}$ Generelt er der ikke store forskelle i svarmønstre mellem pædagoger og omsorgsmedhjælpere undervejs i spørgeskemasvarene, men 'mængden af opgaver' og at skulle træffe 'vigtige beslutninger under tidspres' er to spørgsmål, hvor der er betydeligt flere omsorgsmedhjælpere end pædagoger, der svarer 'slet ikke' belastende.

${ }^{73}$ Ses der efter forskelle mellem omsorgsmedhjælpere og pædagoger ift. oplevelse af generende fysiske gener i det daglige arbejde, ligger pædagogerne her generelt lidt højere på 'ja-siden', bortset fra på spørgsmålet om tunge løft og belastende arbejdsstillinger, hvor omsorgsmedhjælperne i højere grad svarer 'ja' hertil.
} 
Her spiller det ind, at hele 72 \% - på trods af at flere end halvdelen af medarbejderne oplever for mange arbejdsopgaver i det daglige - svarer 'helt enig' eller 'delvist enig' til, at der "i almindelighed er der den nødvendige tid til den daglige omsorg i forhold til de enkelte beboere/brugere", en endnu større andel (86 \%) svarer ligesådan på spørgsmålet om, hvorvidt der "På bostedet/afdelingen tages ... tilstrækkeligt hensyn til de enkelte beboeres/brugeres individuelle livsrytmer og daglige rutiner."

Og når pædagoger og omsorgsmedhjælpere skal vurdere er billedet, at beboerne generelt opleves tilfredse i dagligdagen og i øvrigt glade for det dagtilbud, de fleste er tilknyttet. Med den tilføjelse, at beboerne synes, der burde være flere aktiviteter som byture, udflugter mv. ud af huset.

Trods ovennævnte indtryk af en dagligdag, der i mange af de praktiske pædagogiske og omsorgsrettede opgaver vurderes ikke at være massivt vanskelig eller belastende, er spørgsmålet om oplevelsen af etiske dilemmaer i dagligdagen et af dem, der høster mange 'ja-svar'.

$40 \%$ af medarbejderne er 'helt enige' i at de " $i$ dagligdagen ofte oplever ... 'etiske dilemmaer' mellem forskellige pædagogiske hensyn ift. den enkelte beboer/bruger (f.eks. beboer/brugers krav om 'usund mad' og pædagogisk omsorgspligt)", og sammen med de 'delvist enige' er det $85 \%$ af den samlede medarbejdergruppe, der her nikker bekræftende, mod 15 \% på 'uenig-siden'. Et bekræftelse på en af de professionsproblematikker ansatte i bo- og dagtilbud har ind på livet i dagligdagen, og som er blevet mere markant (på godt og ondt) med den måde, det dobbelte krav om såvel støtte til beboernes personlige udvikling som varetagelsen af en basal omsorgspligt er udmøntet i 'Lov om social service'.

I svarmønstrene på dette spørgsmål om oplevelsen af etiske dilemmaer, kan dog iagttages nogle interessante variationer, når der ses efter forskelle mellem medarbejdergrupperne og bostedstypen.

Først og fremmest er der en markant større andel omsorgsmedhjælpere (23\%), der er 'uenig' eller 'helt uenig' sammenlignet med pædagoggruppen (12\%). Næsten dobbelt så mange (i procent) omsorgsmedhjælpere kan således ikke nikke genkendende til, at der ofte forekommer 'etiske dilemmaer' i det daglige arbejde. Det kan skyldes en anden opgaveprofil, eller at det er et af de områder, hvor den pædagogiske faglige professionsforståelse er forskellig mellem pædagogiske uddannede og ikkeuddannede. En mulig tolkning, der bestyrkes ved, at andelen af 'ved ikke' svar blandt omsorgsmedhjælperne er $17 \%$ (mod $4 \%$ blandt pædagogerne).

En anden forskel i svarmønstre er variationer mellem de typisk lidt større botilbud sammenlignet med de mindre bofællesskaber. Her er der er stor forskel på andelen, der er 'helt enige'. 59 \% i bofællesskaber mv. er 'helt enige' i, at de ofte står med 'etiske dilemmaer', mod $42 \%$ blandt personalet i botilbud, og i den anden ende af skalaen er $20 \%$ fra botilbud, der er 'uenig eller helt uenig' mod kun $3 \%$ fra bofællesskaber mv. 
Et bud på en mulig forklaring på disse forskelle kan være en højere grad af regelstyret 'institutionaliseret dagligdag' i de typisk lidt større botilbud, som ikke kræver så mange ad hoc beslutninger med flere mulige valg at træffe i situationen, som kan indebære etiske dilemmaer.

At flere pædagoger end omsorgsmedhjælpere mener, at de står over for 'etiske dilemmaer' $\mathrm{i}$ det daglige arbejde kan indikere en højere grad af oplevelse af medansvar $\boldsymbol{i}$ den daglige planlægning og opgaveløsning, og det er et af de få andre områder, hvor der viser sig større forskelle de to medarbejdsgrupper imellem.

På et spørgsmål som "I hvilket omfang har du medansvar for planlægning i forhold til beboere/brugere", er der på delspørgsmålet "I forhold til den daglige omsorg" nok et flertal - $59 \%$ - af omsorgsmedhjælperne, der svarer 'i høj grad', men det er hele 25 \% færre (i antal) end pædagogerne, hvor 85 \% svarer således, og på fire ud af de fem delspørgsmål, der direkte angår medansvar for planlægningen, er procentdelen af pædagoger, der svarer 'i høj grad' 20-30 \% højere end for omsorgsmedhjælperne.

Spørgsmål om oplevelse af direkte medansvar i den daglige planlægning fører over i bredere spørgsmål om medarbejdernes oplevelse af ledelse og organisation af det bosted, de er ansat.

Et beskedent antal medarbejdere - mellem $2 \%$ og $8 \%$ - markerer, at de 'i høj grad' er utilfredse med måden botilbuddet er organiseret, mens flertallet 'slet ikke' mener at stedet ledes uprofessionelt (57 \%), eller at der er for langt fra 'gulv til ledelse' (51 \%), eller at der er for lidt uddelegering af ansvar, som hele $71 \%$ svarer 'slet ikke' til.

Kun i to ud af de fem spørgsmål er andelen af helt tilfredse medarbejdere (altså dem, der 'slet ikke' oplever problemer) under 50 \%, nemlig i spørgsmålet om hvorvidt bostedet kunne organiseres bedre med hensyn til strukturering af afdelinger mv., og i forbindelse med måden, nye medarbejdere introduceres til bostedet.

At der generelt er positiv stemning i forhold til ledelse og organisation på arbejdspladsen fører over i det afsluttende uddrag af de mange sider af socialpædagogik i botilbud for voksne handicappede, som har været trukket frem på de foregående mere end 100 sider: Hvad mener medarbejderne først og fremmest bør prioriteres i pædagogisk og organisatorisk udviklingsarbejde i bo- og dagtilbud?

Her konstrueredes en liste med seks forskellige valgmuligheder byggende på anbefalingerne fra arbejdsgruppen bag 'Veje til et godt liv i egen bolig ${ }^{74}$, der er omtalt flere gange i det foregående, og de udviklingsplaner, Socialudvalget i Københavns Kommune i et notat barslede med i $2007^{75}$.

\footnotetext{
${ }^{74}$ Socialministeriet 2007

${ }^{75}$ Socialudvalget 2007.
} 
Spørges på dette grundlag medarbejdere med pædagogiske opgaver i bo- og dagtilbud, er svaret klart: Fokus på faglighed, kompetenceudvikling og efteruddannelse blandt medarbejderne, og pædagogisk udviklingsarbejde med fokus på holdninger og værdier er så klart det vigtigste.

Hele 76 \% (tre fjerdedele) af svarkrydserne er sat i disse to valgmuligheder, mens de $\emptyset$ vrige fire valgmuligheder - 'Rekruttering og introduktion', 'Arbejdets organisering', 'Bruger- og pårørendeinddragelse' og 'Ledelsesudvikling' - må deles om de resterende $24 \%$ med ledelsesudvikling på allersidste pladsen med $5 \%$ af samtlige svar.

Her kan suppleres med en anden type prioritering, nemlig hvad der så anses for vigtigste delmål i den konkrete pædagogiske indsats for og med beboerne i botilbuddene.

Her er svarfordelingen på fem forskellige muligheder, der er formuleret med afsæt i vejledningen til Serviceloven, knap så entydig som ovenfor, men dog klar: De to højest prioriterede delmål er 'Udvikling af en positiv identitet' (28 \%) og 'Ydelse af den nødvendige omsorg' $(25 \%)^{76}$.

Prioriteringer af botilbuddenes to vigtigste opgaver, der føjer sig direkte ind i Servicelovens to 'ben', hvad angår indsatsen for hjælp- og støttetrængende borgere; nemlig på den ene side at bidrage til borgerens individuelle udvikling med respekt for borgerens integritet, og på den anden side at træde til og yde den omsorg og pleje, borgeren vurderes at have behov for.

En indikation på, at Servicelovens 'ånd' er blevet en integreret del af den socialpædagogiske faglige opgaveforståelse, der gør sig gældende blandt pædagoger og omsorgsmedhjælpere i botilbud for voksne med psykisk handicap; endda i en sådan grad, at omsorgsopgaven viger førstepladsen for målsætningen om at støtte den enkelte borgers opbygning af en positiv identitet og dermed understøtte individets oplevelse af at være en 'borger i udvikling' mod højere grad af selvstændighed og integritet.

En lang række andre facetter og detaljer fra det righoldige materiale i svarmønstrene fra spørgeskemaundersøgelsen kunne være trukket frem i afslutningen, og andre, der ser på de mange data, vil måske drage andre konklusioner end det overvejende positive indtryk, der her er søgt formidlet. Det afhænger som nævnt af den vinkel, der lægges ned over indkomne data, og ikke mindst af, hvorvidt - billedligt talt - en fjerdedel tolkes som 'alt for mange' eller som 'ikke så mange'.

Indledningsvist rejstes spørgsmålet om "det i praksis har været vanskeligt at ændre tilbudenes karakter, herunder personalets ... grundlæggende opfattelse af botilbud som

\footnotetext{
${ }^{76}$ Svarfordelingen mellem de $\varnothing$ vrige tre valgmuligheder er 'Mestring af aktiv livsudfoldelse i samspil med andre' (22 \%), 'Opøvelse af færdigheder, som kan kompensere for den nedsatte funktionsevne' (18\%) og endelig 'Skabelse af forståelse og rummelighed i det omgivende samfund' (7\%).
} 
institutioner" i de ti år, 'Lov om social service' har været det juridiske grundlag for socialpædagogik i botilbud til voksne med varig nedsat psykisk funktionsevne.

Et spørgsmål, det ikke er muligt at svare entydigt på. Som det fremgik af kapitel 1's dokumentanalyser har der kunnet iagttages udviklinger inden for området i retning af 'afinstitutionalisering', og mange svarm ønstre fra spørgeskemaunders $\varnothing$ gelsen peger sammen med det antropologiske blik ind i et bo- og dagtilbud i kapitel 4 - på en dagligdag i botilbud, der ikke af det pædagogiske personale beskrives som 'institutionaliseret' eller karakteriseres som en 'teknisk rutinepræget' dagligdag.

Formålet med undersøgelsen har heller ikke været at dykke ned i bestemte problemstillinger eller snævre undersøgelsesspørgsmål. I stedet har ambitionen været at pejle væsentlige sider af dagligdagen og den praktiserede socialpædagogik i botilbud, og hermed tilvejebringe en konkret vidensfond til inspiration for fagligt udviklingsarbejde $i$ de kommende år.

245 medarbejdere og 15 ledere fra Københavns Kommune har deltaget i spørgeskemaunders $\varnothing$ gelsen. Et relativt stort antal, men i sig selv ikke i strikte forstand repræsentativt for ansatte inden for området på landsplan - eller det kan i hvert fald ikke verificeres, idet der er forbløffende få 'nagelfaste' statistiske opgørelser over antal ansatte og inden for hvilke faggrupper, så der er ikke noget solidt at sammenligne med.

Der peges i undersøgelsens dataanalyse ${ }^{77}$ på en sandsynlig overvægt af yngre medarbejdere og med lidt flere mænd end på landsplan som helhed, men under alle omstændigheder er mange af spørgsmålene af typen vurderinger, holdninger og synspunkter, og de har i sig selv tyngde med deres 'kvalitative' islæt. Og tankevækkende er, at sammenligninger med den parallelundersøgelse, der er foretaget blandt et udsnit omsorgsmedhjælpere på landsplan med deltagelse af relativt flere kvinder i en højere alder end $\mathrm{i}$ 'Københavnerundersøgelsen'78 $\mathrm{i}$ overraskende mange af spørgsmålene kommer med svarfordelinger, der næsten på procentniveau er identiske med dem, der er præsenteret i rapporten her.

\footnotetext{
77 Jf. bilag 1.

${ }^{78}$ Robenhagen, Langager, Højmark og Allerup 2009.
} 


\section{Referencer $^{79}$}

Allerup, P., S. Langager og O. Robenhagen (2004). Sfo under forandring - samordning med skolen, pædagogiske funktioner og pædagogmedhjælpernes opgaver. Danmarks Pædagogiske Universitets Forlag.

Bengtsson, S. (2008). Handicap og samfundsdeltagelse 2006. SFI ${ }^{80}$.

Bryderup, I. M., S. Langager og O. Robenhagen (2000). Pædagogmedhjæ/pernes arbejde i daginstitutioner for 0-6 årige. København. Danmarks Pædagogiske Institut.

Center for kvalitetsudvikling (2008): De pårørende har ordet. Landsdækkende pårørendeundersøgelse på boformer for voksne personer med handicap. Landsrapport. ${ }^{81}$

CLH (Center for Ligebehandling af Handicappede) (2008): Fakta om botilbud ${ }^{82}$

Cochran, W. G. (1977). Sampling techniques. New York: John Wiley.

COWI A/S \& Socialt Udviklingscenter SUS (2002): Evaluering af erfaringer med institutionsbegrebets ophævelse på handicap-området 1998-2002. Socialministeriet. ${ }^{83}$

Etikos APS (2007): Det gode liv i egen bolig. Velfærdsministeriet. ${ }^{84}$

FN's konvention om rettigheder for personer med handicap (2009). ${ }^{85}$

Hastrup, K. (2003). Metoden Opmærksomhedens retning. I: Hastrup, K (red.): Ind i verden. En grundbog i antropologisk metode. København. Hans Reitzels Forlag

Hur, S.M. (2009). Frigørelsens magt - pædagogiske roller i relation til frie, udviklingshæmmede voksne. Danmarks Pædagogiske Universitetsskole, Aarhus Universitet ${ }^{86}$.

Højmark. A. (2009). Om tilsætning og opfindsomhed - en pædagogisk antropologisk undersøgelse om begrundelser $i$ socialpædagogisk arbejde med voksne med udvik-

\footnotetext{
79 De angivne web-adresser er sidst lokaliseret den 16. august 2009, og enkelte kan derfor være slettet/flyttet efter den dato.

${ }^{80}$ www.sfi.dk/Default.aspx?ID=4681\&Action=1\&Newsld $=1161$

${ }^{81}$ http://www.regionmidtjylland.dk/psykiatri+og+social/brugere+og+p\%C3\%A5r\%C3\%B8rende/p\%C3\%A

5r\%C3\%B8rende-unders\%C3\%B8gelser/de+p\%C3\%A5r\%C3\%B8rende+har+ordet

${ }^{82}$ http://www.clh.dk/index.php?id=1437

83 http://www.sus.dk/files/publikationer/evaluering\%20socialministeriet.PDF

${ }^{84}$ http://www.ism.dk/data/Lists/Publikationer/Attachments/69/Det\%20gode\%20liv\%20i\%20egen\%20boli g.pdf

${ }^{85}$ http://www.ism.dk/Temaer/sociale-omraader/Handicap/handicappolitik/FNshandicapkonvention/Sider/Start.aspx

${ }^{86}$ www.dpu.dk/ssip/ebog
} 
lingshæmning i botilbud. Danmarks Pædagogiske Universitetsskole, Aarhus Universitet. $^{87}$

Indenrigs- og Socialministeriet (2009). Kompetenceudvikling i botilbud. ${ }^{88}$

Kayser, S. (2005). På den anden side - etik, dilemmaer og omsorg. UFC Handicap. ${ }^{89}$

Kofod, K. K. og N. R. Jensen (2009). Organisationsudvikling og socialpædagogisk praksis i bo- og dagtilbud for voksne udviklingshæmmede. Danmarks Pædagogiske Universitetsskole, Aarhus Universitet ${ }^{90}$.

Københavns Kommune (2007). Foreløbig redegørelse for pressesager på handicapområdet ifm dokumentarprogrammet "Er du 'åndssvag'?". Notat 20. februar 2007. Københavns Kommune, Socialforvaltningen.

Københavns Kommune (2005). Statistisk redegørelse om ansatte i Københavns Kommune med anden etnisk baggrund end dansk. Københavns Kommune, Økonomiforvaltningen.

Lov om social service. (LBK nr. 1117) (2007). Velfærdsministeriet.

Marcus, G. E. (1998). The Uses of Complicity in the changing Mise-en-Scéne of Anthropological fieldwork. In: Ethnography through thick and thin. Princeton University Press

Nirás Konsulenterne (/Københavns Kommune) (2008): Undersøgelse af bosteder og bofællesskaber i Københavns Kommune.

Nyt fra Danmarks statistik (2009). Emnegruppe: Befolkning og valg. Nr. 68/2009

PLS Rambøll Management (2001): \$111-planer - et godt redskab i indsatsen over for voksne med nedsat funktionsevne? København. Socialministeriet.

Politikens Nudansk Ordbog (1999). 17. udgave.

Robenhagen, O., S. Langager, A. Højmark og P. Allerup (2009). Den daglige forskel omsorgsmedhjælpere i bo- og dagtilbud for voksne med varig nedsat fysisk eller psykisk funktionsevne. Danmarks Pædagogiske Universitetsskole, Aarhus Universitet ${ }^{91}$.

Socialministeriet (2003): Et liv så tæt på det almindelige som muligt. Sammenfatning af resultater fra Socialministeriets evalueringsprogram . ${ }^{92}$

\footnotetext{
${ }^{87}$ www.dpu.dk/ssip/ebog

${ }^{88} \mathrm{http}: / /$ www.ism.dk/Puljer/sociale-omraader/handicap/stibo/Sider/Start.aspx

${ }^{89} \mathrm{http}: / /$ www.servicestyrelsen.dk/default.asp?id=149285\&sshow=1\&itemid $=146946$

90 www.dpu.dk/ssip/ebog

91 www.dpu.dk/ssip/ebog

${ }^{92}$ http://www.ism.dk/data/Lists/Publikationer/Attachments/68/Veje\%20til\%20et\%20godt\%20liv\%20i\%20 egen\%20bolig.pdf
} 
Socialministeriet (2007): Veje til et godt liv i egen bolig. Fokus på etik, værdigrundlag og kompetenceudvikling i botilbud for mennesker med handicap og sindslidelser m.fl. ${ }^{93}$

Socialpædagogerne (2009): Utidssvarende boliger - en undersøgelse af botilbud til voksne mennesker med handicap. ${ }^{94}$

Socialudvalget (2007). Dagsorden for ordinært møde onsdag den 7. marts 2007, Bilag 1. Københavns Kommune.

Videnscenter For Autisme. ${ }^{95}$ Se web-adresse.

Wadel, C. (1991). Feltarbeid i egen kultur. Flekkefjord: Seek.

\footnotetext{
${ }^{93} \mathrm{http}: / /$ www.servicestyrelsen.dk/default.asp?id=149283\&sshow=1\&itemid=146908

${ }_{94}$ http://www.sl.dk/upload/aktuelt/nyheder-\%20pdf-filer/2009/botilbudsunders\%c3\%b8gelsen.pdf

${ }^{95}$ www.autisme.dk
} 


\section{Bilag}

Bilag 1. Metoder og analyser i forbindelse med spørgeskemadataindsamlingen.

Bilag 2. Om det antropologiske feltstudie.

Bilag 3. Spørgeskemaunders $\varnothing$ gelsens data. 


\section{Bilag 1. Metoder og analyser $\mathrm{i}$ forbindelse med spørgeskema- dataindsamlingen ${ }^{96}$}

I det samlede projekt er der indsamlet data på to forskellige måder, afhængig af om der er tale om data til Københavnerunders $\varnothing$ gelsen eller til den landsdækkende undersøgelse.

I Københavnerundersøgelsen er der tale om en 'total- undersøgelse' i denne forstand at samtlige pædagoger og omsorgsmedhjælpere blev fors $\emptyset$ gt 'nået' via bostedernes ledere, som viderebragte spørgeskemaerne. Grundlaget for udsendelsen var en komplet liste over bosteder for psykisk/fysisk handicappede. Københavnerunders $\varnothing g e l-$ sen gennemførtes i september 2008, med en enkelt rykkerskrivelse til lederen.

I den landsdækkende unders $\varnothing$ gelse, som kun angår omsorgsmedhjælpere organiseret i FOA, blev FOA's register over medlemmer benyttet som grundlag for udsendelse af spørgeskemaer direkte til omsorgsmedhjælpere, som man ønskede svar fra. Undersøgelsen gennemførtes i april 2008, rutinemæssigt med en efterfølgende rykker.

Mens Københavnerunders $\varnothing$ gelsen i sit udgangspunkt, via den måde dataindsamlingen er konstrueret på, kan siges at leve op til krav om repræsentativitet, er det klart, at det metodiske grundlag for landsindsamlingen ikke fører til, at der opnås repræsentativitet.

I begge undersøgelser er der vished om, at ikke alle, der fik tilsendt et spørgeskema, har returneret det, og svarprocenten er således under alle omstændigheder mindre end $100 \%$.

I 'Københavnerunders $\varnothing$ gelsen' kan vi med en hvis sikkerhed beregne antallet af mulige respondenter ud fra bemandingsregistre fra de enkelte bosteder. En troværdig svarprocent kan derfor udregnes simpelt som forholdet mellem antallet af registrerede svar i forhold til dette beregnede tal. Det fører til en samlet svarprocent på 61 \%, idet 245 svar sættes i relation til 404 udsendte skemaer.

I den landsdækkende unders $\varnothing$ gelse er det ikke muligt ud fra FOA's medlemslister at fremkomme med pålidelige skøn over det samlede antal omsorgsmedhjælpere i landets bo/dagtilbud. Det er derfor ikke muligt at sætte antallet af udsendte skemaer i relation $i$ et antal mulige respondenter, der findes i landet som helhed. Desmindre er det muligt at undersøge om de medlemmer som FOA har på sine lister udgør et repræsentativt udsnit af samtlige omsorgsmedhjælpere inden for området: Bosteder for psykisk/fysisk handicappede. Holder man sig til antallet af udsendte skemaer, som er

\footnotetext{
${ }^{96}$ Bilag 1 dækker såvel den foreliggende undersøgelse af pædagoger og omsorgsmedhjælpere ansat i Københavns Kommune, som den landsdækkende unders $\varnothing$ gelse af omsorgsmedhjælpere.
} 
782 og sætter dette i relation til, at der er indkommet i alt 377 svar, bliver den umiddelbare svarprocent $48 \%$.

Antallet af udsendte lederskemaer i Københavnerunders $\varnothing$ gelsen er 22, svarende til det totale antal bosteder inden for området. Der kom 15 skemaer retur, hvilket giver en svarprocent på $68 \%$.

Uanset om den metode, der fører til udsendelsen af spørgeskemaerne muligg ør repræsentativitet eller ej, som det viser sig at være tilfældet mht. til pædagoger og omsorgsmedhjælpere i Københavnerunders $\varnothing$ gelsen i forhold til landsunders $\varnothing$ gelsen, så vil svarprocenter på niveauerne 61 \% og 48 \% automatisk medføre, at man via en såkaldt frafaldsanalyse undersøger kvaliteten af de indkomne svar. Har man fået et skævt udsnit af de udsendte skemaer retur? Er det fx hovedsageligt yngre kvinder fra små bosteder, der har returneret skemaerne? Det vil selvfølgelig påvirke gyldigheden af en generel påstand om nogle arbejdsforhold, hvis det viser sig, at arbejdsforhold er afhængige af køn og størrelsen af bostedet - som i dette scenario fx ville vise sig at være overrepræsenteret i de returnerede svar.

Formålet med spørgeskemaunders $\varnothing$ gelserne har i begge unders $\varnothing$ gelser været at skaffe en bredt dækkende oversigt over forhold i bosteder for psykisk/fysisk handicappede.

\section{Vurdering af repræsentativitet og anvendelighed af indsamlede data}

Når man skal vurdere anvendeligheden af de indsamlede data, kan man dels se på videnskabsteoretiske aspekter af de indsamlede informationer, dels nogle mere praktiske i relation til, hvad data skal bruges til. Hvad angår det første, dækkes dette af begreberne validitet, reliabilitet og generaliserbarhed, mens anvendeligheden, set fra et praktisk synspunkt bl.a. har at gøre med datas evne til at belyse forhold med acceptabel statistisk præcision.

Generaliserbarheden af resultater ud fra de indsamlede data afhænger af om data er repræsentative for de respondentgrupper, de er indsamlet fra. Det kunne være nærliggende at benytte ordet 'i hvor høj grad' i stedet for 'om' i den hensigt at måle repræsentativiteten på en skala med 'ikke repræsentativ' i den ene ende og 'helt repræsentativ' i den anden. Dette kan imidlertid ikke umiddelbart lade sig gøre, idet egenskaben 'at være repræsentativ' iflg. selve definitionen på begrebet afgøres med et 'ja' eller et 'nej'.

Repræsentativitet af en stikprøve afgøres alene ud fra den måde stikprøven er defineret (se fx Cochran 1977). 
I Københavnerundersøgelsen blev der anvendt en total sampling og ved den landsdækkende undersøgelse en slags tilfældige stikprøver, som tog afsæt i FOA's lister over medlemmer.

Der er imidlertid forskel på, hvorledes en stikprøve er planlagt - fx med henblik på at være repræsentativ - og de faktiske svar, som indsamlingen medfører. Hvis en stikprøver er planlagt som simpel tilfældig udvælgelse af fx 100 elementer, men det viser sig, at der alene opnås svar fra 40 kvinder, kan man næppe fæstne tillid til, at de 40 svar tegner et generelt billede af populationen. Dvs. generaliserbarheden ud fra de 40 svar er ikke mulig. Man kan, med en drejning af ordet 'repræsentativ' sige, at 'de 40 svar ikke er repræsentative for hele populationen'.

Det er vigtigt at skelne mellem på den ene side planlagte stikprøver, der via deres definitioner (som i hovedsagen simple tilfældige) er repræsentative og egenskaberne ved de indkomne faktiske svar. En del af begrundelsen for opståede misforståelser eller manglende forståelse på dette område, kan skyldes, at de faktisk indkomne svar ikke videnskabeligt set korrekt kan tilordnes egenskaben 'at være repræsentativ'. Det er, som anført en (teoretisk) egenskab ved den planlagte stikprøve, som ikke skal blandes sammen med empiriske iagttagelser af de faktisk indsamlede data. Forvekslingen sker, fordi repræsentative stikprøver ofte lykkes med at indsamle svar fra samtlige inviterede respondenter, altså opererer med en svarprocent på 100 \%. Derved indeholder de faktisk indkomne svar fordelinger på køn, alder, geografi osv. som approksimativt (altså med statistik usikkerhed) svarer til de sande fordelinger i populationen over for disse karakteristika. I dette tilfælde benytter vi sprogbrugen, at de indsamlede data er repræsentative.

Når en stikprøve ikke kan gennemføres med svar fra alle inviterede, altså med en svarprocent på mindre end $100 \%$, falder den afledte egenskab væk mht. til at fordele karakteristika som $k \varnothing n$, alder, geografi, institutionstype osv. approksimativt proportionalt som i hele populationen. I Københavnerundersøgelsen er svarprocenten $61 \%$ for pædagoger og omsorgsmedhjælpere, dvs. på mindre end 85 \% som er grænsen for, hvor man normalt går i gang med frafaldsanalyser. Ved den landsdækkende undersøgelse tillod selve metoden til udvælgelse ikke, at man kunne tale om repræsentativitet og blandt de faktisk udsendte skemaer kom kun $48 \%$ retur. Af flere grunde er der derfor et behov for at undersøge om de svar, der er til rådighed her, er 'dækkende' for gruppen som helhed, 'proportional' i den beskrevne forstand.

I tilfælde med lav svarprocent kan man, videnskabeligt set ikke tale om at de indsamlede data er repræsentative eller ej og man må benytte andre metoder til at beskrive datas evne til fx at 'repræsentere' de nævnte karakteristika. Når der nedenfor benyttes 
termen 'test for repræsentativitet' er det derfor lidt af en tilsnigelse, som, videnskabeligt set, måske burde kaldes 'test for proportionalitet' med reference til den afledte egenskab ved repræsentative stikprøver. Det er imidlertid praksis at kalde testene for 'test for repræsentativitet', og denne betegnelse vil derfor blive anvendt.

'Test for repræsentativitet/proportionalitet' gennemføres som antydet ved at se på fordelingen af visse karakteristika i de indsamlede data og sammenholde denne fordeling med den sande fordeling i populationen. For at dette skal kunne lade sig gøre, kræves det, at man faktisk kender den sande fordeling af sådanne karakteristika i hele populationen. Fx kræver en test for repræsentativitet mht. til $k \varnothing n$, at man kender den sande fordeling af de to $k \emptyset n$.

De statistiske analyser for proportionalitet, eller repræsentativitet, er gennemført ud fra fordelinger over eksterne variable som $k \emptyset n$, alder, bo/dagtilbuds størrelse, og for den landsdækkende undersøgelses vedkommende geografisk beliggenhed. Disse baggrundsvariable kan der skaffes information om. De skønnes samtidig at være relevante for at kunne tage stilling til spørgsmålet om repræsentativitet. Som det fremgår af diskussionen kan man ikke tilskrive de indsamlede data videnskabelige egenskaber om 'at være repræsentativ' overhovedet. Ligegyldigt hvor mange eksterne variable, man måtte anvende.

Afgørelsen af om testen fører til en de facto proportionalitet eller ej (altså 'repræsentativitet' eller ej) følger sædvanlig statistisk testteori med gennemførelsen af hypoteseprøvninger på et givet signifikansniveau.

Det kan i denne forbindelse være fristende at indføre en graduering a la 'mere' eller 'mindre' repræsentativ afhængig af om dette test gennemføres med store eller små pværdier (signifikanssandsynligheder). Dette er imidlertid i direkte modstrid med de grundlæggende egenskaber ved statistiske tests og er derfor undladt.

Det kan også være fristende at markere forskellige grader af 'repræsentativitet' afhængig af, om de statistiske tests for proportionalitet afvises over for alle eksterne kriterier eller om det alene er nogle få af de eksterne karakteristika, testene afvises over for.

Tilbage bliver en beregning omkring den statistiske usikkerhed, som kommer til udtryk $i$ beregning af konfidensgrænser omkring de estimater, der beregnes. Fx er det nemt at beregne $^{97}$ grænserne for hyppigheden blandt pædagoger og omsorgsmedhjælpere, som "ønsker at arbejde flere timer". Fra data ses det at 7.0\% af de afgivne 245 svar falder i kategorien svarer 'ja' til dette spørgsmål. Hvis resultatet er generaliserbart, er

\footnotetext{
${ }^{97}$ Benyt den hypergeometriske fordeling
} 
dette estimatet blandt pædagoger og omsorgsmedhjælpere i almindelighed i København. Man kan beregne at den 'sande' andel af pædagoger og omsorgsmedhjælpere, som "ønsker at arbejde flere timer" og finde, at den med $95 \%$ sikkerhed ligger i intervallet $7.0 \% \pm 3.2 \%$.

Anvendeligheden af de indsamlede data kan nu, i lys af ovenstående diskussion vurderes i forhold til fx konfidensgrænsernes bredde. Det ville være klart utilfredsstillende, hvis det første interval i stedet for $7.0 \% \pm 3.2 \%$. måtte beregnes fx til $7.0 \% \pm 6.0 \%$. I det sidste tilfælde, ville præcisionen formodentlig være for lav til at estimatet $7.0 \%$ havde praktisk værdi for efterfølgende analyser. Om det bør være $\pm 1 \%, \pm 2 \%$ eller \pm 4 $\%$ bestemmes i hovedsagen af antallet af indsamlede observationer.

\section{Opnåede svarprocenter og resultater af frafaldsanalyserne}

De indsamlede data i Københavnerunders $\varnothing$ gelsen og den landsdækkende unders $\varnothing$ gelse bliver underkastet de omtalte analyser af proportionalitet, dvs. frafaldsanalyser. De variable, der anvendes ved frafaldsanalyserne er $k \emptyset n$, alder, bostedst $\varnothing$ rrelse, og for den landsdækkende unders $\varnothing$ gelses vedkommende geografisk beliggenhed.

Overalt er der anvendt simple $\chi^{2}$ - tests for analyser af data i antalstabeller. Testene er gennemført på sædvanligt $5 \%$ signifikansniveau.

For den landsdækkende undersøgelse er det oplyst fra hvilket sted i Danmark det returnerede skema stammer. Det er derfor muligt at lave en frafaldsanalyse med baggrundsvariablen 'geografi', hvorunder de returnerede svars geografiske fordeling sammenholdes med den 'sande' fordeling af pædagoger og omsorgsmedhjælpere.

\begin{tabular}{|l|c|c|}
\hline Postnummer (grupperet) & Procent modtagne & Sand fordeling \\
\hline Region 1 & 12 & 92 \\
\hline Region 2 & 29 & 13 \\
\hline Region 3 & 15 & 22 \\
\hline Region 4 & 20 & 24 \\
\hline Region 5 & 24 & 100 \\
\hline Total & 100 & 9 \\
\hline
\end{tabular}

Tabel A. Svar opgjort pr. region (grupperede postnumre) fra returnerede skemaer fra omsorgsmedhjælpere samt fordeling af omsorgsmedhjælpere på landsplan.

De statistiske test for proportionalitet fører til en p-værdi på 0,15. Dermed 'godkender' testen stikprøvens fordeling mht. til geografi. 


\begin{tabular}{|l|c|c|c|c|c|c|}
\hline & \multicolumn{2}{|c|}{$\begin{array}{r}\text { Københavnerunders } \varnothing \text { gelsen } \\
\text { pædagoger }\end{array}$} & $\begin{array}{c}\text { Københavnerunders } \varnothing \text { gelsen } \\
\text { omsorgsmedhjælpere }\end{array}$ & \multicolumn{2}{|c|}{ Landsunders $\varnothing$ gelsen } \\
\hline Køn & $\begin{array}{c}\text { Procent } \\
\text { modtagne }\end{array}$ & $\begin{array}{c}\text { Sand } \\
\text { Fordeling }\end{array}$ & $\begin{array}{c}\text { Procent } \\
\text { modtagne }\end{array}$ & $\begin{array}{c}\text { Sand } \\
\text { fordeling }\end{array}$ & $\begin{array}{c}\text { Procent } \\
\text { modtagne }\end{array}$ & $\begin{array}{c}\text { Sand } \\
\text { fordeling }\end{array}$ \\
\hline Kvinder & 76 & 78 & 61 & 52 & 86 & \\
\hline Mænd & 24 & 22 & 39 & 48 & 14 & \\
\hline I alt & 100 & 100 & 100 & 100 & 100 & \\
\hline
\end{tabular}

Tabel B. Kønsfordeling af pædagoger og omsorgsmedhjælpere

Resultatet af testene for proportionalitet i tabel B mht. til $k \varnothing n$ er, at $p=0.43$ for København, pædagoger, $p=0.01$ for omsorgsmedhjælpere og for landsunders $\varnothing$ gelsen finder man $p=0.001$, hvis den sande fordeling på kvinder og mænd antages at være den samme (78 \%, 22 \%) som er gældende i København. For omsorgsmedhjælpere i København og for landsunders $\varnothing$ gelsen er der derfor nogle skævheder mht. til kønsfordelingen i de returnerede skemaer, som i København går ud på, at det især er kvinderne, der har returneret skemaerne. Noget tilsvarende skønnes at være tilfældet i landsundersøgelsen.

Gennemføres en samlet test (kun 'Københavnerundersøgelsen') for, om stikprøvens kønsfordeling er den samme som den sande fordeling, se tabel B1, resulterer dog i en accept ( $p=0.53)$; stikprøven kan derfor siges at genspejle korrekt kønsfordeling.

\begin{tabular}{|l|c|c|}
\hline \multirow{2}{*}{ Køn } & \multicolumn{2}{|c|}{ Københavnerunders $\varnothing$ gelsen } \\
\hline Kvinder & $\begin{array}{c}\text { Procent } \\
\text { modtagne }\end{array}$ & $\begin{array}{c}\text { Sand } \\
\text { fordeling }\end{array}$ \\
\hline Mænd & 72 & 70 \\
\hline I alt & 28 & 30 \\
\hline
\end{tabular}

Tabel B1. Kønsfordeling blandt medarbejdere i Københavns Kommune

Tabel $C$ viser aldersfordelingen for pædagoger og omsorgsmedhjælpere, som har returneret spørgeskemaet og den sande aldersfordeling for pædagoger og omsorgsmedhjælpere.

\footnotetext{
${ }^{98}$ Som reference for 'de sande fordelinger' i Københavns Kommune er anvendt en opgørelse lavet i 2007 (se Københavns Kommune 2007).
} 


\begin{tabular}{|l|c|c|c|c|c|c|}
\hline & \multicolumn{2}{|c|}{$\begin{array}{c}\text { Københavnerunders } \varnothing \text { gelsen } \\
\text { pædagoger }\end{array}$} & \multicolumn{2}{|c|}{$\begin{array}{c}\text { Københavnerunders } \varnothing \text { gelsen } \\
\text { omsorgsmedhiælpere }\end{array}$} & \multicolumn{2}{|c|}{ Landsunders $\varnothing$ gelsen } \\
\hline Aldersfordeling & $\begin{array}{c}\text { Procent } \\
\text { modtagne }\end{array}$ & $\begin{array}{c}\text { Sand } \\
\text { fordeling }\end{array}$ & $\begin{array}{c}\text { Procent } \\
\text { modtagne }\end{array}$ & $\begin{array}{c}\text { Sand } \\
\text { fordeling }\end{array}$ & $\begin{array}{c}\text { Procent } \\
\text { modtagne }\end{array}$ & $\begin{array}{c}\text { Sand } \\
\text { forde- } \\
\text { ling }^{100}\end{array}$ \\
\hline 29 år og yngre & 20 & 15 & 40 & 30 & 5 & 19 \\
\hline 30-39 år & 17 & 26 & 27 & 33 & 11 & 21 \\
\hline $40-49$ år & 25 & 30 & 27 & 23 & 32 & 28 \\
\hline 50-59 år & 30 & 26 & 6 & 12 & 32 & 26 \\
\hline 60 år og ældre & 8 & 3 & 0 & 2 & 10 & 6 \\
\hline I alt & 100 & 100 & 100 & 100 & 100 & 100 \\
\hline
\end{tabular}

Tabel C. Fordeling af alder for pædagoger og omsorgsmedhjælpere

Resultatet af testene for proportionalitet i tabel $\mathrm{C}$ mht. til alder er, at $p=0.001$ for $K \varnothing$ benhavn, pædagoger, $p=0.001$ for omsorgsmedhjælpere og for landsunders $\varnothing$ gelsen finder man også $p=0.001$.

En tilsvarende test med den samlede medarbejdergruppe (kun 'Københavnerundersøgelsen') for proportionalitet for den samlede aldersfordeling, se tabel C1, resulterer i afvisning af, at stikprøvens fordeling passer med den sande fordeling ( $p=0.001)$. Afvigelserne knytter sig især til en manglende returnering af skemaer fra 30-39 årige.

\begin{tabular}{|c|c|c|}
\hline \multirow[b]{2}{*}{ Aldersfordeling } & \multicolumn{2}{|c|}{$\begin{array}{c}\text { Københavnerunders } \varnothing \text { gelsen } \\
\text { Alle }\end{array}$} \\
\hline & $\begin{array}{l}\text { Procent } \\
\text { modtagne }\end{array}$ & $\begin{array}{c}\text { Sand } \\
\text { fordeling }\end{array}$ \\
\hline 29 år og yngre & 25 & 20 \\
\hline 30-39 år & 19 & 28 \\
\hline 40-49 år & 25 & 28 \\
\hline 50-59 år & 24 & 21 \\
\hline 60 år og ældre & 6 & 3 \\
\hline I alt & 100 & 100 \\
\hline
\end{tabular}

Tabel C1. Fordeling af alder i Københavns Kommune

I alle tre tilfælde afvises således, at stikprøverne er proportionale mht. til alder. I København er det især de unge, der har returneret skemaerne, mens det omvendte er tilfældet i landsunders $\varnothing$ gelsen.

\footnotetext{
99 Igen er anvendt opgørelsen lavet i 2007 (Københavns Kommune 2007).

${ }^{100}$ Der eksisterer ingen pålidelige statistiske opgørelser på landsplan, og den procentvise aldersfordeling, der her anvendes, er næppe anvendelig, idet den rummer såvel omsorgs- som pædagogmedhjælpere, og pædagogmedhjælpere er typisk en del yngre end omsorgsmedhjælpere (se Allerup, Langager og Robenhagen 2004 og Bryderup, Langager og Robenhagen 2000). Sammenligningen her udtrykker derfor først og fremmest sandsynligheden for, at der er en overrepræsentation af ældre medarbejdere inden for bo- og dagtilbud blandt FOA-organiserede omsorgsmedhjælpere. De tal, der ligger til grund for oversigtens 'sande fordeling' er fra 'Det fælleskommunale Løndatakontor' (www.fldnet.dk/).
} 


\section{Bo/dagtilbuddets størrelse}

Omfanget af retursvar kan afhænge af, om bo/dagtilbuddet er lille eller stor. For at unders $\varnothing$ ge dette nærmere viser tabel D en gruppering af bo/dagtilbudsst $\varnothing$ rrelsen i tre grupper.

En statistisk test viser, at fordelingen af antal beboere/brugere i Københavnerunders $\varnothing$ gelsen ikke afviger signifikant fra den sande fordeling, $p=0.83$; stikpr $\varnothing v e n$ er derfor hvad angår denne variabel 'repræsentativ' eller proportional i forhold til de faktiske forhold. I landsundersøgelsen har det ikke været muligt at fremskaffe pålidelige skøn over antallet af beboere/brugere pr bo/dagtilbud og analysen er derfor ikke gennemført.

\begin{tabular}{|c|c|c|c|c|}
\hline & \multicolumn{2}{|c|}{ Københavnerunders $\varnothing$ gelsen } & \multicolumn{2}{|c|}{ Landsunders $\varnothing$ gelse } \\
\hline $\begin{array}{l}\text { Bo/dagtilbuds st } \varnothing r- \\
\text { relse }\end{array}$ & $\begin{array}{c}\text { Procent } \\
\text { modtagne }\end{array}$ & $\begin{array}{c}\text { Sand } \\
\text { fordeling }\end{array}$ & $\begin{array}{c}\text { Procent } \\
\text { modtagne }\end{array}$ & Sand fordeling \\
\hline $\begin{array}{l}<10 \quad \text { beboe- } \\
\text { re/brugere }\end{array}$ & 0 & 12 & & \\
\hline $\begin{array}{l}10-29 \text { beboe- } \\
\text { re/brugere }\end{array}$ & 91 & 76 & & \\
\hline $\begin{array}{l}>\quad 30 \quad \text { beboe- } \\
\text { re/brugere }\end{array}$ & 10 & 12 & & \\
\hline I alt & 100 & 100 & & \\
\hline
\end{tabular}

Tabel D. Fordeling efter bo/dagtilbuddets størrelse målt ved antallet af klienter

\section{Konklusion}

Generelt set har dataindsamlingen vedrørende pædagoger og omsorgsmedhjælpere resulteret i lave svarprocenter, både for Københavnerundersøgelsen og for den landsdækkende unders $\varnothing$ gelse (kun omsorgsmedhjælpere). Fra ledere af bosteder i Københavnerundersøgelsen er en svarprocent på 68 \% tilfredsstillende og signalerer, at tallene fra denne gruppe umiddelbart kan benyttes til at tegne et troværdigt, repræsentativt billede af lederes forhold i København.

Vurderingen af om stikprøverne er sammensat på en måde, der svarer til virkeligheden er opsummeret i tabellerne E og $\mathrm{F}$, hvor resultaterne af tests for 'repræsentativitet' eller, rettere proportionalitet er vist over for nogle eksterne hovedvariable geografi, køn, alder og bostedstørrelse. 


\begin{tabular}{|l|c|c|c|}
\hline $\begin{array}{l}\text { Grundlag for vurdering af repræsentativi- } \\
\text { tet eller proportionalitet (p-værdier) }\end{array}$ & \multicolumn{2}{|c|}{$\begin{array}{c}\text { Københavner } \\
\text { undersøgelsen }\end{array}$} & $\begin{array}{c}\text { Københavner } \\
\text { unders } \varnothing \text { gelsen }\end{array}$ \\
\hline & Pædagoger & Omsorgsmhj. & Alle \\
\hline Geografi & & & + \\
\hline Køn & + & - & - \\
\hline Alder & - & - & + \\
\hline Bo/dagtilbuds størrelse & \multicolumn{2}{|c|}{+} & + \\
\hline
\end{tabular}

Tabel E: Oversigt over resultater af frafaldsanalyserne ' + ' markerer accept af tests for repræsentativitet, et '-' at testet resulterer i en signifikanssandsynlighed, som er mindre en 0.05 , altså forkastelse.

\begin{tabular}{|l|c|}
\hline $\begin{array}{l}\text { Grundlag for vurdering af repræsentativi- } \\
\text { tet eller proportionalitet (p-værdier) }\end{array}$ & Landsunders $ø$ gelsen \\
\hline & Omsorgsmedhjælpere \\
\hline Geografi & + \\
\hline Køn & - \\
\hline Alder & - \\
\hline Bo/dagtilbuds størrelse & \\
\hline
\end{tabular}

Tabel F. Oversigt over resultater af frafaldsanalyserne ' + ' markerer accept af tests for repræsentativitet, et '-' at testet resulterer i en signifikanssandsynlighed, som er mindre en 0.05 , altså forkastelse.

Det fremgår af tabel $\mathrm{E}$ og tabel $\mathrm{F}$, at der især er problemer med aldersfordelingen i stikprøven i forhold til, hvad den skulle være. Groft sagt er respondenterne i Københavnerundersøgelsen de unge, mens det i landsundersøgelsen er de ældre, som har besvaret og returneret skemaerne.

I hvilket omfang dette har betydning for anvendeligheden af data og pålideligheden de analyseresultater, som er fremkommet på baggrund af de data, som er indsamlet, kan der på den ene side ikke svares generelt på. På den anden side er det indlysende, at resultater, der forsøger at tegne et (generelt) billede af alle pædagoger eller alle omsorgsmedhjælpere, kan blive påvirket af en skæv aldersfordeling, hvis det er sådan at det forhold, man ønsker at beskrive er afhængig af alderen. Det kunne være spørgsmål om ønsker vedrørende at "tage flere initiativer", "deltage i efteruddannelsesaktiviteter" eller lignende, som sikkert er afhængig af, om man er ung eller ældre. En generel udmelding, baseret på observationerne $i$ data, der siger at "x procent er interesseret i efteruddannelse" bliver dermed for $h \varnothing j$, når man fra frafaldsanalysen ved, at det især er de unges svar som man (uforholdsmæssigt tungt) lægger til grund for udmeldingen.

Generelt kan man undgå negative bivirkninger af de markeringer af 'skæve' fordelinger, som er vist i tabellerne $\mathrm{E}$ og $\mathrm{F}$ ved ikke at fortolke rapporterede hyppigheder og gennemsnit alt for detaljeret. Det vil altså være hensigtsmæssigt at lægge vægt på fortolkninger af enkelttal og resultater af sammenligninger, som ikke medtager 'sidste decimal' i vurderingerne. 


\section{Bilag 2. Om det antropologiske feltstudie}

Det antropologiske feltstudie til projektet fandt sted i et bo- og dagtilbud i København og foregik fra den 10. til den 23. oktober 2007. Således varede feltarbejdet to uger.

Under feltarbejdet fordelte jeg min tid tilnærmelsesvis ligeligt mellem dagtilbuddet og de to botilbud, hvortil jeg havde adgang. Jeg var der på alle tider af dagen og ugen: morgen, middag, aften, hverdage og i weekenderne - mellem to og ti timer af gangen. Nogle dage et af stederne i 'et stræk', andre dage delte jeg dagen og var i botilbud om morgenen og fulgte så beboerne til dagtilbuddet, eller jeg var i dagtilbud og derefter på aftenfeltstudier i botilbud.

Alle beboere og medarbejdere er anonymiseret af hensyn til både tavshedspligt, deres ret til privatliv og arbejdsro. Ligeledes er selve feltarbejdsstederne anonymiseret.

I feltstudier får man sin viden gennem roller i felten. Man kan se rollerne i felten som relationer mellem feltens mennesker og feltarbejderen. For rollerne opstår og bliver tilgængelige gennem aflæsning og afprøvning af muligheder i de konkrete sociale sammenhænge - det vil sige alle de forskelligartede hverdagssituationer, man er sammen i i hverdagen. Det er både roller der opstår, fordi man direkte og med små tegn inviteres til at indgå, og det er sammenhænge/situationer, man selv ihærdigt forsøger at finde mulighed for at indgå i, så man kan blive del af den levede virkelighed på en hensigtsmæssig og feltlegitim måde, der leves i felten.

Antropologisk viden indebærer en uendelig vekselvirkning, i alle processer af et antropologisk projekt, mellem bestræbelser på indlevende nærhed og analytisk afstand.

Inde i felten er det ved direkte deltagelse og tilstræbt tilbagetrukket observation, sammen med det fortolkende og analytiske arbejder der foregår i notat-processen både i feltnoterne, som jeg skrev undervejs og i dagbogsoptegnelserne efter hver feltarbejdsdag.

I den proces det er at arbejde med et antropologisk perspektiv, kan man sige, at der foregår en ligeværdig vekselvirkning mellem hypoteser om, hvad alt det man bliver del af $\mathrm{i}$ felten kan betyde, systematisk arbejde med unders $\varnothing$ gelsesmetoderne og data skabt gennem timers samvær ude i bo- og dagtilbud.

Den vekselvirkning fortsætter hjemme ved skrivebordet. Men nu er det mest afstanden, der er fremherskende. Her undersøges mønstre, sammenhænge og forskelligheder i samspillet i det daglige liv og den daglige pædagogiske praksis som beboere, brugere og medarbejdere åbnede ude i felten. Det formidles i en feltberetning, som udtryk for et perspektiv eller en historie om socialpædagogik og hverdagssamspil i botilbud. Formidlingen sker gennem kategorier genereret af det analytiske arbejde - i min feltberetning med fortolkninger af kontaktsomhed. 


\section{Bilag 3. Spørgeskemaundersøgelsens data}

Københavnerundersøgelsen

Spørgeskema til pædagoger og omsorgsmedhjælpere i bo- og dagtilbud til voksne med varig nedsat fysisk eller psykisk funktionsevne

35 spørgsmål med underspørgsmål inkl. svarfordelinger i procent opgjort på alle medarbejdere og særskilt på pædagoger og omsorgsmedhjælpere.

Antal besvarede spørgeskemaer: $245(n=245)$

\section{Ansættelse og arbejdspladsen}

Tabel 1A. Medarbejdergrupper

\begin{tabular}{|l|l|}
\hline Stillingskategori & Antal \\
\hline Pædagog & 176 \\
\hline Omsorgsmedhjælper & 66 \\
\hline I alt & 242 \\
\hline
\end{tabular}

Tabel 1A1. Deltagende medarbejdere og bo/dagtilbud

\begin{tabular}{|l|l|l|}
\hline Bo- og dagtilbud & Antal & $\begin{array}{l}\text { Deltagende medar- } \\
\text { bejdere }\end{array}$ \\
\hline Bo- og dagtilbud & 22 & $\begin{array}{l}\text { Spredning: 0-23 } \\
\text { Gennemsnit: 7 } \\
\text { Typetal: 6 }\end{array}$ \\
\hline $\begin{array}{l}\text { Deltagende pædagoger i de 22 } \\
\text { bo/dagtilbud }\end{array}$ & 170 & $\begin{array}{l}\text { Spredning: 0-16 } \\
\text { Gennemsnit: 2ํㅡㄹ } \\
\text { Typetal: 1 }\end{array}$ \\
\hline $\begin{array}{l}\text { Deltagende omsorgsmedhjæl- } \\
\text { pere i de 22 bo/dagtilbud }\end{array}$ & 56 & $\begin{array}{l}\text { Spredning: 1-39 } \\
\text { Gennemsnit: 10 } \\
\text { Typetal: 7 }\end{array}$ \\
\hline $\begin{array}{l}\text { Deltagende pædagoger og om- } \\
\text { sorgsmedhjælpere i de 22 } \\
\text { bo/dagtilbud }\end{array}$ & 226 & \\
\hline
\end{tabular}

Tabel 1B. Ansættelsesform

\begin{tabular}{|l|l|l|l|}
\hline Ansættelsesform & Alle i \% & $\begin{array}{l}\text { Antal pædagoger } \\
\mathbf{i} \%\end{array}$ & $\begin{array}{l}\text { Antal omsorgs- } \\
\text { medhjælpere } \\
\text { i } \% \\
\mathrm{~N}=64\end{array}$ \\
\hline Fastansat & 89 & $\mathrm{~N}=174$ & 69 \\
\hline Vikar: Fast tilkaldevikar & 6 & 96 & 23 \\
\hline $\begin{array}{l}\text { Vikar: Længerevarende } \\
\text { vikariat (f.eks. barsels- } \\
\text { vikariat) }\end{array}$ & 5 & 0 & 8 \\
\hline
\end{tabular}


Tabel 1C. Arbejdsfunktion

\begin{tabular}{|l|l|l|l|}
\hline Arbejdsfunktion & $\begin{array}{l}\text { Alle } \\
\mathbf{i} \% \\
\mathrm{~N}=241\end{array}$ & $\begin{array}{l}\text { Antal pædagoger } \\
\mathbf{i} \% \\
\mathrm{~N}=174\end{array}$ & $\begin{array}{l}\text { Antal omsorgs } \\
\text { medhæjpere } \\
\mathbf{i} \% \\
\mathrm{~N}=65\end{array}$ \\
\hline Arbejder kun i botilbud & 93 & 94 & 89 \\
\hline Arbejder kun i dagtilbud & 2 & 2 & 0 \\
\hline $\begin{array}{l}\text { Arbejder både i botilbud } \\
\text { og dagtilbud }\end{array}$ & 6 & 4 & 11 \\
\hline
\end{tabular}

\section{Karakteristik af beboerne/ brugerne}

Tabel 2. Hvilke beboere og brugere der arbejdes med

\begin{tabular}{|l|l|l|l|}
\hline Brugerkarakteristik & $\begin{array}{l}\text { Alle i \% } \\
\mathrm{N}=463\end{array}$ & $\begin{array}{l}\text { Pædagoger } \\
\text { i \% af alle } \\
\text { pædagoger }\end{array}$ & $\begin{array}{l}\text { Omsorgs- } \\
\text { medhæælpere } \\
\text { i \% af alle om- } \\
\text { sorgsmedhjæl- } \\
\text { pere }\end{array}$ \\
\hline $\begin{array}{l}\text { Voksne med udviklings- } \\
\text { hæmning }\end{array}$ & 90 & 91 & 85 \\
\hline $\begin{array}{l}\text { Voksne fysisk handicap- } \\
\text { pede }\end{array}$ & 30 & 28 & 36 \\
\hline $\begin{array}{l}\text { Voksne psykisk handi- } \\
\text { cappede (f.eks. auti- } \\
\text { ster) }\end{array}$ & 52 & 47 & 65 \\
\hline $\begin{array}{l}\text { Voksne senhjerneska- } \\
\text { dede }\end{array}$ & 10 & 8 & 15 \\
\hline Andre & 9 & 11 & 2 \\
\hline
\end{tabular}

Hvilke beboere/ brugere arbejder du med på den boenhed/ afdeling/ dagtilbud, du er tilknyttet?

Tabel 2.1. Voksne med udviklingshæmning

\begin{tabular}{|l|l|l|}
\hline $\begin{array}{l}\text { Antal voksne med udvik- } \\
\text { lingshæmning }\end{array}$ & $\begin{array}{l}\text { Antal pædagoger } \\
\mathbf{i} \% \\
\mathrm{~N}=122\end{array}$ & $\begin{array}{l}\text { Antal omsorgsmedhjæl- } \\
\text { pere i \% } \\
\mathrm{N}=35\end{array}$ \\
\hline $1-5$ & 15 & 29 \\
\hline $6-10$ & 43 & 31 \\
\hline $11-15$ & 31 & 14 \\
\hline $16-20$ & 7 & 14 \\
\hline $21-25$ & 2 & 3 \\
\hline $26-$ & 2 & 9 \\
\hline
\end{tabular}

Tabel 2.2. Voksne fysisk handicappede

\begin{tabular}{|l|l|l|}
\hline $\begin{array}{l}\text { Antal voksne fysisk han- } \\
\text { dicappede }\end{array}$ & $\begin{array}{l}\text { Antal pædagoger } \\
\mathbf{i} \% \\
\mathrm{~N}=14\end{array}$ & $\begin{array}{l}\text { Antal omsorgsmedhjæl- } \\
\text { pere i \% } \\
\mathrm{N}=10\end{array}$ \\
\hline $1-5$ & 36 & 20 \\
\hline $6-10$ & 64 & 60 \\
\hline $11-15$ & 0 & 10 \\
\hline $16-20$ & 0 & 10 \\
\hline
\end{tabular}


Tabel 2.3. Voksne psykisk handicappede (f.eks. autister)

\begin{tabular}{|l|l|l|}
\hline $\begin{array}{l}\text { Antal voksne psykisk } \\
\text { handicappede }\end{array}$ & $\begin{array}{l}\text { Antal pædagoger } \\
\mathbf{i} \% \\
\mathrm{~N}=47\end{array}$ & $\begin{array}{l}\text { Antal omsorgsmedhjæl- } \\
\text { pere i \% } \\
\mathrm{N}=24\end{array}$ \\
\hline $1-5$ & 47 & 46 \\
\hline $6-10$ & 38 & 37 \\
\hline $11-15$ & 11 & 4 \\
\hline $16-20$ & 4 & 13 \\
\hline
\end{tabular}

Tabel 2.4. Voksne senhjerneskadede

\begin{tabular}{|l|l|l|}
\hline Antal senhjerneskadede & $\begin{array}{l}\text { Antal pædagoger } \\
\mathbf{i} \% \\
\mathrm{~N}=6\end{array}$ & $\begin{array}{l}\text { Antal omsorgsmedhjæl- } \\
\text { pere i \% } \\
\mathrm{N}=4\end{array}$ \\
\hline $1-5$ & 83 & 50 \\
\hline $6-10$ & 17 & 50 \\
\hline
\end{tabular}

Tabel 2.5. Andre, da hvilke? (Flest nævner voksne udviklingshæmmede med psykiatrisk overbygning. Også det mere ubestemmelige Komplekse problemstillinger / enkeltmandsprojekter synes at dække flere problemstillinger. Endvidere nævnes demente og scleroseramte).

\begin{tabular}{|l|l|l|}
\hline Antal andre & $\begin{array}{l}\text { Antal pædagoger } \\
\mathbf{i} \% \\
\mathrm{~N}=10\end{array}$ & $\begin{array}{l}\text { Antal omsorgsmed- } \\
\text { hjælpere i \% } \\
\mathrm{N}=2\end{array}$ \\
\hline $1-5$ & 60 & 0 \\
\hline $6-10$ & 30 & 100 \\
\hline $11-15$ & 10 & 0 \\
\hline
\end{tabular}

Tabel 2A. Domsanbragte beboere/brugere

\begin{tabular}{|c|c|c|c|}
\hline $\begin{array}{l}\text { Er der domsanbragte beboe- } \\
\text { re/ brugere pà boen- } \\
\text { hed/ afdeling/ dagtilbud, du } \\
\text { er tilknyttet? }\end{array}$ & $\begin{array}{l}\text { Alle i \% } \\
N=234\end{array}$ & $\begin{array}{l}\text { Antal } \\
\text { pædagoger } \\
\text { i \% } \\
\mathrm{N}=169\end{array}$ & $\begin{array}{l}\text { Antal } \\
\text { omsorgs- } \\
\text { medhjælpere } \\
\text { i \% } \\
\mathrm{N}=63\end{array}$ \\
\hline Ja & 11 & 9 & 14 \\
\hline Nej & 86 & 89 & 78 \\
\hline Ved ikke & 3 & 2 & 8 \\
\hline
\end{tabular}


Tabel 3A. Vurdering af den overvejende del af beboere/brugere i forhold til verbal kommunikation

På en skala fra 1-10, hvor 1 er ringe og 10 er god, hvor vil du placere den overvejende del af dine beboere/brugere i forhold til verbal kommunikation:

\begin{tabular}{|l|l|l|l|l|l|l|l|l|l|l|}
\hline $\begin{array}{l}\text { Verbal } \\
\text { kommuni- } \\
\text { kation }\end{array}$ & $\begin{array}{l}\mathbf{1} \\
\text { Ringe } \\
\%\end{array}$ & $\mathbf{2}$ & $\mathbf{3}$ & $\mathbf{4}$ & $\mathbf{5}$ & $\mathbf{6}$ & $\mathbf{7}$ & $\mathbf{8}$ & $\mathbf{9}$ & $\begin{array}{l}\mathbf{1 0} \\
\text { God } \\
\%\end{array}$ \\
\hline Alle & 11 & 12 & 14 & 10 & 12 & 6 & 14 & 11 & 6 & 5 \\
\hline Pædagoger & 11 & 12 & 13 & 8 & 14 & 5 & 13 & 12 & 7 & 5 \\
\hline $\begin{array}{l}\text { Omsorgs- } \\
\text { medhjælpe- } \\
\text { re }\end{array}$ & 11 & 11 & 17 & 15 & 5 & 11 & 17 & 7 & 2 & 4 \\
\hline
\end{tabular}

Tabel 3B. Vurdering af den overvejende del af dine beboere/brugere i forhold til fysisk mobilitet

På en skala fra 1-10, hvor 1 er lav og 10 er høj grad, hvor vil du placere den overvejende del af dine beboere/brugere i forhold til fysisk mobilitet:

\begin{tabular}{|l|l|l|l|l|l|l|l|l|l|l|}
\hline $\begin{array}{l}\text { Fysisk } \\
\text { mobilitet }\end{array}$ & $\begin{array}{l}\mathbf{1} \\
\text { Lav } \\
\%\end{array}$ & $\begin{array}{l}\mathbf{2} \\
\text { \% }\end{array}$ & $\begin{array}{l}\mathbf{3} \\
\%\end{array}$ & $\begin{array}{l}\mathbf{4} \\
\text { \% }\end{array}$ & $\begin{array}{l}\mathbf{5} \\
\%\end{array}$ & $\begin{array}{l}\mathbf{6} \\
\text { \% }\end{array}$ & $\begin{array}{l}\mathbf{7} \\
\%\end{array}$ & $\begin{array}{l}\mathbf{8} \\
\%\end{array}$ & $\begin{array}{l}\mathbf{9} \\
\%\end{array}$ & $\begin{array}{l}\mathbf{1 0} \\
\text { Høj } \\
\%\end{array}$ \\
\hline Alle & 1 & 5 & 9 & 11 & 11 & 10 & 9 & 18 & 17 & 8 \\
\hline Pædagoger & 1 & 5 & 7 & 11 & 11 & 10 & 8 & 18 & 19 & 10 \\
\hline $\begin{array}{l}\text { Omsorgs- } \\
\text { medhjælpe- } \\
\text { re }\end{array}$ & 2 & 5 & 14 & 13 & 12 & 9 & 11 & 18 & 12 & 4 \\
\hline
\end{tabular}

Tabel 3C. Vurdering af den overvejende del af dine beboere/brugere i forhold til selvhjulpenhed

På en skala fra 1-10, hvor 1 er lidt og 10 er meget, hvor vil du placere den overvejende del af dine beboere/brugere $\mathrm{i}$ forhold til selvhjulpenhed (kunne klare gøremål selv, gå alene i byen, osv.):

\begin{tabular}{|l|l|l|l|l|l|l|l|l|l|l|}
\hline $\begin{array}{l}\text { Selvhjul- } \\
\text { penhed }\end{array}$ & $\begin{array}{l}\mathbf{1} \\
\text { Lidt } \\
\%\end{array}$ & $\mathbf{2}$ & $\mathbf{3}$ & $\mathbf{4}$ & $\mathbf{5}$ & $\mathbf{6}$ & $\mathbf{7}$ & $\mathbf{8}$ & $\mathbf{9}$ & $\begin{array}{l}\mathbf{1 0} \\
\text { Meget } \\
\%\end{array}$ \\
\hline Alle & 20 & 14 & 14 & 8 & 12 & 10 & 10 & 7 & 4 & 1 \\
\hline $\begin{array}{l}\text { Pædago- } \\
\text { ger }\end{array}$ & 18 & 15 & 14 & 8 & 12 & 9 & 12 & 7 & 4 & 1 \\
\hline $\begin{array}{l}\text { Omsorgs- } \\
\text { medhjæl- } \\
\text { pere }\end{array}$ & 27 & 14 & 14 & 7 & 11 & 11 & 6 & 5 & 5 & 0 \\
\hline
\end{tabular}

Under muligheden for skriftligt at kommentere, om der er eventuelt andre karakteristika ved beboerne/brugerne, som bør fremhæves (udover hvad der er spurgt til), nævnes især problematisk adfærd, flere ældre, og demente. Endvidere nævnes dårligt gående, synsproblemer, grænseoverskridende social adfærd, hygiejne, spisning, enkeltmandsprojekter i små og dårlige forhold 


\section{Personlige data}

Tabel 4. Køn

\begin{tabular}{|l|l|l|}
\hline Køn & $\begin{array}{l}\text { Kvinder } \\
\mathbf{i} \%\end{array}$ & $\begin{array}{l}\text { Mænd } \\
\mathbf{i} \%\end{array}$ \\
\hline Alle & 72 & 28 \\
\hline Pædagoger & 76 & 24 \\
\hline Omsorgsmedhjælpere & 61 & 39 \\
\hline
\end{tabular}

Tabel 5. Alder

\begin{tabular}{|l|l|l|l|l|l|l|l|l|l|}
\hline Alder & $\mathbf{2 0 -}$ & $\mathbf{2 6 -}$ & $\mathbf{3 1 -}$ & $\mathbf{3 6 -}$ & $\mathbf{4 1 -}$ & $\mathbf{4 6 -}$ & $\mathbf{5 1 -}$ & $\mathbf{5 6 -}$ & $\mathbf{6 1 -}$ \\
& $\mathbf{2 5}$ & $\mathbf{3 0}$ & $\mathbf{3 5}$ & $\mathbf{4 0}$ & $\mathbf{4 5}$ & $\mathbf{5 0}$ & $\mathbf{5 5}$ & $\mathbf{6 0}$ & $\mathbf{6 5}$ \\
$\mathbf{i} \%$ & $\mathbf{i} \%$ & $\mathbf{i} \%$ & $\mathbf{i} \%$ & $\mathbf{i} \%$ & $\mathbf{i} \%$ \\
\hline ille & 10 & 17 & 10 & 10 & 14 & 13 & 9 & 13 & 4 \\
\hline Pædagoger & 5 & 16 & 8 & 9 & 14 & 12 & 12 & 18 & 6 \\
\hline $\begin{array}{l}\text { Omsorgs- } \\
\text { medhjælpere }\end{array}$ & 23 & 17 & 15 & 11 & 14 & 16 & 2 & 2 & 0 \\
\hline
\end{tabular}

Tabel 6. Civilstand

\begin{tabular}{|c|c|c|c|}
\hline Civilstand & $\begin{array}{l}\text { Alle } \\
\text { i \% }\end{array}$ & $\begin{array}{l}\text { Pædagoger } \\
\text { i \% }\end{array}$ & $\begin{array}{l}\text { Omsorgs- } \\
\text { medhjælpere } \\
\text { i \% }\end{array}$ \\
\hline Gift eller samboende & 52 & 56 & 45 \\
\hline Bor sammen med forælder & 0 & 0 & 0 \\
\hline $\begin{array}{l}\text { Bor alene, men har fast kæ- } \\
\text { reste }\end{array}$ & 13 & 12 & 13 \\
\hline Enlig (evt. bofællesskab) & 35 & 32 & 42 \\
\hline
\end{tabular}

Tabel 7. Etnisk baggrund

\begin{tabular}{|l|l|l|l|}
\hline $\begin{array}{l}\text { Har du anden etnisk bag- } \\
\text { grund end dansk? }\end{array}$ & Alle & $\begin{array}{l}\text { Pædagoger } \\
\mathbf{i} \%\end{array}$ & $\begin{array}{l}\text { Omsorgs- } \\
\text { medhjælpere } \\
\mathbf{i} \% \\
\mathrm{~N}=65\end{array}$ \\
\hline $\mathrm{Ja}$ & $\mathrm{N}=236$ & $\mathrm{~N}=169$ & 22 \\
\hline $\mathrm{Nej}$ & 13 & 10 & 75 \\
\hline Ønsker ikke at svare & 85 & 89 & 3 \\
\hline
\end{tabular}

Tabel 8. Medlemskab af fagforening

\begin{tabular}{|l|l|l|l|}
\hline $\begin{array}{l}\text { Er du medlem af en fag- } \\
\text { forening? }\end{array}$ & $\begin{array}{l}\text { Pædagoger } \\
\mathbf{i} \%\end{array}$ & $\begin{array}{l}\text { Omsorgs- } \\
\text { medhjælpere } \\
\mathbf{i} \% 174\end{array}$ & $\begin{array}{l}\text { Alle } \\
\mathrm{N}=63\end{array}$ \\
\hline $\mathrm{Ja}$ & 95 & 63 & $\mathrm{~N}=237$ \\
\hline $\mathrm{Nej}$ & 4 & 32 & 87 \\
\hline$Ø$ Ønsker ikke at svare & 1 & 5 & 11 \\
\hline
\end{tabular}




\section{Den overordnede vurdering af indsatsen i forhold til bebo- erne/ brugerne}

Tabel 9. Prioritering af delmål med indsatsen i bo- og dagtilbud

(Lovbemærkningerne til serviceloven peger på forskellige delmål med indsatsen. Hvilke 2 af nedenstående 5 delmål i den daglige indsats mener du bør være højest prioriterede på det bosted/afdeling/dagtilbud, hvor du arbejder?)

\begin{tabular}{|l|l|l|l|}
\hline $\begin{array}{l}\text { Prioritering af delmål med } \\
\text { indsatsen i bo- og dagtilbud }\end{array}$ & $\begin{array}{l}\text { Pædagoger } \\
\mathrm{N}=174\end{array}$ & $\begin{array}{l}\text { Omsorgs- } \\
\text { Medhjælpere } \\
\mathrm{N}=63\end{array}$ & $\begin{array}{l}\text { Alle } \\
\mathrm{N}=237 \\
\text { (\% af svar i paran- } \\
\text { tes) }\end{array}$ \\
\hline Udvikling af en positiv identitet & 1 & 1 & $\begin{array}{l}1 \\
(28 \%)\end{array}$ \\
\hline $\begin{array}{l}\text { Opøvelse af færdigheder, som } \\
\text { kan kompensere for den ned- } \\
\text { satte funktionsevne }\end{array}$ & 4 & 3 & 4 \\
\hline $\begin{array}{l}\text { Mestring af aktiv livsudfoldelse } \\
\text { i samspil med andre }\end{array}$ & 2 & 4 & $(18 \%)$ \\
\hline $\begin{array}{l}\text { Ydelse af den nødvendige om- } \\
\text { sorg }\end{array}$ & 3 & 2 & 3 \\
\hline $\begin{array}{l}\text { Skabelse af forståelse og rum- } \\
\text { melighed i det omgivende sam- } \\
\text { fund }\end{array}$ & 5 & 5 & 2 \\
\hline
\end{tabular}


Tabel 10. Bostedets muligheder for at skabe gode rammer om beboernes dagligliv (I rapporten 'Veje til et godt liv i egen bolig' opridses en række pejlemærker for beboernes "mulighed for et godt liv på egne præmisser i botilbud." Hvor vil du indplacere det botilbud/den afdeling, du er tilknyttet, i forhold til graden af målopfyldelse på følgende spørgsmål?)

\begin{tabular}{|l|l|l|l|l|l|l|}
\hline $\begin{array}{l}\text { Bostedets muligheder for at } \\
\text { skabe gode rammer om be- } \\
\text { boernes dagligliv }\end{array}$ & $\begin{array}{l}\text { Meget } \\
\text { høj }\end{array}$ & Høj & $\begin{array}{l}\text { Mid- } \\
\text { del }\end{array}$ & Lav & $\begin{array}{l}\text { Meget } \\
\text { lav }\end{array}$ & $\begin{array}{l}\text { Ved } \\
\text { ikke }\end{array}$ \\
& $\begin{array}{l}\text { Antal i } \\
\%\end{array}$ & $\begin{array}{l}\text { Antal i } \\
\%\end{array}$ & $\begin{array}{l}\text { Antal i } \\
\%\end{array}$ & $\begin{array}{l}\text { Antal i } \\
\%\end{array}$ & $\begin{array}{l}\text { Antal i } \\
\%\end{array}$ & $\begin{array}{l}\text { Antal i } \\
\%\end{array}$ \\
\hline
\end{tabular}

Beboernes selvbestemmelse og indflydelse på eget liv

\begin{tabular}{|l|l|l|l|l|l|l|}
\hline Alle N=230 & 17 & 37 & 27 & 11 & 8 & 0 \\
\hline Pædagoger N=165 & 18 & 35 & 27 & 11 & 9 & 0 \\
\hline Omsorgsmedhjælpere N=63 & 14 & 41 & 27 & 13 & 5 & 0 \\
\hline
\end{tabular}

Beboernes oplevelse af at have eget hjem og privatliv ("råderum og roderum")

\begin{tabular}{|l|l|l|l|l|l|l|}
\hline Alle $\mathrm{N}=231$ & 23 & 31 & 25 & 11 & 9 & 2 \\
\hline Pædagoger $\mathrm{N}=165$ & 23 & 32 & 25 & 11 & 7 & 2 \\
\hline Omsorgsmedhjælpere $\mathrm{N}=64$ & 23 & 30 & 23 & 9 & 13 & 2 \\
\hline Beboernes muligheder for at kommunikere på egne betingelser \\
\hline Alle $\mathrm{N}=231$ & 21 & 45 & 23 & 7 & 4 & 0 \\
\hline Pædagoger $\mathrm{N}=165$ & 21 & 46 & 23 & 6 & 4 & 0 \\
\hline Omsorgsmedhjælpere $\mathrm{N}=64$ & 20 & 42 & 24 & 9 & 3 & 2 \\
\hline
\end{tabular}

\section{Beboernes daglige stimuli: Udfordringer $\mathrm{i}$ forhold til individuelle ønsker og} behov

\begin{tabular}{|l|l|l|l|l|l|l|}
\hline Alle $\mathrm{N}=229$ & 10 & 28 & 45 & 12 & 3 & 1 \\
\hline Pædagoger $\mathrm{N}=164$ & 10 & 30 & 43 & 13 & 3 & 1 \\
\hline Omsorgsmedhjælpere $\mathrm{N}=63$ & 8 & 25 & 51 & 11 & 3 & 2 \\
\hline
\end{tabular}

Beboernes indflydelse på, hvor de bor og hvem de bor sammen med Alle $\mathrm{N}=229$

Pædagoger $\mathrm{N}=163$

Omsorgsmedhjælpere $\mathrm{N}=64$

\begin{tabular}{|l|l|l|l|l|l|}
\hline 3 & 7 & 16 & 17 & 50 & 7 \\
\hline 2 & 7 & 17 & 17 & 53 & 4 \\
\hline 5 & 8 & 14 & 17 & 42 & 14 \\
\hline
\end{tabular}

Beboernes oplevelse af tryghed i hjemmet

\begin{tabular}{|l|l|l|l|l|l|l|}
\hline Alle $\mathrm{N}=229$ & 19 & 41 & 27 & 8 & 3 & 3 \\
\hline Pædagoger $\mathrm{N}=163$ & 19 & 37 & 29 & 8 & 4 & 3 \\
\hline Omsorgsmedhjælpere $\mathrm{N}=64$ & 19 & 50 & 23 & 6 & 0 & 2 \\
\hline
\end{tabular}

Bostedets evne til at skabe plads til spontanitet i hverdagen med beboerne/ brugerne

\begin{tabular}{|l|l|l|l|l|l|l|}
\hline Alle $\mathrm{N}=229$ & 6 & 24 & 43 & 17 & 8 & 1 \\
\hline Pædagoger N=163 & 7 & 26 & 42 & 17 & 7 & 1 \\
\hline Omsorgsmedhjælpere N=64 & 3 & 20 & 45 & 19 & 11 & 2 \\
\hline
\end{tabular}

En kultur på arbejdspladsen præget af åbenhed og respekt samt etik og værdier

\begin{tabular}{|l|l|l|l|l|l|l|}
\hline Alle N=230 & 29 & 44 & 18 & 5 & 3 & 0 \\
\hline Pædagoger N=164 & 29 & 46 & 18 & 4 & 2 & 1 \\
\hline Omsorgsmedhjælpere N=64 & 31 & 39 & 16 & 9 & 5 & 0 \\
\hline Faglighed i den pædagogiske indsats som helhed \\
\hline Alle N=230 & 27 & 44 & 20 & 6 & 2 & 1 \\
\hline Pædagoger N=164 & 27 & 44 & 21 & 6 & 2 & 0 \\
\hline Omsorgsmedhjælpere N=64 & 26 & 44 & 16 & 8 & 3 & 3 \\
\hline
\end{tabular}




\section{Det aktuelle arbejde}

Tabel 11. Længde af din nuværende ansættelse

\begin{tabular}{|c|c|c|c|}
\hline $\begin{array}{l}\text { Længde af nuværende ansæt- } \\
\text { telse? }\end{array}$ & $\begin{array}{l}\text { Pædagoger } \\
\text { i \% } \\
\mathrm{N}=160\end{array}$ & $\begin{array}{l}\text { Omsorgs- } \\
\text { medhjælpere } \\
\text { i \% } \\
\mathrm{N}=59\end{array}$ & $\begin{array}{l}\text { Alle } \\
\text { i \% } \\
\mathbf{N}=\mathbf{2 1 9}\end{array}$ \\
\hline Under 6 måneder & 10 & 8 & 10 \\
\hline Fra 6 måneder til under 1 år & 12 & 15 & 13 \\
\hline Fra 1 àr til under 2 år & 14 & 27 & 17 \\
\hline Fra 2 år til under 3 år & 6 & 12 & 8 \\
\hline Fra 3 år til under 5 år & 11 & 17 & 12 \\
\hline Fra 5 àr til under 10 år & 24 & 14 & 21 \\
\hline Fra 10 år til under år 20 år & 23 & 7 & 19 \\
\hline Fra 20 år og opefter & 0 & 0 & 0 \\
\hline
\end{tabular}

Tabel 12. Ugentlig arbejdstid

\begin{tabular}{|c|c|c|c|}
\hline Ugentlig arbejdstid & $\begin{array}{l}\text { Pædagoger } \\
\text { i \% } \\
\mathrm{N}=173\end{array}$ & $\begin{array}{l}\text { Omsorgs- } \\
\text { medhjælpere } \\
\text { i \% } \\
\mathrm{N}=61\end{array}$ & $\begin{array}{l}\text { Alle } \\
\text { i \% } \\
N=234\end{array}$ \\
\hline Op til 19 timer & 1 & 15 & 4 \\
\hline Mellem 20 og 27 timer & 3 & 5 & 4 \\
\hline Mellem 28 og 31 timer & 5 & 7 & 6 \\
\hline Mellem 32 og 36 timer & 11 & 20 & 13 \\
\hline 37 timer eller mere ( fuld tid) & 80 & 54 & 73 \\
\hline
\end{tabular}

Tabel 13. Tilfredshed med nuværende timetal

\begin{tabular}{|c|c|c|c|}
\hline $\begin{array}{l}\text { Tilfredshed med nuværende } \\
\text { timetal }\end{array}$ & $\begin{array}{l}\text { Pædagoger } \\
\text { i \% } \\
N=174\end{array}$ & $\begin{array}{l}\text { Omsorgs- } \\
\text { medhjælpere } \\
\text { i \% } \\
\mathrm{N}=64\end{array}$ & $\begin{array}{l}\text { Alle } \\
\mathbf{i} \% \\
\mathbf{N}=\mathbf{2 3 8}\end{array}$ \\
\hline $\mathrm{Ja}$ & 85 & 89 & 86 \\
\hline $\mathrm{Nej}$ & 9 & 5 & 8 \\
\hline Ved ikke & 6 & 6 & 6 \\
\hline
\end{tabular}

Tabel 13A. Om man ved 'nej' til tilfredshed med nuværende timetal ønsker at arbejde flere eller færre timer

\begin{tabular}{|c|c|c|c|}
\hline $\begin{array}{l}\text { Hvis 'nej' til tilfredshed med } \\
\text { nuværende timetal: } \\
\text { Ønsker du at arbejde flere } \\
\text { eller færre timer? }\end{array}$ & $\begin{array}{l}\text { Pædagoger } \\
\text { i \% } \\
\mathrm{N}=24\end{array}$ & $\begin{array}{l}\text { Omsorgs- } \\
\text { medhjælpere } \\
\text { i \% } \\
\mathrm{N}=4\end{array}$ & $\begin{array}{l}\text { Alle } \\
\mathbf{i} \% \\
\mathbf{N}=\mathbf{2 8}\end{array}$ \\
\hline Ønsker at arbejde i flere timer & 0 & 50 & 7 \\
\hline Ønsker at arbejde i færre timer & 100 & 50 & 93 \\
\hline
\end{tabular}


Tabel 14. Varierende arbejdstid

\begin{tabular}{|l|l|l|l|}
\hline Varierende arbejdstid & Pædagoger & $\begin{array}{l}\text { Omsorgs- } \\
\text { medhæælpere }\end{array}$ & $\begin{array}{l}\text { Alle } \\
\mathbf{i} \%\end{array}$ \\
& $\mathbf{i} \%$ & $\mathbf{i} \%$ & $\mathrm{~N}=65$ \\
$\mathrm{~N}=174$ & 85 & 92 \\
\hline $\mathrm{Ja}$ & 95 & 15 & 8 \\
\hline $\mathrm{Nej}$ & 5 & & 239 \\
\hline
\end{tabular}

* Hvis 'nej' til varierende arbejdstider:

Tabel 14A.1. Fast aftenvagt

\begin{tabular}{|c|c|c|c|}
\hline Fast aftenvagt & $\begin{array}{l}\text { Pædagoger } \\
\text { i \% } \\
\mathrm{N}=54\end{array}$ & $\begin{array}{l}\text { Omsorgs- } \\
\text { medhjælpere } \\
\text { i \% } \\
\mathrm{N}=20\end{array}$ & $\begin{array}{l}\text { Alle } \\
\text { i } \% \\
\mathbf{N}=\mathbf{7 4}\end{array}$ \\
\hline Arbejder fast som aftenvagt & $11(6)$ & $10(2)$ & 11 \\
\hline Arbejder ikke fast som aftenvagt & 89 & 90 & 89 \\
\hline
\end{tabular}

Tabel 14A.2. Fast nattevagt

\begin{tabular}{|l|l|l|l|}
\hline Fast nattevagt & Pædagoger & $\begin{array}{l}\text { Omsorgs- } \\
\text { medhjælpere } \\
\mathbf{i} \%\end{array}$ & $\begin{array}{l}\text { Alle } \\
\mathbf{i}=27\end{array}$ \\
& $\begin{array}{l}\mathbf{i} \% \\
\mathrm{~N}=49\end{array}$ & $\mathbf{N = 7 6}$ \\
\hline Arbejder fast som nattevagt & $4(2)$ & $37(10)$ & 16 \\
\hline Arbejder ikke fast som nattevagt & 96 & 63 & 84 \\
\hline
\end{tabular}

* Hvis 'ja' til varierende arbejdstider, hvordan varierer arbejdstiden:

Tabel 14B. Hvordan arbejdstiden varierer

\begin{tabular}{|l|l|l|l|}
\hline $\begin{array}{l}\text { Hvordan arbejdstiden varie- } \\
\text { rer }\end{array}$ & $\begin{array}{l}\text { Pædagoger } \\
\mathbf{i} \%\end{array}$ & $\begin{array}{l}\text { Omsorgs- } \\
\text { medhjælpere } \\
\mathbf{i} \%\end{array}$ & $\begin{array}{l}\text { Alle } \\
\text { i \% }\end{array}$ \\
\hline & $\mathbf{N = 1 5 6}$ & $\mathbf{N = 5 5}$ & $\mathbf{N = 2 1 1}$ \\
\hline Arbejdstid varierer i løbet af uge & 96 & 87 & 94 \\
\hline $\begin{array}{l}\text { Arbejdstid varierer ikke i løbet af } \\
\text { uge }\end{array}$ & 4 & 13 & 6 \\
\hline & $\mathbf{N = 1 2 1}$ & $\mathbf{N}=\mathbf{4 4}$ & $\mathbf{N = 1 6 5}$ \\
\hline Arbejdstid varierer fra uge til uge & 91 & 84 & 89 \\
\hline $\begin{array}{l}\text { Arbejdstid varierer ikke fra uge } \\
\text { til uge }\end{array}$ & 9 & 16 & 11 \\
\hline $\begin{array}{l}\text { Arbejdstid varierer fra måned til } \\
\text { måned }\end{array}$ & $\mathbf{N = 1 0 2}$ & $\mathbf{N = 3 6}$ & $\mathbf{N = 1 3 8}$ \\
\hline $\begin{array}{l}\text { Arbejdstid varierer ikke fra må- } \\
\text { ned til måned }\end{array}$ & 42 & 50 & 56 \\
\hline
\end{tabular}

* Hvis 'ja' til varierende arbejdstider, forekommer flere arbejdsintervaller om dagen? 
Tabel 14C. Flere arbejdsintervaller

\begin{tabular}{|l|l|l|l|}
\hline $\begin{array}{l}\text { Flere arbejdsintervaller } \\
\text { Forekommer det at du har mere } \\
\text { end et arbejdsinterval om dagen } \\
\text { (dvs. møder på arbejde mere } \\
\text { end én gang på samme arbejds- } \\
\text { dag) }\end{array}$ & $\begin{array}{l}\mathbf{i} \% \\
\mathrm{~N}=169\end{array}$ & $\begin{array}{l}\text { Omsorgs- } \\
\text { medhjælpere } \\
\mathbf{i} \%\end{array}$ & $\begin{array}{l}\text { N }=61 \\
\mathbf{i} \% \\
\mathbf{N}=\mathbf{2 3 0}\end{array}$ \\
\hline $\mathrm{Ja}$ & 11 & 18 & 13 \\
\hline Nej & 89 & 82 & 87 \\
\hline
\end{tabular}

* Hvis 'ja' til varierende arbejdstider, forekommer aften- eller natarbejde? Tabel 14D. Om aften eller natarbejde forekommer

\begin{tabular}{|l|l|l|l|}
\hline $\begin{array}{l}\text { Om aften eller natarbejde fo- } \\
\text { rekommer }\end{array}$ & $\begin{array}{l}\text { Pædagoger } \\
\mathbf{i} \%\end{array}$ & $\begin{array}{l}\text { Omsorgs- } \\
\text { medhjælpere } \\
\mathbf{i} \%\end{array}$ & $\begin{array}{l}\text { Alle } \\
\text { i \% }\end{array}$ \\
\hline Ja til at aftenarbejde forekommer & $\mathbf{N = 1 4 3}$ & $\mathbf{N = 4 4}$ & $\mathbf{N = 1 8 7}$ \\
\hline $\begin{array}{l}\text { Nej til at aftenarbejde forekom- } \\
\text { mer }\end{array}$ & 6 & 93 & 94 \\
\hline & $\mathbf{N = 1 2 5}$ & $\mathbf{N}=\mathbf{4 4}$ & 6 \\
\hline Ja til at natarbejde forekommer & 25 & 45 & $\mathbf{N}=\mathbf{1 8 7}$ \\
\hline Nej til at natarbejde forekommer & 75 & 55 & 30 \\
\hline
\end{tabular}




\section{Arbej dsopgaverne}

Tabel 15. I hvilket omfang har du medansvar for planlægning i forhold til beboere/brugere?

\begin{tabular}{|c|c|c|c|c|c|}
\hline $\begin{array}{l}\text { hvilket omfang har du } \\
\text { medansvar for planlægning i } \\
\text { forhold til beboere/ brugere }\end{array}$ & $\begin{array}{l}\text { I } \\
\text { grad } \\
\text { Antal } \\
\%\end{array}$ & $\begin{array}{l}\text { I nogen } \\
\text { grad } \\
\text { Antal i } \\
\%\end{array}$ & $\begin{array}{l}\text { I ringe } \\
\text { grad } \\
\text { Antal i } \\
\%\end{array}$ & $\begin{array}{l}\text { Slet } \\
\text { ikke } \\
\text { Antal i } \\
\%\end{array}$ & 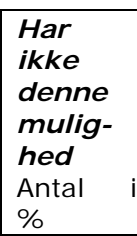 \\
\hline \multicolumn{6}{|l|}{ I forhold til den daglige omsorg } \\
\hline Alle $\mathrm{N}=237$ & 77 & 20 & 0 & 1 & 2 \\
\hline Pædagoger $\mathrm{N}=172$ & 85 & 14 & 0 & 0 & 1 \\
\hline Omsorgsmedhjælpere $\mathrm{N}=64$ & 55 & 34 & 0 & 5 & 6 \\
\hline \multicolumn{6}{|c|}{ I forhold til den daglige beskæftigelse } \\
\hline Alle $\mathrm{N}=234$ & 41 & 42 & 9 & 4 & 3 \\
\hline Pædagoger $\mathrm{N}=169$ & 43 & 42 & 10 & 3 & 2 \\
\hline Omsorgsmedhjælpere $\mathrm{N}=64$ & 36 & 41 & 8 & 9 & 6 \\
\hline \multicolumn{6}{|c|}{ I forhold til beboernes mulighed for kommunikation på egne betingelser } \\
\hline Alle $\mathrm{N}=233$ & 51 & 39 & 7 & 2 & 1 \\
\hline Pædagoger $\mathrm{N}=168$ & 59 & 36 & 4 & 0 & 1 \\
\hline Omsorgsmedhjælpere $\mathrm{N}=64$ & 28 & 47 & 16 & 6 & 3 \\
\hline \multicolumn{6}{|c|}{$\begin{array}{l}\text { I forhold til beboernes mulighed for stimulering/ udfordringer efter egne } \\
\text { ønsker/ behov }\end{array}$} \\
\hline Alle $\mathrm{N}=233$ & 44 & 40 & 12 & 2 & 2 \\
\hline Pædagoger $\mathrm{N}=168$ & 50 & 40 & 8 & 1 & 1 \\
\hline Omsorgsmedhjælpere $\mathrm{N}=64$ & 28 & 41 & 20 & 6 & 5 \\
\hline \multicolumn{6}{|c|}{$\begin{array}{l}\text { I forhold til beboernes mu- } \\
\text { lighed for at træffe egne be- } \\
\text { slutninger }\end{array}$} \\
\hline Alle $\mathrm{N}=232$ & 47 & 38 & 11 & 2 & 3 \\
\hline Pædagoger $\mathrm{N}=168$ & 54 & 34 & 9 & 1 & 2 \\
\hline Omsorgsmedhjælpere $\mathrm{N}=63$ & 30 & 44 & 16 & 5 & 5 \\
\hline
\end{tabular}


Tabel 16. Omfang af deltagelse i aktiviteter og opgaver?

\begin{tabular}{|c|c|c|c|c|c|c|}
\hline $\begin{array}{l}\text { I hvilket omfang deltager } \\
\text { du i følgende aktiviteter } \\
\text { og opgaver? } \\
\text { A. Omsorgsrettede aktivi- } \\
\text { teter }\end{array}$ & $\begin{array}{l}\begin{array}{l}\text { Flere } \\
\text { gange } \\
\text { om } \\
\text { dagen }\end{array} \\
\begin{array}{l}\text { Antal i } \\
\%\end{array}\end{array}$ & $\begin{array}{l}\text { Ca. én } \\
\text { gang } \\
\text { om } \\
\text { dagen }\end{array}$ & $\begin{array}{l}\begin{array}{l}\text { Nogle } \\
\text { gange } \\
\text { om } \\
\text { ugen }\end{array} \\
\text { Antal i } \\
\%\end{array}$ & $\begin{array}{l}\text { Mindre } \\
\text { end én } \\
\text { gang } \\
\text { om } \\
\text { ugen } \\
\text { Antal i } \\
\%\end{array}$ & $\begin{array}{l}\text { Antal i } \\
\%\end{array}$ & $\begin{array}{l}\text { Har } \\
\text { ikke } \\
\text { mulig- } \\
\text { hed } \\
\text { for } \\
\text { denne } \\
\text { aktivi- } \\
\text { tet } \\
\text { Antal i } \\
\% \\
\end{array}$ \\
\hline \multicolumn{7}{|c|}{ Omsorg ifm. bad og personhygiejne } \\
\hline Alle $\mathrm{N}=238$ & 53 & 18 & 17 & 7 & 5 & 1 \\
\hline Pædagoger $\mathrm{N}=174$ & 53 & 18 & 16 & 7 & 6 & 0 \\
\hline Omsorgsmedhjælpere $\mathrm{N}=62$ & 50 & 19 & 21 & 6 & 2 & 2 \\
\hline \multicolumn{7}{|c|}{ Omsorg som toiletbesøg, bleskift ol. } \\
\hline Alle $\mathrm{N}=235$ & 54 & 7 & 9 & 3 & 26 & 2 \\
\hline Pædagoger $\mathrm{N}=170$ & 52 & 7 & 8 & 2 & 30 & 1 \\
\hline Omsorgsmedhjælpere $\mathrm{N}=63$ & 57 & 8 & 11 & 3 & 19 & 2 \\
\hline \multicolumn{7}{|l|}{ Hjælp til af- og påklædning } \\
\hline Alle $\mathrm{N}=240$ & 43 & 15 & 10 & 7 & 23 & 2 \\
\hline Pædagoger $\mathrm{N}=174$ & 44 & 11 & 11 & 8 & 25 & 1 \\
\hline Omsorgsmedhjælpere $\mathrm{N}=64$ & 39 & 24 & 9 & 5 & 20 & 3 \\
\hline \multicolumn{7}{|c|}{ Ordner beboernes tøj og lejlighed } \\
\hline Alle $\mathrm{N}=237$ & 37 & 23 & 26 & 11 & 2 & 1 \\
\hline Pædagoger $\mathrm{N}=173$ & 39 & 22 & 25 & 12 & 2 & 0 \\
\hline Omsorgsmedhjælpere $\mathrm{N}=62$ & 32 & 24 & 28 & 10 & 3 & 3 \\
\hline \multicolumn{7}{|c|}{ Lægge beboere til at sove/ vækker dem } \\
\hline Alle $\mathrm{N}=236$ & 36 & 30 & 18 & 3 & 11 & 1 \\
\hline Pædagoger $\mathrm{N}=171$ & 36 & 27 & 18 & 4 & 14 & 1 \\
\hline Omsorgsmedhjælpere $\mathrm{N}=63$ & 40 & 38 & 17 & 2 & 3 & 0 \\
\hline
\end{tabular}




\begin{tabular}{|c|c|c|c|c|c|c|}
\hline $\begin{array}{l}\text { I hvilket omfang deltager } \\
\text { du i følgende aktiviteter } \\
\text { og opgaver? } \\
\text { B. Fritidsrettede aktivite- } \\
\text { ter }\end{array}$ & $\begin{array}{l}\begin{array}{l}\text { Flere } \\
\text { gange } \\
\text { om } \\
\text { dagen }\end{array} \\
\begin{array}{l}\text { Antal i } \\
\%\end{array}\end{array}$ & $\begin{array}{l}\text { Ca. én } \\
\text { gang } \\
\text { om } \\
\text { dagen }\end{array}$ & $\begin{array}{l}\begin{array}{l}\text { Nogle } \\
\text { gange } \\
\text { om } \\
\text { ugen }\end{array} \\
\begin{array}{l}\text { Antal i } \\
\%\end{array}\end{array}$ & $\begin{array}{l}\text { Mindre } \\
\text { end én } \\
\text { gang } \\
\text { om } \\
\text { ugen } \\
\begin{array}{l}\text { Antal i } \\
\%\end{array}\end{array}$ & $\begin{array}{l}\text { Antal i } \\
\%\end{array}$ & $\begin{array}{l}\text { Har } \\
\text { ikke } \\
\text { mulig- } \\
\text { hed } \\
\text { for } \\
\text { denne } \\
\text { aktivi- } \\
\text { tet } \\
\text { Antal i } \\
\%\end{array}$ \\
\hline \multicolumn{7}{|l|}{ Læser højt for beboerne } \\
\hline Alle $\mathrm{N}=235$ & 6 & 7 & 17 & 40 & 26 & 5 \\
\hline Pædagoger $\mathrm{N}=172$ & 6 & 6 & 19 & 41 & 24 & 4 \\
\hline Omsorgsmedhjælpere $\mathrm{N}=61$ & 3 & 10 & 11 & 38 & 31 & 7 \\
\hline \multicolumn{7}{|c|}{ Ser TV sammen med beboerne } \\
\hline Alle $\mathrm{N}=241$ & 13 & 24 & 36 & 18 & 7 & 2 \\
\hline Pædagoger $\mathrm{N}=175$ & 12 & 25 & 36 & 19 & 7 & 1 \\
\hline Omsorgsmedhjælpere $\mathrm{N}=64$ & 17 & 20 & 36 & 14 & 8 & 5 \\
\hline \multicolumn{7}{|c|}{ Spiller spil med beboerne (kort, memory, o.l.) } \\
\hline Alle $\mathrm{N}=237$ & 1 & 4 & 17 & 43 & 25 & 9 \\
\hline Pædagoger $\mathrm{N}=172$ & 1 & 3 & 16 & 47 & 26 & 7 \\
\hline Omsorgsmedhjælpere $\mathrm{N}=63$ & 3 & 3 & 21 & 33 & 26 & 14 \\
\hline \multicolumn{7}{|c|}{ Rytmik, bevægelse, gymnastik, lege } \\
\hline Alle $\mathrm{N}=240$ & 3 & 5 & 15 & 28 & 39 & 11 \\
\hline Pædagoger $\mathrm{N}=174$ & 1 & 4 & 12 & 29 & 44 & 10 \\
\hline Omsorgsmedhjælpere $\mathrm{N}=64$ & 6 & 5 & 22 & 28 & 25 & 14 \\
\hline \multicolumn{7}{|l|}{ Musik, fællessang } \\
\hline Alle $\mathrm{N}=238$ & 4 & 5 & 17 & 38 & 30 & 5 \\
\hline Pædagoger $\mathrm{N}=173$ & 3 & 5 & 15 & 43 & 31 & 3 \\
\hline Omsorgsmedhjælpere $\mathrm{N}=63$ & 8 & 5 & 25 & 24 & 25 & 13 \\
\hline \multicolumn{7}{|l|}{ Tegning, maling } \\
\hline Alle $\mathrm{N}=238$ & 0 & 1 & 10 & 32 & 48 & 9 \\
\hline Pædagoger $\mathrm{N}=172$ & 0 & 1 & 9 & 31 & 51 & 8 \\
\hline Omsorgsmedhjælpere $\mathrm{N}=64$ & 2 & 3 & 11 & 31 & 41 & 12 \\
\hline \multicolumn{7}{|c|}{ Andre aktiviteter, f.eks. sy, arbejde med perler, træe o.l. } \\
\hline Alle $\mathrm{N}=237$ & 2 & 1 & 7 & 32 & 47 & 11 \\
\hline Pædagoger $\mathrm{N}=172$ & 2 & 1 & 5 & 34 & 48 & 10 \\
\hline Omsorgsmedhjælpere $\mathrm{N}=63$ & 3 & 2 & 10 & 25 & 46 & 14 \\
\hline \multicolumn{7}{|c|}{ Udeaktiviteter, gåture, køreture o.I. } \\
\hline Alle $\mathrm{N}=239$ & 13 & 21 & 44 & 18 & 3 & 2 \\
\hline Pædagoger $\mathrm{N}=173$ & 12 & 21 & 49 & 17 & 1 & 0 \\
\hline Omsorgsmedhjælpere $\mathrm{N}=64$ & 13 & 20 & 31 & 20 & 8 & 8 \\
\hline \multicolumn{7}{|l|}{ Biograf, teater og lign. } \\
\hline Alle $\mathrm{N}=241$ & 0 & 0 & 2 & 63 & 24 & 10 \\
\hline Pædagoger $\mathrm{N}=175$ & 1 & 1 & 2 & 66 & 22 & 8 \\
\hline Omsorgsmedhjælpere $\mathrm{N}=64$ & 0 & 0 & 2 & 53 & 30 & 15 \\
\hline \multicolumn{7}{|l|}{ Rejser med overnatning } \\
\hline Alle $\mathrm{N}=222$ & 0 & 0 & 0 & 67 & 24 & 9 \\
\hline Pædagoger $\mathrm{N}=161$ & 0 & 0 & 1 & 77 & 17 & 5 \\
\hline Omsorgsmedhjælpere $\mathrm{N}=59$ & 0 & 0 & 0 & 41 & 42 & 17 \\
\hline
\end{tabular}




\begin{tabular}{|c|c|c|c|c|c|c|}
\hline $\begin{array}{l}\text { I hvilket omfang deltager } \\
\text { du i følgende aktiviteter } \\
\text { og opgaver? } \\
\text { C. Praktiske aktiviteter }\end{array}$ & $\begin{array}{l}\begin{array}{l}\text { Flere } \\
\text { gange } \\
\text { om } \\
\text { dagen }\end{array} \\
\text { Antal i } \\
\%\end{array}$ & $\begin{array}{l}\text { Ca. én } \\
\text { gang } \\
\text { om } \\
\text { dagen } \\
\text { Antal i } \\
\%\end{array}$ & $\begin{array}{l}\text { Nogle } \\
\text { gange } \\
\text { om } \\
\text { ugen } \\
\\
\text { Antal i } \\
\%\end{array}$ & $\begin{array}{l}\text { Mindre } \\
\text { end én } \\
\text { gang } \\
\text { om } \\
\text { ugen } \\
\begin{array}{l}\text { Antal i } \\
\%\end{array}\end{array}$ & $\begin{array}{l}\text { Antal i } \\
\%\end{array}$ & $\begin{array}{l}\text { Har } \\
\text { ikke } \\
\text { mulig- } \\
\text { hed } \\
\text { for } \\
\text { denne } \\
\text { aktivi- } \\
\text { tet } \\
\text { Antal } \\
\% \\
\end{array}$ \\
\hline \multicolumn{7}{|l|}{ Madlavning } \\
\hline Alle $\mathrm{N}=241$ & 28 & 27 & 29 & 8 & 5 & 3 \\
\hline Pædagoger $\mathrm{N}=175$ & 27 & 29 & 30 & 10 & 3 & 1 \\
\hline Omsorgsmedhjælpere $\mathrm{N}=64$ & 31 & 24 & 22 & 3 & 11 & 9 \\
\hline \multicolumn{7}{|l|}{ Oprydning i fællesarealer } \\
\hline Alle $\mathrm{N}=240$ & 42 & 24 & 20 & 9 & 3 & 2 \\
\hline Pædagoger $\mathrm{N}=174$ & 43 & 26 & 19 & 9 & 2 & 1 \\
\hline Omsorgsmedhjælpere $\mathrm{N}=64$ & 39 & 19 & 23 & 8 & 5 & 6 \\
\hline \multicolumn{7}{|l|}{ Borddækning/ afrydning } \\
\hline Alle $\mathrm{N}=240$ & 43 & 23 & 20 & 10 & 2 & 2 \\
\hline Pædagoger $\mathrm{N}=174$ & 45 & 23 & 20 & 10 & 2 & 0 \\
\hline Omsorgsmedhjælpere $\mathrm{N}=64$ & 37 & 22 & 22 & 8 & 3 & 8 \\
\hline \multicolumn{7}{|l|}{ Opvask } \\
\hline Alle $\mathrm{N}=240$ & 48 & 19 & 21 & 7 & 3 & 2 \\
\hline Pædagoger $\mathrm{N}=174$ & 52 & 18 & 29 & 7 & 4 & 0 \\
\hline Omsorgsmedhjælpere $\mathrm{N}=64$ & 41 & 22 & 25 & 5 & 1 & 6 \\
\hline \multicolumn{7}{|l|}{ Rengøring } \\
\hline Alle $\mathrm{N}=239$ & 21 & 17 & 24 & 24 & 12 & 2 \\
\hline Pædagoger $\mathrm{N}=173$ & 18 & 20 & 21 & 27 & 13 & 1 \\
\hline Omsorgsmedhjælpere $\mathrm{N}=27$ & 27 & 9 & 30 & 17 & 11 & 6 \\
\hline \multicolumn{7}{|l|}{ Køber ind for beboerne } \\
\hline Alle $\mathrm{N}=240$ & 8 & 17 & 40 & 25 & 8 & 2 \\
\hline Pædagoger $\mathrm{N}=175$ & 9 & 16 & 38 & 30 & 7 & 0 \\
\hline Omsorgsmedhjælpere $\mathrm{N}=63$ & 3 & 21 & 41 & 14 & 13 & 8 \\
\hline \multicolumn{7}{|l|}{ Reparationer } \\
\hline Alle $\mathrm{N}=236$ & 4 & 2 & 16 & 49 & 26 & 3 \\
\hline Pædagoger $\mathrm{N}=172$ & 3 & 3 & 15 & 52 & 26 & 1 \\
\hline Omsorgsmedhjælpere $\mathrm{N}=62$ & 5 & 0 & 18 & 42 & 26 & 9 \\
\hline \multicolumn{7}{|l|}{ Administrative opgaver } \\
\hline Alle $\mathrm{N}=239$ & 32 & 18 & 30 & 13 & 6 & 2 \\
\hline Pædagoger $\mathrm{N}=173$ & 38 & 18 & 34 & 9 & 1 & 0 \\
\hline Omsorgsmedhjælpere $\mathrm{N}=64$ & 16 & 17 & 20 & 20 & 19 & 8 \\
\hline \multicolumn{7}{|l|}{ Personalemøder og lign. } \\
\hline Alle $\mathrm{N}=236$ & 3 & 6 & 51 & 33 & 4 & 3 \\
\hline Pædagoger $\mathrm{N}=171$ & 4 & 7 & 59 & 28 & 1 & 1 \\
\hline Omsorgsmedhjælpere $\mathrm{N}=63$ & 0 & 5 & 27 & 48 & 11 & 9 \\
\hline
\end{tabular}


Tabel 17. Grad af oplevelse af at arbejdet er vanskeligt i forhold til følgende områder

\begin{tabular}{|l|l|l|l|l|l|}
\hline $\begin{array}{l}\text { I hvilken grad opleves } \\
\text { arbejdet vanskeligt i for- } \\
\text { hold til følgende om råder }\end{array}$ & $\begin{array}{l}\text { grad } \\
\text { vanske- } \\
\text { ligt } \\
\text { Antal i \% }\end{array}$ & $\begin{array}{l}\text { I nogen } \\
\text { grad } \\
\text { vanske- } \\
\text { ligt } \\
\text { Antal i \% }\end{array}$ & $\begin{array}{l}\text { l mindre } \\
\text { grad } \\
\text { vanske- } \\
\text { ligt } \\
\text { Antal i \% }\end{array}$ & $\begin{array}{l}\text { Slet ikke } \\
\text { vanske- } \\
\text { ligt } \\
\text { Antal i \% }\end{array}$ & $\begin{array}{l}\text { Har ikke } \\
\text { denne } \\
\text { opgave }\end{array}$ \\
Antal i \% \\
\hline Den praktiske omsorg for beboere/ brugere \\
\hline Alle N=240 & 3 & 28 & 29 & 38 & 3 \\
\hline Pædagoger N=174 & 5 & 28 & 30 & 36 & 1 \\
\hline Omsorgsmedhjælpere N=64 & 0 & 26 & 25 & 44 & 5 \\
\hline Omsorg i forhold til dine forventninger til passende stimulering/ udfordring \\
\hline Alle N=238 & 10 & 34 & 33 & 21 & 2 \\
\hline Pædagoger N=173 & 11 & 37 & 32 & 19 & 1 \\
\hline Omsorgsmedhjælpere N=64 & 6 & 28 & 38 & 25 & 3 \\
\hline Omsorg i forhold til hvad beboerne/ brugerne selv ønsker af udfordringer \\
\hline Alle N=235 & 11 & 38 & 31 & 16 & 3 \\
\hline Pædagoger N=172 & 11 & 40 & 30 & 17 & 2 \\
\hline Omsorgsmedhjælpere N=62 & 10 & 34 & 35 & 15 & 6 \\
\hline
\end{tabular}

Tabel 18. 'Vanskelig viden' om beboere/brugere, du er tilknyttet

\begin{tabular}{|c|c|c|c|c|}
\hline $\begin{array}{l}\text { 'Vanskelig viden' om be- } \\
\text { boere/ brugere, du er til- } \\
\text { knyttet }\end{array}$ & $\begin{array}{l}\text { Ofte } \\
\text { Antal i \% }\end{array}$ & $\begin{array}{l}\text { En gang i } \\
\text { mellem } \\
\text { Antal i \% }\end{array}$ & $\begin{array}{l}\text { Sjældent } \\
\text { Antal i \% }\end{array}$ & $\begin{array}{l}\text { Aldrig } \\
\text { Antal i \% }\end{array}$ \\
\hline \multicolumn{5}{|c|}{$\begin{array}{l}\text { Hvor ofte oplever du at få indsigt i beboere/ brugeres forhold, som du ikke } \\
\text { ved hvad du skal stille op med? }\end{array}$} \\
\hline Alle $\mathrm{N}=240$ & 6 & 35 & 50 & 8 \\
\hline Pædagoger $\mathrm{N}=173$ & 6 & 34 & 51 & 9 \\
\hline Omsorgsmedhjælpere $\mathrm{N}=65$ & 8 & 38 & 46 & 8 \\
\hline \multicolumn{5}{|c|}{$\begin{array}{l}\text { Hvor ofte oplever du problemer i forhold til dine beboere/ brugere, som du } \\
\text { ikke ved hvad du skal stille op med? }\end{array}$} \\
\hline Alle $\mathrm{N}=239$ & 8 & 41 & 46 & 5 \\
\hline Pædagoger $\mathrm{N}=173$ & 7 & 42 & 45 & 6 \\
\hline Omsorgsmedhjælpere $\mathrm{N}=64$ & 8 & 41 & 48 & 3 \\
\hline \multicolumn{5}{|c|}{$\begin{array}{l}\text { * Hvis du har svaret bekræftende til et af de to foregående spørgsmål, har } \\
\text { du da givet denne viden videre til din leder, men oplevet at informationen } \\
\text { ikke er blevet taget tilstrækkeligt alvorligt? }\end{array}$} \\
\hline Alle $\mathrm{N}=194$ & 11 & 19 & 22 & 48 \\
\hline Pædagoger $\mathrm{N}=140$ & 11 & 20 & 21 & 48 \\
\hline Omsorgsmedhjælpere $\mathrm{N}=52$ & 12 & 15 & 23 & 50 \\
\hline
\end{tabular}




\section{Trivsel på arbejdspladsen}

Tabel 19. Oplevelse af ledelse og organisering af bo-/dagtilbuddet

\begin{tabular}{|c|c|c|c|c|c|}
\hline $\begin{array}{l}\text { Oplevelse af ledelse og } \\
\text { organisering af bo- } \\
\text { / dagtilbuddet }\end{array}$ & Slet ikke & $\begin{array}{l}\text { I mindre } \\
\text { grad } \\
\text { Antal i \% }\end{array}$ & $\begin{array}{l}\text { I nogen } \\
\text { grad } \\
\text { Antal i \% }\end{array}$ & $\begin{array}{l}\text { I høj } \\
\text { grad } \\
\text { Antal i \% }\end{array}$ & \begin{tabular}{|l|} 
Ved ikke \\
l ønsker \\
ikke \\
at svare \\
Antal i \% \\
\end{tabular} \\
\hline \multicolumn{6}{|c|}{ Måden bo-/ dagtilbuddet som helhed ledes på er for uprofessionel } \\
\hline Alle $\mathrm{N}=241$ & 57 & 21 & 14 & 5 & 2 \\
\hline Pædagoger $\mathrm{N}=175$ & 8 & 21 & 15 & 4 & 2 \\
\hline Omsorgsmedhjælpere $\mathrm{N}=64$ & 53 & 23 & 13 & 6 & 5 \\
\hline \multicolumn{6}{|c|}{ Der er for langt fra 'gulvet' til ledelsen af bo-/ dagtilbuddet } \\
\hline Alle $\mathrm{N}=241$ & 51 & 27 & 15 & 6 & 2 \\
\hline $\mathrm{rN}=174$ & 55 & 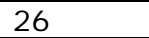 & 14 & 5 & 1 \\
\hline Omsorgsmedhjælpere $\mathrm{N}=65$ & 43 & 28 & 17 & 8 & 5 \\
\hline \multicolumn{6}{|c|}{$\begin{array}{l}\text { Der er for lidt selvstændighed (uddelegering af ansvaret) til de enkelte } \\
\text { enheder/ afdelinger på bo-/ dagtilbuddet }\end{array}$} \\
\hline Alle $\mathrm{N}=241$ & 71 & 15 & 8 & 2 & 4 \\
\hline Pædagoger $\mathrm{N}=175$ & 74 & 15 & 7 & 2 & 2 \\
\hline Omsorgsmedhjælpere $\mathrm{N}=64$ & 64 & 16 & 9 & 2 & 9 \\
\hline \multicolumn{6}{|c|}{$\begin{array}{l}\text { Organiseringen af bo-/ dagtilbuddet i de nuværende afdelinger/ enheder er } \\
\text { ikke så hensigtsmæssig, som den kunne være }\end{array}$} \\
\hline Alle $\mathrm{N}=237$ & 35 & 27 & 20 & 5 & 9 \\
\hline Pædagoger $\mathrm{N}=174$ & 35 & 33 & 20 & 5 & 7 \\
\hline Omsorgsmedhjælpere $\mathrm{N}=61$ & 36 & 23 & 18 & 8 & 15 \\
\hline \multicolumn{6}{|c|}{$\begin{array}{l}\text { Der er for lidt opmærksomhed omkring vigtigheden af at introduce- } \\
\text { re/ 'oplære' nye medarbejdere (fastansatte og vikarer) grundigt til deres } \\
\text { nye job }\end{array}$} \\
\hline Alle $\mathrm{N}=240$ & 47 & 25 & 18 & 8 & 2 \\
\hline Pædagoger $\mathrm{N}=173$ & 50 & 27 & 16 & 5 & 2 \\
\hline Omsorgsmedhjælpere $\mathrm{N}=65$ & 38 & 23 & 22 & 14 & 3 \\
\hline
\end{tabular}

Tabel 20. Oplevelse af det psykiske arbejdsmiljø som helhed.

\begin{tabular}{|l|l|l|l|}
\hline $\begin{array}{l}\text { Oplevelse af det psykiske } \\
\text { arbejdsmiljø som helhed }\end{array}$ & $\begin{array}{l}\text { Nej, ikke psykisk } \\
\text { belastende } \\
\text { Antal i \% }\end{array}$ & $\begin{array}{l}\text { Lidt psykisk } \\
\text { belastende } \\
\text { Antal i \% }\end{array}$ & $\begin{array}{l}\text { Noget eller me- } \\
\text { get } \\
\text { psykisk bela- } \\
\text { stende } \\
\text { Antal i \% }\end{array}$ \\
\hline Oplever du alt i alt at dit arbejde er psykisk belastende? \\
\hline Alle $\mathrm{N}=239$ & 14 & 59 & 27 \\
\hline Pædagoger $\mathrm{N}=173$ & 11 & 61 & 28 \\
\hline Omsorgsmedhjælpere $\mathrm{N}=64$ & 20 & 56 & 24 \\
\hline
\end{tabular}


Tabel 21. Belastende psykiske faktorer i arbejdet. Hvis du mener, at dit arbejde er lidt, noget eller meget psykisk belastende: I hvilken grad oplever du så, at nedenstående faktorer bidrager hertil?

\begin{tabular}{|c|c|c|c|c|c|}
\hline $\begin{array}{l}\text { Belastende psykiske fak- } \\
\text { torer i arbejdet }\end{array}$ & Slet ikke & $\begin{array}{l}\text { I mindre } \\
\text { grad }\end{array}$ & $\begin{array}{l}\text { I nogen } \\
\text { grad }\end{array}$ & $\begin{array}{l}\text { I } \\
\text { grad }\end{array}$ & \begin{tabular}{|l|} 
Denne \\
faktor er \\
ikke til \\
stede i \\
mit ar- \\
bejde \\
Antal i \% \\
\end{tabular} \\
\hline \multicolumn{6}{|c|}{ J eg er usikker på hvad der forventes af mig } \\
\hline Alle $\mathrm{N}=219$ & 51 & 34 & 13 & 1 & 0 \\
\hline Pædagoger $\mathrm{N}=160$ & 51 & 34 & 13 & 1 & 1 \\
\hline Omsorgsmedhjælpere $\mathrm{N}=57$ & 49 & 37 & 12 & 2 & 0 \\
\hline \multicolumn{6}{|c|}{ Egne høje krav til arbejdspræstation } \\
\hline Alle $\mathrm{N}=214$ & 19 & 24 & 32 & 24 & 0 \\
\hline Pædagoger $\mathrm{N}=156$ & 18 & 22 & 35 & 24 & 1 \\
\hline Omsorgsmedhjælpere $\mathrm{N}=56$ & 20 & 32 & 25 & 23 & 0 \\
\hline \multicolumn{6}{|c|}{ Samarbejde i personalegruppen } \\
\hline Alle $\mathrm{N}=217$ & 33 & 36 & 17 & 13 & 0 \\
\hline Pædagoger $\mathrm{N}=160$ & 31 & 37 & 19 & 13 & 0 \\
\hline Omsorgsmedhjælpere $\mathrm{N}=55$ & 38 & 36 & 11 & 15 & 0 \\
\hline \multicolumn{6}{|c|}{ Manglende anerkendelse fra anden faggruppe } \\
\hline Alle $\mathrm{N}=217$ & 53 & 22 & 12 & 4 & 8 \\
\hline Pædagoger $\mathrm{N}=159$ & 58 & 21 & 11 & 3 & 7 \\
\hline Omsorgsmedhjælpere $\mathrm{N}=56$ & 41 & 25 & 14 & 7 & 13 \\
\hline \multicolumn{6}{|c|}{ Mængden af arbejdsopgaver pr. dag } \\
\hline Alle $\mathrm{N}=218$ & 15 & 30 & 37 & 18 & 0 \\
\hline Pædagoger $\mathrm{N}=159$ & 11 & 30 & 38 & 21 & 0 \\
\hline Omsorgsmedhjælpere $\mathrm{N}=57$ & 26 & 32 & 33 & 9 & 0 \\
\hline \multicolumn{6}{|l|}{ Modstridende krav i arbejdet } \\
\hline Alle $\mathrm{N}=216$ & 26 & 36 & 25 & 12 & 1 \\
\hline Pædagoger $\mathrm{N}=159$ & 26 & 35 & 27 & 12 & 0 \\
\hline Omsorgsmedhjælpere $\mathrm{N}=55$ & 25 & 38 & 20 & 13 & 4 \\
\hline \multicolumn{6}{|c|}{ Vigtige beslutninger under tidspres } \\
\hline Alle $\mathrm{N}=218$ & 19 & 39 & 31 & 11 & 0 \\
\hline Pædagoger $\mathrm{N}=159$ & 16 & 36 & 35 & 13 & 0 \\
\hline Omsorgsmedhjælpere $\mathrm{N}=57$ & 26 & 46 & 21 & 5 & 2 \\
\hline \multicolumn{6}{|c|}{ Manglende fælles mål i arbejdet } \\
\hline Alle $\mathrm{N}=218$ & 32 & 35 & 24 & 9 & 0 \\
\hline Pædagoger $\mathrm{N}=159$ & 31 & 37 & 23 & 9 & 0 \\
\hline Omsorgsmedhjælpere $\mathrm{N}=57$ & 33 & 32 & 26 & 9 & 0 \\
\hline \multicolumn{6}{|c|}{ Manglende støtte og hjælp fra kolleger i belastede situationer } \\
\hline Alle $\mathrm{N}=220$ & 54 & 30 & 13 & 4 & 0 \\
\hline Pædagoger $\mathrm{N}=161$ & 53 & 30 & 14 & 3 & 0 \\
\hline Omsorgsmedhjælpere $\mathrm{N}=57$ & 53 & 30 & 11 & 10 & 0 \\
\hline \multicolumn{6}{|c|}{ Manglende mulighed for personlig udvikling i arbejdet } \\
\hline Alle $\mathrm{N}=220$ & 35 & 34 & 24 & 7 & 0 \\
\hline Pædagoger $\mathrm{N}=161$ & 35 & 33 & 25 & 7 & 0 \\
\hline Omsorgsmedhjælpere $\mathrm{N}=57$ & 33 & 37 & 23 & 7 & 0 \\
\hline \multicolumn{6}{|c|}{ At arbejdet ikke er tilstrækkelig interessant og spændende } \\
\hline Alle $\mathrm{N}=219$ & 54 & 31 & 13 & 2 & 0 \\
\hline Pædagoger $\mathrm{N}=161$ & 53 & 32 & 13 & 2 & 0 \\
\hline Omsorgsmedhjælpere $\mathrm{N}=56$ & 59 & 28 & 11 & 2 & 0 \\
\hline
\end{tabular}




\begin{tabular}{|c|c|c|c|c|c|}
\hline Alle $\mathrm{N}=216$ & 25 & 30 & 23 & 22 & 0 \\
\hline Pædagoger $\mathrm{N}=160$ & 24 & 29 & 24 & 23 & 0 \\
\hline Omsorgsmedhjælpere $\mathrm{N}=54$ & 26 & 32 & 22 & 20 & 0 \\
\hline \multicolumn{6}{|l|}{ Utryghed $\mathrm{i}$ ansættelse } \\
\hline Alle $\mathrm{N}=217$ & 77 & 13 & 7 & 2 & 0 \\
\hline Pædagoger $\mathrm{N}=159$ & 80 & 11 & 7 & 2 & 0 \\
\hline Omsorgsmedhjælpere $\mathrm{N}=56$ & 68 & 20 & 9 & 3 & 0 \\
\hline \multicolumn{6}{|c|}{$\begin{array}{l}\text { Svært at tolke beboerne/ brugernes ønsker og behov pga. kommunikati- } \\
\text { onsvanskeligheder }\end{array}$} \\
\hline Alle $\mathrm{N}=218$ & 22 & 41 & 27 & 10 & 0 \\
\hline Pædagoger $\mathrm{N}=159$ & 23 & 40 & 26 & 11 & 0 \\
\hline Omsorgsmedhjælpere $\mathrm{N}=57$ & 19 & 44 & 30 & 7 & 0 \\
\hline \multicolumn{6}{|c|}{ Beboerne/ brugerne kræver for meget } \\
\hline Alle $\mathrm{N}=219$ & 26 & 38 & 26 & 10 & 0 \\
\hline Pædagoger $\mathrm{N}=161$ & 25 & 37 & 28 & 10 & 0 \\
\hline Omsorgsmedhjælpere $\mathrm{N}=56$ & 28 & 43 & 20 & 9 & 0 \\
\hline \multicolumn{6}{|c|}{ Beboerne/ brugerne er urolige/ voldsomme } \\
\hline Alle $\mathrm{N}=218$ & 18 & 36 & 28 & 17 & 0 \\
\hline Pædagoger $\mathrm{N}=161$ & 20 & 33 & 29 & 17 & 1 \\
\hline Omsorgsmedhjælpere $\mathrm{N}=55$ & 15 & 45 & 25 & 15 & 0 \\
\hline \multicolumn{6}{|l|}{ Trusler om vold } \\
\hline Alle $\mathrm{N}=216$ & 35 & 37 & 17 & 10 & 0 \\
\hline Pædagoger $\mathrm{N}=159$ & 33 & 36 & 20 & 10 & 1 \\
\hline Omsorgsmedhjælpere $\mathrm{N}=55$ & 40 & 40 & 9 & 11 & 0 \\
\hline \multicolumn{6}{|l|}{ Udsat for vold } \\
\hline Alle $\mathrm{N}=218$ & 39 & 36 & 13 & 11 & 0 \\
\hline Pædagoger $\mathrm{N}=160$ & 37 & 38 & 14 & 10 & 1 \\
\hline Omsorgsmedhjælpere $\mathrm{N}=56$ & 45 & 30 & 11 & 14 & 0 \\
\hline \multicolumn{6}{|l|}{ Pårørende kræver for meget } \\
\hline Alle $\mathrm{N}=220$ & 40 & 33 & 16 & 8 & 3 \\
\hline Pædagoger $\mathrm{N}=161$ & 40 & 34 & 17 & 7 & 2 \\
\hline Omsorgsmedhjælpere $\mathrm{N}=57$ & 39 & 32 & 14 & 9 & 7 \\
\hline \multicolumn{6}{|l|}{ Andet. Evt. hvilke: $*$} \\
\hline Alle $\mathrm{N}=11$ & 0 & 18 & 18 & 55 & 9 \\
\hline Pædagoger $\mathrm{N}=4$ & 0 & 25 & 0 & 75 & \\
\hline Omsorgsmedhjælpere $\mathrm{N}=7$ & 14 & 29 & 43 & 14 & \\
\hline
\end{tabular}

* Blandt skriftlige kommentarer under 'Andet' er: Den store fokusering på selv og medbestemmelse til beboerne harmonerer ikke til personer med de problemstillinger som vores beboere har (voksne fysisk, psykisk og udviklingshæmmede). Udadreagerende adfærd, Konflikter mellem beboerne som pers. Må løse. For lav normering. Få hænder går for meget på kompromis med pædagogiske opgaver

Tabel 22. Oplevelse af det fysiske arbejdsmiljø som helhed

\begin{tabular}{|l|l|l|l|}
\hline $\begin{array}{l}\text { Oplevelse af det fysiske } \\
\text { arbejdsmiljø som helhed }\end{array}$ & $\begin{array}{l}\text { Nej, ikke } \\
\text { fysisk } \\
\text { belastende } \\
\text { Antal } \mathrm{i} \%\end{array}$ & $\begin{array}{l}\text { Lidt fysisk } \\
\text { Belastende } \\
\text { Antal i \% }\end{array}$ & $\begin{array}{l}\text { Noget eller me- } \\
\text { get fysisk bela- } \\
\text { stende } \\
\text { Antal i \% }\end{array}$ \\
\hline \multicolumn{2}{|l|}{ Oplever du alt i alt at dit arbejde er fysisk belastende? } \\
\hline Alle $\mathrm{N}=239$ & 35 & 40 & 25 \\
\hline Pædagoger $\mathrm{N}=173$ & 35 & 41 & 24 \\
\hline Omsorgsmedhjælpere $\mathrm{N}=64$ & 33 & 37 & 30 \\
\hline
\end{tabular}


Tabel 23. Forekommer nogle af de nedenstående faktorer i generende grad i dit arbejde

\begin{tabular}{|c|c|c|c|c|}
\hline $\begin{array}{l}\text { Forekommer nogle af de } \\
\text { nedenstående faktorer i } \\
\text { generende grad i dit ar- } \\
\text { bejde? }\end{array}$ & $\begin{array}{l}\text { Ja } \\
\text { Antal i \% }\end{array}$ & $\begin{array}{l}\text { Nej } \\
\text { Antal i \% }\end{array}$ & $\begin{array}{l}\text { Ved ikke } \\
\text { Antal i \% }\end{array}$ & $\begin{array}{l}\text { Denne faktor } \\
\text { er } \\
\text { ikke relevant } \\
\text { for mig } \\
\text { Antal i \% } \\
\end{array}$ \\
\hline \multicolumn{5}{|c|}{ Tunge løft eller andre belastende arbejdsstillinger eller bevægelser } \\
\hline Alle $\mathrm{N}=233$ & 56 & 36 & 2 & 6 \\
\hline Pædagoger $\mathrm{N}=169$ & 54 & 37 & 1 & 8 \\
\hline Omsorgsmedhjælpere $\mathrm{N}=62$ & 61 & 34 & 3 & 2 \\
\hline \multicolumn{5}{|l|}{ For små arbejdslokaler } \\
\hline Alle $\mathrm{N}=230$ & 58 & 37 & 2 & 3 \\
\hline Pædagoger $\mathrm{N}=166$ & 59 & 35 & 2 & 4 \\
\hline Omsorgsmedhjælpere $\mathrm{N}=62$ & 55 & 42 & 3 & 0 \\
\hline \multicolumn{5}{|c|}{ For mange personer i samme rum } \\
\hline Alle $\mathrm{N}=230$ & 53 & 39 & 5 & 2 \\
\hline Pædagoger $\mathrm{N}=166$ & 54 & 37 & 6 & 3 \\
\hline Omsorgsmedhjælpere $\mathrm{N}=62$ & 52 & 43 & 5 & 0 \\
\hline \multicolumn{5}{|l|}{ Dårlig ventilation } \\
\hline Alle $\mathrm{N}=233$ & 50 & 42 & 6 & 2 \\
\hline Pædagoger $\mathrm{N}=171$ & 51 & 40 & 6 & 3 \\
\hline Omsorgsmedhjælpere $\mathrm{N}=60$ & 48 & 47 & 5 & 0 \\
\hline \multicolumn{5}{|c|}{ Forstyrrende lyde, megen støj } \\
\hline Alle $\mathrm{N}=233$ & 61 & 36 & 3 & 1 \\
\hline Pædagoger $\mathrm{N}=169$ & 64 & 32 & 2 & 2 \\
\hline Omsorgsmedhjælpere N=62 & 53 & 42 & 5 & 0 \\
\hline \multicolumn{5}{|c|}{ Temperaturforhold (varme/ kulde) } \\
\hline Alle $\mathrm{N}=233$ & 41 & 52 & 6 & 1 \\
\hline Pædagoger $\mathrm{N}=169$ & 42 & 52 & 5 & 1 \\
\hline Omsorgsmedhjælpere $\mathrm{N}=62$ & 39 & 53 & 6 & 2 \\
\hline \multicolumn{5}{|l|}{ Træk i lokalet } \\
\hline Alle $\mathrm{N}=232$ & 29 & 61 & 8 & 1 \\
\hline Pædagoger $\mathrm{N}=168$ & 32 & 59 & 8 & 1 \\
\hline Omsorgsmedhjælpere $\mathrm{N}=62$ & 22 & 66 & 10 & 2 \\
\hline \multicolumn{5}{|l|}{ Tør luft } \\
\hline Alle $\mathrm{N}=234$ & 36 & 51 & 12 & 1 \\
\hline Pædagoger $\mathrm{N}=170$ & 38 & 49 & 12 & 1 \\
\hline Omsorgsmedhjælpere $\mathrm{N}=63$ & 32 & 55 & 11 & 2 \\
\hline \multicolumn{5}{|l|}{ Mangelfuld rengøring } \\
\hline Alle $\mathrm{N}=233$ & 40 & 56 & 3 & 0 \\
\hline Pædagoger $\mathrm{N}=170$ & 40 & 56 & 3 & 1 \\
\hline Omsorgsmedhjælpere $\mathrm{N}=61$ & 41 & 54 & 5 & 0 \\
\hline \multicolumn{5}{|c|}{ Ingen eller for få personalerum } \\
\hline Alle $\mathrm{N}=232$ & 45 & 52 & 2 & 1 \\
\hline Pædagoger $\mathrm{N}=168$ & 47 & 50 & 2 & 1 \\
\hline Omsorgsmedhjælpere $\mathrm{N}=62$ & 40 & 56 & 2 & 2 \\
\hline \multicolumn{5}{|l|}{ For ringe sanitære forhold } \\
\hline Alle $\mathrm{N}=231$ & 40 & 55 & 5 & 0 \\
\hline Pædagoger $\mathrm{N}=169$ & 42 & 54 & 4 & 0 \\
\hline Omsorgsmedhjælpere $\mathrm{N}=60$ & 35 & 55 & 10 & 0 \\
\hline \multicolumn{5}{|l|}{ Andet, da hvilket: * } \\
\hline Alle $\mathrm{N}=14$ & 79 & 14 & 7 & 0 \\
\hline Pædagoger $\mathrm{N}=11$ & 91 & 0 & 9 & \\
\hline Omsorgsmedhjælpere $\mathrm{N}=3$ & 33 & 67 & 0 & \\
\hline
\end{tabular}


* Kommentarer under 'Andet': Sammenblanding af personalefaciliteter og beboer opholdssted. Få baderum, meget vasketøj. Fysiske rammer der ikke matcher opgaven

Tabel 24. Er du alt i alt tilfreds med dit nuværende arbejde?

\begin{tabular}{|c|c|c|c|c|}
\hline $\begin{array}{l}\text { Er du alt i alt tilfreds med } \\
\text { dit nuværende arbejde? }\end{array}$ & $\begin{array}{l}\text { Ja, i høj } \\
\text { grad } \\
\text { Antal i \% }\end{array}$ & $\begin{array}{l}\text { Ja, i nogen } \\
\text { grad } \\
\text { Antal i \% }\end{array}$ & $\begin{array}{l}\text { Nej, } \\
\text { kun i min- } \\
\text { dre grad } \\
\text { Antal i \% }\end{array}$ & $\begin{array}{l}\text { Nej, slet } \\
\text { I kke } \\
\text { Antal i \% }\end{array}$ \\
\hline \multicolumn{5}{|c|}{ Det daglige arbejde med beboerne/ brugerne } \\
\hline Alle $\mathrm{N}=239$ & 63 & 30 & 6 & 1 \\
\hline Pædagoger $\mathrm{N}=173$ & 65 & 28 & 6 & 1 \\
\hline Omsorgsmedhjælpere $\mathrm{N}=64$ & 59 & 34 & 6 & 0 \\
\hline \multicolumn{5}{|l|}{ Arbejdsbetingelserne } \\
\hline Alle $\mathrm{N}=238$ & 36 & 46 & 16 & 2 \\
\hline Pædagoger $\mathrm{N}=172$ & 36 & 45 & 17 & 2 \\
\hline Omsorgsmedhjælpere $\mathrm{N}=64$ & 36 & 48 & 14 & 2 \\
\hline
\end{tabular}

Eventuel kommentar til trivsel på arbejdspladsen: 24 svar fra pædagoger og 6 fra omsorgsmedhjælpere. Alt for meget arbejde og for lidt tid. Vi har meget travlt, mange arbejdsopgaver. Men vi får en bedre og bedre kontakt i teamet. For dårlig normering. Antallet af medhjælpere er steget voldsomt og øger byrden på de fagligt uddannede. Lønnen adskiller sig ikke fra almenområdet - hvorfor risikere vold? 


\section{Synspunkter på den pædagogiske indsats}

Tabel 25. Synspunkter på den pædagogiske dagligdag

I det følgende kommer en række udsagn om den daglige pædagogiske indsats på boenheden/afdelingen du er tilknyttet, som du bedes tage stilling til

\begin{tabular}{|l|l|l|l|l|l|}
\hline $\begin{array}{l}\text { Synspunkter på den pæ- } \\
\text { dagogiske dagligdag }\end{array}$ & $\begin{array}{l}\text { Helt } \\
\text { enig } \\
\text { Antal i \% }\end{array}$ & $\begin{array}{l}\text { Delvis } \\
\text { enig } \\
\text { Antal i \% }\end{array}$ & $\begin{array}{l}\text { Uenig } \\
\text { Antal i \% }\end{array}$ & $\begin{array}{l}\text { Helt } \\
\text { uenig } \\
\text { Antal i \% }\end{array}$ & $\begin{array}{l}\text { Ved } \\
\text { ikke } \\
\text { Antal i \% }\end{array}$ \\
\hline
\end{tabular}

I almindelighed er der den nødvendige tid til den daglige omsorg $\mathrm{i}$ forhold til de enkelte beboere/ brugere

\begin{tabular}{|l|l|l|l|l|l|}
\hline Alle $\mathrm{N}=239$ & 23 & 49 & 22 & 6 & 1 \\
\hline Pædagoger $\mathrm{N}=173$ & 22 & 49 & 23 & 6 & 0 \\
\hline Omsorgsmedhjælpere $\mathrm{N}=64$ & 23 & 47 & 19 & 8 & 3 \\
\hline
\end{tabular}

I dagligdagen tages der tilpas hensyn til den enkelte beboer/ brugers individuelle ønsker mht. mad, privatliv, mv.

\begin{tabular}{|l|l|l|l|l|l|}
\hline Alle $\mathrm{N}=240$ & 30 & 52 & 13 & 5 & 0 \\
\hline Pædagoger $\mathrm{N}=174$ & 31 & 53 & 13 & 3 & 0 \\
\hline Omsorgsmedhjælpere $\mathrm{N}=64$ & 28 & 47 & 16 & 8 & 1 \\
\hline
\end{tabular}

På bostedet/ afdelingen tages der tilstrækkeligt hensyn til de enkelte beboeres/ brugeres individuelle livsrytmer og daglige rutiner

\begin{tabular}{|l|l|l|l|l|l|}
\hline Alle $\mathrm{N}=238$ & 36 & 50 & 11 & 3 & 1 \\
\hline Pædagoger $\mathrm{N}=173$ & 34 & 54 & 9 & 2 & 1 \\
\hline Omsorgsmedhjælpere $\mathrm{N}=63$ & 38 & 41 & 14 & 5 & 2
\end{tabular}

Beboerne/ brugere synes, at der godt måtte være flere aktiviteter ud af huset ( byture, udflugter, m.v.)

\begin{tabular}{|l|l|l|l|l|l|}
\hline Alle $\mathrm{N}=236$ & 33 & 35 & 14 & 2 & 16 \\
\hline Pædagoger $\mathrm{N}=172$ & 33 & 39 & 13 & 2 & 13 \\
\hline Omsorgsmedhjælpere $\mathrm{N}=62$ & 34 & 24 & 16 & 2 & 24
\end{tabular}

Beboerne/ brugerne er alle eller næsten alle Glade for det dagtilbud, de er tilknyttet

\begin{tabular}{|l|l|l|l|l|l|}
\hline Alle N=234 & 46 & 38 & 4 & 1 & 12 \\
\hline Pædagoger N=169 & 46 & 40 & 4 & 1 & 9 \\
\hline Omsorgsmedhjælpere N=63 & 48 & 30 & 3 & 0 & 19 \\
\hline
\end{tabular}

Samarbejde og praktisk koordinering mellem bostedet og dagtilbuddene fungerer i det daglige godt

Alle $\mathrm{N}=236$

Pædagoger $\mathrm{N}=171$

Omsorgsmedhjælpere $\mathrm{N}=63$

\begin{tabular}{|l|l|l|l|l|}
\hline 36 & 52 & 7 & 1 & 4 \\
\hline 39 & 50 & 7 & 1 & 3 \\
\hline 30 & 56 & 6 & 2 & 6 \\
\hline
\end{tabular}

De beboere/ brugere, der lige nu er på bostedet/ dagtilbuddet, fungerer som helhed godt sammen med hinanden i dagligdagen

\begin{tabular}{|l|l|l|l|l|l|}
\hline Alle $\mathrm{N}=233$ & 17 & 42 & 25 & 14 & 2 \\
\hline Pædagoger $\mathrm{N}=168$ & 16 & 39 & 28 & 15 & 2 \\
\hline Omsorgsmedhjælpere $\mathrm{N}=63$ & 20 & 51 & 16 & 11 & 2 \\
\hline
\end{tabular}

I almindelighed er der en god balance mellem

fast gennemgående personale og tilkaldevikarer

Alle $\mathrm{N}=236$

\begin{tabular}{|l|l|l}
\hline Pædagoger $\mathrm{N}=172$ & 47 \\
\hline
\end{tabular}

\begin{tabular}{l|l|l}
\hline Omsorgsmedhjælpere $\mathrm{N}=62$ & 45 \\
\hline
\end{tabular}

\begin{tabular}{|l|l|}
39 & 10 \\
40 & 10 \\
\hline 37 & 10
\end{tabular}

Der er for ofte perioder, hvor sygdom, ubesatte stillinger o.a. medfører et for stort gennemtræk af vikarer på bostedet/ afdelingen i dagligdagen

\begin{tabular}{|l|l|l|l|l|l|}
\hline Alle $\mathrm{N}=234$ & 27 & 31 & 23 & 15 & 4 \\
\hline Pædagoger N=170 & 27 & 28 & 24 & 17 & 4 \\
\hline Omsorgsmedhjælpere N=62 & 29 & 39 & 18 & 9 & 5 \\
\hline
\end{tabular}

Pårørende til beboere/ brugere påskønner alle eller næsten alle den ind- 
sats, vi yder i dagligdagen

Alle $\mathrm{N}=234$

Pædagoger $\mathrm{N}=170$

38

Omsorgsmedhjælpere $\mathrm{N}=62 \quad 28$

\begin{tabular}{l|l}
42 & 45 \\
\hline & 52
\end{tabular}

47

7

\begin{tabular}{|l|l}
2 & 6 \\
3 & 5 \\
2 & 27 \\
\hline
\end{tabular}

Det er meget sjældent, personalet oplever at komme i situationer, hvor de må overveje eventuelt at bruge fysisk magtanvendelse

Alle $\mathrm{N}=237$

Pædagoger $\mathrm{N}=172$

\begin{tabular}{|l|l|}
47 & 30 \\
\hline 48 & 32 \\
\hline
\end{tabular}

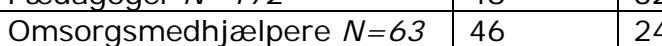

I dagligdagen oplever personalet ofte 'etiske dilemmaer' mellem forskellige pædagogiske hensyn ift. den enkelte beboer/bruger (f.eks. beboer/ brugers krav om 'usund mad' og pædagogisk omsorgspligt)

\begin{tabular}{|l|l|l|l|l|l|}
\hline Alle $\mathrm{N}=237$ & 37 & 41 & 11 & 3 & 8 \\
\hline Pædagoger N=172 & 40 & 44 & 10 & 2 & 4 \\
\hline Omsorgsmedhjælpere N=63 & 32 & 32 & 13 & 6 & 17 \\
\hline
\end{tabular}

Tabel 26. Pædagogisk 'vanskelige situationer'. Nedenfor er nævnt en række situationstyper, hvor du bedes svare, om du i dagligdagen i din boenhed/afdeling her oplever 'pædagogisk vanskelige situationer'

\begin{tabular}{|c|c|c|c|c|c|c|}
\hline $\begin{array}{l}\text { Pædagogisk } \\
\text { 'vanskelige situationer' }\end{array}$ & $\begin{array}{l}\begin{array}{l}\text { Meget } \\
\text { ofte }\end{array} \\
\text { Antal } \\
i \% \\
\end{array}$ & $\begin{array}{l}\text { Ofte } \\
\text { Antal } \\
i \% \\
\end{array}$ & $\begin{array}{l}\begin{array}{l}\text { Sjæl- } \\
\text { dent }\end{array} \\
\text { Antal } \\
\text { i \% }\end{array}$ & $\begin{array}{l}\text { Meget } \\
\text { sjæl- } \\
\text { dent } \\
\text { Antal } \\
\mathrm{i} \% \\
\end{array}$ & $\begin{array}{l}\begin{array}{l}\text { Ved } \\
\text { ikke }\end{array} \\
\text { Antal } \\
i \%\end{array}$ & \begin{tabular}{|l|} 
I kke \\
aktuelt \\
for mig \\
Antal \\
i $\%$ \\
\end{tabular} \\
\hline
\end{tabular}

Måltiderne (eksempelvis beboere/ brugere, som ikke vil spise det, der er på bordet, går til og fra bordet o.I.)

\begin{tabular}{|l|l|l|l|l|l|l|}
\hline Alle $\mathrm{N}=237$ & 6 & 20 & 37 & 24 & 1 & 12 \\
\hline Pædagoger $\mathrm{N}=173$ & 5 & 20 & 38 & 23 & 1 & 13 \\
\hline Omsorgsmedhjælpere $\mathrm{N}=62$ & 8 & 21 & 37 & 22 & 2 & 10
\end{tabular}

Beboer/ brugerønsker om mad m.v. 'mellem måltiderne', som ikke kan imødekommes

Alle $\mathrm{N}=238$

Pædagoger $\mathrm{N}=172$

\begin{tabular}{|l|l|l|}
5 & 11 & 38 \\
\hline 4 & 10 & 41 \\
\hline
\end{tabular}

Omsorgsmedhjælpere $\mathrm{N}=64$

\begin{tabular}{l|l}
14 & 33 \\
\hline
\end{tabular}

\begin{tabular}{|l|l|l|l|}
38 & 27 & 3 & 16 \\
\hline 41 & 27 & 2 & 16 \\
\hline 33 & 27 & 3 & 14
\end{tabular}

Gå i seng situationer (eksempelvis hvis beboeren ikke vil gå i seng)

Alle $\mathrm{N}=239$

Pædagoger $\mathrm{N}=173$

\begin{tabular}{|l|l|l|}
\hline 2 & 10 & 38 \\
1 & 10 & 38 \\
5 & 9 & 39
\end{tabular}

\begin{tabular}{l|l}
38 & 27 \\
\hline 38 & 24 \\
39 & 36 \\
\hline
\end{tabular}

27

\begin{tabular}{|l|l|}
1 & 21 \\
1 & 26 \\
3 & 8
\end{tabular}

Stå op situationer (eksempelvis hvis beboeren ikke vil stå op)

\begin{tabular}{|l|l|l|l|l|l|l|}
\hline Alle N=235 & 2 & 16 & 40 & 29 & 1 & 14 \\
\hline Pædagoger N=171 & 2 & 14 & 39 & 29 & 1 & 16 \\
\hline Omsorgsmedhjelpere N=62 & 2 & 19 & 44 & 27 & 2 & 6
\end{tabular}

'Nattevandringer' (eksempelvis står op midt om natten og forstyrrer andre beboere)

Alle $\mathrm{N}=237$

Pædagoger $\mathrm{N}=172$

Omsorgsmedhjælpere $\mathrm{N}=63$ 3

\begin{tabular}{|l|l|l|}
2 & 15 & 29 \\
\hline 1 & 14 & 26 \\
\hline 3 & 17 & 37
\end{tabular}

\begin{tabular}{l|l|l|l|}
29 & 22 & 7 & 26 \\
26 & 22 & 8 & 29 \\
\hline 37 & 22 & 5 & 16
\end{tabular}

Modstand mod hygiejneomsorg (bade, børste tænder m.m. sammen med beboeren)

\begin{tabular}{|c|c|c|c|c|c|c|}
\hline Alle $\mathrm{N}=239$ & 5 & 23 & 38 & 26 & 1 & 7 \\
\hline Pædagoger $\mathrm{N}=173$ & 6 & 23 & 36 & 27 & 1 & 7 \\
\hline Omsorgsmedhjælpere $\mathrm{N}=64$ & 3 & 27 & 42 & 23 & 2 & 3 \\
\hline \multicolumn{7}{|c|}{ Modstand mod at tage lægeordineret medicin } \\
\hline Alle $\mathrm{N}=236$ & 2 & 5 & 33 & 47 & 3 & 9 \\
\hline
\end{tabular}




\begin{tabular}{|c|c|c|c|c|c|c|}
\hline Pædagoger $\mathrm{N}=171$ & 2 & 6 & 32 & 46 & 2 & 11 \\
\hline Omsorgsmedhjælpere $\mathrm{N}=63$ & 2 & 2 & 36 & 52 & 5 & 3 \\
\hline \multicolumn{7}{|c|}{$\begin{array}{l}\text { Beboere/ brugere som kræver at få udleveret egne penge, som vurderes vil } \\
\text { blive 'klattet væk' }\end{array}$} \\
\hline Alle $\mathrm{N}=236$ & 2 & 8 & 22 & 34 & 4 & 30 \\
\hline Pædagoger $\mathrm{N}=172$ & 2 & 9 & 23 & 33 & 3 & 30 \\
\hline Omsorgsmedhjælpere $\mathrm{N}=62$ & 2 & 5 & 21 & 35 & 8 & 29 \\
\hline \multicolumn{7}{|c|}{$\begin{array}{l}\text { Konflikter eller optræk til konflikter mellem beboere/ brugere som kræver } \\
\text { pædagogisk indgriben }\end{array}$} \\
\hline Alle $\mathrm{N}=236$ & 18 & 33 & 31 & 15 & 0 & 3 \\
\hline Pædagoger $\mathrm{N}=172$ & 20 & 32 & 30 & 14 & 1 & 3 \\
\hline Omsorgsmedhjælpere $\mathrm{N}=62$ & 11 & 34 & 32 & 20 & 0 & 3 \\
\hline \multicolumn{7}{|c|}{ Beboere/ brugere som er aggressive og svære at fà dæmpet ned } \\
\hline Alle $\mathrm{N}=237$ & 9 & 32 & 37 & 17 & 1 & 4 \\
\hline Pædagoger $\mathrm{N}=172$ & 10 & 34 & 33 & 17 & 1 & 5 \\
\hline Omsorgsmedhjælpere $\mathrm{N}=63$ & 8 & 25 & 48 & 17 & 0 & 2 \\
\hline \multicolumn{7}{|c|}{ Beboerne, som isolerer sig alt for meget på eget værelse/ lejlighed } \\
\hline Alle $\mathrm{N}=238$ & 7 & 30 & 39 & 14 & 1 & 9 \\
\hline Pædagoger $\mathrm{N}=172$ & 8 & 31 & 36 & 14 & 1 & 10 \\
\hline Omsorgsmedhjælpere $\mathrm{N}=64$ & 5 & 25 & 45 & 15 & 2 & 8 \\
\hline \multicolumn{7}{|c|}{ Fysiske konflikter mellem en beboer/ bruger og personale } \\
\hline Alle $\mathrm{N}=235$ & 4 & 15 & 37 & 32 & 1 & 10 \\
\hline Pædagoger $\mathrm{N}=170$ & 4 & 14 & 37 & 33 & 1 & 11 \\
\hline Omsorgsmedhjælpere $\mathrm{N}=63$ & 5 & 17 & 37 & 32 & 3 & 6 \\
\hline \multicolumn{7}{|c|}{ Beboere/ brugere, som tiltager sig 'urimelige rettigheder' i fællesarealerne } \\
\hline Alle $\mathrm{N}=237$ & 11 & 27 & 35 & 18 & 3 & 6 \\
\hline Pædagoger $\mathrm{N}=173$ & 12 & 26 & 36 & 17 & 2 & 7 \\
\hline Omsorgsmedhjælpere $\mathrm{N}=62$ & 8 & 29 & 31 & 23 & 6 & 3 \\
\hline \multicolumn{7}{|c|}{$\begin{array}{l}\text { Beboere/ brugere som virker kede af det eller vrede, men er svære at } \\
\text { komme i dialog med herom }\end{array}$} \\
\hline Alle $\mathrm{N}=238$ & 7 & 30 & 42 & 16 & 2 & 4 \\
\hline Pædagoger $\mathrm{N}=172$ & 7 & 29 & 42 & 16 & 1 & 5 \\
\hline Omsorgsmedhjælpere $\mathrm{N}=64$ & 6 & 27 & 45 & 16 & 3 & 3 \\
\hline \multicolumn{7}{|c|}{$\begin{array}{l}\text { Beboere/ brugere som virker 'fraværende' (apatiske) og er svære at kom- } \\
\text { me i kontakt med }\end{array}$} \\
\hline Alle $\mathrm{N}=235$ & 3 & 24 & 41 & 21 & 1 & \begin{tabular}{|l|}
10 \\
\end{tabular} \\
\hline Pædagoger $\mathrm{N}=170$ & 3 & 20 & 42 & 23 & 1 & \begin{tabular}{|l}
11 \\
\end{tabular} \\
\hline Omsorgsmedhjælpere $\mathrm{N}=63$ & 3 & 33 & 38 & 18 & 2 & 6 \\
\hline \multicolumn{7}{|c|}{ Beboere/ brugere som fysisk skader sig selv ('selvskadende virksomhed') } \\
\hline Alle $\mathrm{N}=235$ & 5 & 23 & 32 & 26 & 0 & 14 \\
\hline Pædagoger $\mathrm{N}=170$ & 3 & 23 & 31 & 25 & 1 & \begin{tabular}{|l}
17 \\
\end{tabular} \\
\hline Omsorgsmedhjælpere $\mathrm{N}=63$ & 10 & 19 & 36 & 30 & 0 & 5 \\
\hline \multicolumn{7}{|c|}{ Pårørende som udtrykker forventninger/ krav, der ikke kan indfries } \\
\hline Alle $\mathrm{N}=236$ & 3 & 16 & 39 & 25 & 9 & 9 \\
\hline Pædagoger $\mathrm{N}=170$ & 3 & 17 & 40 & 27 & 5 & 8 \\
\hline Omsorgsmedhjælpere $\mathrm{N}=64$ & 2 & 14 & 37 & 16 & 19 & 12 \\
\hline
\end{tabular}


Tabel 27. Udviklingsinitiativer generelt indenfor bo- og dagtilbud

\begin{tabular}{|l|l|l|l|}
\hline $\begin{array}{l}\text { Udviklingsinitiativer generelt in- } \\
\text { den for bo- og dagtilbud } \\
\text { Prioritering } \\
\text { Hvilke 2 af nedenstånde 6 mulige ind- } \\
\text { satsområder til styrkelse af bo- og dagtil- } \\
\text { bud mener du bør proriteres højest ud fra } \\
\text { dit kendskab til området som helhed? }\end{array}$ & $\begin{array}{l}\text { Omsorgs- } \\
\text { medhjæl- } \\
\text { pere }\end{array}$ & Alle \\
\hline $\begin{array}{l}\text { Faglighed, kompetenceudvikling og } \\
\text { efteruddannelse }\end{array}$ & 1 & 1 & $\begin{array}{l}1 \\
(40 \%)\end{array}$ \\
\hline $\begin{array}{l}\text { Pædagogisk udvikling, holdninger og } \\
\text { værdier }\end{array}$ & 2 & 2 & $\begin{array}{l}2 \\
(36 \%)\end{array}$ \\
\hline Rekruttering og introduktion & 5 & 3 & $\begin{array}{l}3 \\
(6 \%)\end{array}$ \\
\hline Arbejdets organisering & 6 & $\begin{array}{l}4 \\
(6 \%)\end{array}$ \\
\hline Ledelsesudvikling & 3 & $\begin{array}{l}6 \\
(5 \%)\end{array}$ \\
\hline Bruger- og pårørendeinddragelse & 4 & 5 & $\begin{array}{l}5 \\
(6 \%)\end{array}$ \\
\hline
\end{tabular}




\section{Uddannelsesprofil og tidligere arbejdserfaringer}

Tabel 28. Pædagogisk uddannelse

\begin{tabular}{|l|l|l|}
\hline $\begin{array}{l}\text { Har du pædagogisk uddan- } \\
\text { nelse? }\end{array}$ & $\begin{array}{l}\text { Ja } \\
\text { Antal i \% }\end{array}$ & $\begin{array}{l}\text { Nej } \\
\text { Antal i \% }\end{array}$ \\
\hline Alle $\mathrm{N}=234$ & 77 & 23 \\
\hline Pædagoger $\mathrm{N}=171$ & 99 & 1 \\
\hline Omsorgsmedhjælpere $\mathrm{N}=61$ & 18 & 82 \\
\hline
\end{tabular}

Tabel 28A. Pædagogisk uddannelse

\begin{tabular}{|c|c|c|}
\hline Pædagogisk uddannelse & $\begin{array}{l}\text { Ja } \\
\text { Faktisk antal }(\mathrm{N}=)\end{array}$ & $\begin{array}{l}\text { Ja } \\
\text { Andel af de deltagende } \\
\text { medarbejdergrupperinger } \\
\mathrm{i} \%\end{array}$ \\
\hline \multicolumn{3}{|c|}{ Uddannet pædagog/ socialpædagog } \\
\hline Alle & 165 & 68 \\
\hline Pædagoger & 163 & 93 \\
\hline Omsorgsmedhjælpere & 2 & 3 \\
\hline \multicolumn{3}{|c|}{ Pædagogisk Grunduddannelse (PGU) } \\
\hline Alle & 6 & 2 \\
\hline Pædagoger & 2 & 1 \\
\hline Omsorgsmedhjælpere & 4 & 6 \\
\hline \multicolumn{3}{|l|}{ Læreruddannelse } \\
\hline Alle & 4 & 2 \\
\hline Pædagoger & 3 & 2 \\
\hline Omsorgsmedhjælpere & 1 & 2 \\
\hline \multicolumn{3}{|c|}{ Cand.pæd., master eller lignende uddannelse } \\
\hline Alle & 4 & 2 \\
\hline Pædagoger & 3 & 2 \\
\hline Omsorgsmedhjælpere & 1 & 2 \\
\hline \multicolumn{3}{|c|}{$\begin{array}{l}\text { Anden pædagogik uddannelse, da hvilken? (omsorgsassistent nævnes af } \\
\text { flere) }\end{array}$} \\
\hline Alle & 21 & 9 \\
\hline Pædagoger & 15 & 9 \\
\hline Omsorgsmedhjælpere & 6 & 9 \\
\hline
\end{tabular}

Tabel 29. Anden uddannelse end en pædagogisk uddannelse.

\begin{tabular}{|l|l|l|}
\hline $\begin{array}{l}\text { Har du en anden uddannelse end en } \\
\text { pædagogisk uddannelse? }\end{array}$ & $\begin{array}{l}\text { Ja } \\
\text { Antal i \% }\end{array}$ & $\begin{array}{l}\text { Nej } \\
\text { Antal i \% }\end{array}$ \\
\hline Alle $\mathrm{N}=227$ & 38 & 62 \\
\hline Pædagoger $\mathrm{N}=165$ & 33 & 67 \\
\hline Omsorgsmedhjælpere $\mathrm{N}=60$ & 50 & 50 \\
\hline
\end{tabular}


Tabel 29A. Art af anden uddannelse.

\begin{tabular}{|l|l|l|}
\hline $\begin{array}{l}\text { Hvis ja til anden uddannelse, } \\
\text { hvilken uddannelse er der da tale } \\
\text { om? }\end{array}$ & $\begin{array}{l}\text { Ja } \\
\text { Faktisk antal } \\
(\mathrm{N}=)\end{array}$ & $\begin{array}{l}\text { Ja } \\
\text { Andel af de deltagende } \\
\text { medarbejdergrupperinger } \\
\text { i \% }\end{array}$ \\
\hline \multicolumn{2}{|l|}{ Lang videregående uddannelse (eks. universitetsuddannelse) } \\
\hline Alle & 15 & 6 \\
\hline Pædagoger & 8 & 5 \\
\hline Omsorgsmedhjælpere & 7 & 11 \\
\hline Mellemlang videregående uddannelse (eks. sygeplejerske) \\
\hline Alle & 7 & 3 \\
\hline Pædagoger & 2 & 1 \\
\hline Omsorgsmedhjælpere & 5 & 8 \\
\hline Handels-/ kontor-/ service-/ håndværkeruddannelse & $\mathbf{0 . l}$ \\
\hline Alle & 31 & 13 \\
\hline Pædagoger & 22 & 13 \\
\hline Omsorgsmedhjælpere & 9 & 14 \\
\hline Social- og Sundhedsassistent (SoSu) & \multicolumn{2}{|l|}{} \\
\hline Alle & 8 & 3 \\
\hline Pædagoger & 5 & 3 \\
\hline Omsorgsmedhjælpere & 3 & 5 \\
\hline Anden uddannelse $*$ & 35 & 14 \\
\hline Alle & 26 & 15 \\
\hline Pædagoger & 9 & 14 \\
\hline Omsorgsmedhjælpere &
\end{tabular}

* Under 'Anden uddannelse' nævnes eksempelvis sygehjælper, zoneterapeut, psykoterapeut, NLP-massør.

Tabel 29B. Om den anden uddannelse opleves at kunne bruges i det pædagogiske arbejde

\begin{tabular}{|l|l|l|l|}
\hline $\begin{array}{l}\text { Hvis ja til anden uddannelse, ople- } \\
\text { ver du så at kunne bruge denne i dit } \\
\text { pædagogiske arbejde }\end{array}$ & $\begin{array}{l}\text { Ja } \\
\text { Antal i \% }\end{array}$ & $\begin{array}{l}\text { Nej } \\
\text { Antal i \% }\end{array}$ & $\begin{array}{l}\text { Ved ikke } \\
\text { Antal i \% }\end{array}$ \\
\hline Alle $N=99$ & 68 & 24 & 8 \\
\hline Pædagoger $N=63$ & 71 & 24 & 5 \\
\hline Omsorgsmedhjælpere $N=34$ & 62 & 23 & 15 \\
\hline
\end{tabular}

Tabel 30. Er du under uddannelse

\begin{tabular}{|l|l|l|}
\hline Er du under uddannelse? & $\begin{array}{l}\text { Ja } \\
\text { Antal i \% }\end{array}$ & $\begin{array}{l}\text { Nej } \\
\text { Antal i \% }\end{array}$ \\
\hline Alle $\mathrm{N}=197$ & 15 & 85 \\
\hline Pædagoger $\mathrm{N}=135$ & 8 & 92 \\
\hline Omsorgsmedhjælpere $\mathrm{N}=61$ & 31 & 69 \\
\hline
\end{tabular}


Tabel 30A. Hvis 'ja' til at du er under uddannelse, hvilken type uddannelse?

\begin{tabular}{|c|c|c|}
\hline $\begin{array}{l}\text { Hvis 'ja' til at du er under uddan- } \\
\text { nelse, hvilken type uddannelse? }\end{array}$ & \begin{tabular}{|l} 
Ja \\
Faktisk antal \\
$(\mathrm{N}=)$
\end{tabular} & $\begin{array}{l}\text { Ja } \\
\text { Andel af de deltagende } \\
\text { medarbejdergrupperinger } \\
\mathrm{i} \%\end{array}$ \\
\hline \multicolumn{3}{|l|}{ Pædagogisk uddannelse } \\
\hline Alle & 16 & 7 \\
\hline Pædagoger & 4 & 2 \\
\hline Omsorgsmedhjælpere & 12 & 18 \\
\hline \multicolumn{3}{|c|}{ Mellemlang videregående uddannelse (eks. sygeplejerske) } \\
\hline Alle & 5 & 2 \\
\hline Pædagoger & 1 & 1 \\
\hline Omsorgsmedhjælpere & 4 & 6 \\
\hline \multicolumn{3}{|c|}{ Lang videregående uddannelse (eks. universitetsuddannelse) } \\
\hline Alle & 10 & 4 \\
\hline Pædagoger & 3 & 2 \\
\hline Omsorgsmedhjælpere & 7 & 11 \\
\hline \multicolumn{3}{|l|}{ Handels-/ kontor-/ serviceuddannelse } \\
\hline Alle & 1 & 1 \\
\hline Pædagoger & 0 & 0 \\
\hline Omsorgsmedhjælpere & 1 & 2 \\
\hline \multicolumn{3}{|l|}{ Håndværkeruddannelse } \\
\hline Alle & 10 & 4 \\
\hline Pædagoger & 3 & 2 \\
\hline Omsorgsmedhjælpere & 7 & 11 \\
\hline \multicolumn{3}{|l|}{ Anden uddannelse, hvilken: } \\
\hline Alle & 5 & 2 \\
\hline Pædagoger & 4 & 2 \\
\hline Omsorgsmedhjælpere & 1 & 2 \\
\hline
\end{tabular}

Tabel 31. Kurser/efteruddannelse inden for det pædagogiske område

\begin{tabular}{|l|l|l|}
\hline $\begin{array}{l}\text { Har du deltaget i kur- } \\
\text { ser/ efteruddannelse inden for det } \\
\text { pædagogiske område? }\end{array}$ & $\begin{array}{l}\text { Ja } \\
\text { Antal i \% }\end{array}$ & $\begin{array}{l}\text { Nej } \\
\text { Antal i \% }\end{array}$ \\
\hline Alle $\mathrm{N}=224$ & 75 & 25 \\
\hline Pædagoger $\mathrm{N}=163$ & 82 & 18 \\
\hline Omsorgsmedhjælpere $\mathrm{N}=59$ & 56 & 44 \\
\hline
\end{tabular}


Tabel 31A. Hvis 'ja' til kurser/efteruddannelse på det pædagogiske område, da hvilke?

\begin{tabular}{|l|l|l|}
\hline Eksterne kurser: & $\begin{array}{l}\text { Ja } \\
\text { Faktisk } \\
(\mathrm{N}=)\end{array}$ & $\begin{array}{l}\text { Ja } \\
\text { Andel af de deltagende } \\
\text { medarbejdergrupperinger } \\
\text { i \% }\end{array}$ \\
\hline 3-ugers AMU-kursus & 21 & 9 \\
\hline Alle & 17 & 10 \\
\hline Pædagoger & 4 & 6 \\
\hline Omsorgsmedhjælpere & \multicolumn{2}{|l|}{} \\
\hline Andet/ andre AMU-kurser & 42 & 17 \\
\hline Alle & 35 & 20 \\
\hline Pædagoger & 7 & 11 \\
\hline Omsorgsmedhjælpere & \multicolumn{2}{|l|}{} \\
\hline Andre eksterne pædagogiske kurser, da hvilke:* & 35 \\
\hline Alle & 85 & 39 \\
\hline Pædagoger & 69 & 24 \\
\hline Omsorgsmedhjælpere & 16 & 6 \\
\hline Længerevarende efter-/ videreuddannelse (f.eks. Diplom eller Master) \\
\hline Alle & 15 & 8 \\
\hline Pædagoger & 14 & 2 \\
\hline Omsorgsmedhjælpere & 1 & \\
\hline
\end{tabular}

* Blandt 'Andre eksterne pædagogiske kurser' nævnes psykiatri, introduktionskursus, personlig udvikling, demens, sikkerhed, førstehjælp, edb, magtanvendelseskursus, neuropædagogik, epilepsi, anerkendende relationer, Kbh. kommunes intro kursus, etisk kodeks, pædagogik ikke magt.

\begin{tabular}{|l|l|l|}
\hline Interne kurser: & $\begin{array}{l}\text { Ja } \\
\text { Faktisk antal } \\
(\mathrm{N}=)\end{array}$ & $\begin{array}{l}\text { Ja } \\
\text { Andel af de deltagende } \\
\text { medarbejdergrupperinger } \\
\text { i \% }\end{array}$ \\
\hline Faglige kurser & 123 & 51 \\
\hline Alle & 103 & 59 \\
\hline Pædagoger & 20 & 30 \\
\hline Omsorgsmedhælpere & 98 & 41 \\
\hline Organisatorisk/ samarbejde/ arbej & dsmiljø eller lignende kursus \\
\hline Alle & 98 & 44 \\
\hline Pædagoger & 78 & 30 \\
\hline Omsorgsmedhælpere & 20 & \\
\hline Andre interne kurser, da hvilke: * & 60 & 28 \\
\hline Alle & 69 & 29 \\
\hline Pædagoger & 11 & 17 \\
\hline Omsorgsmedhjælpere &
\end{tabular}

* Blandt 'Andre interne kurser' nævnes medicingivning, hygiejne, PC, samarbejde, kommunikation, forflytninger, værdigrundlag, førstehjælp, neuropædagogik, konfliktløsning, teamarbejde, praktikvejlederuddannelse 
Tabel 31B. Hvis 'ja' til kurser på det pædagogiske område, hvor mange og hvor mange timer (cirka) inden for det sidste år?

Hvor mange eksterne kurser har du haft på det pædagogiske område inden for det sidste år?

\begin{tabular}{|l|l|l|l|}
\hline $\begin{array}{l}\text { Antal eksterne } \\
\text { kurser }\end{array}$ & $\begin{array}{l}\text { Antal pædagoger } \\
\mathbf{i} \% \\
\mathrm{~N}=63\end{array}$ & $\begin{array}{l}\text { Antal omsorgs- } \\
\text { medhjælpere i \% } \\
\mathrm{N}=14\end{array}$ & $\begin{array}{l}\text { Alle } \\
\mathrm{N}=77\end{array}$ \\
\hline 1 & 62 & 57 & 61 \\
\hline 2 & 28 & 7 & 25 \\
\hline 3 & 4 & 22 & 8 \\
\hline 4 & 2 & 0 & 1 \\
\hline 5 & 2 & 7 & 3 \\
\hline 6 & 2 & 0 & 1 \\
\hline 7 & 0 & 0 & 0 \\
\hline 8 & 0 & 7 & 1 \\
\hline
\end{tabular}

Samlet antal timer du har haft på eksterne kurser på det pædagogiske område inden for det sidste år?

\begin{tabular}{|l|l|l|}
\hline $\begin{array}{l}\text { Antal timer i alt på eks- } \\
\text { terne kurser }\end{array}$ & $\begin{array}{l}\text { Antal pædagoger } \\
\mathbf{i} \% \\
\mathrm{~N}=53\end{array}$ & $\begin{array}{l}\text { Antal omsorgsmed- } \\
\text { hjælpere i \% } \\
\mathrm{N}=10\end{array}$ \\
\hline $1-8$ & 2 & 0 \\
\hline $9-16$ & 24 & 20 \\
\hline $17-24$ & 11 & 10 \\
\hline $25-32$ & 6 & 10 \\
\hline $33-40$ & 15 & 20 \\
\hline $41-48$ & 9 & 10 \\
\hline $49-56$ & 2 & 10 \\
\hline $57-64$ & 0 & 10 \\
\hline $65-72$ & 9 & 0 \\
\hline $73-80$ & 4 & 0 \\
\hline $81-88$ & 2 & 0 \\
\hline $89-96$ & 4 & 0 \\
\hline $97-104$ & 2 & 0 \\
\hline $105-$ & 10 & 10 \\
\hline
\end{tabular}

Hvor mange interne kurser har du haft på det pædagogiske område inden for det sidste år?

\begin{tabular}{|l|l|l|}
\hline Antal interne kurser & $\begin{array}{l}\text { Antal pædagoger } \\
\mathbf{i} \% \\
\mathrm{~N}=70\end{array}$ & $\begin{array}{l}\text { Antal omsorgsmed- } \\
\text { hjælpere i \% } \\
\text { N=11 }\end{array}$ \\
\hline 1 & 50 & 55 \\
\hline 2 & 29 & 18 \\
\hline 3 & 10 & 18 \\
\hline 4 & 6 & 0 \\
\hline 5 & 0 & 9 \\
\hline 6 & 0 & 0 \\
\hline 7 & 2 & 0 \\
\hline 8 & 1 & 0 \\
\hline 9 & 0 & 0 \\
\hline 10 & 1 & 0 \\
\hline Over 10 & 1 & 0 \\
\hline
\end{tabular}


Samlet antal timer du har haft på interne kurser på det pædagogiske område inden for det sidste år?

\begin{tabular}{|l|l|l|}
\hline $\begin{array}{l}\text { Antal timer i alt på in- } \\
\text { terne kurser }\end{array}$ & $\begin{array}{l}\text { Antal pædagoger } \\
\mathbf{i} \% \\
\mathrm{~N}=63\end{array}$ & $\begin{array}{l}\text { Antal omsorgsmed- } \\
\text { hjælpere i \% } \\
\mathrm{N}=9\end{array}$ \\
\hline $1-8$ & 14 & 11 \\
\hline $9-16$ & 38 & 56 \\
\hline $17-24$ & 13 & 0 \\
\hline $25-32$ & 9 & 0 \\
\hline $33-40$ & 6 & 11 \\
\hline $41-48$ & 0 & 11 \\
\hline $49-56$ & 2 & 11 \\
\hline $57-64$ & 6 & 0 \\
\hline $65-72$ & 3 & 0 \\
\hline $73-80$ & 3 & 0 \\
\hline $81-88$ & 0 & 0 \\
\hline $89-96$ & 2 & 0 \\
\hline $97-104$ & 2 & 0 \\
\hline $105-$ & 2 & 0 \\
\hline
\end{tabular}

Tabel 32. Arbejdserfaringer inden nuværende job?

\begin{tabular}{|l|l|l|}
\hline $\begin{array}{l}\text { Har du haft andre arbejdserfarin- } \\
\text { ger/ job efter afsluttet sko- } \\
\text { le/ uddannelse, som ligger før dit } \\
\text { nuværende job? }\end{array}$ & $\begin{array}{l}\text { Nej } \\
\text { Antal i \% } \\
\text { Antal i \% }\end{array}$ \\
\hline Alle $\mathrm{N}=233$ & 88 & 12 \\
\hline Omsorgogmer $\mathrm{N}=168$ & 89 & 11 \\
\hline
\end{tabular}


Tabel 32A. Hvis 'ja' til arbejdserfaringer, er det erfaringer fra det pædagogiske/omsorgsmæssige område?

\begin{tabular}{|c|c|c|}
\hline $\begin{array}{l}\text { Hvis 'ja' til arbejdserfaringer, er } \\
\text { det erfaringer fra det pædagogi- } \\
\text { ske/ omsorgsmæssige område? }\end{array}$ & $\begin{array}{l}\text { Ja } \\
\text { Antal i \% }\end{array}$ & $\begin{array}{l}\text { Nej } \\
\text { Antal i \% }\end{array}$ \\
\hline \multicolumn{3}{|c|}{$\begin{array}{l}\text { Har du arbejdserfaringer som omsorgsmedhjælper, pædagog, mv. i for- } \\
\text { hold til voksne med udviklingshæmning og/ eller fysisk handicappede }\end{array}$} \\
\hline Alle $\mathrm{N}=183$ & 73 & 27 \\
\hline Pædagoger $\mathrm{N}=130$ & 77 & 23 \\
\hline Omsorgsmedhjælpere $\mathrm{N}=51$ & 61 & 39 \\
\hline \multicolumn{3}{|c|}{ Har du arbejdserfaringer fra ældreplejen } \\
\hline Alle $\mathrm{N}=142$ & 48 & 52 \\
\hline Pædagoger $\mathrm{N}=97$ & 48 & 52 \\
\hline Omsorgsmedhjælpere $\mathrm{N}=43$ & 47 & 53 \\
\hline \multicolumn{3}{|c|}{ Har du arbejdserfaringer fra sfo/ fritidshjem } \\
\hline Alle $\mathrm{N}=140$ & 50 & 50 \\
\hline Pædagoger $\mathrm{N}=102$ & 57 & 43 \\
\hline Omsorgsmedhjælpere $\mathrm{N}=36$ & 33 & 67 \\
\hline \multicolumn{3}{|c|}{$\begin{array}{l}\text { Har du arbejdserfaringer fra daginstitution (vuggestue, børnehave eller } \\
\text { lign.) }\end{array}$} \\
\hline Alle $\mathrm{N}=160$ & 82 & 18 \\
\hline Pædagoger $\mathrm{N}=114$ & 87 & 13 \\
\hline Omsorgsmedhjælpere $\mathrm{N}=44$ & 68 & 32 \\
\hline \multicolumn{3}{|l|}{ Andre erfaringer: da hvilke? $*$} \\
\hline Alle $\mathrm{N}=77$ & 94 & 6 \\
\hline Pædagoger $\mathrm{N}=55$ & 93 & 7 \\
\hline Omsorgsmedhjælpere $\mathrm{N}=22$ & 95 & 5 \\
\hline
\end{tabular}

* Blandt 'Andre erfaringer' nævnes sygehjælper, klub, lærer, undervisning, vikar i børnehave, kunst/teater mm. Industri og hotel, kontor og hulledame, bh. Klasse. Uddannet inden for tøjbranchen, narkomaner, alkoholikere og anbragte børn, handicapmedhjælper, master uddannelse i pædagogik, pige i huset, butiksarbejde, arbejde med voksne skizofrene, borderline, misbrugere, spiseforstyrrelser.

Tabel 33. Hvor lang tid har du alt i alt været ansat inden for området i voksne med udviklingshæmning og/eller fysisk handicap?

\begin{tabular}{|l|l|l|}
\hline $\begin{array}{l}\text { Ansættelse inden for området i } \\
\text { antal år }\end{array}$ & $\begin{array}{l}\text { Pædagoger } \\
\text { Antal i \% }\end{array}$ & $\begin{array}{l}\text { Omsorgsmed- } \\
\text { hjælpere } \\
\text { Antal i \% }\end{array}$ \\
\hline 1 ar & 11 & 21 \\
\hline 2 ar & 7 & 14 \\
\hline 3 ar & 7 & 15 \\
\hline 4 ar & 6 & 6 \\
\hline 5 ar & 4 & 8 \\
\hline 6 ar & 3 & 7 \\
\hline 7 ar & 4 & 6 \\
\hline 8 ar & 4 & 6 \\
\hline 9 ar & 5 & 4 \\
\hline 10 ar & 5 & 2 \\
\hline Over 10 til og med 15 & 15 & 3 \\
\hline Over 15 til og med 20 & 7 & 1 \\
\hline Over 20 til og med 25 & 7 & 2 \\
\hline Over 25 til og med 30 & 6 & 5 \\
\hline Over 30 til og med 35 & 3 & 0 \\
\hline Over 35 til og med 40 & 2 & 0 \\
\hline
\end{tabular}


Tabel 33A. Halvdelen af pædagogerne har mere end 9 års arbejdserfaringer inden for området, heraf har en fjerdedel mere end 15 års erfaring inden for området. Godt hver fjerde omsorgsmedhjælper har mere end 7 års erfaring inden for området.

\begin{tabular}{|l|l|}
\hline $\begin{array}{l}\text { Samlet længde af ansættelse inden for } \\
\text { området voksne udviklingshæmmede } \\
\text { og/ eller fysisk handicappede (antal år) } \\
\mathrm{N}=212\end{array}$ & $\begin{array}{l}\text { Alle } \\
\text { Antal i \% }\end{array}$ \\
\hline Under 3 år & 19 \\
\hline Fra 3 ar til under 5 år & 16 \\
\hline Fra 5 år til under 10 ar & 26 \\
\hline Fra 10 år til under 15 år & 13 \\
\hline Fra 15 år til under år 20 år & 7 \\
\hline Fra 20 år og opefter & 20 \\
\hline
\end{tabular}




\section{Fremtidsforventninger}

Tabel 34. Ønske om personlig forandring i jobbet?

\begin{tabular}{|l|l|l|}
\hline $\begin{array}{l}\text { Har du inden for det seneste år } \\
\text { overvejet at finde et andet arbejde } \\
\text { eller søge en uddannelse? }\end{array}$ & $\begin{array}{l}\text { Ja } \\
\text { Antal i \% }\end{array}$ & $\begin{array}{l}\text { Nej } \\
\text { Antal i \% }\end{array}$ \\
\hline Alle $\mathrm{N}=236$ & 58 & 42 \\
\hline Pædagoger $\mathrm{N}=170$ & 55 & 45 \\
\hline Omsorgsmedhjælpere $\mathrm{N}=64$ & 64 & 36 \\
\hline
\end{tabular}

Tabel 34A. De vigtigste grunde til at overveje andet arbejde eller søge en uddannelse

* Hvis 'ja' til du har overvejet at finde et andet arbejde eller søge uddannelse. Hvad er da de $\mathbf{2}$ vigtigste grunde hertil?

\begin{tabular}{|l|l|}
\hline $\begin{array}{l}\text { De to vigtigste grunde til at over- } \\
\text { veje andet arbejde eller søge en } \\
\text { uddannelse }\end{array}$ & $\begin{array}{l}\text { Alle } \\
\text { Antal i \% }\end{array}$ \\
\hline For at få bedre arbejdstider & 9 \\
\hline $\begin{array}{l}\text { Ønske om nye udfordringer eller prø- } \\
\text { ve noget nyt }\end{array}$ & 28 \\
\hline Fordi arbejdet er for anstrengende & 8 \\
\hline Fordi arbejdet er for kedeligt & 4 \\
\hline $\begin{array}{l}\text { Fordi jeg oplever for lidt arbejds- } \\
\text { mæssig anerkendelse i offentligheden }\end{array}$ & 8 \\
\hline $\begin{array}{l}\text { Fordi jeg oplever for lidt arbejds- } \\
\text { mæssig anerkendelse intern }\end{array}$ & 8 \\
\hline $\begin{array}{l}\text { Pga. for mange konflikter og dårligt } \\
\text { arbejdsklima på arbejdspladsen }\end{array}$ & 10 \\
\hline Af hensyn til helbredet & 4 \\
\hline Af hensyn til familien & 4 \\
\hline Manglende tryghed i ansættelsen & 1 \\
\hline $\begin{array}{l}\text { For at påbegynde Pædagogisk Assi- } \\
\text { stent Uddannelse (tidligere PGU) }\end{array}$ & 0 \\
\hline $\begin{array}{l}\text { For at påbegynde pædagoguddannel- } \\
\text { sen }\end{array}$ & 3 \\
\hline For at påbegynde anden uddannelse. & 6 \\
\hline For at færdiggøre uddannelse & 2 \\
\hline Andet: (skriv evt. hvad) $*$ & 5 \\
\hline
\end{tabular}

* Kommentarer under 'Andet': Bedre løn, finde mere studierelevant arbejde 
Tabel 35. Forventninger til fremtiden. Hvad tror du, at du laver om tre år?

\begin{tabular}{|l|l|}
\hline $\begin{array}{l}\text { Forventninger til fremtiden. Hvad tror du, at du laver } \\
\text { om tre år? (del A besvares af pædagoger og del B } \\
\text { af omsorgsmedhjælpere) }\end{array}$ & $\begin{array}{l}\text { Antal pædagoger i \% } \\
\mathrm{N}=155\end{array}$ \\
\hline 35A. Pædagoger: & 46 \\
\hline Jeg arbejder på min nuværende arbejdsplads & 26 \\
\hline $\begin{array}{l}\text { Jeg arbejder inden for arbejdsområdet, men et andet } \\
\text { sted }\end{array}$ & 6 \\
\hline Jeg er under videreuddannelse & 6 \\
\hline Jeg har andet arbejde & 2 \\
\hline Jeg er på barsel & 8 \\
\hline Jeg er på efterløn eller pension & 6 \\
\hline Jeg laver noget helt andet & \multicolumn{2}{|l|}{} \\
\hline
\end{tabular}

\begin{tabular}{|c|c|}
\hline & $\begin{array}{l}\text { Antal omsorgsmed- } \\
\text { hjælpere i \% } \\
N=59\end{array}$ \\
\hline \multicolumn{2}{|l|}{ 35B. Omsorgsmedhjælpere: } \\
\hline Jeg arbejder på min nuværende arbejdsplads & 39 \\
\hline $\begin{array}{l}\text { Jeg arbejder inden for arbejdsområdet, men et andet } \\
\text { sted }\end{array}$ & 10 \\
\hline Jeg går på professionshøjskole for at blive pædagog & 10 \\
\hline $\begin{array}{l}\text { Jeg går på Pædagogisk Assistent Uddannelse (tidligere } \\
\text { PGU) }\end{array}$ & 0 \\
\hline Jeg er under anden uddannelse & 10 \\
\hline Jeg har andet arbejde & 22 \\
\hline Jeg er på barsel & 0 \\
\hline Jeg er på efterløn eller pension & 0 \\
\hline Jeg laver noget helt andet & 9 \\
\hline
\end{tabular}

Eventuel kommentar til spørgsmål undervejs eller spørgeskemaet som helhed: 17 pædagoger og 4 0msorgsmedhjælpere svarer og blandt dem er at skemaet ikke rettet mod $\S 85$ arbejde (private hjem), at der savnes spørgsmål, der tager hensyn til de tungeste brugere, at man er glad for arbejdet trods al den presse der har været omkring institutionen, og at mange af de svære ting er ikke bostedets ansvar/skyld, men for få normeringer set $\mathrm{i}$ forhold til de mange krav. 